\title{
COAL: ENERGY FOR THE FUTURE
}

\author{
Committee on the Strategic Assessment \\ of the \\ U.S. Department of Energy's Coal Program
}

Board on Energy and Environmental Systems Commission on Engineering and Technical Systems

-National Research Council

\begin{abstract}
DISCLAIMER
This report was prepared as an account of work sponsored by an agency of the United States Government. Neither the United States Government nor any agency thereof, nor any of their employees, makes any warranty, express or implied, or assumes any legal liability or responsibility for the accuracy, completeness, or usefulness of any information, apparatus, product, or process disclosed, or represents that its use would not infringe privately owned rights. Reference herein to any specific commercial product, process, or service by trade name, trademark, manufacturer, or otherwise does not necessarily constitute or imply its endorsement, recommendation, or favoring by the United States Government or any agency thereof. The views and opinions of authors expressed herein do not necessarily state or reflect those of the United States Government or any agency thereof.
\end{abstract}

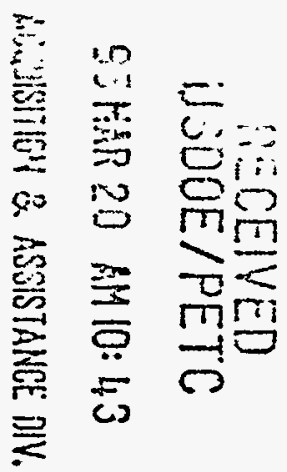


NOTICE: The project that is the subject of this report was approved by the Governing Board of the National Research Council, whose members are drawn from the councils of the National Academy of Sciences, the National Academy of Engineering, and the Institute of Medicine. The members of the committee responsible for the report were chosen for their special competences and with regard for appropriate balance.

This report has been reviewed by a group other than the authors according to procedures approved by a Report Review Committee consisting of members of the National Academy of Sciences, the National Academy of Engineering, and the Institute of Medicine.

The National Academy of Sciences is a private, nonprofit, self-perpetuating society of distinguished scholars engaged in scientific and engineering research, dedicated to the furtherance of science and technology and to their use for the general welfare. Upon the authority of the charter granted to it by the Congress in 1863, the Academy has a mandate that requires it to advise the federal government on scientific and technical matters. Dr. Bruce $\mathrm{M}$. Alberts is president of the National Academy of Sciences.

The National Academy of Engineering was established in 1964, under the charter of the National Academy of Sciences, as a parallel organization of outstanding engineers. It is autonomous in its administration and in the selection of its members, sharing with the National Academy of Sciences the responsibility for advising the federal government. The National Academy of Engineering also sponsors engineering programs aimed at meeting national needs, encourages education and research, and recognizes the superior achievements of engineers. Dr. Robert $M$. White is president of the National Academy of Engineering.

The Institute of Medicine was established in 1970 by the National Academy of Sciences to secure the services of eminent members of appropriate professions in the examination of policy matters pertaining to the health of the public. The Institute acts under the responsibility given to the National Academy of Sciences by its congressional charter to be an adviser to the federal government and, upon its own initiative, to identify issues of medical care, research, and education. Dr. Kenneth I. Shine is president of the Institute of Medicine.

The National Research Council was organized by the National Academy of Sciences in 1916 to associate the broad community of science and technology with the Academy's purposes of furthering knowledge and advising the federal government. Functioning in accordance with general policies determined by the Academy, the Council has become the principal operating agency of both the National Academy of Sciences and the National Academy of Engineering in providing services to the government, the public, and the scientific and engineering communities. The Council is administered jointly by both Academies and the Institute of Medicine. Dr. Bruce M. Alberts and Dr. Robert M. White are chairman and vice chairman, respectively, of the National Research Council.

This report and the study on which it is based were supported by Grant No. DE-FG22-93PC93035 from the U.S. Department of Energy.

Library of Congress Cataloging-in-Publication Data (to come)

Printed in the United States of America 


\section{DISCLAIMER}

Portions of this document may be illegible in electronic image products. Images are produced from the best available original document. 


\section{COMMITTEE ON THE STRATEGIC ASSESSMENT OF THE U.S. DEPARTMENT OF ENERGY'S COAL PROGRAM*}

JOHN P. LONGWELL, Chair, Professor Emeritus, Department of Chemical Engineering, Massachusetts Institute of Technology, Cambridge

EDWARD S. RUBIN, Vice-Chair, Professor, Mechanical Engineering and Public Policy, and Director, Center for Energy and Environmental Studies, Carnegie Mellon University, Pittsburgh, Pennsylvania

MORREL H. COHEN, Senior Scientific Advisor, Corporate Research Science Laboratories, Exxon Research and Engineering Company, Annandale, New Jersey

A. DENNY ELLERMAN, Executive Director, Center for Energy and Environmental Policy, Massachusetts Institute of Technology, Cambridge

ROBERT D. HALL, General Manager, Alternative Feedstock Development Department, Amoco Corporation, Naperville, Illinois

JOHN W. LARSEN, Professor, Department of Chemistry, Lehigh University, Bethlehem, Pennsylvania

PETER T. LUCKIE, Associate Dean for Research, College of Earth and Mineral Sciences, The Pennsylvania State University, University Park

MAURICE D. McINTOSH, Vice President, Fossil/Hydro Generation, Duke Power Company, Charlotte, North Carolina

GEORGE T. PRESTON, Vice President, Generation, Electric Power Research Institute, Palo Alto, California

ERIC H. REICHL, Consultant, Princeton, New Jersey

LARRY D. WOODFORK, Director and State Geologist, West Virginia Geological and Economic Survey, Morgantown, West Virginia

JOHN M. WOOTTEN, Vice President, Engineering and Environmental Services, Peabody Holding Company, Inc., St. Louis, Missouri

Liaisons from the Board on Energy and Environmental Systems

LARRY PAPAY, Vice President and Manager of Research and Development, Bechtel Group, Inc., San Francisco, California

HAROLD H. SCHOBERT, Chairman, Fuel Sciences Program, Department of Materials Science and Engineering, The Pennsylvania State University, University Park

Project Staff

MAHADEVAN MANI, Director

JAMES ZUCCHETTO, Senior Program Officer

JILL WILSON, Study Director

WENDY ORR, Project Assistant

ANN COVALT, Consulting Editor

*Martha W. Gilliland, Vice Provost for Academic Affairs, University of Arizona, Tucson, served on the committee from October 1993 through April 1994. 


\section{BOARD ON ENERGY AND ENVIRONMENTAL SYSTEMS}

H. M. (HUB) HUBBARD, Chair, President and Chief Executive Officer, Pacific International Center for High Technology Research (PICHTR), Honolulu, Hawaii

RICHARD A. MESERVE, Vice-Chair, Partner, Covington \& Burling, Washington, D.C.

STEPHEN D. BAN, President and Chief Executive Officer, Gas Research Institute, Chicago, Illinois

ROBERT D. BANKS, Program Director, Technology and Environment, World Resources Institute, Washington, D.C.

ALLEN J. BARD, Department of Chemistry, University of Texas at Austin .

BARBARA R. BARKOVICH, Partner, Barkovich and Yap, Consultants, San Rafael, California JAN BEYEA, Chief Scientist, National Audubon Society, New York, New York

DAVID E. DANIEL, L.B. (Preach) Meaders Professor of Civil Engineering, Department of Civil Engineering, University of Texas at Austin

LINDA C. DOLAN, Staff Environmental Officer, Martin Marietta, Electronics and Missiles, Orlando, Florida

FRANCOIS HEUZE, Head, Geotechnical Programs, Lawrence Livermore National Laboratory, Livermore, California

ROBERT L. HIRSCH, Consultant, Washington, D.C.

CHARLES D. KOLSTAD, Professor, Department of Economics, University of California-Santa Barbara

JANE C.S. LONG, Staff Scientist, Earth Sciences Division, Lawrence Berkeley Laboratory, Berkeley, California

S. L. (CY) MEISEL, Vice President, Research (Retired), Mobil R\&D Corporation, Princeton, New Jersey

SHLOMO NEUMAN, Regent's Professor, Hydrology and Water Resources, University of Arizona, Tuscon

THOMAS D. O'ROURKE, Professor, Civil and Environmental Engineering, Cornell University, Ithaca, New York

LARRY T. PAPAY, Vice President and Manager of Research and Development, Bechtel Group, Inc., San Francisco, California

RUTH A. RECK, Director, Global Climate Change Program, Argonne National Laboratory, Argonne, Illinois

MARC H. ROSS, Professor, Physics Department, University of Michigan, Ann Arbor

HAROLD H. SCHOBERT, Chairman, Fuel Sciences Program, Department of Materials Science and Engineering, The Pennsylvania State University, University Park

JOEL SPIRA, Chairman and Director of Research, Lutron Electronics Co., Inc., Coopersburg, Pennsylvania

JON M. VEIGEL, President, Oak Ridge Associated Universities, Oak Ridge, Tennessee 
Liaisons for the Commission on Engineering and Technical Systems

JOHN A. TILLINGHAST, President, Tiltec, Portsmouth, New Hampshire

JOHN B. WACHTMAN, JR., Sosman Professor of Ceramics, Rutgers University, Piscataway, New Jersey

Board on Energy and Environmental Systems Staff

SUSANNA CLARENDON, Administrative Assistant

THERON FEIST, Project Assistant

HELEN JOHNSON, Administrative Associate

MAHADEVAN MANI, Director

AMELIA MATHIS, Project Assistant

WENDY ORR, Project Assistant

JILL WILSON, Program Officer

TRACY WILSON, Senior Program Officer

JAMES ZUCCHETTO, Senior Program Officer 


\section{Preface}

This report was prepared in response to a request by the U.S. Department of Energy (DOE). The principal objectives of the study were to assess the current DOE coal program vis-à- " vis the provisions of the Energy Policy Act of 1992 (EPACT), and to recommend the emphasis and priorities that DOE should consider in updating its strategic plan for coal.

A strategic plan for research, development, demonstration, and commercialization (RDD\&C) activities for coal should be based on assumptions regarding the future supply and price of competing energy sources, the demand for products manufactured from these sources, technological opportunities, and the need to control the environmental impact of waste streams. These factors change with time. Accordingly, the committee generated strategic planning scenarios for three time periods: near-term, 1995-2005; mid-term, 2006-2020; and, long-term, 2021-2040.

It was assumed that coal would not be resource limited during these time periods. Supplies of domestic natural gas were taken to be adequate for current uses, although prices will likely increase because of increased finding and production costs. Imported oil also was assumed to be available at a price that is likely to be more uncertain and that will probably increase faster than that of coal. The committee also assumed that the required level of control of all waste streams from coal systems would increase with time. In particular, the issue of global warming is expected to provide a powerful driving force for improvement in the conversion efficiency of coal to electric power and clean gaseous and liquid fuels.

The most appropriate role for DOE in developing cost competitive, environmentally acceptable coal technologies, as required by EPACT, is strongly dependent on the needs and opportunities for technological advancement in the near-, mid-, and long-term periods and on domestic and foreign RDD\&C programs outside DOE. Comparison of DOE programs and plans with these other activities, with the committee's strategic planning scenarios, and with the goals set by EPACT forms the basis for the committee's recommendations.

At the first committee meeting in November 1993 and at the meetings of the power generation and fuels subgroup and the strategy and policy subgroup, both in January 1994, presentations from DOE staff and others provided an essential information base. Two further committee meetings in March and May 1994, together with a writing group meeting in April attended by John Longwell, Edward Rubin, Robert Hall, George Preston, John Wootten, Harold Schobert, and National Research Council staff, permitted the committee to develop and refine its conclusions and recommendations and to assemble a full draft of the report. The rapid pace at which this complex task was completed called for a high level of participation by committee 
members and for vigorous and pro-active involvement by the National Research Council program officers, Dr. Jill Wilson and Dr. James Zucchetto, and the project assistant, Ms. Wendy Orr. These contributions, together with those of the many DOE staff members who provided advice and consultation, were noteworthy and highly appreciated.

JOHN P. LONGWELL, Chair Committee on the Strategic Assessment of the Department of Energy's Coal Program 
- 


\section{Contents}

$\begin{array}{lr}\text { EXECUTIVE SUMMARY } & 1\end{array}$

The DOE Coal Program, 2

Strategic Planning, 3

Power Generation, 5

Clean Fuels from Coal, 9

Systems Analysis, 11

EPACT, 12

References, 13

$\begin{array}{ll}\text { Part I Strategic Planning for Coal } & 14\end{array}$

1 INTRODUCTION AND SCOPE OF THE STUDY - 15

The Energy Policy Act of 1992, 16

Study Scope and Objectives, 16

The Committee's Approach, 17

Coal Research and Development, 18

Organization of the Report, 19

References, 20

2 OVERVIEW OF U.S. DEPARTMENT OF ENERGY PROGRAMS AND

PLANNING

Major Trends in the DOE Coal Program, 22

The DOE Coal Program Structure and Budget, 23

DOE's Strategic Planning, 25

Summary, 28

References, 28

3 TRENDS AND ISSUES FOR FUTURE COAL USE

Domestic and International Markets, 35

Coal Use for Domestic Electricity Generation, 38

Coal Use for Liquid and Gaseous Fuels, 45

Other Uses of Coal, 47 
Environmental Issues for Coal Use, 48

Summary, 51

References, 52

4 THE STRATEGIC PLANNING FRAMEWORK

Baseline Strategic Planning Scenarios, 66

Alternative Scenarios, 67

Scenario Implications for RDD\&C Planning, 68

Additional Criteria to Set National Coal RDD\&C Priorities, 69

References, 71

Part II Overview of Current DOE Coal Programs

5 COAL PREPARATION, COAL-LIQUID MIXTURES, AND COALBED

METHANE RECOVERY

Coal Preparation, 74

Coal-Liquid Mixtures, 79

Coalbed Methane Recovery, 81

References, 83

6 CLEAN FUELS AND SPECIALTY PRODUCTS FROM COAL

Gasification of Coal, 85

Products from Coal-Derived Gas, 91

Products from Direct Liquefaction and Pyrolysis of Coal, 96

Coal Refineries and Coproduct Systems, 100

Findings, 103

References, 105

7 ELECTRIC POWER GENERATION

Pulverized Coal Systems, 113

Fluidized-Bed Combustion, 117

Integrated Gasification Combined-Cycle Systems, 121

Integrated Gasification Fuel Cell Systems, 123

Magnetohydrodynamic Power Generation, 126

Combustion Turbines, 128

Emission Control Technologies, 131

References, 138

8 TECHNOLOGY DEMONSTRATION AND COMMERCIALIZATION

Commercialization Issues, 150

Clean Coal Technology Program, 151

Advanced Power Systems Demonstration Projects, 152 
Future Directions, 154

Advanced Fuel Systems Demonstration Projects, 155

Findings, 156

References, 157

9 ADVANCED RESEARCH PROGRAMS

Program Organization and Budgets, 160

The Role of Advanced Research, 161

Combustion and Gasification, 162

Coal Conversion and Catalysis, 163

Materials, 165

Findings, 170

References, 171

Part III Recommendations for DOE's Future Coal Program

10 CONCLUSIONS AND RECOMMENDATIONS

Strategic Planning for Coal, 176

Coal Preparation, Coal-Liquid Mixtures, and Coalbed Methane Recovery, 177

Electric Power Generation, 179

Clean Fuels and Specialty Products from Coal, 189

Systems Analysis and Strategy Studies, 196

Technology Demonstration and Commercialization, 197

Advanced Research Programs, 199

The Energy Policy Act of 1992 (EPACT), 200

References, 202

\section{APPENDIXES}

A Project Description, 218

B The Energy Policy Act of 1992, 222

C DOE Budget Data, 240

D Environmental Issues Affecting Coal Use, 245

E CCT Demonstration Projects, 254

F Committee Meetings and Activities, 261

G Biographical Sketches of Committee Members, 264 


\section{Executive Summary}

The outlook for coal use in the United States is governed by two major factors, namely, the desirability of using an abundant, low-cost, and secure domestic energy resource and the need to comply with increasingly stringent environmental control requirements. Over the time periods considered in this study (ranging from the present through 2040), the production cost of domestic coal is not expected to increase significantly. In contrast, rises in the cost of domestic natural gas are anticipated because of resource limitations. There are also likely to be significant increases in the price of imported petroleum (EIA, 1994). While continued growth in the use of renewable energy forms is expected, along with a potential resurgence in nuclear power, there will be a powerful economic driving force for major and expanded use of coal over the next several decades, with concomitant pressures to reduce environmental impacts through improved technologies. In addition, in countries of South Asia and the Pacific Rim, notably China, rapid economic growth coupled with substantial indigenous coal supplies will likely contribute significantly to an expected worldwide growth in coal utilization over the next 15 years or more (DOE, 1993a).

In this context the Energy Policy Act of 1992 (EPACT) directs the U.S. Department of Energy (DOE) to establish programs for developing environmentally acceptable coal-based technologies for a broad range of applications, notably electric power generation and the manufacture of liquid and gaseous fuels and nonfuel products, such as carbons and coal-derived chemicals. A number of the coal-related provisions of EPACT emphasize the need to ensure the availability of technologies for commercial use by 2010 , reflecting both anticipated requirements for coal-based power generation and a desire to capitalize on earlier federal research and development (R\&D) investment. This report of the National Research Council's (NRC) Committee on the Strategic Assessment of the U.S. Department of Energy's Coal Program addresses the future role of DOE in research, development, demonstration, and commercial application (RDD\&C) programs on coal-based technologies. In particular, the committee was asked to recommend, in broad strategic terms, the emphasis and priorities that DOE ought to consider in updating its coal program and responding to EPACT. The committee's major recommendations are given in this Executive Summary. Detailed conclusions and recommendations regarding DOE's coal program, and its relationship to EPACT, can be found in Chapter 10. Throughout the report, costs are based on utility financing, and fuel higher heating value (HHV) is used as the basis for energy efficiency figures (see Glossary). 


\section{THE DOE COAL PROGRAM}

Coal-related activities within DOE currently fall under two main budget categories: Fossil Energy (FE) R\&D and the Clean Coal Technology (CCT) program. The CCT program was initiated in 1986 and is scheduled to run through 2004, with the specific objective of demonstrating advanced coal technologies at a large enough scale for the marketplace to judge their commercial potential. All CCT projects involve cost sharing between DOE and industry, with the industrial partners contributing at least 50 percent of the cost of the technology demonstration, as well as playing a major role in project definition and in ensuring eventual commercialization. Five solicitation rounds (CCT-I through CCT-V) have been conducted, resulting in 45 active projects with total funding of $\$ 6.9$ billion, of which DOE is providing $\$ 2.4$ billion (34 percent). ${ }^{1}$

The congressionally mandated CCT program complements the FE R\&D program, which has been in existence since the inception of DOE and forms the continuing basis of DOE's coal program. The annual funding level for the FE R\&D program, which encompasses oil, natural gas, and coal, has remained relatively constant at the low- to mid- $\$ 400$ million level for fiscal year (FY) 1992 through FY 1994. However, the oil and natural gas budgets have grown at the expense of the coal budget, which was $\$ 167$ million in FY 1994, with a proposed reduction to $\$ 128$ million for FY 1995 . However, DOE also has proposed that the natural gas budget for fuel cell and gas turbine activities be increased from $\$ 74$ million in FY 1994 to $\$ 112$ million in FY 1995. These two programs are also integral components of advanced coal-based power systems. The FY 1995 budget proposal reflects an overall increase in the FE R\&D budget for advanced power generation technologies.

The coal portion of the FE R\&D program is divided into three major components: Advanced Clean Fuels, Advanced Clean/Efficient Power Systems, and Advanced Research and Technology Development. The Advanced Clean Fuels program aims to develop systems that can produce coal-derived transportation fuels, chemicals, and other products at costs competitive with oil-derived products when petroleum prices reach $\$ 25 /$ barrel (bbl) or greater in 1991 dollars. Total funding for this program has decreased significantly in recent years, from $\$ 59.6$ million in FY 1992 to $\$ 40.9$ million in FY 1994. The FY 1995 budget request of $\$ 20.1$ million reflects a proposed further decline in DOE activities in this area.

The Advanced Clean/Efficient Power Systems program supports the development of systems based on coal combustion or gasification that will become commercial in different time periods. Program goals for efficiency, levels of emissions, and energy cost to be achieved in $2000,2005,2010$, and 2015 have been established. Some technologies are funded under the FE coal R\&D advanced power systems activity, the FE natural gas R\&D program, and the CCT program. For example, subsystem and component testing, environmental and economic studies, and pilot plant tests for pressurized fluidized-bed combustion (PFBC) systems are funded under the FE coal R\&D program, while demonstrations of first- and second-generation PFBC systems will be conducted under CCT funding. These systems will employ advanced turbines developed in the natural gas $\mathrm{R} \& \mathrm{D}$ program. The advanced power systems program experienced a funding

\footnotetext{
'Throughout this report, all costs, prices, and so forth, are given in constant 1992 dollars unless otherwise specified. An exception is DOE budget data, which are quoted in current dollars.
} 
reduction from $\$ 187.1$ million in FY 1992 to $\$ 97.1$ million in FY 1994, but this decline is largely the result of completion of the magnetohydrodynamics proof-of-concept program and transfer of the fuel cells activity from the coal program to the natural gas program in FY 1994.

All DOE coal advanced research programs fall within the FE coal R\&D budget category, although they are not confined to the Advanced Research and Technology Development program. Advanced research on fuels and power generation is also funded under the Advanced Clean Fuels and Advanced Clean/Efficient Power Systems budget categories, respectively (see Chapter 9). The advanced research budget for coal declined about 30 percent in real terms between FY 1988 and FY 1994, with a further decrease of approximately 25 percent to $\$ 22.4$ million proposed for FY 1995.

\section{STRATEGIC PLANNING}

The development of a strategic plan for coal requires an understanding of the factors likely to influence coal use over the time horizon of interest. As a basis for developing a set of strategic planning scenarios, the committee reviewed markets for coal and coal utilization technologies, major coal uses-notably, electric power generation, the availability of competing energy sources, and the impact of existing and likely future environmental regulations affecting coal use.

The domestic coal resource base is abundant, constituting over 94 percent of proven U.S. fossil fuel reserves. Coal is not projected to be resource limited in the time period considered in this study (i.e., through 2040). U.S. coal prices have declined over the past decade, and no rapid price increases are anticipated in the near future. Imports of South American coals, which are competitive with U.S. coals on a delivered price basis in certain locations in the eastern United States, are likely to play a role in keeping domestic prices low. While U.S. coal exports are significant (10 percent of 1992 production of 998 million tons), technology developments within the DOE coal program are not likely to open any major new markets for U.S. coal. In contrast, demands for new and retrofit coal-based electricity generation technologies in developing countries, notably China and in Eastern Europe, represent a potentially large export market for U.S. technology. Nonetheless, the extent of U.S. participation in overseas markets for advanced coal utilization technologies is difficult to forecast, given the competition from overseas companies and the complex political and economic factors governing international trade.

The single largest use for coal in the United States is for power generation; electric utilities consumed 87.4 percent of the total 1992 domestic consumption of 892 million tons. However, the demand for new coal-fired power generating capacity in the United States is expected to remain low for the next 10 years. Overcapacity, while declining, still exists in some regions, and low-cost natural gas is more attractive than coal for the addition of peaking capacity since capital costs are lower and the lead time for plant construction is shorter.

A resurgence in demand for new coal-based generating capacity is anticipated by 2010 , as existing plants reach the end of their useful life and baseload electricity demand increases. Natural gas prices will likely increase by this time, to the point where a return to coal-based technologies is favored. However, increasingly stringent environmental regulations governing 
emissions of sulfur dioxide $\left(\mathrm{SO}_{2}\right)$, oxides of nitrogen $\left(\mathrm{NO}_{x}\right)$, fine-particulate air pollutants, and possibly air toxics from power plants, as well as solid waste issues, will place severe demands on coal-fired power plant performance. Furthermore, concern over the potential impacts of global warming may lead to penalties on carbon dioxide $\left(\mathrm{CO}_{2}\right)$ emissions from coal combustion, resulting in increased emphasis on high efficiency for coal-based power generation systems designed to operate through the middle of the twenty-first century.

The market for synthetic gaseous and liquid fuels from coal is currently small due to the widespread availability and low cost of petroleum and natural gas. This situation is expected to persist for the next 15 years, with increases in oil and gas prices unlikely to be large enough to stimulate major investment in processes for the manufacture of synthetic natural gas or liquid fuels from coal (EIA, 1994). However, by the second decade of the twenty-first century this situation may change, as the cost of synthetic fuels is reduced by process and systems advances and as concerns over the supply and price of competing fuels increase.

On the basis of the above factors influencing coal use, the committee developed a set of strategic planning scenarios summarizing requirements for future coal utilization to 2040 (see Chapter 4 and below). DOE's current strategic planning objectives extend through 2010, largely in response to the EPACT requirement to develop commercial technologies by that date. However, coal will continue to be a major source of energy well beyond 2010, with the potential in the longer term for a changing emphasis in coal use in response to resource limitations and increasing prices for competing fuels.

The committee recommends that the planning horizon for DOE coal RDD\&C programs extend beyond the agency's current planning horizon of 2010. The committee recommends the use of three time periods for strategic planning: near-term (1995-2005), mid-term (2006-2020), and long-term (2021-2040). The main objective of DOE's coal program in all periods should be to provide the basis for technological solutions to likely future demands, in a way that is robust and flexible.

The above timeframes correspond to anticipated major trends in coal utilization. In the near term the scenarios for coal use will resemble today's, with power generation persisting as the dominant market, despite limited demand for new coal-fired baseload generation capacity. The mid term will likely be a transition period. Power generation will remain the major use of coal, and there will be a significant demand for new baseload capacity using advanced highefficiency coal technologies to meet increasingly stringent air pollution control and solid waste disposal requirements, plus possible penalties for $\mathrm{CO}_{2}$ emissions. In addition, increasing international oil prices will result in a growth of interest in the production of synthetic transportation fuels from coal, and increases in natural gas prices will stimulate interest in coal gasification. Coproduct systems that manufacture two or more saleable products might provide attractive market-entry opportunities for liquid fuels from coal. For example, gasification technology could provide a common basis for both power generation and the production of liquid fuels.

In the long term (beyond 2020) the production of liquid and gaseous fuels from coal will likely become increasingly important. Although coal use for power generation will continue to be significant, increasingly stringent controls on emissions, particularly of greenhouse gases, will 
impose severe demands on efficiency and emission control systems, stimulating interest in alternative energy sources for power generation. Environmental concerns, including greenhouse issues, will also affect the production of clean fuels from coal. Nonetheless, the demand for these products is expected to grow once gas and petroleum resources dwindle or rise substantially in price. The committee recognizes that planning for the long-term period will necessarily be less well defined and will entail greater uncertainty than near- and mid-term planning.

These scenarios suggest a change in future priorities within the DOE coal program. As a consequence of the widespread availability of natural gas and petroleum, industry R\&D on technologies for producing clean fuels from coal is currently very modest in scope, apart from the development of coal gasification technologies for integrated gasification combined-cycle (IGCC) power generation systems. Thus, the committee saw DOE as uniquely able to play a leading role in maintaining and developing technological expertise in fuels production and positioning the United States to respond to potential demands for coal-based fuels in the mid to long term.

The committee recommends that within the DOE coal program there be an increasing emphasis on the production of clean fuels and other carbon-based products over time.

A further consequence of the committee's recommendation that the strategic planning scenario be extended beyond 2010 is the need to reassess the role and priorities of DOE's advanced research programs. As noted above, there has been a significant decrease in the advanced research budget since 1988. To some extent, this decline reflects the transition of advanced power generation systems from $R \& D$ to demonstration status. However, significant reductions have also occurred in funding for coal liquefaction and other advanced research areas. In the opinion of the committee, the DOE budget reductions for advanced research are not commensurate with the increasing needs for lower-cost, more efficient, and more environmentally acceptable use of coal through the next 50 years and beyond. The decline in DOE activities is all the more serious given the decreasing private sector investment in longrange research on coal-related technologies.

The committee recommends that increased resources be devoted to advanced research activities to support DOE's strategic objectives for coal, with emphasis on needs identified for mid- and long-term improvements in efficiency, emissions reduction, and cost for both power generation and fuels production.

\section{POWER GENERATION}

\section{Technology Development}

Research, development, and demonstration (RD\&D) of advanced power generation technologies is conducted under the Advanced Clean/Efficient Power Systems component of the 
FE coal R\&D program. DOE goals for efficiency, emissions, and cost have been established. Efficiencies are projected to rise from current new plant levels of 38 to 42 percent to 60 percent within the next two decades. A number of interim systems are proposed with target efficiencies of 45 to 55 percent. DOE's target for emissions of $\mathrm{SO}_{2}, \mathrm{NO}_{x}$, and particulates is one-tenth the 1979 federal New Source Performance Standards (NSPS) by 2010. An important feature of the DOE plan is to achieve the above efficiency improvements and emissions reductions at an overall cost of electricity generation that is 10 to 20 percent lower than today's coal-fired power plants. In the view of the committee these objectives, while laudatory, may be overly optimistic. In general, advanced technologies tend to perform less well and cost significantly more than originally envisioned as they move from concept to full-scale commercial operation (Merrow et al., 1981). In the case of technologically complex advanced power systems, the objective of achieving high efficiency and low emissions with a 10 to 20 percent reduction in the cost of electricity may be particularly challenging. A more realistic goal would be to achieve the proposed efficiency improvements at an overall cost comparable to current new coal plants.

The committee also notes that many of DOE's emission goals for 2000 to 2010 already can be met with current commercial emissions control technology, which many state and local governments now require. The expected trend toward increasingly stringent environmental regulations could demand emissions levels that are more stringent than the current DOE goals, thereby increasing plant costs. The committee concluded that DOE's power plant emissions goals are insufficiently challenging given the capabilities of current commercial technology and anticipated environmental demands on future coal use.

Despite reservations regarding program goals for the cost of electricity and the environmental emissions, the committee noted the important role of DOE's advanced power systems program in stimulating the development of new technologies to meet anticipated electricity demand early in the next century. Participation by DOE in technology development is particularly important given the reluctance of the utility industry to invest heavily in RD\&D of advanced coal-based technologies in today's increasingly competitive environment.

For the purposes of this study, the committee divided the advanced coal-based power generation technologies under development with DOE funding into three groups, based on target efficiencies and approximate dates for commercial availability:

- Group 1 technologies-low-emission boiler systems (LEBS), first-generation PFBC systems, and first-generation IGCC systems-have target efficiencies in the range of 40 to 42 percent and should be available around the year 2000 .

- Group 2 technologies-externally fired combined-cycle (EFCC) systems, secondgeneration PFBC systems, and second-generation IGCC systems-are projected to have efficiencies of approximately 45 percent and to be available no later than 2005 .

- Group 3 technologies-high-performance power system (HIPPS), advanced secondgeneration PFBC systems, integrated gasification advanced-cycle (IGAC) systems, and integrated gasification fuel cell (IGFC) systems-have projected efficiencies of 50 percent or greater and are expected to be available in the 2010 to 2015 time period.

Given the low projected demand for new coal-fired generating capacity prior to 2005, the U.S. market for Group 1 systems will likely be small. These systems are essentially based 
on proven components and do not offer an efficiency advantage over state-of-the-art pulverized coal systems. Projected performance and cost enhancements come from improved systems design and integration. There may be opportunities to market these technologies overseas, where demands for new coal-based power generation capacity are greatest. Despite their limited commercial potential, the first-generation PFBC and IGCC systems constitute important steps toward the development of higher-efficiency Group 2 and Group 3 systems. In contrast, the LEBS does not offer comparable growth potential, since it employs a simple steam (Rankine) cycle, whereas all of the Group 2 and Group 3 systems use combined cycles with potentially higher efficiencies.

The committee recommends that future investment of DOE resources in firstgeneration systems be based on realistic market expectations and value as an entry into new technology with high growth potential. At least $\mathbf{5 0}$ percent industry cost sharing should be required to demonstrate private sector confidence in these technologies.

Group 2 and Group 3 power generation systems depend on the successful development of several critical components, including high-temperature gas turbines, high-temperature heat exchangers, advanced high-temperature furnaces, fuel cells, hot gas cleanup technology, and high-efficiency gasification. The riskiest components appear to be the high-temperature ceramic heat exchanger required for the externally fired combined-cycle system and the hot gas cleanup systems required for advanced PFBC and needed for maximum-efficiency IGCC and IGFC systems. The $1370{ }^{\circ} \mathrm{C}$ to $1430{ }^{\circ} \mathrm{C}\left(2500^{\circ} \mathrm{F}\right.$ to $\left.2600{ }^{\circ} \mathrm{F}\right)$ gas turbine required for Group 3 systems is within the state of the art for aviation systems but requires further development, demonstration, and testing for power generation applications. Fuel cells hold significant promise for efficiency advantages, but their high cost may be a barrier to widespread use of IGFC systems.

Gas cleanup is necessary to comply with environmental requirements and to protect advanced gas turbines from corrosive impurities, notably chlorine, volatile alkali metals, and particulates. Commercially available cold gas cleanup technology could be used for IGCC and IGFC systems, although this would incur higher costs and an efficiency penalty of approximately 2 percentage points for air-blown second-generation systems. In contrast, advanced PFBC systems require hot gas filtration since cooling the high-temperature, high-pressure combustion products would eliminate the advantages of PFBC. Thus, IGCC is a somewhat less risky technology than PFBC. Environmentally, IGCC has the advantage of producing by-product sulfur or sulfuric acid, whereas the use of limestone or dolomite for in-bed sulfur capture in PFBC systems can as much as double the amount of solid waste compared with IGCC systems. As suggested above, IGCC is also less risky than indirectly fired cycles (EFCC and HIPPS), which require significant technological development of high-temperature heat exchange components.

Gasification-based power generation systems offer the highest efficiencies for advanced systems, with IGFC efficiencies projected by DOE to be about 60 percent. Potential advantages of coal gasification combined-cycle systems include the high efficiencies obtained with a combined-cycle configuration, superior environmental performance, and the capability to replace natural gas combined-cycle systems in existing power plants. Thus, a strong incentive has been 
established for the development of high-efficiency coal gasification technologies optimized for power generation. The committee notes that gasification is also an important first step in the production of clean gaseous and liquid fuels from coal, as discussed below. Given the high cost of developing advanced power generation systems, the committee does not consider large-scale demonstration of numerous technology options with significant DOE cost sharing to be justified.

The committee recommends that second- and third-generation gasification-based systems be given the highest priority for new plant applications. Work on all the advanced systems should focus on acquiring the cost, emissions control, and efficiency information needed to select the most promising systems for further development. The limitations of critical components, such as heat exchangers, turbines, and fuel cells, and the timing and probability of technological success should be taken into account. This process should begin before FY 1996 and should include a rigorous comparative study of the design options.

The proposed FY 1995 budget supporting advanced combined-cycle systems in the FE R\&D program is $\$ 173$ million, split between the natural gas program ( $\$ 113$ million for fuel cells and advanced turbines) and the coal program ( $\$ 60$ million for IGCC, PFBC, and indirectly fired cycle [ $[\mathrm{FC}]$ ). In contrast, the proposed FY 1995 budget is $\$ 8$ million for advanced pulverized coal. Within the coal program, DOE accords the highest funding level proposed for FY 1995 to the gasification combined-cycle systems ( $\$ 28$ million).

The Advanced Turbine Systems program, funded under the natural gas component of the FE R\&D program, is charged with considering alternative fuels to natural gas, including coalderived gas. In the opinion of the committee, advanced turbine materials alone will not be capable of resisting the corrosive effects of impurities in coal-derived gas, and a high level of gas cleanup will be needed. While cold gas cleanup can meet the necessary requirements for IGCC systems, hot gas cleanup has the potential for a simpler and lower cost approach and is an important part of the program to achieve DOE's efficiency goals for advanced technologies. Thus, hot gas cleanup is a high-priority area for both the CCT and the FE coal R\&D programs. To date, neither hot gas desulfurization systems nor the more critical hot gas particulate removal systems has achieved the performance or cost requirements for commercial systems.

The committee recommends that a critical assessment of hot gas cleanup systems for advanced IGCC and PFBC be undertaken immediately to determine the likely costs and the ability to meet, within the next three to five years, all requirements for future hightemperature $\left(>1260^{\circ} \mathrm{C}\left[2300^{\circ} \mathrm{F}\right]\right)$ turbine operation and environmental acceptability.

\section{Commercialization Efforts}

The increased complexity of advanced power generation systems implies not only that commercialization of new technology will be expensive but also that prudent stepwise scale-up from pilot plant through demonstration to commercial systems is necessary to minimize the technical risk at each stage. Thus, demonstration plants-such as those being constructed and operated under the CCT program-are an important step in establishing a commercially available 
technology. Given the high cost of advanced technology demonstrations, the committee recognizes the need for DOE cost sharing to promote U.S. technical leadership and competitiveness, particularly in environmental technologies. The majority of the ongoing CCT projects address advanced electric power generation systems and associated high-performance pollution control devices. While most of the demonstrations are not yet complete, the level of private sector support suggests that the programs have generally been thoughtfully chosen.

The committee recommends that DOE support of the current Clean Coal Technology program be continued and that the ongoing program be completed. While no further solicitations are planned under the existing CCT program, the FE coal R\&D program should continue to cofund demonstrations of selected Group 2 and Group 3 advanced clean coal technologies beyond those currently being demonstrated by the CCT program.

When advancing a new technology to commercial maturity, the first-of-a-kind (or pioneer) commercial plant is generally more costly to build than subsequent plants and provides only partial information about operating, maintenance, and cost issues. Between two and five applications of a new technology are generally required for it to be considered mature and commercially demonstrated. The committee concluded that federal cost sharing of the risk differential between pioneer coal-based power plants and commercially available technologies has the potential to accelerate the commercial acceptance of many of the new technologies such that they will be available to meet market needs in the mid-term period (2006-2020).

The committee recommends that an incentive program be developed and implemented that would offset the capital and operating cost risks associated with early commercial applications of technologies previously demonstrated at a commercial scale.

\section{CLEAN FUELS FROM COAL}

Coal gasification is a costly and energy-consuming first step for all advanced coal uses. Current industry and DOE development of gasification systems, notably under the CCT program, focuses on needs for IGCC power generation; significant improvements in efficiency over current commercial systems are possible. In light of the outstanding promise of IGCC systems, as well as the production needs for clean gaseous and liquid fuels, the committee considers gasification to be an important area for R\&D.

The requirements for gasification systems optimized specifically for power generation can differ from gasification systems suitable for production of marketable industrial gas, synthetic natural gas (SNG), and liquid transportation fuels. For example, air-blown systems with hot gas cleanup-if workable-might be appropriate for isolated power generation facilities, whereas for other uses and coproduct systems a higher level of cleanup is generally required, and dilution by nitrogen is undesirable. The committee considers gasification systems for both power generation and fuels production to be of importance for the DOE coal program, although there is currently little DOE activity on gasifiers aimed at the latter application. Opportunities for 
improvement are discussed in Chapters 6 and 9, where the committee identified an important role for DOE.

The committee recommends that an expanded DOE role be established to ensure the timely availability of the most efficient and economic gasification systems for future uses of coal in power generation and the production of clean gases and liquids.

Syngas can be converted by the Fischer-Tropsch process to produce liquid fuels and chemicals (indirect liquefaction), or it can be converted to hydrogen for subsequent reaction with coal to produce clean liquid fuels (direct liquefaction). The thermal efficiencies of direct and indirect liquefaction are estimated to be 60 percent and 50 to 55 percent, respectively.

For indirect liquefaction using Eastern bituminous coal and utility financing, ${ }^{2}$ recent estimates of equivalent crude price fall between $\$ 30$ and $\$ 35 / \mathrm{bbl}$. Use of lower-cost Western coals is projected to reduce this cost by approximately $\$ 4 / \mathrm{bbl}$. Studies of once-through FischerTropsch synthesis with coproduction of electricity in an advanced IGCC facility indicate an equivalent crude cost reduction of $\$ 5$ to $\$ 7 / \mathrm{bbl}$. For stand-alone direct liquefaction plants, equivalent petroleum prices also are estimated to be in the $\$ 30$ to $\$ 35 / \mathrm{bbl}$ range. Use of lowercost Western coal together with coproduction of electricity and hydrogen for direct liquefaction would further reduce costs.

The above estimated costs of coal liquids are substantially lower than the costs presented in an earlier National Research Council study (NRC, 1990). The differences result from a combination of technological advances, higher prices for the low-sulfur and high-hydrogen content of the transportation fuels produced, the economic bases for the estimates, and, in some cases, the higher efficiencies resulting from coproduction with electricity. While the FischerTropsch process is of great current interest to the petroleum industry for use in parts of the world where low-cost natural gas is available, $R \& D$ in direct liquefaction is, to an increasing extent, dependent on the DOE program to reach the target price of $\$ 25 / \mathrm{bbl}$ (1991 dollars; DOE, 1993b). However, a substantial reduction in funding (50 percent) for the DOE liquefaction program has been proposed for FY 1995. Given the historically unpredictable behavior of international oil markets and the current very limited industrial R\&D on coal liquids, the committee believes that an important role for the DOE coal program is to maintain and develop U.S. technical expertise in coal liquefaction, thereby establishing the potential to reduce U.S. petroleum imports.

The more attractive economics for coal-derived liquids suggested in recent studies are dependent on the substantial premium now paid for diesel and jet fuels with zero aromatic and sulfur content. This premium accounts, in part, for the current international interest in converting natural gas to these products; however, overproduction could reduce the premium and diminish the attractiveness of liquids from coal. While such uncertainties reduce the incentive for large pilot plant and demonstration programs, the committee believes that there is a clear incentive for continued cost reduction through systems studies and research, including the evaluation of innovative concepts for direct liquefaction. Since 10 to 15 years are necessary to

\footnotetext{
${ }^{2}$ Utility financing assumes 25 percent equity and 15 percent internal rate of return. See Chapter 2 and the Glossary for a more complete discussion of financing.
} 
complete a development and commercialization program, and since an equivalent crude price in the mid- $\$ 20 / \mathrm{bbl}$ does not seem unreasonable by 2010 , there appears to be an opportunity for an important contribution by DOE to coal liquefaction technology.

The committee recommends that DOE's program for coal liquefaction technologies be continued at least at the FY 1994 level, with the goals of decreasing the cost of coal liquids and increasing overall efficiency.

Another opportunity lies in the coproduction of coal liquids and electric power. The commercial deployment of IGCC power systems is anticipated in the mid-term period, and opportunities may arise to establish coproduct plants-or "coal refineries" - to meet demands for both power generation and fuels. This strategy would reduce the financial risk associated with constructing large stand-alone liquefaction plants, although some increase in the financial risk associated with the power plant may be anticipated.

The committee recommends that an assessment of strategies for coproduction of premium liquid fuels with gasification-based power be an important component in planning a program for the introduction of liquid fuels from coal.

\section{SYSTEMS ANALYSIS}

Advanced coal-based systems for the production of electricity, fuels, and other products are characterized by increasing technical complexity and an expanding number of process options. Given the constraints on funding for DOE's coal program, and the high cost of developing and demonstrating advanced systems, the committee noted a need for quantitative assessment of the relative merits of different systems and subsequent choice of options to be pursued. Systems analysis has the potential to assist in such assessments, notably in selection of the most promising designs, optimization of complex process configurations, assessment of performance and cost advantages, process risks and trade-offs, and targeting of R\&D to reduce critical uncertainties. Although DOE has a systems analysis activity spread among headquarters and its Morgantown Energy Technology Center (METC) and its Pittsburgh Energy Technology Center (PETC), the committee concluded that a major shortcoming of the current approach is a lack of systematic methods, assumptions, and design premises within and across the full suite of advanced energy conversion and environmental control processes.

The committee recommends an expanded and more prominent role for systems analysis in the development of RDD\&C strategies within DOE's coal program. This activity should establish a clearly stated and consistent set of criteria, assumptions, and design premises that can be applied to all technologies in a given category to facilitate rigorous comparisons. Advanced methods of analysis, design, and risk evaluation should be adopted, and extensive interaction with the user community-notably U.S. industry-and active dissemination of major study results and methods should be pursued. 
One application of the systems analysis activity identified by the committee is a thorough assessment and optimization of gasification systems, taking into account the likely future spectrum of gasification products. Similar assessments are also required for advanced power systems.

\section{EPACT}

In developing its conclusions and recommendations regarding future emphasis and priorities for DOE's coal program, the committee used a set of strategic planning criteria and scenarios for the near-, mid-, and long-term time periods, as discussed above and elaborated in Chapter 4. A major input to strategic planning is encompassed in the coal-related provisions of EPACT, which list technology areas and actions to be pursued by DOE.

In the final part of Chapter 10, the committee's conclusions and recommendations are interpreted in the context of EPACT. The committee's comments on DOE's response to individual coal-related sections of EPACT are summarized in Table 10-4. Priorities are given for DOE activities based on the committee's strategic planning approach, the development status of the technologies, and other industrial and federal programs. For example, if technologies are available commercially, the committee generally recommended low priority for DOE activities. Similarly, if there is extensive R\&D in the private sector, the committee recommended that DOE leverage these efforts. The committee concluded that the current DOE coal program is responsive in varying degrees to all the coal-related provisions of EPACT addressed in the study. However, the committee observed that the balance of activities in the current DOE coal program differs from that mandated by EPACT.

The committee concluded that the DOE Advanced Clean/Efficient Power Systems program responds to the EPACT sections relating to coal-based power generation and is consistent with projected market demands for new generating capacity in the mid- and long-term periods (2006-2040). In this context the committee endorses DOE's decision to terminate the magnetohydrodynamics proof-of-concept program. Magnetohydrodynamics does not appear to offer significant advantages over other high-efficiency systems, and the next step in development would involve a costly demonstration program with high technical risk. While the committee considered the current CCT program to be an excellent start in the commercialization of advanced power generation technologies, it concluded that prevailing conditions in the power generation industry will necessitate further federal cost-sharing programs to accelerate commercial acceptance of many of these new technologies. The committee's major recommendations pertaining to EPACT Section 1301 (c), subparagraphs $c(3), c(4)$, and $c(5)$ are given above (see "Commercialization Efforts").

In contrast to power generation, the committee concluded that DOE activities in coal liquefaction fall short of EPACT requirements. Given the likely growth in demand for coal-based liquid fuels in the mid- to long-term periods and the decline in industrial liquefaction R\&D, the committee considered that the priority accorded DOE liquefaction activities within EPACT is well founded and should be reflected in a revised DOE coal program. The committee recognizes that the decline in DOE support for liquefaction in recent years may be the result of funding constraints, a decline in international oil prices, and a high priority on shorter-term requirements 
to develop advanced power generation technologies. Nevertheless, the committee concluded that DOE should redress the balance of its fuel and power generation activities within the coal program to reflect the priorities of EPACT, commensurate with a planning horizon that assumes coal will continue to be a major domestic energy source well beyond 2010.

\section{REFERENCES}

DOE. 1993a. Foreign Markets for U.S. Clean Coal Technologies, Working Draft. December 21. Report to the U.S. Congress by the U.S. Department of Energy, Washington, D.C.

DOE. 1993b. Clean Coal Technologies: Research, Development, and Demonstration Program Plan. U.S. Department of Energy, DOE/FE-0284. Washington, D.C.: DOE.

EIA. 1994. Annual Energy Outlook 1994. Energy Information Administration, U.S. Department of Energy, DOE/EIA-0383(94). Washington, D.C.: DOE.

Merrow, E.W., K.E. Phillips, and C.W. Meyers. 1981. Understanding Cost Growth and Performance Shortfalls in Pioneer Process Plants. Prepared by the Rand Corporation for U.S. Department of Energy, R-2569-DOE. Santa Monica, California: Rand Corporation.

NRC. 1990. Fuels to Drive Our Future. Energy Engineering Board, National Research Council. Washington, D.C.: National Academy Press. 
PART I

STRATEGIC PLANNING FOR COAL 


\section{Introduction and Scope of the Study}

The fossil fuels coal, petroleum, and natural gas have been central in supplying reliable, low-cost energy in the United States for more than a century. Today they account for almost 90 percent of the nation's primary energy consumption. The domestic coal resource base is extensive, representing over 94 percent of proven U.S. fossil energy reserves (DOE, 1993). While the United States imports significant amounts of oil and gas, coal is a net export commodity for the U.S. economy.

Coal prices declined in real terms through most of the 1980s, due primarily to higher mining productivity, overcapacity, and competition from natural gas. The abundance and low cost of coal make it an attractive fuel, but the environmental controls required for coal combustion, together with the inconvenience of handling a solid fuel, have made natural gas and oil the fuels of choice in developed nations for many domestic, commercial, and industrial applications. Of the total 1992 U.S. domestic energy production, 32 percent (21.6 quadrillion Btu) was coal, 27 percent natural gas, and 23 percent crude oil, with the remaining 18 percent from nuclear power and renewables (EIA, 1993a).

Electricity generation is the single largest use of coal in the United States. Electric utilities consumed 87.4 percent of the total 1992 coal consumption of 892 million tons, while industrial users consumed 8.3 percent and coke plants 3.6 percent (EIA, 1993b). Over the past 20 years the electric utility industry's coal consumption has doubled. In 1992 coal-fired steam electricity generating plants accounted for 56 percent of the electricity produced in the United States.

Coal's continued viability as a domestic energy source will be strongly linked to its environmental acceptability relative to that of competing fuels such as natural gas. Research, development, demonstration, and commercialization (RDD\&C) programs will therefore be critical in ensuring that coal technologies meet or exceed requirements for acceptable use and that they are available for timely deployment. The present study assesses the directions of coal RDD\&C strategies and priorities for the United States, with emphasis on programs funded by the U.S. Department of Energy (DOE).

The scope and objectives of this National Research Council study and the committee's approach to its task are further detailed below. Prior to reviewing DOE's coal programs and planning in Chapter 2, some essential background is provided in this chapter on relevant coalrelated provisions of the Energy Policy Act of 1992 (EPACT) and on coal-related research and development $(\mathrm{R} \& \mathrm{D})$ outside $\mathrm{DOE}$, both in the private sector and overseas. 


\section{THE ENERGY POLICY ACT OF 1992}

The major impetus for this study, EPACT, represents the culmination of several years of energy policy deliberations, prompted largely by the Bush administration's 1991 National Energy Strategy proposals (DOE, 1991). EPACT provides congressional guidance on a wide range of energy-related issues. Its provisions are intended to support a more competitive economy, a cleaner environment, and increased energy security.

EPACT enumerates many coal-related RDD\&C activities, specifically as shown in Box 1-1. (Key coal-related provisions of the act are discussed further in Chapter 10 and reproduced in full in Appendix B.) The act gives the Secretary of Energy certain responsibilities for DOE's coal program and further requires the Secretary to submit reports to the Congress, including a plan to meet the objectives defined in the act's Title XIII-Coal, Section 1301. These high-level objectives focus on ensuring a reliable electricity supply, increasing the environmental acceptability of coal technologies, and achieving the cost-competitive conversion of coal to transportation fuels. Relevant technologies are to be available for commercial use by 2010 . In addition to Subtitle A, subtitles B and C of Title XIII and Subtitle A of Title XX identify other coal-related activities to be implemented by DOE.

The principal technical areas EPACT identifies in sections relating to coal are electric power generation and conversion of coal to liquid and gaseous fuels. Nonfuel uses of coal-for coke, chemical feedstocks, and other products-also are addressed. EPACT emphasizes improving the environmental acceptability of the entire coal fuel cycle, from coalbed methane recovery, through power generation and conversion to fuels, to the utilization of coal wastes. A distinction is made between RDD\&C activities described in Subtitle A of Title XIII and the Clean Coal Technology (CCT) program described in subtitles B and C. As discussed in Chapter 2 , the latter program specifically addresses the need for cost-effective, high-efficiency, lowemission coal technologies ready for commercial application by 2010 .

\section{STUDY SCOPE AND OBJECTIVES}

In May 1993 the DOE's Acting Assistant Secretary for Fossil Energy requested that the National Research Council assess DOE's coal program. In keeping with this request, the National Research Council formed the Committee on Strategic Assessment of the U.S. Department of Energy's Coal Program (see Appendix G for biographical sketches of committee members), to address the broad priorities that DOE's Office of Fossil Energy ought to consider in updating its strategic plan and in responding to EPACT. Recent or current DOE programs have addressed, or are addressing, many of the areas identified in EPACT.

The National Research Council committee was specifically charged as follows:

- Review the DOE coal program, including the current version of the coal strategic plan and additional details contained in the administration's budget requests for fiscal year (FY) 1994 and FY 1995, as appropriate.

- Review the relevant sections of EPACT (identified above in Box 1-1) and the DOE coal program vis-à-vis both EPACT provisions and coal-related R\&D outside DOE. 
- Recommend objectives, including performance and schedule, that ought to be emphasized for those areas in EPACT that are not in the current DOE coal program.

- Make recommendations pertaining to EPACT Section 1301(c), especially subparagraphs $c(3)$ through $c(5)$, which relate to the modification and extension of existing demonstration and commercialization programs to ensure the timely availability of advanced coal-based technologies.

- Identify priorities for DOE's future coal program, based on the foregoing reviews and recommendations and on the assumption that the future budgets appropriated for the DOE coal program will remain at the FY 1994 level in real terms.

(See Appendix A for a detailed description of the project and the charge to the committee.)

\section{THE COMMITTEE'S APPROACH}

To address its charge, the committee conducted four major tasks: (1) acquisition and review of information on DOE's current coal programs and planning; (2) development of a strategic planning framework, including criteria for program objectives, timing, and priorities; (3) assessment of current and alternative coal RDD\&C activities in the context of EPACT and the committee's strategic planning framework; and (4) development of conclusions and recommendations based on all the foregoing committee activities.

DOE's "Coal Strategic Plan" was still in preparation and not available during the conduct of the study. The committee therefore used a number of other documents that DOE provided to obtain an overview of current and planned coal-related RDD\&C activities. Documentation provided by DOE is referenced as appropriate throughout this report. This information was supplemented by DOE staff presentations to the committee (see Appendix F).

In developing a framework for strategic assessment of the DOE program, the committee sought to reflect the key factors likely to affect future coal use in the United States and elsewhere. Scenarios were developed for three time periods: near-term (1995-2005), mid-term (2006-2020), and long-term (2021-2040). The committee defined these time periods based on anticipated major trends in coal use. For the near-term period-over the next 10 years-scenarios for coal use will likely remain similar to those of today. Power generation will continue to be the principal U.S. use of coal, although the need for new baseload power generation facilities will be low. The mid-term period (2006-2020) will likely be one of transition. Power generation will remain the largest coal use, with substantial demand for new generating capacity. Interest in the production of synthetic fuels from coal will also likely increase significantly in response to rising international oil prices. In the long term (2021-2040) the balance of coal uses may well shift, with liquids and other clean fuels from coal becoming increasingly important compared to power generation. The emphasis on power generation will continue to be significant, but the need to minimize carbon dioxide $\left(\mathrm{CO}_{2}\right)$ and other emissions will impose severe demands on efficiency and emission control systems, resulting in increased interest in other energy sources.

To develop scenarios for the three periods and related RDD\&C planning criteria, the committee devoted significant effort to identifying those factors that would affect the use of coal (see Chapter 3). The committee explored alternative views of future energy needs, environmental 
control requirements, institutional factors, international developments, and resource availability. The information and perspectives developed were then used to assess current DOE programs and to draw conclusions and recommendations consistent with the committee's strategic planning framework and its overall charge.

\section{COAL RESEARCH AND DEVELOPMENT}

Over the years, R\&D has been conducted in the United States on all stages of the coal fuel cycle, from mining to end use, in both private and public sectors. Coal R\&D has also been undertaken overseas and has been pursued cooperatively between the United States and other countries. The pace of domestic R\&D has been uneven, depending on economic circumstances, perceived U.S. vulnerability to energy interruptions, and the reality of such energy problems as the 1973 oil embargo by the Organization of Petroleum Exporting Countries (OPEC). The following brief discussion of private sector and international activities provides some general background for the committee's assessment. Specific private and international programs, such as the development of Fischer-Tropsch (F-T) processes and of gasification technology, are addressed in later technical discussions of the DOE program.

\section{Private Sector Activities}

R\&D by the private sector has been affected by the ebb and flow of government support for coal-related R\&D, although much $R \& D$ has been carried out independent of government support, driven mainly by perceived economic opportunities. Prior to the 1973 OPEC oil embargo, the private sector was involved in technical developments relating to coal mining, electric power generation, and, to a lesser degree, coal liquefaction. The subsequent energy uncertainties of the 1970s resulted in rapid price rises for petroleum and natural gas. With some forecasts projecting high petroleum prices for the longer term, the private sector envisioned opportunities to produce liquid fuels or synthetic natural gas from resources other than gas or petroleum. Programs were undertaken on technologies to exploit coal, oil shale, tar sands, biomass, and other nonconventional domestic resources, but these programs have now largely been abandoned.

Coal gasification technologies have been pursued extensively by private industry. Gasification is a critical step in converting coal to electricity, liquid fuels, or synthetic natural gas, and/or any number of chemicals, including methanol, petrochemicals, and ammonia. Commercial coal gasification plants in the United States include the Great Plains Gasification Plant, the Dow gasification-cogeneration plant, and the Tennessee Eastern syngas-to-chemicals plant.

Coal technologies to produce electric power have been pursued extensively by both the private sector and DOE. The Electric Power Research Institute (EPRI), which is funded by the utility industry, is developing advanced electricity generation technologies powered by coal, with a current annual coal R\&D budget of approximately $\$ 150$ million, excluding cosponsors' funds. 
In addition, the private sector will contribute approximately two-thirds of the total $\$ 6.9$ billion budgeted for the DOE's CCT program.

\section{International Activities}

In Organization for Economic Cooperation and Development (OECD) countries, the most important consideration for future coal use is environmental. $R \& D$ programs within the $O E C D$ emphasize the development of cost-effective clean coal technologies to limit sulfur dioxide $\left(\mathrm{SO}_{2}\right)$, oxides of nitrogen $\left(\mathrm{NO}_{x}\right)$, and $\mathrm{CO}_{2}$ emissions from power plants (IEA, 1993). A number of OECD countries, including the United States, are also pursuing R\&D individually to compete for the large anticipated markets for clean coal technologies in China, India, and other nonOECD nations. Outside the United States, the major effort to develop clean coal technologies is within the European Union (EU). Japan's New Energy and Industrial Technology Development Organization is funding a clean coal technology program, and there are limited clean coal technology developments in Australia, but these activities are not of the magnitude of the U.S. effort to develop and commercialize clean coal technologies.

EU coal programs are aimed at ensuring the availability and use of technologies for clean, cost-effective exploitation of coal, which provides nearly 40 percent of EU power generation requirements. The EU Energy Demonstration program (1978-1989) provided financial support to pilot and demonstration projects in liquefaction, gasification, and combustion of solid fuels. EU grants totaling 302 million ECUs made up about 40 percent of the program costs (ECUs = European currency units; at present $1 \mathrm{ECU}=\mathrm{US} \$ 1.15$ ). The EU THERMIE program (1990-1994) was aimed at promoting greater use of European energy technologies and at developing new clean processes, notably for the combustion and conversion of solid fuels. EU funding for this program was about 150 million ECUs annually, with additional funding coming from industry participants and governments of EU member nations. Clean coal technologies supported by THERMIE include transport fuels from coal, $\mathrm{NO}_{\mathrm{x}}$ emission controls, atmospheric fluidized-bed combustion (AFBC), pressurized fluidized-bed combustion, gasification, and an integrated gasification combined cycle (IGCC) plant (Commission of the European Communities, 1992).

\section{ORGANIZATION OF THE REPORT}

The remaining chapters in Part I of this report elaborate on issues and findings central to the committee's formulation of a strategic planning framework. Chapter 2 provides an overview of current DOE coal-related programs and planning, highlighting the current program structure and recent budget trends. Chapter 3 discusses principal issues for future U.S. coal use, including potential markets, the requirements for coal use, the domestic energy resource base, and competing energy sources for various applications. Special attention is given to environmental requirements and the institutional factors that will shape the future of coal technologies. The findings presented in chapters 2 and 3 were used by the committee to develop 
a framework for DOE strategic planning, a framework summarized in Chapter 4. This framework provides the basis for a more detailed assessment of DOE programs and planning.

Part II of the report (chapters 5-9) provides more detailed evaluations of current DOE programs with respect to the strategic planning criteria. Chapters 5 through 7 follow the fuel cycle, with Chapter 5 addressing coal preparation, coal-liquid mixtures, and coalbed methane recovery: Chapter 6 addresses coal conversion to clean fuels and specialty products, and Chapter 7 covers electric power generation. Chapter 8, on technology demonstration and commercialization, and Chapter 9 , on advanced research programs, describe a variety of crosscutting activities within DOE's coal program. In all. cases the discussions focus on the main technical issues, including both risks and opportunities, that must be considered in developing a coal program.

In the final section of the report, Part III, the information in parts I and II is synthesized to develop conclusions and recommendations on the strategic priorities for DOE's RDD\&C on coal-related technologies and to address other provisions of the committee's charge related to EPACT (Chapter 10). Appendixes provide additional background in support of the committee's work. A glossary provides explanations of the acronyms used and of major technical and economic conventions the committee adopted.

\section{REFERENCIES}

Commission of the European Communities. 1992. Coal Can Be Green-A Review of Coal Technologies Supported by the European Community. Brussels: Directorate-General for Energy (DG XVII).

DOE. 1991. National Energy Strategy, First Edition 1991/1992. Washington, D.C.: U.S. Government Printing Office.

DOE. 1993. Clean Coal Technologies: Research, Development, and Demonstration Program Plan. U.S. Department of Energy, DOE/FE-0284. Washington, D.C.: DOE.

EIA. 1993a. Monthly Energy Review, October 1993. U.S. Department of Energy, Energy Information Administration. DOE/EIA-0035 (93-10). Washington, D.C.: DOE.

EIA. 1993b. Coal Production 1993. U.S. Department of Energy, Energy Information Administration. DOE/EIA-0118(92). Washington, D.C.: DOE.

IEA. 1993. Annual Report 1992-1993: International Energy Agency Coal Research. Paris: Organization for Economic Cooperation and Development. 
Box 1-1

Sections of the 1992 Energy Policy Act Considered by the Committee

TITLE XIII-COAL

Subtitle A: Research, Development, Demonstration, and Commercial Application Section 1301: Coal Research, Development, Demonstration, and Commercial Application Programs

Section 1302: Coal-Fired Diesel Engines

Section 1303: Clean Coal, Waste-to-Energy

Section 1304: Nonfuel Use of Coal

Section 1305: Coal Refinery Program

Section 1306: Coalbed Methane Recovery

Section 1307: Metallurgical Coal Development

Section 1308: Utilization of Coal Waste

Section 1309: Underground Coal Gasification

Section 1310: Low-Rank Coal Research and Development

Section 1311: Magnetohydrodynamics

Section 1312: Oil Substitution Through Coal Liquefaction

Subtitle B: Clean Coal Technology Program

Section 1321: Additional Clean Coal Technology Solicitations

Subtitle C: Other Coal Provisions

Section 1332: Innovative Clean Coal Technology Transfer Program

Section 1336: Coal Fuel Mixtures

Section 1337: National Clearinghouse

TITLE XX - GENERAL PROVISIONS; REDUCTION OF OIL VULNERABILITY

Subtitle A: Oil and Gas Supply Enhancement

Section 2013: Natural Gas Supply 


\section{Overview of U.S. Department of Energy Programs and Planning}

This chapter reviews trends in DOE's coal program since the late 1970s and outlines the current program structure and recent budgets. DOE's current strategic planning also is summarized.

\section{MAJOR TRENDS IN THE DOE COAL PROGRAM}

Trends in federal funding for coal-related R\&D since DOE's inception are illustrated in Figure 2-1. The 1973 oil embargo and subsequent energy supply uncertainties of the 1970s led to a greater federal role in energy technology development, with increased effort directed at more secure energy supplies, as through greater reliance on plentiful domestic coal. Efforts were focused especially on developing more efficient, cost-effective, and environmentally acceptable coal technologies. The 1980 Energy Security Act established the Synthetic Fuels Corporation to develop the domestic nonconventional energy resources, such as liquid fuels from coal and oil shale. This increased federal interest was reflected in the rapid growth of DOE's Office of Fossil Energy (FE) coal R\&D budget in the late 1970s, as Figure 2-1 shows.

The intense interest in and funding of federal energy R\&D during the 1970s was replaced by the Reagan administration with an emphasis on decontrolling energy markets, relying more on the free market and the private sector. There were significant reductions in federally sponsored fossil energy R\&D, cancellations of synthetic fuels demonstration plants, and the eventual phase-out of the Synthetic Fuels Corporation. The marked drop in coal R\&D funding from FY 1981 to FY 1982 was largely attributable to very significant reductions in funding for coal liquefaction and surface coal gasification activities (see Appendix C). A sharp decline in the world petroleum price in 1986 substantially decreased the economic attractiveness of coalderived petroleum substitutes and the perceived need for $R \& D$ in this direction.

However, sustained interest in coal-based power generation technologies led to congressional funding of DOE's CCT program, starting in FY 1986. This program has constituted a major effort outside the traditional coal R\&D projects undertaken by DOE and its predecessor organizations, and CCT funding is therefore not included in Figure 2-1. The CCT program has emphasized the need for demonstration and commercial deployment of environmentally responsive, economically competitive technologies and is based on cost sharing 
between the private sector and DOE, with the former contributing at least 50 percent of total demonstration cost.

During the Bush administration, the National Energy Strategy report was published, providing an overall administration strategy for energy policy (DOE, 1991). A fundamental tenet of this strategy was to continue reliance on market forces wherever possible by removing any barriers to efficient market operation. Emphasis was placed on improving energy efficiency and increasing production of domestic oil and natural gas. Coal was recognized as an important domestic source of energy, with emphasis on the development of economically viable technologies achieving specified levels of environmental performance relating to acid rain precursors and greenhouse gas emissions. Thus, in the area of electric power generation, advanced systems characterized by high efficiency, very low pollutant emissions, and competitive economics became the focus of DOE's coal program. Another recognized need was for $R \& D$ to reduce the costs, investment risks, and environmental impacts of producing liquid fuels from coal.

An important initiative of the Clinton administration has been the Climate Change Action Plan. This plan lays out the goals of returning U.S. greenhouse gas emissions to their 1990 levels by the year 2000 and positioning the United States to compete better in the global market (Clinton and Gore, 1993). A main thrust of this initiative is to reduce energy demand throughout the U.S. economy by actions that align market forces with the goal of reducing greenhouse gas emissions. Thus, the Clinton administration has promoted increased use of natural gas (which emits less $\mathrm{CO}_{2}$ per unit of energy than coal or oil), improved energy efficiency, and renewable energy technologies that release no net $\mathrm{CO}_{2}$ to the environment. As discussed below, decreased coal R\&D funding has accompanied these new emphases.

\section{THE DOE COAL PROGRAM STRUCTURE AND BUDGET}

DOE's coal-related activities currently fall under two main budget categories: FE R\&D and the CCT program. The first category also includes $R \& D$ programs in petroleum and natural gas, which are not considered in the present report, except when directly relevant to the coal program (e.g., cross-cutting R\&D in advanced turbines and fuel cells). The CCT program was initiated in 1986 and is scheduled to run through 2004, with the specific goal of demonstrating the commercial potential of advanced power generation technologies. The CCT program is thus more transient than FE R\&D, which has been in existence since the inception of DOE and forms the continuing basis of DOE's coal program.

\section{Fossil Energy Research and Development}

Annual funding for FE R\&D for FY 1992 through the FY 1995 budget request has remained relatively constant, at something over $\$ 400$ million. However, the oil and natural gas 
program budgets have increased at the expense of the coal program (Figure 2-2). ${ }^{1}$ Fossil fuel prices have declined during the past several years, especially for gas and oil. The low current and projected price of natural gas has resulted in an emphasis on technologies for gas utilization, with the potential to use coal-derived gas. Recent years have seen the completion of R\&D on power plant emissions controls to prevent acid deposition, and the initiation of new activities to achieve lower emissions of conventional air pollutants and higher power cycle efficiencies. These activities reflect a change in emphasis within the coal portion of the FE R\&D program, with a decline in proof-of-concept activities and an increase in funding for demonstration programs. The current program addresses both $\mathrm{R} \& \mathrm{D}$ and technology demonstration.

Table 2-1 shows trends in expenditures for the three main budget categories of the FE R\&D coal program: Advanced Clean Fuels, Advanced Clean/Efficient Power Systems, and Advanced Research and Technology Development (AR\&TD). A major change in the FY 1994 budget was the shifting of the fuel cell program from the coal component of the FE R\&D budget to the gas component. The total FE R\&D coal program budget has declined by about 25 percent (almost 30 percent in real terms) since FY 1992, not including the transfer of the fuel cell activity. DOE's FY 1995 request would bring the FE coal R\&D program budget (in constant dollars) to just over half what it was three years ago. However, the budget request is not necessarily a good indication of the final budget, since Congress historically has added funds that DOE did not request.

Both the Advanced Clean Fuels and Advanced Clean/Efficient Power Systems ${ }^{2}$ components of the coal program experienced funding reductions of about 30 percent (in current dollars) between FY 1992 and FY 1994. A significant part of the decrease in the second program area reflects completion of the magnetohydrodynamics program. High-efficiency IGCC is the only area in the Advanced Clean/Efficient Power Systems program that has seen funding increases each year from FY 1992 through FY 1994.

\section{CCT Program}

In the CCT program the most promising of the advanced coal-based technologies are being moved into the marketplace through demonstration. The demonstrations are at a scale large enough to generate the data needed to judge the commercial potential of the systems developed. Congress originally funded the CCT program with almost $\$ 400$ million, to be spread over FY 1986 through FY 1988. In March 1987, in response to the Joint Canadian and U.S. Special Envoy recommendations concerning acid rain, President Reagan expanded the CCT program's funding by $\$ 2.35$ billion. Congress established that this funding would be offered in five solicitations for cost-shared projects (CCT-Round I through CCT-Round V), in which industry would provide at least 50 percent of the cost of design, construction, and operation of the

\footnotetext{
'The fuel cell activity was transferred from the coal program to the natural gas program in FY 1994. However, for comparison purposes, fuel cell funding has been included in the natural gas budget rather than the coal budget illustrated in Figure 2-2.

${ }^{2}$ Excluding the fuel cell activity.
} 
demonstration project. A unique feature of the CCT program is that each project must commit to repaying the government's share of the project's funding from the proceeds of successful commercialization of the technology.

Table 2-2 shows currently authorized CCT funding, by solicitation round and fiscal year. The CCT program has been authorized and appropriated $\$ 2.75$ billion altogether, representing 45 active demonstration projects and a total public and private investment of $\$ 6.9$ billion. The FY 1995 budget request seeks to have previously authorized funding for the CCT program extended to cover solicitation rounds IV and V.

Section 1332 of EPACT calls for solicitations for CCT projects in developing countries or countries with economies in transition from a nonmarket to a market economy. The FY 1995 budget request seeks funding for international "showcase" demonstration projects in Eastern Europe and China. However, it remains unclear whether this will receive congressional approval.

\section{DOE'S STRATEGIC PLANNING}

\section{The Department of Energy Strategic Plan}

DOE's overall strategic plan (DOE, 1994b) defines the department's mission as follows:

The Department of Energy, in partnership with our customers, is entrusted to contribute to the welfare of the Nation by providing the technical information and the scientific and educational foundation for the technology, policy, and institutiónal leadership necessary to achieve efficiency in energy use, diversity in energy sources, a more productive and competitive economy, improved environmental quality, and a secure national defense.

The DOE plan provides a vision, goals, strategies, and success indicators for each of the department's five business areas. Under "Industrial Competitiveness, " DOE's laboratory system, R\&D capabilities, and core competencies in such areas as energy and environmental technologies are considered valuable resources the private sector can tap through collaborative programs. DOE work under "Energy Resources" is based on the assumption that fossil fuels will remain critical components of energy supply in every nation for the foreseeable future. In the United States, coal, natural gas, and oil will continue to provide most of the energy for electricity generation and the building, industrial, and transportation sectors. A major focus in this area is using fossil fuels more efficiently and cleanly. The business area "Science and Technology" faces the challenge resulting from the continuing industry shift away from basic research. Given constraints in federal spending, DOE must balance its long-term fundamental research against R\&D that will help industry compete effectively in the near term. Specific goals include providing the science and technology core competencies that will enable DOE's other businesses to succeed in their missions and adding value to the U.S. economy through the application of new and improved technologies. "National Security" is concerned primarily with transformation 
of the nuclear weapons complex, activities that are not within the scope of this report. Similarly, "Environmental Quality" addresses mainly nuclear issues, namely, the decontamination and decommissioning of weapons complex facilities and nuclear power plants.

The current DOE strategic plan generally expands on EPACT goals. EPACT will continue to provide guidance to the department in achieving its energy objectives, although, as DOE's plan notes, fulfilling EPACT's detailed requirements "will be difficult in this era of fiscal constraint."

\section{Clean Coal Technologies Research, Development, and Demonstration Program Plan}

DOE's Office of Fossil Energy is currently developing a "Coal Strategic Plan." As noted in Chapter 1, this document was not available during the conduct of this study. In the meantime, an important source of information on DOE's strategic planning for coal is its Clean Coal Technologies Research, Development, and Demonstration (RD\&D) Program Plan (DOE, 1993b). This planning document should be distinguished from the similarly named but programmatically distinct Clean Coal Technology program, that is, the program usually referred to as the CCT program. Activities described in the Clean Coal Technologies RD\&D Program Plan include, but are not limited to, the CCT program. For example, development of PFBC systems will involve subsystem and component testing, environmental and economic performance studies, and pilot plant tests, all funded under the FE R\&D program; first- and secondgeneration PFBC demonstrations will be conducted under the CCT program.

The RD\&D Program Plan focuses on near-term planning; it does not address requirements for coal utilization beyond 2010. (Thus, the planning horizon corresponds to the near-term period and first five years of the mid-term period defined by the committee.) This plan proposes activities that span the full cycle of technology development, from basic research through demonstration and commercialization. Private industry has an important role to play in all stages, with the degree of industry cost sharing expected to increase as a technology moves toward commercialization. In the CCT program the most promising advanced coal technologies are being moved into the market through demonstration at a scale that permits their commercial potential to be assessed; as noted earlier, industry partners must contribute at least 50 percent of the demonstration costs.

Activities described in the RD\&D Program Plan are aimed at enabling the use of plentiful U.S. domestic coal resources while meeting environmental requirements. Specifically, the following two program goals are defined:

- enabling the use of coal as a secure, low-cost domestic energy source to support economic competitiveness and employment growth and

- contributing to the environmental acceptability of coal utilization.

Three main program areas are defined: advanced power systems, advanced fuel systems, and cross-cutting technology programs. In the broadest terms these three program areas correspond to the three main budget categories of the FE coal R\&D program. However, the advanced power 
systems and advanced fuel systems areas in the RD\&D Program Plan also include CCT activities, and the detailed organization and funding of advanced research and cross-cutting technology programs is complex (see Chapter 9).

The advanced power systems program described in the RD\&D Program Plan supports the development of several coal combustion and coal gasification options, which are expected to become commercial at different times. The aim is to enable future coal-fired plants to produce lower-cost electricity with reduced environmental impacts, higher efficiency, and higher reliability levels and to accelerate commercialization of such technologies. This program's strategic objectives are shown in Table 2-3. More specific objectives for individual technologies are presented in the RD\&D Program Plan (DOE, 1993b).

The advanced fuel systems program described in the RD\&D Program Plan supports technologies to produce clean gaseous and liquid fuels and chemicals from coal, emphasizing liquid transportation fuels. There is no work on production of synthetic natural gas (SNG), except for some activities under coal gasification. DOE's strategic objective for the advanced fuel systems program is to demonstrate by 2010 "advanced concepts for production of coal-based transportation fuels, chemicals and other products" that can compete with petroleum products, when petroleum prices are $\$ 25 / \mathrm{bbl}$ or greater in 1991 dollars (DOE, 1993b), equivalent to $\$ 26 /$ bbl in 1992 dollars.

Different bases may be used for estimating production costs for liquid transportation fuels from coal. The electric utility industry with its relatively predictable selling prices for electricity and stable production costs can attract capital at a lower prime rate than, for example, the oil industry where future product and feedstock prices are much less certain. Major investments are frequently split between a component with relatively assured, but lower, return and a higher return component that will incur a larger risk. In the utility industry a substantially larger component of low-risk borrowed money is more common than in the petroleum industry, where 100 percent equity financing has been more commonly practiced. Hence, the term "utility financing" is frequently used to describe highly leveraged investments, whereas "petroleum financing" describes the smaller component of borrowed money generally employed in that industry. Utility financing has been used throughout the present report for consistency with DOE's approach (see Glossary for further details), although the committee notes that there is no general consensus on the most appropriate financing basis for estimating equivalent crude costs.

A number of technologies are relevant to both advanced power and advanced fuel systems. Four corresponding "cross-cutting" technology programs are described in the RD\&D Program Plan: coal preparation, alternative fuels utilization, flue gas cleanup, and waste management (DOE, 1993b). Progress in these areas can improve the efficiency, environmental performance, or life-cycle costs of many of the advanced power and fuel systems under development. Specific objectives are defined for each of the cross-cutting technology programs.

DOE's planning objectives for advanced power and fuels systems are evaluated later by the committee in the context of its own strategic planning framework (see Chapter 10). The study's conclusions and recommendations on DOE program goals and priorities stem from that evaluation. 


\section{SUMMARY}

Federal funding for coal R\&D has fluctuated substantially over the past two decades, particularly in response to the energy supply uncertainties of the 1970s. The DOE coal R\&D budget increased rapidly in the late 1970s, reaching a peak of over $\$ 1$ billion per year in FY 1981 (current dollars), but declined sharply in the early 1980s, especially funding for coal liquefaction R\&D. The FY $1994 \mathrm{FE}$ coal R\&D budget was less than $\$ 200$ million per year (current dollars), representing a decrease of approximately 50 percent in real terms over the past 10 years. Over the past three years, the oil and natural gas components of the FE R\&D program have grown at the expense of the coal component. The increase in natural gas funding is largely in response to the availability and environmental acceptability of low-cost natural gas, although the possibility of using coal-derived gas is recognized.

Since 1986, the CCT program, which is budgeted separately from the coal R\&D program, has been appropriated $\$ 2.75$ billion in federal funding for the demonstration of advanced coal technologies, with emphasis on clean, efficient power generation systems. The CCT program represents a marked departure from traditional DOE FE R\&D programs in that industry partners must contribute at least 50 percent of the demonstration cost. In addition, there is a strong emphasis on technology commercialization.

DOE's strategic planning for coal focuses on the need to exploit coal as a secure, lowcost domestic energy resource and to increase the environmental acceptability of coal use. DOE has defined corresponding quantitative goals for the advanced power and fuel systems programs. Partnership with industry is envisaged as a key component in the future development of coalbased technologies.

\section{REFERENCES}

Clinton, W.J., and A. Gore, Jr. 1993. The Climate Change Action Plan. Washington, D.C.: The White House.

DOE. 1991. National Energy Strategy. First Edition 1991/1992. U.S. Department of Energy. Washington, D.C.: DOE.

DOE. 1993a. FY 1994 Congressional Budget Request. U.S. Department of Energy, DOE/CE0012, Volume 4. Washington, D.C.: DOE.

DOE. 1993b. Clean Coal Technologies: Research, Development, and Demonstration Program Plan. U.S. Department of Energy, DOE/FE-0284. Washington, D.C.: DOE.

DOE. 1994a. FY 1995 Congressional Budget Request. U.S. Department of Energy, DOE/CR0023, Volume 4. Washington, D.C.: DOE.

DOE. 1994b. Strategic Plan: Fueling a Competitive Economy. U.S. Department of Energy, DOE/S0108. Washington, D.C.: DOE. 
DOE. 1994c. Clean Coal Technology Demonstration Program: Program Update 1993. U.S. Department of Energy, DOE/FE-0299P. Washington, D.C.: DOE.

Feibus, H. 1993. Overview of U.S. Department of Energy Coal Program. Presentation to the Committee on Strategic Assessment of DOE's Coal Program at the National Academy of Sciences, Washington, D.C., November 22. 


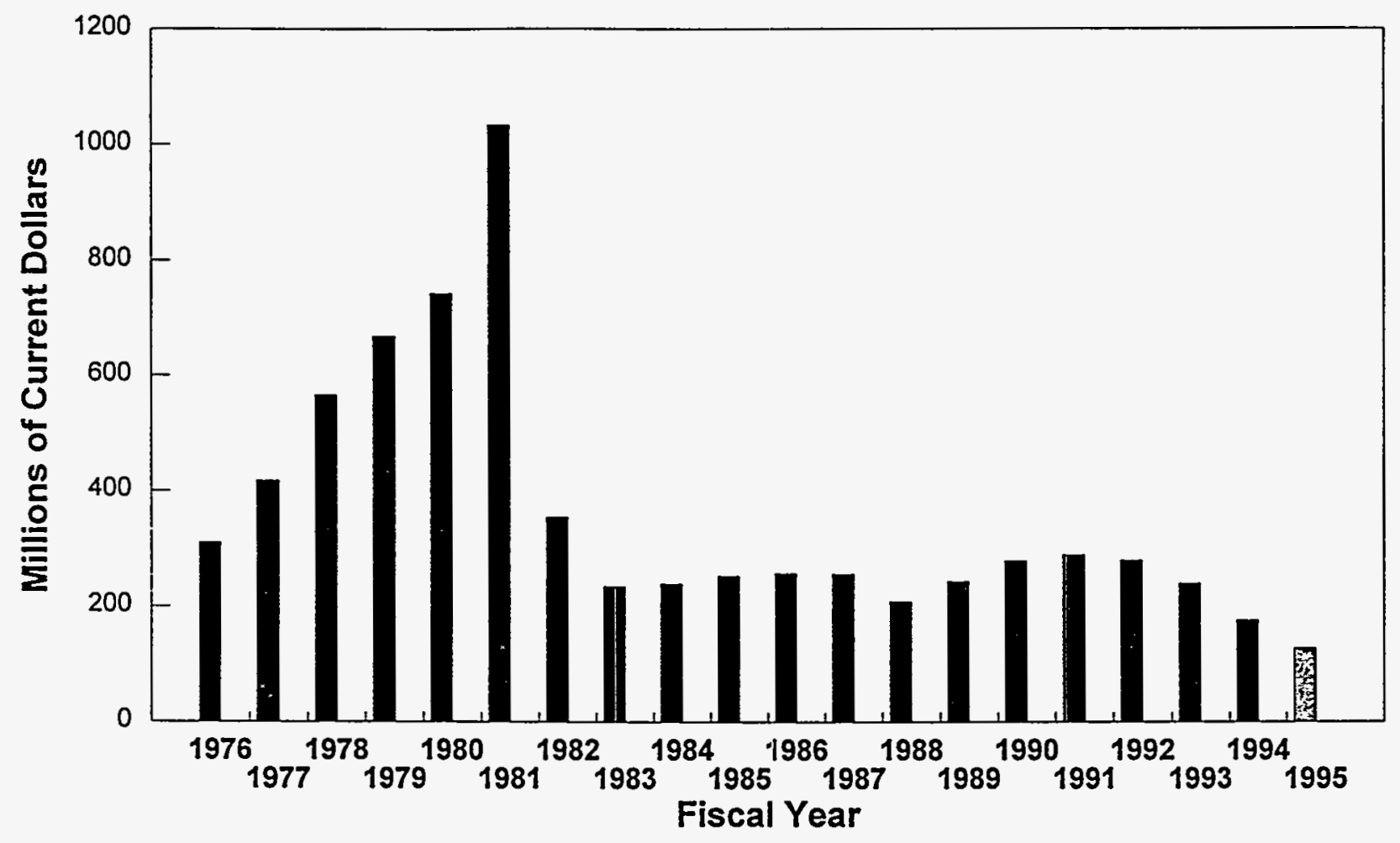

Figure 2-1 History of funding for coal R\&D under DOE's Office of Fossil Energy R\&D budget. Sources: DOE budget archives; DOE (1994a). ${ }^{a}$

${ }^{2}$ Data shown in Figure 2-1 for FY 1976 through FY 1994 represent congressional appropriations for coal-related FE R\&D in current dollars. The values shown do not include any adjustments, such as supplementals, rescissions, reprogrammings, etc., that took place after enactment of the appropriations bills. The FY 1995 number shown is the congressional budget request in current dollars. Budget data for FY 1976 through FY 1994 by specific program area are given in Appendix C. 


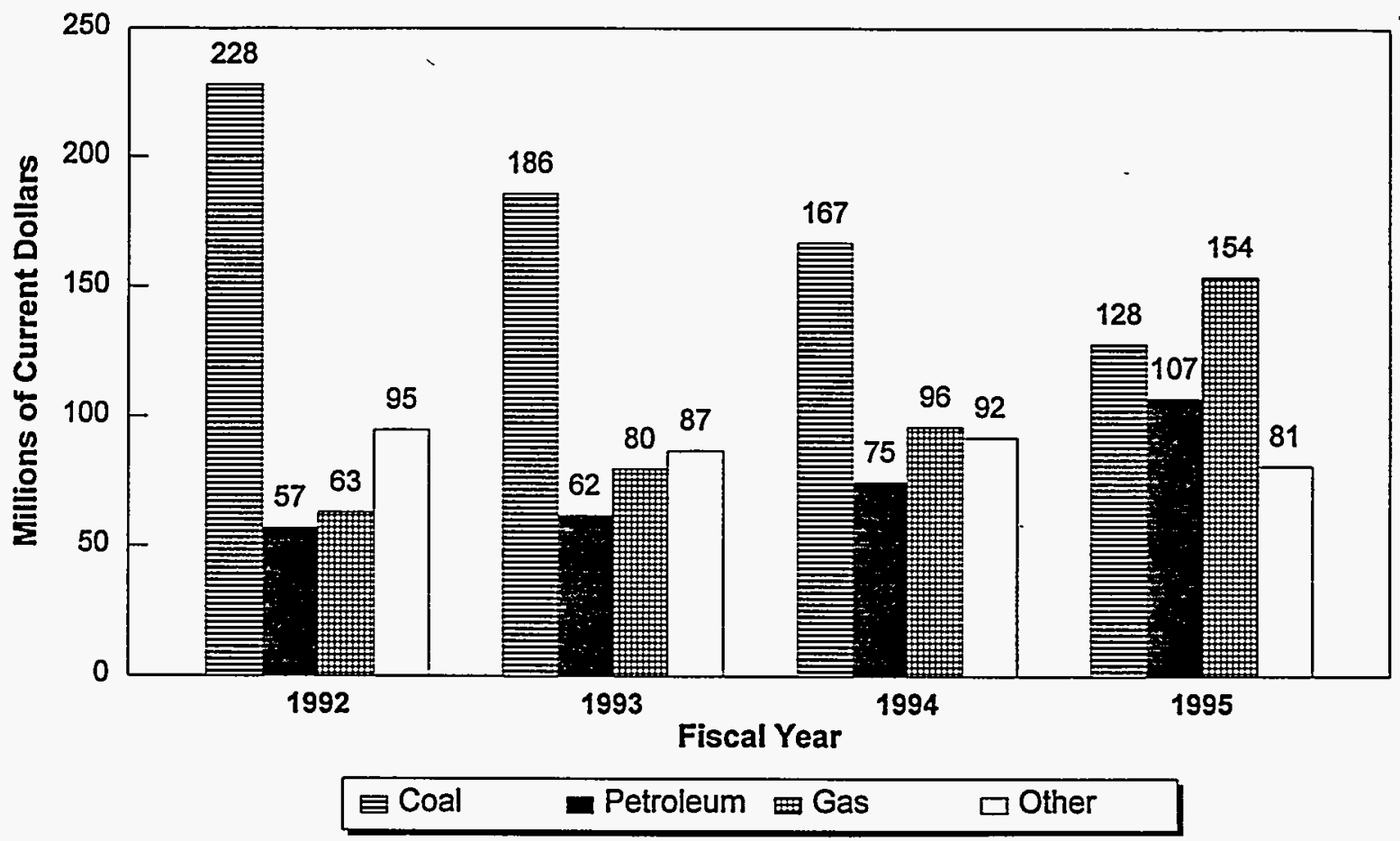

Figure 2-2 Recent budget trends for DOE's FE R\&D programs. Sources: DOE, 1993a, 1994a. 
Table 2-1 Fossil Energy Coal R\&D Program Budget (millions of current dollars appropriated)

\begin{tabular}{|c|c|c|c|c|}
\hline Program Element & FY 1992 & FY 1993 & FY 1994 & $\begin{array}{l}\text { FY } 1995 \\
\text { (request) }\end{array}$ \\
\hline \multicolumn{5}{|l|}{ Advanced Clean Fuels } \\
\hline Coal Preparation & 15.1 & 9.9 & 11.3 & 5.5 \\
\hline Direct Liquefaction & 19.4 & 15.7 & 11.4 & 5.6 \\
\hline Indirect Liquefaction & 13.7 & 16.2 & 9.1 & 7.6 \\
\hline Advanced Research and Environmental Technology & 7.1 & 5.9 & 5.2 & 0.8 \\
\hline Systems for Coproducts & 4.3 & 1.5 & 3.9 & 0.6 \\
\hline Subtotal & 59.6 & 49.2 & 40.9 & 20.1 \\
\hline \multicolumn{5}{|l|}{ Advanced Clean/Efficient Power Systems } \\
\hline Advanced Pulverized Coal-Fired Power Plant & 8.2 & 9.1 & 9.1 & 7.6 \\
\hline Indirect-Fired Cycle & 24.6 & 12.1 & 14.4 & 11.9 \\
\hline High-Efficiency IGCC ${ }^{2}$ & 18.0 & 19.5 & 27.2 & 28.1 \\
\hline High-Efficiency PFBC ${ }^{b}$ & 18.6 & 18.5 & 24.1 & 20.4 \\
\hline Advanced Research and Environmental Technology & 26.8 & 21.7 & 17.8 & 13.4 \\
\hline Magnetohydrodynamics & 39.9 & 29.9 & 4.8 & - \\
\hline Fuel Cells & 51.0 & 51.1 & - & - \\
\hline Subtotal & $\begin{array}{c}187.1 \\
{[136.1]^{\mathrm{d}}}\end{array}$ & $\begin{array}{c}161.9 \\
{[110.8]^{\mathrm{d}}}\end{array}$ & 97.4 & 81.4 \\
\hline \multicolumn{5}{|l|}{ Advanced Research and Technology Development } \\
\hline Coal Utilization Science & 4.0 & 1.9 & 3.1 & 3.1 \\
\hline Materials and Components & 9.2 & 8.9 & 10.7 & 7.8 \\
\hline Technology Crosscut & 10.8 & 9.6 & 9.3 & 9.4 \\
\hline University/National Laboratory Coal Research & 5.9 & 5.9 & 5.9 & 6.0 \\
\hline Subtotal & 29.9 & 26.3 & 29.0 & 26.3 \\
\hline TOTAL & $\begin{array}{c}276.6 \\
{[225.6]^{d}}\end{array}$ & $\begin{array}{c}237.4 \\
{[186.3]^{\mathrm{d}}}\end{array}$ & 167.3 & 127.8 \\
\hline
\end{tabular}

antegrated gasification combined-cycle.

'Pressurized fluidized-bed combustion.

'The fuel cell activity was transferred from the coal program to the natural gas program in FY 1994. Fuel cell budgets are $\$ 51.8$ million for FY 1994 and $\$ 67.8$ million for FY 1995 (request).

${ }^{d}$ Excluding fuel cells.

Sources: DOE (1993a, 1994a). 
Overview of U.S. Department of Energy Programs and Planning

Table 2-2 Authorized Funding for the CCT Program (millions of current dollars)

\begin{tabular}{lrrrrr}
\hline Solicitation Round & FY 1986-FY 1994 & FY 1995 & FY 1996 & FY 1997 & Total \\
\hline CCT-I & 398 & & & & 398 \\
CCT-II & 575 & & & & 575 \\
CCT-III & 575 & & & 575 \\
CCT-IV & 450 & 100 & 50 & 600 \\
CCT-V & 225 & 275 & 100 & & 600 \\
Total & 2,223 & 375 & 150 & 0 & 2,748 \\
\hline
\end{tabular}

Source: DOE (1994c). 
Table 2-3 Strategic Objectives of DOE's Advanced Power Systems Program

\begin{tabular}{lcccc}
\hline & \multicolumn{4}{c}{ Period } \\
\cline { 2 - 5 } Objective & 2000 & 2005 & 2010 & 2015 \\
\hline Efficiency $^{\mathrm{a}}$ (percent) & 42 & 47 & 55 & 60 \\
Emissions $^{\mathrm{b}}$ & $1 / 3$ & $1 / 4$ & $1 / 10$ & $1 / 10$ \\
Cost of energy & 10 to 20 percent lower than currently available pulverized \\
& \multicolumn{4}{c}{ coal technology } \\
\hline
\end{tabular}

${ }^{a} B a s e d$ on fuel higher heating value (see Glossary). A DOE presentation to the committee also noted $\mathrm{CO}_{2}$ reduction objectives of $24,32,42$, and 47 percent for each of the four periods, respectively, based on energy efficiency improvements (Feibus, 1993). All these values are calculated assuming a base plant efficiency of 32 percent.

${ }^{b}$ Current federal New Source Performance Standards (NSPS) apply to emissions of sulfur dioxide, oxides of nitrogen, and particulates from coal-based steam generators.

Source: DOE (1993b). 


\section{Trends and Issues for Future Coal Use}

The present chapter reviews those factors likely to influence coal use, especially U.S. domestic coal use, over the periods of interest to this study, namely, near-term (1995-2005), mid-term (2006-2020), and long-term (2021-2040) planning horizons. The introductory section on markets for coal and coal utilization technologies highlights the importance of coal to the U.S. economy and addresses international issues to the extent that they are likely to influence U.S. coal use and U.S. development of coal-based technologies. A major part of the chapter is devoted to a discussion of coal use for electricity generation, the single largest consumer of coal in the United States. Recent changes in the electric utility industry are considered, especially regarding the commercialization of new coal-based power generation technologies and opportunities for joint production of electricity and other products. Following a brief overview of projected U.S. electricity requirements, trends in the availability and use of competing energy sources for power generation are discussed. Issues associated with other uses of coal, namely, the manufacture of clean fuels and other products, are then addressed. Finally, the chapter discusses the environmental regulations affecting coal use.

\section{DOMESTIC AND INTERNATIONAL MARKETS}

\section{Overview of Coal Markets}

Coal is a major international commodity used primarily for generating electricity and producing coke for steelmaking. The first use is increasing steadily; the latter use is constant to slightly declining.

Coal-exporting countries can be divided into two classes. For the first group, including the United States, South Africa, Poland, and parts of the former Soviet Union, coal exports are a fraction of a substantial domestic market. Other countries mine primarily for export. The leading country in this class is Australia, with Colombia and Venezuela also increasing coal exports rapidly (IEA, 1993a). China is a special case: it is the world's largest coal producer, but almost all of its coal is consumed domestically (Doyle, 1987). However, with investment in transportation networks and some automation, China could quickly become a major force in international coal markets. Japan is the world's largest coal importer, while the fastest import growth is occurring in the rapidly developing Pacific Rim countries, especially Taiwan and South Korea (DOE, 1993a). 
In the United States, as elsewhere, coal production has a significant impact on the domestic economy. A recent study from the Pennsylvania State University notes that the direct contribution of coal production to the economy has a value of $\$ 21$ billion annually, while indirect contributions reach $\$ 132$ billion (Energy Daily, 1994).

Over the past 10 years, many changes have occurred in the U.S. coal industry. Although more coal is still produced in states east of the Mississippi River, coal production in the west has increased dramatically; in 1988 Wyoming surpassed Kentucky as the largest producing state. This shift in coal production initially was a result of changes in environmental regulation that favor low-sulfur Western coal. Subsequent factors have been the competitive cost of western coal and a lower cost for its rail transport to markets traditionally served by eastern coal. These trends are expected to continue, with environmental constraints on coal combustion becoming more stringent.

Transportation costs are more generally a critical determinant of the competitiveness of coal from different sources. On the Gulf and Atlantic coasts of the United States, South American coals are very competitive with U.S. coals on a delivered price basis. For example, Colombian coal currently is $\$ 3$ to $\$ 6 /$ per metric ton cheaper than U.S. coals (Coal Week International, 1994). About 10 percent of the coal used in the United States during the first decade of the next century will likely be imported (EIA, 1994a).

Another change in the industry has been the continued decrease in the price paid for coal at the mine. For mines producing 10,000 tons per year or more, the average price at the mine decreased in 1992 for the tenth straight year, to $\$ 21.03$ per ton (NCA, 1993a). ${ }^{1}$ This trend of decreasing coal prices is expected to persist for the near term, keeping coal a relatively low cost energy source for the United States.

Coal exports contribute significantly to the U.S. balance of payments. Of the total 1992 U.S. coal production of 998 million tons, 103 million tons were exported, primarily to Europe (57 percent), Asia (20 percent), and North America (15 percent) (IEA, 1993a). Coking coal exports amounted to $\$ 2.7$ billion and steam coal to $\$ 1.5$ billion. Most U.S. exports are metallurgical coals, purchased because of their high product quality and consistency, which are important parameters in making coke. However, coke production worldwide is decreasing, as environmental regulations and newer technology change the way steel is produced and as other materials are substituted for steel. Despite increasing international markets for steam coal, this sector of the U.S. export market is expected to remain flat or decrease, because U.S. coal is not competitive on a delivered-price basis with South American and South African coals in Europe and the Middle East, nor with Australian and Indonesian coals in Asia. For example, U.S. coal with an energy content of $12,000 \mathrm{Btu} / \mathrm{lb}$ is delivered to Rotterdam from Baltimore at a price of $\$ 1.51 / 10^{6} \mathrm{Btu}$, while similar coal from Colombia is delivered at $\$ 1.31 / 10^{6}$ Btu and from South Africa at $\$ 1.27 / 10^{6} \mathrm{Btu}$ (Coal Week International, 1993). These and other competitor producing countries are expanding their coal exporting capability. Thus, exporting U.S. clean coal technology will probably not open any significant new markets for U.S. steam coal.

\footnotetext{
${ }^{1}$ Unless otherwise noted, all "tons" referred to in the text are short tons (i.e., 2,000 lb or 0.91 metric tons).
} 


\section{Markets for Coal Utilization Technology}

The most important international markets for coal utilization technologies are for electricity generation. Two major market components have been identified, namely, the construction of new generating capacity and the retrofit and rehabilitation of existing plants (DOE, 1993a). More than half of the new capacity market will be in China, where projected capacity additions are approximately three times those of South Asia, the second largest market. China's need for new capacity through 2010 is more than four times that of all the industrialized countries combined. The world retrofit market, which is driven largely by environmental considerations, is about 25 percent larger in total size than the market for new capacity. About 45 percent of the retrofit market lies in developing countries, notably China. Significant markets also exist in Eastern Europe and the former Soviet Union (DOE, 1993a).

The demands for new and retrofit capacity represent potentially large export markets for U.S. technology. Many of the advanced power generation and environmental control technologies being developed under DOE's CCT program might achieve the two principal market requirements: high efficiency and minimal environmental impacts. It is very difficult, however, to project the extent of U.S. participation in these international markets. Determining factors will include the effectiveness of foreign competition, the rate of industrialization in the less developed countries, the economic balance between coal costs and the capital costs of new technology, and the environmental constraints within the purchasing countries.

Environmental constraints will have some of the greatest impacts on international sales of coal-related technology. These environmental constraints will depend on the degree of industrialization and urbanization. Urbanization is accompanied by environmental problems so acute that even developing countries strained for capital resources cannot ignore them. In Turkey, for example, which is seeing a massive population shift from rural to urban areas, in major cities there is a shift from indigenous coal to imported natural gas as a home heating fuel, and scrubbers for sulfur dioxide removal are being retrofitted on power plants that use highsulfur, usually low-rank, local coal. In China coal gasification is being used to ameliorate some critical instances of pollution (Coal and Synfuels Technology, 1993). The motivation to reduce coal-related pollution may be domestically driven or may be a response to environmental requirements imposed by aid donors and international financial institutions. The World Bank now considers environmental impacts as a primary factor in evaluating proposed projects (DOE, 1993b).

Other major factors affecting coal technology markets will be the balance between the costs of mining and transporting coal and the higher capital costs of cleaner, more efficient plants. Where coal is abundant, mining and transportation costs are low, and environmental requirements are minimal, there will be little driving force to use the more expensive technologies. Such circumstances generally hold now in China. As environmental constraints develop or fuel prices increase, there will be incentives to use more efficient and cleaner technologies. Indeed, China, with its abundant coal reserves, rapidly industrializing economy, and large population, is undoubtedly the largest potential market for U.S. clean coal technology over the long term. For the near term, however, new power plants in China will most likely use well-demonstrated technology and cheap Chinese coal to produce low-cost power. 
Domestic markets for coal utilization technologies are discussed in the remaining sections of this chapter, with emphasis on opportunities and requirements for electricity generation.

\section{COAL USE FOR DOMESTIC ELECTRICITY GENERATION}

Electric power generation is by far the largest market for coal in the United States, representing over 80 percent of annual coal consumption. Assessing current and projected electricity demand is thus essential to understanding the future role of coal and the scope of an appropriate RDD\&C program. The following section reviews the changing structure of the U.S. electric utility industry, current projections of future electricity demand, and the outlook for competing sources of energy for power generation over the time periods of interest for this study.

\section{Changing Structure of the Electric Utility Industry}

The electric utility industry has been subject to extensive price and entry regulation virtually from its beginning almost a century ago. Like other formerly heavily regulated industries, such as transportation, telecommunications, and natural gas, the electric utility industry has seen notable changes of regulatory structure and practice in recent years.

The Public Utility Regulatory Policy Act of 1979 (PURPA) and subsequent regulation and legislation, at both state and federal levels, have permitted nonutility generators (NUGs) to sell power to the transmission grid. PURPA provided the first opportunity since the development of the modern regulatory system for entry into the utility franchise by requiring electric utilities to purchase power offered by cogenerators, small power producers, and other qualifying facilities when the price of purchased power was below the utility's own avoided cost. Independent power producers (IPPs) were excluded from the provisions of PURPA, but later changes, such as enactment of EPACT that allows utilities and non-PURPA generators to compete on a wider scale in the wholesale power market, permitted and even encouraged electric utilities to acquire additional capacity and power from NUGs without regard to PURPA's qualification requirements (Harunuzzaman et al., 1994). Increasingly, access to the transmission and distribution network is being proposed for a variety of currently captive customers. Although there are many problems to be resolved, deregulation of the electric utility industry is expected to continue, to probably intensify, and to become one of the dominant strategic concerns of electric utility managers.

For this report the question at issue is how the industry's deregulation should shape DOE's coal program. The principal areas of concern appear to be the power generation industry's ability to develop and adopt promising new technology and the availability of electricity produced jointly with other products, as in cogeneration of power and steam. 
The electric utility industry's former regulatory structure provided a highly favorable environment for introducing new technology: the return of prudently incurred costs was allowed, reducing commercialization risks. The efficiency of conventional coal-fired power plants increased markedly from the early 1900s until the 1960s without the benefit of significant federal R\&D funding. Beginning in the 1960s, the industry commercialized nuclear power based on federally funded R\&D. Since the early 1970 s the industry has also funded significant R\&D through the EPRI, with most members' contributions incorporated into the rate structures approved by regulatory commissions.

As regulatory structures loosen and competition intensifies, new entrants and lessprotected utilities may be unwilling or unable to accept the risks of commercialization or to fund industrywide R\&D. In this regard the power generation industry differs markedly from the pharmaceutical and telecommunications industries, for example, largely because of the nature of its product. The influence of increasing competition in the electric utility industry can already be observed in the reliance on NUGs for additional increments of capacity and in the shift of EPRI's focus toward activities of more short-term benefit to its members. A recent report from the National Regulatory Research Institute (Harunuzzaman et al., 1994) notes that the technical and financial risks inherent in adopting innovative generation technologies may bias technology choices in favor of conventional options. As a result of these trends, the future development and implementation of advanced power generation technologies will likely become increasingly dependent on federal funding of R\&D and on federal participation in commercializing new technology, at least in the near term. Federally supported R\&D is unlikely to be an adequate substitute for industry-funded R\&D over all timeframes. However, in the near term some federal support may facilitate more rapid development of technological solutions to problems of national importance, such as reducing the environmental impact of coal-based power generation as required by EPACT, Title XIII, Section 1301 .

\section{The Availability of Coproducts}

Under traditional regulation, electric utilities specialized in, and had a monopoly on, the production and distribution of electricity. Sizeable economies of scale were realized under this arrangement, but it did not encourage the capture of economies that result from coproducing electricity and other products, such as steam. Electric utilities did provide steam to some customers but generally only in the centers of large and usually older cities because of the economics of distributing steam. In most cases customers who needed steam for industrial processes produced their own. They might also generate electricity, but for a variety of reasons, including regulation, they could not sell excess electricity to the local electric utility.

The recent changes in the electric utility industry sketched above have created the opportunity to realize economies where electricity, or the fuels to generate electricity, are the by-product of some other industrial process. These processes typically operate at a smaller scale than the conventional electric utility generating unit, and this feature has meshed well with smaller-capacity additions demanded by recent slower electricity growth. The joint production 
of electricity and steam has been the main beneficiary of these changes to date. Coproduct systems are discussed further in Chapter 6 . The gas turbine combined-cycle systems now being installed that use natural gas as a fuel also offer opportunities to use clean coal-based gases, either as an integral part of the power generation system or obtained as a fuel from a separate supplier.

\section{Projected Electricity Requirements}

Table 3-1 gives growth rates observed and projected by the Energy Information Administration (EIA) for U.S. electricity demand from 1960 through 2010. According to the most recent EIA projections (EIA, 1994a), electricity demand will grow 1.0 to 1.5 percent per year to 2010, while the gross domestic product over the same period will grow 1.8 to 2.4 percent annually, for "low" and "high" economic growth cases. The decrease in electricity demand growth relative to growth in the gross domestic product through 2010 is expected to result primarily from energy efficiency improvements associated with demand-side management and compliance with the directives of EPACT. The industrial sector is the fastest-growing demand sector in the EIA projections.

Alternative estimates from Data Resources, Inc. (DRI)/McGraw-Hill suggest that the trend in electric demand growth will average 2.0 percent per year from 1993 to 2010, during which time there will be a 2.3 percent annual increase in the gross domestic product (Makovich and Smalley, 1993). These projections assume a smaller impact of demand-side management on electricity demand than the EIA projections.

EIA projections of new capacity needs to meet new demands and to offset plant retirements are summarized in Figure 3-1 (EIA, 1994a). These new capacity requirements are in addition to the augmentation of existing resources through electricity imports and through plant life extension and repowering (see below). Between 1990 and 2010, utilities are expected to install $110 \mathrm{GW}$ of new capacity in the EIA reference case but retire $60 \mathrm{GW}$, for a net capacity increase of $50 \mathrm{GW}$. In response to legislative changes aimed at making electricity production more competitive, NUGs and cogenerators are expected to add an additional $73 \mathrm{GW}$, accounting for a large share (40 percent) of total new capacity additions of $183 \mathrm{GW}$ over the forecast period. Figure 3-1 shows that new capacity will be needed particularly between 2000 and 2010, Guring which time repowering and other options will be insufficient to meet increased demand. The surplus capacity of the 1980s still persists in some areas, and it will probably not be completely employed in many areas until the turn of the century. Thus, projected capacity additions lag projected increases in demand (Makovich and Smalley, 1993).

Table 3-2 compares several forecasts of total U.S. generating capacity in 2000 and 2010. Detailed comparison of these estimates is difficult because of differences in the reporting of generating capacity, such as the inclusion or exclusion of cogeneration capacity. However, all the projections for 2010 indicate a need for significant generating capacity increases compared with the 1992 value of 742 GW (EIA, 1994a). An energy forecast that relies less on historical trends and more on market forces and rapid deployment of new, high-efficiency technologies projects a total generating capacity in 2010 of 712 GW (The Alliance to Save Energy et al., 
1992). Despite these different assumptions, coal is still projected to be a major energy source for power generation in 2010.

The additional generating capacity does not necessarily require the construction of new plants. Repowering, broadly defined to include any activity that stabilizes or reverses the ageinduced deterioration of generating units (Makovich and Smalley, 1993), can result in improved efficiency and increased generating capacity at less than replacement cost. According to some projections, an emphasis on repowering-including performance optimization, component replacement, component refurbishment, life extension, and/or unit upgrading-is likely over the next decade (Makovich and Smalley, 1993). This forecast trend is consistent with the low number of scheduled power plant retirements reported to the North American Reliability Council for the period through 2003. Although a large number of the fossil-fuel-fired steam plants operating today are nearing the end of their nominal life ( 40 to 45 years), utilities appear to be planning to continue using them for the foreseeable future (EIA, 1994b).

The choice of technologies to meet additional generating capacity requirements depends on both peak load and baseload needs. Peak load is the maximum load during a specified period of time, whereas baseload is the minimum amount of power required during a specified period at a steady state. According to EIA projections (EIA, 1994a), there will be a need through 2010 for flexible generating technologies, such as gas-fired or oil- and gas-fired combined-cycle and combustion turbine systems, designed primarily to meet peak and intermediate load requirements but able to meet baseload requirements as needed. Peak load requirements are anticipated to increase from $589 \mathrm{GW}$ in 1994 to $804 \mathrm{GW}$ in 2010 (Makovich and Smalley, 1993).

\section{Energy Sources for Power Generation}

How much of the projected demand for electricity is likely to be supplied by coal? This section addresses the major competing sources of energy for electric power generation over the time periods of interest for this study. More extensive discussions can be found in the various references cited throughout this section.

\section{Coal}

The coal base of the world is large, some 1,145 billion tons. The top two producing countries are China and the United States. The U.S. demonstrated reserve base (DRB) of coal is now estimated to be 474 billion tons (EIA, 1992). The DRB is the amount of coal that can potentially be mined by surface or underground methods. The amount of coal that can be extracted economically using available technology, taking into consideration the laws, regulations, economics, and usages that affect coal production, is the recoverable portion of the DRB; EIA currently uses an estimate of 56 percent of the DRB, which equals 265 billion tons. Estimates of recoverable reserves vary with location. They are typically about 60 percent of $\mathrm{DRB}$ for eastern underground mines and 90 percent of DRB for western surface mines (NCA, 
1993b). ${ }^{2}$ Resource limitations are not expected to be important within the time horizon considered in this study.

All projections for U.S. coal consumption indicate that coal will continue to be a major source of fuel for electricity generation up to and beyond 2010. A range of forecasts is shown in Table 3-3. Estimates of coal's share of the power generation market in 2010 range from 45 to 58 percent, slightly lower on average than the current value of 56 percent. New coal-steam units are expected to account for 25 percent $(42 \mathrm{GW})$ of all new capacity additions through 2010, with approximately three-fourths of the new coal-fired capacity coming online after 2000 (EIA, 1994a). This $42 \mathrm{GW}$ of new coal capacity is equivalent to 140 new power plants in the 300-MW size range.

\section{Natural Gas}

In recent years natural gas has become the fuel of choice for new capacity additions because of its lower prices and lower capital investment requirements and more stringent environmental rules. While domestic gas resources are adequate to support this trend in the near term, the depletion of domestic gas resources will likely result in their reduced availability and higher prices within the time period considered in this study.

Estimates of the remaining technically recoverable domestic natural gas resource provide some perspective on the future use of natural gas for power generation. A comparison of such estimates has been prepared by the Potential Gas Agency at the Colorado School of Mines (Potential Gas Committee, 1993). Assuming current technology and unspecified prices in the lower 48 states, and varying assumptions on access to potential gas fields, the estimates ranged from a low of 650 trillion cubic feet (Tcf), the value used in formulating the 1991 National Energy Strategy, to the Gas Research Institute (GRI) 1993 estimate of 1,100 Tcf. The National Petroleum Council estimate of $870 \mathrm{Tcf}$ falls between these extremes. Table 3-4 gives National Petroleum Council estimates of the effect of wellhead price on the recoverable resource.

Dividing the total amount of gas by the current annual consumption provides a rough measure of the time before depletion, assuming constant consumption (see Table 3-4). The actual time will depend on consumption rate, which is expected to rise for the next decade and then decrease as finding and production costs increase with progressive resource depletion. Major technological advances would extend the period of economic gas production.

EIA and GRI projections for the supply of natural gas and its disposition (see Table 3-5) indicate that domestic production and imports will increase to meet demand. The increase in domestic production will require the use of new gas recovery technology, which will account

\footnotetext{
${ }^{2}$ The fraction of the DRB that is recoverable has recently been estimated for the Central Appalachian coal mining region, which encompasses the states of Kentucky and West Virginia. The study revealed that only 50 percent of the reserve base was potentially recoverable because of various mining, environmental, social, economic, and regulatory factors (Carter and Gardner, 1993). Considering additional restrictions in the form of coal mining factors, recovery factors, and economic factors further reduced the economically recoverable coal resource to between 4.2 and 26.4 percent of the DRB (Rohrbacher et al., 1993).
} 
for 29 percent ( 7.5 quads $^{3}$ ) of the 2010 gas supply. By 2010, gas imports will have risen to approximately 15 percent ( 3.8 quads) of the total supply, and power generation will consume between 4 and 5 quads of gas, or approximately 18 percent of the supply.

Projections for delivered gas prices for electric utilities are summarized in Table 3-6. Both EIA and GRI projections show these prices increasing, EIA more so than GRI. As natural gas prices increase, there will be a point at which coal-derived electricity is more economical. For greenfield natural gas-fired combined-cycle units versus coal gasification combined-cycle units, this crossover price is in the range of $\$ 4.00$ to $\$ 5.00 /$ million Btu. ${ }^{4}$ The crossover gas price depends on a number of factors, such as the capacity factor at which the power-generating unit is operated, the lifetime of the investment, and the delivered price of coal. The price range just given represents capacity factors between 50 and 70 percent, coal prices between $\$ 1.00$ and $\$ 1.60 /$ million Btu (between $\$ 21.0$ and $\$ 33.6$ per ton), and a power plant lifetime of 30 years. A higher-capacity factor may apply to advanced coal plants; this would decrease the crossover price, while a shorter amortization period would raise it.

Similar analyses can be made for repowering applications using coal-fueled integrated gasification combined-cycle (IGCC) or pressurized fluidized bed combustion (PFBC) technology. Under the same assumptions as before, coal-based systems become economical when gas prices reach $\$ 3.50$ to $\$ 4.50 /$ million Btu. ${ }^{5}$ The gas price projections in Table 3-6 suggest that advanced coal technology will become more economical than gas for both repowering and greenfield applications between 2005 and 2010.

Construction of a power plant in 2005, for example, will involve assessing the likelihood of increasing gas prices and decreasing supply during the 30-year (or longer) plant lifetime. In addition, extended growth in high-priority residential and commercial gas consumption is anticipated (EIA, 1994a). Thus, the EIA projection that new electric generating capacity will depend primarily on coal after 2000 seems well founded.

\section{Liquefied Natural Gas}

In considering the outlook for natural gas in the United States, attention must also be given to liquefied natural gas (LNG). Small amounts of LNG are presently imported into the United States. More importantly, there are huge, low-cost reserves of natural gas in the Pacific Basin and Middle East that, when liquefied, can be transported across oceans. Thus, the cost at which LNG can be imported operates as a limit on the domestic price of natural gas and on the price that would be paid for gas produced from domestic coal.

The process through which natural gas is liquefied, transported at cryogenic temperatures, and regasified is unique and costly and was economic only when domestic gas prices were higher than currently. Several LNG facilities were built on the East and Gulf coasts of the United States

\footnotetext{
${ }^{3}$ One quad $\left(=10^{15} \mathrm{Btu}\right)=0.97 \mathrm{Tcf}$, assuming an average Btu content for natural gas of $1,028.4$ per cubic foot.

${ }^{4}$ Personal communication from N.A. Holt to G.T. Preston and J.H. Wootten, April 1994.

${ }^{5}$ Ibid.
} 
during the 1970s. At the time, domestic natural gas availability was limited, and rolled-in pricing permitted the high LNG cost to be cross-subsidized by low-priced, regulated gas. ${ }^{6}$ However, LNG projects in the United States were abandoned once the domestic natural gas price decreased as a result of deregulation, and new proposals by potential exporters have not succeeded. An advantage of LNG for power generation is that it can be stored and used to meet peaking requirements without the need to construct larger pipelines.

In view of these considerations, LNG will not figure as an economic source of energy for power generation until natural gas prices rise to approximately $\$ 5 / 10^{6} \mathrm{Btu}$. In the United States, coal gasification and other options should be economic at lower prices.

Oil

If crude oil prices were to fall to $\$ 12 / \mathrm{bbl}$ or less, coal might find a competitor for power generation in low-sulfur residual or distillate fuel. Although world reserves of crude oil are not as large as those of natural gas, they are still very large, and the cost of landing crude oil in the United States is substantially less than comparable costs for LNG. Distillate can be used in combined-cycle power generation systems as a substitute for natural gas, LNG, or coal-derived gas. The use of cheaper residual fuel is not currently feasible in turbines, but at a low enough price (less than $\$ 1.50 / 10^{6} \mathrm{Btu}$, or approximately $\$ 9.50 / \mathrm{bbl}$ ) it could displace coal in some existing boilers, as it did in the past.

\section{Nuclear Power}

Nuclear power accounted for 21 percent of U.S. electric power generation in 1993 and 14 percent of total U.S. generating capacity. However, no new commercial orders for U.S. nuclear power plants are anticipated until well after 2000. Nonetheless, recognizing the future attractiveness of electricity from nuclear fission, in part because of the potential for simpler, more economical nuclear plants, U.S. suppliers, nuclear utilities, the federal government, and EPRI are supporting the development of advanced light-water reactor designs (both evolutionary $1,300-\mathrm{MW}$ units and mid-size $650-\mathrm{MW}$ units), to be available for order by the mid-1990s. Modular high-temperature gas reactor and advanced liquid metal reactor designs are under development. Although these designs may be available as early as 2005 , their adoption is uncertain. While concern over greenhouse gas emissions could increase the attractiveness of nuclear power plants relative to coal, the economic and environmental issues associated with plant operation and waste disposal are likely to impede any significant growth of nuclear capacity

\footnotetext{
${ }^{6}$ "Rolled-in pricing" is the term used for the practice of purchasing high-cost gas to mix with low, pricecontrolled gas. The resulting average price was not prohibitively high, and natural gas continued to be in demand. Also, there was an apparent market for the high-cost supplies. The system worked only so long as there was a pricecontrolled "cushion" of low-cost supplies. With price controls gone, all gas is now priced at the market, and there is no longer an ability to mix high- and low-cost gas.
} 
in the near to mid term. In the committee's base scenario, significant deployment of new nuclear power plants is unlikely until after 2020 .

Considering installed and anticipated nuclear power plants in the United States and worldwide, there is no prospect of a uranium shortage before 2020. However, a significant expansion of nuclear power thereafter could challenge accessible uranium supplies. If supply constraints forced up uranium prices after 2020 , the continued use of nuclear-based electricity would require technology development on fast breeder reactors and fusion reactors. The support of further development and use of nuclear power in the United States and worldwide will depend on growth in overall electricity demand, regulatory evolution, the direction of the global climate change debate, and resolution of public concerns with operational safety and waste disposal. Policy actions that increase the cost of fossil fuel use would make nuclear power more competitive.

\section{Renewable Energy}

Most electricity from renewable resources in the United States comes from hydroelectric power, which in 1993 accounted for about 10 percent of installed generating capacity and 9 percent of electricity generation. Other renewable sources accounted for 0.3 percent of electricity generation in 1993: geothermal, biomass wastes (almost all forest industry, with a small contribution from municipal solid waste), modest but growing amounts from wind turbine "farms," and distributed high-value, high-cost, solar photovoltaic power.

Cost reductions in renewables have resulted from persistent R\&D, field experience, and manufacturing automation made possible through federal and private investments. EPRI has projected cost ranges for wind, photovoltaic, and biomass, assuming favorable locations (Table 3-7). These data indicate likely decreases in cost over the next 15 years, together with changes in the relative economics of different renewable sources. Although wind and biomass may be attractive for specific applications in favorable locations, it is clear that renewables could not meet energy demands across the economy as a whole (Preston, 1994). Many utilities look at renewable technologies as a strategically valuable set of contingency options if prices rise substantially or fossil fuel use is curtailed. For example, policy actions to tax emissions would make renewables more competitive. While renewable energy sources are expected to gain a larger share of the U.S. power generation market (16 percent by 2010 , according to EIA, 1994a), they are not expected to become dominant sources of bulk power generation during the periods addressed in this study.

\section{COAL USE FOR LIQUID AND GASEOUS FUELS}

While electric power generation is expected to be the principal use of coal in the nearto mid-term periods, liquid and gaseous fuels derived from coal have the potential to compete with natural gas- and petroleum-based fuels in the mid and long term. The outlook for coalderived liquid and gaseous fuels is discussed in Chapter 6. 


\section{Resource Base for Petroleum and Bitumen ${ }^{7}$}

Liquid hydrocarbon resources can be classified on the basis of viscosity as conventional petroleum, heavy oil, and tar (or bitumen). ${ }^{8}$ Because of its low viscosity, petroleum tends to accumulate in large pools with natural gas and is relatively cheap to produce, with high resource recovery. In general, it contains less sulfur than the heavier hydrocarbons and can be refined to specification fuels more easily and cheaply than heavy oils and tars. While large resources of heavy oils and tars have been found, current production is restricted by the higher production and refining costs. Estimates of world and U.S. petroleum resources are shown in Table 3-8.

Petroleum finding and production costs for major producers are currently well below the international price, which includes profit taken by producing countries and by private investors, and is the result of an extremely complex combination of economic and political factors. As lowcost resources are depleted and production costs rise, the trading cost can be expected to rise.

In addition to conventional petroleum, there are substantial resources of heavy oil and bitumen $^{9}$ (Riva, 1991). The total world resource for heavy oil is estimated to be 600 billion bbl (equal to 35 percent of the conventional petroleum resource). About 50 percent of the heavy oil resource occurs in Venezuela and about 30 percent in the Middle East. The total resource for tar sands is approximately 3,500 billion bbl, but only 5 to 10 percent of this amount is currently considered to be economically recoverable. Here Canada is dominant, with 75 percent of the world total. Both heavy oil and bitumens require rnore costly production and refining than conventional petroleum and are not competitive with petroleum at current prices.

To compete with coal for power generation, heavy oils and bitumen would require pollution control similar to that required for coal, because of their high sulfur and metals content. To compete with coal at approximately $\$ 1.4 /$ million Btu, ${ }^{10}$ the delivered price of tars would need to be about $\$ 9 / \mathrm{bbl}$ or less. The above considerations support the assumption that unrefined tars and heavy oils will not displace a significant amount of coal for power generation in the foreseeable future.

${ }^{7}$ The resource base for natural gas was discussed above in the context of fuels for power generation.

${ }^{8}$ Defining viscosities are as follows: conventional petroleurn, less than 100 centipoise (cp); heavy oil, 100 to $10,000 \mathrm{cp}$; tar or bitumen, greater than $10,000 \mathrm{cp}$.

${ }^{9} \mathrm{Heavy}$ oil is defined as crude oil with an American Petroleum Institute gravity between $10^{\circ}$ and $20^{\circ}$ and viscosity between 100 and 10,000 cp. (American Petroleum Institute gravities are expressed in degrees and the specific gravity of water is defined as $10^{\circ}$.) Bitumen is more viscous and dense and is produced by mining.

${ }^{10}$ Based on projected minemouth price in 2010 of $\$ 30.9 /$ ton (EIA, 1994a) and Btu content of approximately 21 million Btu/ton. 


\section{OTHER USES OF COAL}

Coal still has some limited uses as a fuel outside the utility sector. Industry burns coal as a boiler fuel to raise steam. Limited use is also seen commercially in a variety of smaller boiler designs and some U.S. households continue to burn coal for space heating (EIA, 1994a). The primary use of coal not combusted directly is the production of metallurgical coke, which is both the fuel and the source of the reducing agent (carbon monoxide) in smelting various ores. The most important application of metallurgical coke is for reduction of iron ores in blast furnaces. EIA projections (reference case) of domestic coal consumption for these applications through 2010 are shown in Table 3-9. Data on coal use for electricity generation are included for comparison.

The only anticipated growth in demand (except for electricity generation) is industrial steam, due largely to growth in coal use for cogeneration in the chemical and food processing industries. The utilization of coke in the iron and steel industry is steadily diminishing for several reasons. First, improvements in blast furnace technology have significantly reduced the amount of coke required to produce a ton of iron. Second, there has been a major shift away from the use of blast furnaces toward the use of electric furnaces that use scrap steel. This change has reduced the demand for freshly produced pig iron or steel, reducing the need for coke. Third, the domestic iron and steel industry has suffered from competition with imported steel products, further reducing the domestic use of coke. No major upturn in the demand for metallurgical coke is foreseen for the periods of interest to this study.

The conversion of coal to metallurgical coke yields by-product hydrocarbon mixtures commonly known as coal tar. The value of coal tar as a source of chemicals or synthesis material for other products began to be recognized in the 1870s. For about 75 years, until the end of World War II, virtually the entire organic chemical industry was based on the utilization of coal tar. However, in the past half-century the organic chemical industry has derived substances principally from petroleum and natural gas, although coal tar is still a useful source of certain specialty chemicals, such as aromatic hydrocarbons with multiple fused aromatic rings, and coal tar pitch has some niche applications that cannot be satisfied by petroleum-derived pitch. When imported petroleum increases in cost, coal could once again become a source of chemical products, though any large market for chemicals based on coal is not likely to develop until it becomes practical to produce gaseous and liquid fuels from coal.

Coals have a variety of other specialized uses, most of them low-volume applications. For example, anthracites can be used as filter material for tertiary water treatment processes. Lignites have some ion-exchange behavior and can be used in some cases as inexpensive ionexchange "resins." These applications include wastewater treatment (e.g., the removal of chromium from electroplating wastes) and the concentration of ions, such as gold, in hydrometallurgy. Lignites can also be converted into so-called humic acids, which are useful soil amendments and can be nitrated to form fertilizers. There is also interest in converting coals, particularly those of high carbon content, into carbon-based materials, such as graphites. Most of the R\&D on these niche applications is taking place outside the United States. At the present time, no significant domestic markets for these applications are anticipated during the period addressed in this study. 


\section{ENVIRONMENTAL ISSUES FOR COAL USE}

Environmental concerns will have the greatest influence on future coal use for power generation in the industrialized countries (IEA, 1993b). In the United States, coal-fired power plants are already subject to a range of emission controls that will likely become increasingly stringent and wide ranging over the periods addressed by this study. Current and possible regulations governing emissions from coal-fired power plants are summarized below, along with information on the current status of control technologies. Appendix D reviews recent trends in U.S. regulatory policy and technology approaches to address environmental issues. Emissions control technologies are discussed in more detail in Chapter 7.

National ambient air quality standards for particulate matter, sulfur dioxide $\left(\mathrm{SO}_{2}\right)$, nitrogen dioxide $\left(\mathrm{NO}_{2}\right)$, and photochemical ozone were promulgated under the 1970 Clean Air Act to protect human health and welfare throughout the country. ${ }^{11}$ The primary drivers of technology innovation to control air quality over the past two decades have been pollutantspecific emission standards for new and existing air pollution sources, together with the ambient air quality standards, both promulgated by federal and state governments.

In contrast to ambient air quality standards, aimed at protecting human health, acid deposition regulations guard against cultural and ecological concerns, including damage to aquatic systems, forests, visibility, and materials. Anticipation of acid rain controls was the main factor motivating $\mathrm{SO}_{2}$ and nitrogen oxides $\left(\mathrm{NO}_{x}\right.$, a mix of $\mathrm{NO}$ and $\mathrm{NO}_{2}$ ) control technology development during the 1980s. The acid deposition provisions of the 1990 Clean Air Act amendments (CAAAs) established for the first time an absolute cap on total U.S. $\mathrm{SO}_{2}$ emissions, with provisions for emissions trading to achieve the required overall reduction in utility emissions most cost effectively. A reduction in $\mathrm{NO}_{\mathrm{x}}$ emissions was also mandated, although no cap on total emissions was established.

Significant progress has been made over the past decade in the capability of commercial systems to reduce $\mathrm{SO}_{2}, \mathrm{NO}_{x}$, and particulate emissions from pulverized coal-fired power plants. Emissions trends for a new pulverized coal power plant burning medium-sulfur coal are shown in Figure 3-2. Air pollution control devices today achieve emission levels well below federal NSPS. The most efficient wet scrubbers reduce $\mathrm{SO}_{2}$ emissions to about one-fourth to one-sixth of NSPS requirements (98 percent control). The most efficient commercial systems yield particulate emissions of about one-half to one-quarter NSPS levels (99.9 percent control). U.S. technology for power plant $\mathrm{NO}_{\mathrm{x}}$ control has focused on combustion modification methods that currently reduce emissions to about one-half to two-thirds of NSPS levels (50 to 60 percent control). In Japan and Germany, postcombustion controls achieving up to 80 percent $\mathrm{NO}_{x}$ reduction (about one-third to one-sixth NSPS levels) are in widespread use on low-sulfur coal plants. These controls have not yet been deployed in the United States, but such systems are now being demonstrated at U.S. plants as part of DOE's CCT program, and several are offered commercially. Post combustion $\mathrm{NO}_{\mathrm{x}}$ controls that employ selective catalytic reduction have been

\footnotetext{
${ }^{11}$ Photochemical ozone is formed from emissions of volatile organic compounds (VOCs) and nitrogen oxides $\left(\mathrm{NO}_{x}\right)$ via a complex series of chemical reactions fueled by sunlight. While the emphasis in the past has been control of VOCs, improved understanding of photochemical smog formation now indicates that $\mathrm{NO}_{\mathrm{x}}$ controls must be a more significant component of ozone reduction strategies (NRC, 1992a).
} 
installed on several gas-fired power plants, including combustion turbines, to meet state and local air quality requirements. Over the next 10 years, new requirements for $\mathrm{NO}_{x}$ reductions at existing and new coal-based power plants are likely to achieve national ambient air quality standards for tropospheric ozone. Also possible are new standards for fine particulates. Future $\mathrm{NO}_{\mathrm{x}}$ controls would likely exceed the modest reductions (10 percent of 1980 levels) already required for acid deposition control.

Title III of the 1990 CAAAs lists 189 substances as "air toxics," subject to maximumachievable control technology when emitted at rates of 10 to 25 tons per year from designated industrial and other sources. Emissions of these hazardous air pollutants from fossil-fueled power plants were exempted from the CAAAs provisions pending further study by the U.S. Environmental Protection Agency (EPA). Air toxics of primary concern to utilities are the 10 to 20 trace substances commonly found in coal, including arsenic, mercury, selenium, nickel, cadmium, and other heavy metals. The basis for regulating emissions of these species from electric utilities would be an EPA finding of an unacceptable health risk or an ecological risk to one or more regions of the country named in the 1990 CAAAs (Zeugin, 1992). Independent of EPA action, however, individual states may impose regulations or guidelines on emissions of hazardous air pollutants.

Current worldwide concern over potential global warming may pose the greatest longterm threat to expanded coal use, primarily because of the emissions of the "greenhouse gas" carbon dioxide $\left(\mathrm{CO}_{2}\right)$ from coal combustion. Over the mid to long term, $\mathrm{CO}_{2}$ emission reductions may be critical to address these concerns, although policy measures could force such reductions sooner. At the present time there is significant scientific uncertainty regarding timing, magnitude, and consequences of increased greenhouse gas emissions. Inevitably, such uncertainty is reflected in varying views about the need for $\mathrm{CO}_{2}$ emissions controls. However, the preponderance of scientific opinion-as reflected, for example, by a recent NRC study (NRC, 1992b)-suggests that the threats are of sufficient concern to warrant some initial actions. Together with some 150 other nations, the United States is already committed to a program of $\mathrm{CO}_{2}$ reduction by virtue of being a signatory to international agreements stemming from the 1992 United Nations Conference on the Environment. Such reductions are currently voluntary, although the Clinton administration is aggressively and successfully pursuing utility participation. The EPACT also involves utilities in programs to establish baseline $\mathrm{CO}_{2}$ emissions.

The most cost-effective method of reducing $\mathrm{CO}_{2}$ emissions from power generation and other coal-based systems is to improve the systems' overall efficiency. DOE's strategic objectives for its Advanced Power Systems Program are consistent with this approach (see Chapter 2). Technology exists to remove $\mathrm{CO}_{2}$ from combustion gases and other coal-based gas streams, but the costs of doing so are high (MIT, 1993), and no proven methods yet exist for disposing of the collected $\mathrm{CO}_{2}$. Beyond the 2040 planning horizon considered in the present study, very high temperature nuclear reactors might be used as an energy source in fossil fuel conversion processes, such as steam gasification of coal, to reduce their greenhouse gas emissions (NRC, 1990).

Methane from coal mining is also of concern as a greenhouse gas. It has been estimated that in the United States approximately 3.6 million metric tons of coalbed methane is released 
each year in this process. A large percentage of this total is from underground mining. ${ }^{12}$ About 30 percent of concentrated methane from wells in the coal seam is now collected and used. The ventilation air exhaust, which typically contains less than 1 percent methane, is not generally collected and makes up over 70 percent of the total methane released to the atmosphere from coal mining (CIAB, 1992). Estimates indicate that the greenhouse effect of the methane released from underground coal mining represents up to 8 or 9 percent of the greenhouse effect of the $\mathrm{CO}_{2}$ released in burning the mined coal. ${ }^{13}$ For a 40 percent thermal efficiency power plant, the additional greenhouse effect of methane released from coal mining is equivalent to decreasing the plant's efficiency by up to about 2 percent. Control of coal mine methane emissions, therefore, has less potential for reducing greenhouse gases than achieving higher plant efficiency through the use of advanced technology. However, methane emissions from coal mining are independent of coal use in combustion equipment; current understanding of global warming issues suggests that they are of sufficient magnitude to justify development of appropriate technology for their control.

Emissions of nitrous oxide $\left(\mathrm{N}_{2} \mathrm{O}\right)$, another greenhouse gas, also arise from coal combustion. Because $\mathrm{N}_{2} \mathrm{O}$ is formed primarily at relatively low temperature and pressure, the largest emissions rates are associated with atmospheric fluidized-bed combustion systems. Overall, $\mathrm{N}_{2} \mathrm{O}$ emissions from coal combustion worldwide are estimated to contribute less than 1 percent of total global warming emissions. The primary sources of $\mathrm{N}_{2} \mathrm{O}$ worldwide are fertilizers and agricultural wastes (NRC, 1992b).

Coal-fired electric power plants and fuel conversion processes are subject to state and federal regulations to protect the quality of surface waters, ground water, and drinking water. The principal environmental concerns are thermal discharges to waterways (discharges prohibited for new plants) and various chemical emissions, including heavy metals, organics, suspended solids, and other aqueous constituents found in power plant waste streams. In recent years there has been increasing attention to control of hazardous or toxic trace chemical species and a general tightening of effluent emission standards at existing and new facilities (Rubin, 1989). High-volume wastes, such as flyash from coal-fired power plants, have been declared "nonhazardous," with only some low-volume wastes such as boiler cleaning sludges falling under the "hazardous" category. The latter require more rigorous treatment and involve much higher disposal costs to avoid surface or ground water contamination. Nonetheless, to control the release of suspended solids and other chemical constituents of high- and low-volume wastes,

\footnotetext{
${ }^{12}$ Methane from U.S. underground mining comes from mine ventilation air (2.29 million metric tons/year), coal seam degasification (1.00 million metric tons/year), and postmining emissions ( 0.24 million metric tons/year).

13 In 1992, 384 million metric tons of coal were produced by underground mining in the United States, with a net release of 3.22 million metric tons of methane. Combustion of the same coal liberated approximately 800 million metric tons of $\mathrm{CO}_{2}$. On a weight basis, the direct and indirect effects of methane have been estimated to be 21 times more powerful than $\mathrm{CO}_{2}$ as a greenhouse gas (NRC, 1992b). The greenhouse effect of the methane released from mining compared to the effect of $\mathrm{CO}_{2}$ from combustion is therefore $21 \times 3.22 \times 100 / 800=8.5 \%$.

More recent studies by the Intergovernmental Panel on Climate Change no longer quantify the indirect effects of methane; rather, only the direct effects are included in the Global Warming Potential. This gives an index of 11 rather than 21 for a 100 -year averaging time.
} 
water treatment systems similar to those found in other industrial processes are an integral requirement for modern power plants.

The large volumes of solid waste that must be disposed of, particularly ash from coal, represent a growing problem because of concern over contamination of ground water and surface waters and the decreased availability of landfill sites for waste disposal. Ash solubility and its effects on ground water can be greatly reduced by processes that fuse ash, resulting in products that can be used as construction materials, such as gravel substitutes. While research on the conversion of solid wastes to higher-value products has shown that by-product and reuse options are technically feasible, such conversion methods currently are not able to absorb the large quantities of material produced and often are not economical in today's markets. Another disposal option, especially applicable to western open-face mines where coal is transported by rail, is returning waste to the coal mine.

To an increasing extent, federal NSPS levels for power plants no longer set the benchmark for environmental control performance. Rather, state and local determinations of "lowest-achievable emission rates" now set the critical requirements in many cases. A related trend is the adoption by some state public utility commissions of "externality adders," economic costs added to the nominal cost of power generation that reflect the environmental damages due to emissions that escape control. Increasingly, state public utility commissions are requiring externality costs to be included in comparing different investment options and associated environmental impacts and risks. The effect is to put further downward pressure on all emissions from coal-based power systems.

\section{SUMMARY}

The principal findings from the preceding review, summarized here, form the basis for the strategic planning scenarios developed by the committee and presented in Chapter 4 .

Coal supplies are expected to be abundant for the periods considered in this study. The steady decline in domestic coal prices over the past 10 years is a trend expected to continue in the near term. In the mid to long term (2006 through 2040), coal production costs are expected to be stable. Given the continuing availability of low-cost domestic coal, and the evolutionary rather than revolutionary nature of changes in energy consumption patterns in the United States, coal will likely continue to satisfy a significant part of growing U.S. energy demands over the next several decades.

Electricity demand is projected to grow through 2010 as the U.S. economy grows. Estimates of new capacity requirements over the next 15 years differ widely, but there appear to be significant markets for retrofit and repowering options, as well as for new capacity construction. Changes in regulatory structure and practice in the electric utility industry since 1979 have contributed to a trend toward more widely distributed, smaller-scale power generation facilities that have relatively low risk and low capital costs. In addition, increased competition is reducing the willingness of the utility industry to develop and deploy advanced power generation technologies that are perceived as having higher risk.

In the near term, natural gas-fired systems will likely be the primary source of new capacity additions, driven by demands for peak and intermediate power, low gas prices, and low 
capital costs relative to coal. However, coal is expected to remain the largest single energy source for power generation, and resource limitations for domestic natural gas, combined with a substantial need for new baseload generating capacity between 2006 and 2040, are anticipated to result in a resurgence of coal-based power generation facilities in the mid-term period. In the longer term, growth of nuclear energy using advanced reactor designs is possible, and such energy could begin displacing coal after 2020. Renewable energy sources are expected to play a growing role in U.S. electric power generation, but they are not anticipated to become a large source of bulk electricity within the periods covered by this study.

Environmental concerns will probably be the most significant influence on future coal use in the United States, and requirements to reduce the environmental and health risks of waste streams from coal technology are expected to grow more stringent. In the near- to mid-term periods, control of $\mathrm{SO}_{2}, \mathrm{NO}_{x}$, and fine particulate air pollutants, solid wastes, and possibly air toxics, will continue to determine the acceptability of coal-based systems, with state and local environmental requirements posing the most restrictive demands on power plant emissions. However, concern over global warming could present the greatest long-term threat to coal use because of the $\mathrm{CO}_{2}$ emissions from coal combustion. Reducing $\mathrm{CO}_{2}$ emissions over the mid- to long-term periods may be critical to maintaining coal's viability as an energy source. The most cost-effective method of reducing $\mathrm{CO}_{2}$ emissions from power generation and other coal-based systems is to improve their overall efficiency.

Expansion of coal-based power generation is anticipated in the developing nations, notably China, and major international markets exist for coal utilization technologies. In the near term, capital investment requirements are expected to be a controlling consideration in most foreign markets. Foreign requirements to minimize conventional pollutant and greenhouse gas emissions will lag those imposed in the United States, but their introduction is expected to have a large impact on international sales of coal-based technologies, especially in the mid- to longterm periods.

World petroleum resources are sufficiently large, and production costs sufficiently low, that prices for imported oil will continue to be governed primarily by political and institutional factors. Oil prices are expected to increase over time. However, international political events and disruptions could produce high price volatility in any time period. When time-averaged imported oil prices exceed $\$ 25$ to $\$ 30 / \mathrm{bbl}$, use of heavy oil and tar from North and South America becomes competitive with conventional petroleum. If production of gaseous and liquid fuels from coal can compete in this price range, a major market for coal beyond power generation could develop. Coal-derived gaseous and liquid fuels could also be used in chemicals production.

\section{REFERENCES}

Carter, M.D., and N.K. Gardner. 1993. Coal Availability Studies: A Federal and State Cooperative Project. Reston, Virginia: U.S. Geological Survey. 
CIAB. 1992. Global Methane Emissions from the Coal Industry. Coal Industry Advisory Board, Global Climate Committee, International Energy Agency. Paris: Organization for Economic Cooperation and Development.

Coal and Synfuels Technology. 1993. Chinese cities get funds gasification. Coal and Synfuels Technology 14(47): 47.

Coal Week International. 1993. World steam coal prices. Coal Week International 14(51): 4-5.

Coal Week International. 1994. Current steam coal prices. Coal Week International 15(32): 4.

DOE. 1993a. Market Potential for Clean Coal Technology Exports: Update Estimates. Working paper submitted to the Office of Fossil Energy, U.S. Department of Energy by Resource Dynamics Corp. under contract DE-AC01-92FE62489.

DOE. 1993b. Foreign Markets for U.S. Clean Coal Technologies, working draft, Dec. 21. Report to the U.S. Congress by the U.S. Department of Energy, Washington, D.C.

Doyle, G. 1987. China's Potential in International Coal Trade. London: International Energy Agency.

EIA. 1992. Coal Production 1992. Energy Information Administration, U.S. Department of Energy. Washington, D.C.: DOE.

EIA. 1994a. Annual Energy Outlook 1994. Energy Information Administration, U.S. Department of Energy, DOE/EIA-0383(94). Washington, D.C.: DOE.

EIA. 1994b. Supplement to the Annual Energy Outlook 1994. Energy Information Administration, U.S. Department of Energy, DOE/EIA-0554(94). Washington, D.C.: DOE.

Energy Daily. 1994. The impact of coal in the U.S. economy cited in study unearths coal's economic benefits. 22(108): 4 .

GRI. 1994. Baseline Projection of U.S. Energy Supply and Demand, 1994 Edition. Chicago: Gas Research Institute.

Harunuzzaman, M., T.P. Lyon, E.H. Jennings, K. Rose, G. Iyyuni, M. Eifert, and T. Viezer. 1994. Regulatory Practices and Innovative Generation Technologies: Problems and New Rate-Making Approaches. NRRI 94-05. Columbus, Ohio: National Regulatory Research Institute.

IEA. 1993a. Coal Information 1992. International Energy Agency. Paris: Organization for Economic Cooperation and Development. 
IEA. 1993b. Annual Report 1992-1993: International Energy Agency. Paris: Organization for Economic Cooperation and Development.

Makovich, L., and G. Smalley. 1993. The electric power industry forecast 1993-2010. Electrical World. 207(11): 17-21, 24.

MIT. 1993. A Research Needs Assessment for the Capture, Utilization and Disposal of Carbon Dioxide from Fossil Fuel-Fired Power Plants. Report for the U.S. Department of Energy under grant no. DE-FG02-92ER30194. Cambridge: Energy Laboratory, Massachusetts Institute of Technology.

NCA. 1993a. Coal Data 1993 Edition. Washington, D.C.: National Coal Association.

NCA. 1993b. Facts About Coal, 1993. Washington, D.C.: National Coal Association.

NRC. 1990. Fuels to Drive Our Future. Energy Engineering Board, National Research Council. Washington, D.C.: National Academy Press.

NRC. 1992a. Rethinking the Ozone Problem. Board on Environmental Studies and Toxicology and the Board on Atmospheric Sciences and Climate, National Research Council. Washington, D.C.: National Academy Press.

NRC. 1992b. Policy Implications of Greenhouse Warming. Committee on Science, Engineering, and Public Policy, National Research Council. Washington, D.C.: National Academy Press.

NRC. 1993. Advanced Exploratory Research Directions for Extraction and Processing of Oil and Gas. Board on Chemical Sciences and Technology, National Research Council. Washington, D.C.: National Academy Press.

Potential Gas Committee. 1993. Potential Supply of Natural Gas in the United States. Golden, Colorado: Potential Gas Agency, Colorado School of Mines.

Preston, G.T. 1994. Testimony to the U.S. Senate Committee on Energy and Natural Resources, March 8.

Riva, J.P., Jr. 1991. Dominant Middle East oil reserves critically important to world supply. Oil and Gas Journal 89(38): 62-68.

Rohrbacher, T.J., D.D. Teeters, L.M. Osmonson, and M.N. Plis. 1993. USBM Coal Recoverability Program: 1993 Review of Results, Draft. Denver, Colorado: U.S. Department of the Interior, Bureau of Mines. 
Rubin, E.S. 1989. The implications of future environmental regulations on coal-based electric power. Annual Review of Energy. Vol. 14. Palo Alto, California: Annual Reviews.

The Alliance to Save Energy, American Gas Association, and Solar Energy Industries Association. 1992. An Alternative Energy Future. Washington, D.C.: The Alliance to Save Energy.

Zeugin, L.E. 1992. Managing Hazardous Air Pollutants: Implications of the 1990 Clean Air Act Amendments for Coal Combustion. Proceedings of the Ninth Annual International Pittsburgh Coal Conference, October 1992, Pittsburgh, Pennsylvania. Pittsburgh: University of Pittsburgh. 


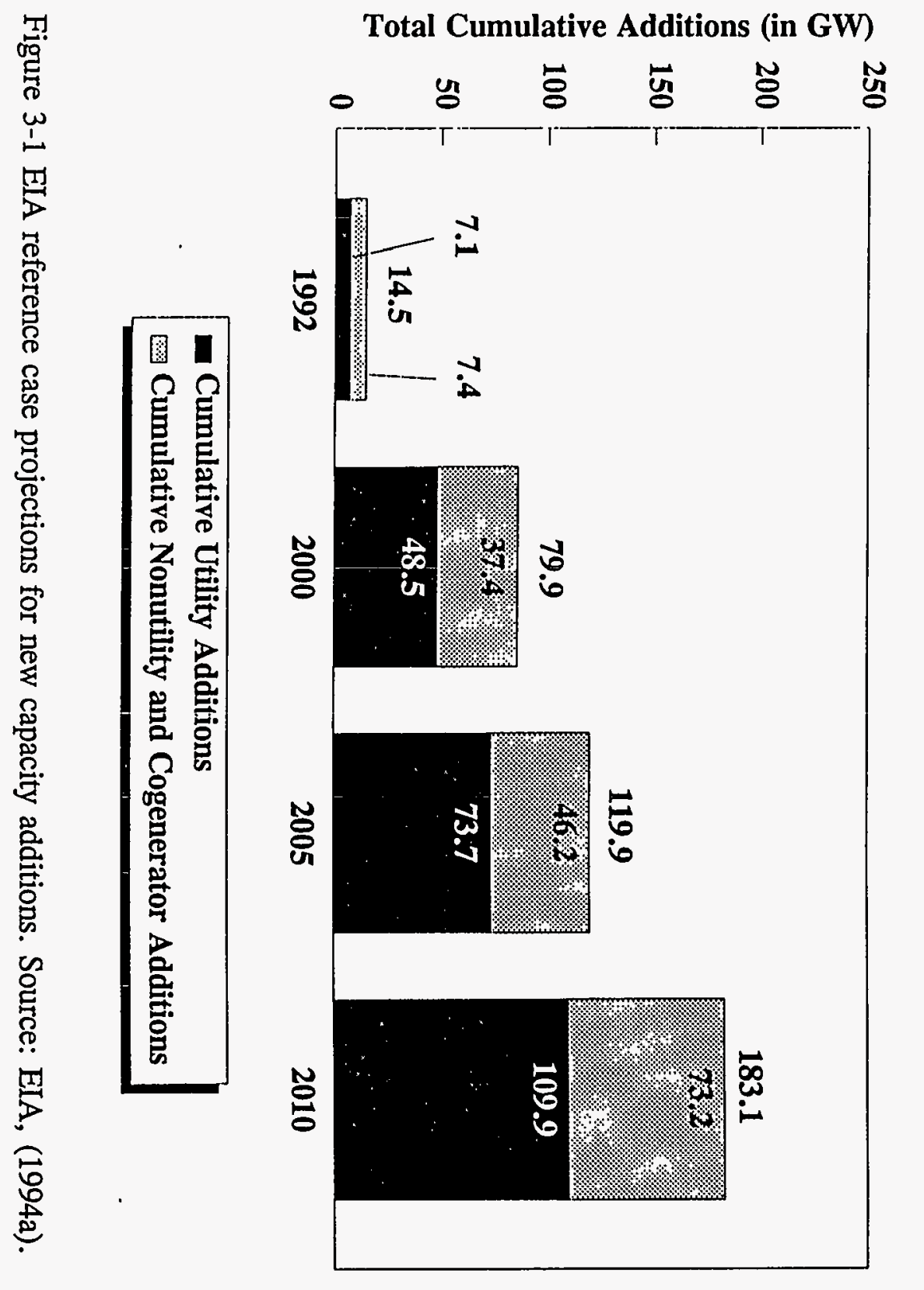



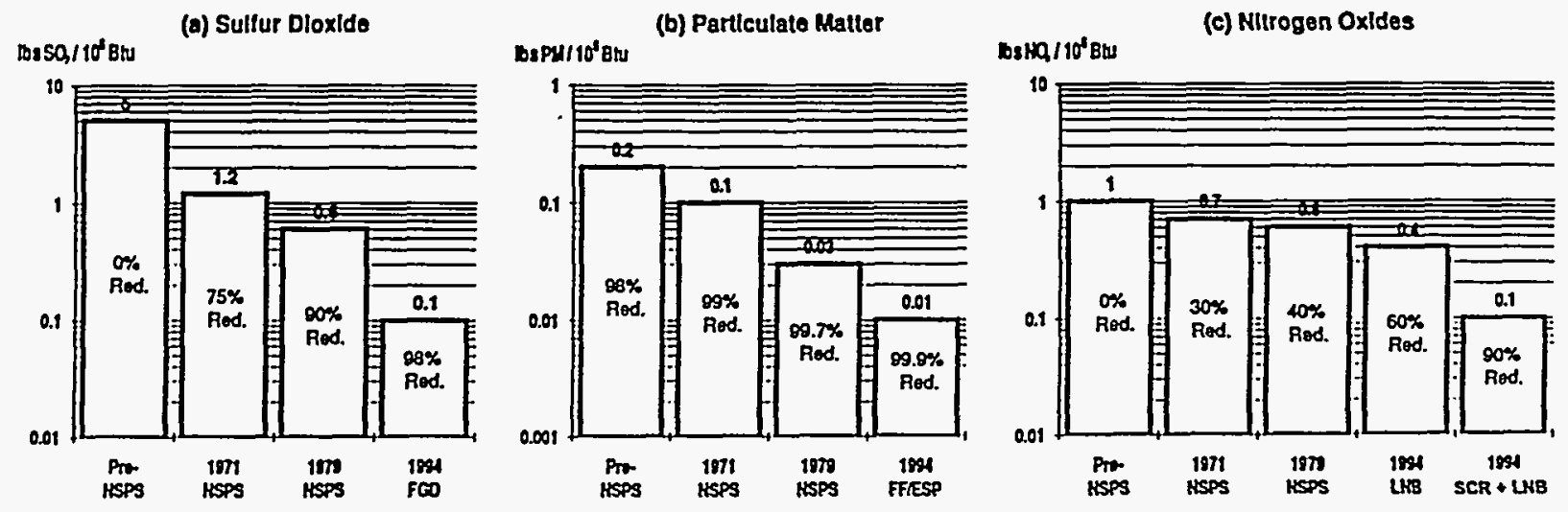

Figure 3-2 Trend in emission rates of criteria air pollutants from a new pulverized coal power plant.

Percentage reductions are relative to an uncontrolled power plant based on a dry-bottom tangentially fired boiler firing bituminous coal of $10,000 \mathrm{Btu} / \mathrm{lb}$ heating value and containing 2.5 percent sulfur, 12 percent ash, and 10,000 Btu/lb. Percentages on the bars are percent reductions relative to uncontrolled emissions of that component.

NSPS $=$ New Source Performance Standards.

FGD = flue gas desulfurization (wet magnesium-enhanced lime).

$\mathrm{FF}=$ fabric filter (baghouse).

ESP $=$ electrostatic precipitator.

$\mathrm{LNB}=$ low $\mathrm{NO}_{\mathrm{x}}$ burner.

$\mathrm{SCR}=$ selective catalytic reduction. 
Table 3-1 Annual Growth in Gross Domestic Product and Electricity Demand by Decade, 1960-2010 (percent) ${ }^{\mathrm{a}}$

\begin{tabular}{lcc}
\hline Period & Gross Domestic Product Growth & Electricity Demand Growth \\
\hline $1960-1970$ & 3.8 & 7.3 \\
$1970-1980$ & 2.8 & 4.2 \\
$1980-1990$ & 2.6 & 2.6 \\
$1990-2010$ & $1.8-2.4$ & $1.0-1.5$ \\
\hline
\end{tabular}

aItalics indicate projected values.

Source: EIA (1994a). 
Table 3-2 Various Projections of Total U.S. Generating Capacity, 2000 and 2010 (GW)

\begin{tabular}{cccccccc}
\hline Year & EIA $^{\mathrm{a}}$ & WEFA & GRI & DRI & NERC & EEI & NERA \\
\hline 2000 & 784 & 747 & 788 & 792 & 719 & 813 & 789 \\
2010 & 857 & 878 & 861 & 879 & NA & 925 & NA \\
\hline
\end{tabular}

NOTES:

EIA data correspond to reference case and include cogeneration capacity.

WEFA (Wharton Economic Forecasting Association, The WEFA Group) projections include cogeneration capacity. GRI (Gas Research Institute) projection represents nameplate capacity, which is typically 5 to 10 percent higher than net summer capacity.

DRI (DRI/McGraw-Hill) projection includes cogeneration and represents nameplate capacity. NERC, North American Electric Reliability Council.

EEI (Edison Electric Institute) projection includes cogeneration.

NERA, National Economic Research Association.

NA, not available.

Source: EIA (1994a). 
Table 3-3 Various Coal Consumption Forecasts, 2000 and 2010 (in millions of tons)

\begin{tabular}{lrrrr}
\hline Year/Forecast & EIA AEO94 & DRI & GRI & WEFA \\
\hline 2000 & & & & \\
Production & 1,081 & 1,090 & 1,091 & 1,060 \\
Consumption & 958 & 961 & 973 & 958 \\
Power generation & 837 & 844 & 863 & 847 \\
2010 & & & & \\
Production & 1,223 & 1,379 & 1,333 & 1,278 \\
Consumption & 1,079 & 1,237 & 1,182 & 1,165 \\
Power generation & 950 & 1,004 & 1.077 & 1,053 \\
\hline
\end{tabular}

NOTES:

EIA AEO94, Energy Information Administration, Annual Energy Outlook, 1994. DRI, Data Resources, Inc./McGraw Hill.

GRI, Gas Research Institute.

WEFA, Wharton Economic Forecasting Association, The WEFA Group.

Source: EIA (1994a). 
Table 3-4 National Petroleum Council Estimate of Remaining Recoverable Domestic Natural $\mathrm{Gas}^{\mathrm{a}, \mathrm{b}}$

\begin{tabular}{|c|c|c|c|}
\hline $\begin{array}{l}\text { Wellhead Price } \\
\text { (1992 } \\
\text { dollars } / 10^{6} \text { Btu) }\end{array}$ & $\begin{array}{c}\text { Current Technology } \\
\text { (Tcf) }\end{array}$ & $\begin{array}{l}\text { Advanced } \\
\text { Technology }^{\mathrm{d}} \\
\text { (Tcf) }\end{array}$ & $\begin{array}{c}\text { Resource/1992 } \\
\text { Consumption (Years) }\end{array}$ \\
\hline Unspecified & 1,065 & 1,295 & 72 \\
\hline$\$ 3.74$ & 600 & 825 & 46 \\
\hline$\$ 2.67$ & 400 & 600 & 33 \\
\hline
\end{tabular}

${ }^{a}$ These amounts include production in Alaska, which, at higher prices, might be delivered to the lower 48 states and which, for the unspecified price and advanced technology case, was estimated to be 13 percent of the total resource.

'Total U.S. natural gas production up to 1990 was approximately 700 Tcf.

'The EIA projects a wellhead price rise to $\$ 3.50 /$ million Btu by 2010 (EIA, 1994a). The price to a utility is greater than the wellhead price and may vary by region. In 1992 the average wellhead price was $\$ 1.75 /$ thousand cubic feet (Mcf), whereas the delivered price to electric utilities was $\$ 2.36 / \mathrm{Mcf}$ (EIA, 1994a).

Improvements in imaging of underground structure, in fracturing to improve production rate, and in other production-related technologies that are believed to be reasonable extrapolations of the current state of the art.

'U.S. consumption in 1992 was 18 Tcf.

Source: Potential Gas Committee (1993). 
Table 3-5 U.S. Natural Gas Supply and Disposition, 1992-2010 (quads)

\begin{tabular}{lccccc}
\hline Category/Source & 1992 & 2000 & 2005 & 2010 & $\begin{array}{c}\text { Annual Growth } \\
\text { (percent) }\end{array}$ \\
\hline $\begin{array}{l}\text { Production } \\
\text { EIA }\end{array}$ & 18.51 & 19.63 & 20.87 & 20.89 & 0.7 \\
$\quad$ GRI & 18.10 & 20.00 & 21.20 & 22.40 & 1.2 \\
Net Imports & & & & & \\
EIA & 2.49 & 2.95 & 3.32 & 3.86 & 2.5 \\
GRI & 2.10 & 3.10 & 3.70 & 3.80 & 3.3 \\
Total Supply & & & & & \\
EIA & 21.00 & 22.58 & 24.19 & 24.75 & 0.9 \\
GRI & 20.20 & 23.20 & 24.90 & 26.20 & 1.5 \\
Total Consumption & & & & & 1.2 \\
EIA & 20.15 & 22.67 & 24.31 & 24.89 & 1.4 \\
GRI & 20.30 & 23.10 & NA & 26.10 & \\
Power Generation & & & & & 3.3 \\
EIA & 2.86 & 4.36 & 5.24 & 5.10 & 2.3 \\
GRI & 2.88 & 3.91 & NA & 4.32 & \\
\hline
\end{tabular}

NA, not available.

Sources: EIA (1994a), GRI (1994). 
Table 3-6 Projected Natural Gas Prices for Electric Utilities (dollars/million Btu)

\begin{tabular}{lllllc}
\hline Source & 1992 & 2000 & 2005 & 2010 & Annual Growth (\%) \\
\hline EIA & 2.28 & 3.03 & 3.88 & 4.43 & 3.8 \\
GRI & 2.47 & 3.15 & NA & 3.78 & 2.4 \\
\hline
\end{tabular}

NA, not available.

Sources: EIA (1994a), GRI (1994).

Table 3-7 Comparative Costs of Electricity from Wind, Photovoltaic, and Biomass Sources (cents/kWh)

\begin{tabular}{lccc}
\hline Source & 1990 & 2000 & 2010 \\
\hline Wind & $8-10$ & 4 & $3-4$ \\
Photovoltaic & $37-53$ & $11-32$ & $9-16$ \\
Biomass & $5-9$ & $5-6$ & 1 \\
\hline
\end{tabular}

Source: Preston (1994). 
Table 3-8 World and U.S. Petroleum Resources

\begin{tabular}{lccc}
\hline Source & $\begin{array}{c}1992 \text { Resource } \\
\text { Consumption (billion } \\
\text { bbl) }\end{array}$ & $\begin{array}{c}\text { Total Resource } \\
\text { (billion bbl) }\end{array}$ & $\begin{array}{c}\text { Resource/ } \\
1992 \text { Consumption } \\
\text { (years) }\end{array}$ \\
\hline World & 20.4 & $1,700^{\mathrm{c}}$ & 83 \\
$\begin{array}{l}\text { United States } \\
\text { (domestic) }\end{array}$ & 3.1 & $99-204^{\mathrm{d}}$ & $32-66$ \\
\hline
\end{tabular}

Data from EIA (1994a).

'Total U.S. petroleum consumption in 1992 was 6.2 billion bbl, with about 50 percent accounted for by oil imports (EIA, 1994a). If total consumption were used for the last column, the resource/consumption value for the United States would decrease to 16-33 years.

'See Riva (1991).

dow number based on current technology and price of $\$ 20 / \mathrm{bbl}$; high number based on advanced technology and price of $\$ 27 / \mathrm{bbl}$ (NRC, 1993). 
Table 3-9 Projections for Domestic Coal Consumption by End Use, 1990-2010 (million short tons) ${ }^{\mathrm{a}}$

\begin{tabular}{lrrrrr}
\hline End Use & 1990 & 1992 & 2000 & 2005 & 2010 \\
\hline Residential and commercial & 7 & 6 & 6 & 6 & 5 \\
Industrial & 76 & 74 & 87 & 94 & 101 \\
Coke plants & 39 & 32 & 28 & 24 & 21 \\
Electricity generation & 774 & 780 & 837 & 862 & 950 \\
\hline
\end{tabular}

aData for 1990 and 1992 are actual rather than projected values.

Source: EIA (1994a). 


\section{The Strategic Planning Framework}

This chapter outlines the methods and strategic planning framework used to assess DOE's coal program, in keeping with the committee's charge. To establish an analytic framework, the committee defined optimal planning horizons; national coal technology requirements corresponding to those horizons, under the most probable and alternative scenarios; and, finally, criteria that might be used to set DOE coal program priorities in view of these considerations, DOE's mission, and the requirements of EPACT.

As seen in Chapter 2, DOE's coal program planning has generally focused on planning horizons only to 2010, with the objective of developing technologies that will be deployed and yield benefits in subsequent years (Randolph, 1992). However, as the discussions in Chapter 3 indicated, coal will undoubtedly be a major source of energy well past the year 2010, with production of coal-derived liquid and gaseous fuels becoming a major potential consumer of coal after 2020. The committee thus concluded that a longer planning horizon is needed to develop a national $\mathrm{RDD} \& \mathrm{C}$ program relevant to this broadening spectrum of expected coal uses.

Three planning periods were identified to assess the DOE coal program: near-term, 1995-2005; mid-term, 2006-2020; and long-term, 2021-2040. The committee developed scenarios for each of these three planning periods, reflecting likely U.S. energy demands, resource and environmental constraints, and likely coal use outside the United States.

\section{BASELINE STRATEGIC PLANNING SCENARIOS}

The committee's baseline strategic planning scenarios, reviewed in Table 4-1, describe demanding, but not unreasonable, circumstances against which the requirements for coal RDD\&C can be assessed. It will be seen that these scenarios are based on the major findings of Chapter 3 and encompass a range of requirements envisioned by the committee as likely to arise. While circumstances less demanding can be envisioned, it is the belief of the committee that a major role of DOE is to provide technological insurance for a credibly demanding future. For example, in the view of the committee, requirements to reduce $\mathrm{CO}_{2}$ emissions are sufficiently probable to provide a strong driving force for the very ambitious DOE efficiency goals for power generation (see Chapter 2). Further, the coal program should be sufficiently robust and flexible to accommodate evolving needs. After the baseline scenarios are presented, alternative scenarios that are more and less demanding are also reviewed. 


\section{ALTERNATIVE SCENARIOS}

Given the inherent uncertainty of predictions, the committee developed and considered several variations on the baseline scenarios. Less demanding scenarios would postpone the need for advanced coal utilization technology, while more demanding scenarios would accelerate the need.

\section{Near Term}

Less demanding scenarios would result if natural gas and oil prices remained low or if concerns about the environment diminished. If no natural gas shortages were anticipated, for example, there would be less need for new or improved technologies for coal-based power generation. If oil supplies remained plentiful and prices low, there would be little incentive to develop technologies to produce liquid fuels from coal. Less severe environmental constraints would also reduce the need to develop clean coal technologies for both domestic and international markets. In particular, if no new regulations were enacted to control air toxics or other air pollutants, and if concerns about $\mathrm{CO}_{2}$ emissions diminished, there would be fewer pressures to develop advanced environmental control technologies or maximally efficient coalbased plants.

On the other hand, the demand for new coal-based plants would be accelerated if there were unexpected shortages of electricity or natural gas. This scenario would create more demanding RDD\&C requirements for advanced coal utilization technologies. Disruptions in the supply of imported oil could increase oil prices significantly, resulting in new emphasis on domestic energy security and coal liquefaction technology. A more demanding short-term scenario could also result from increased domestic or international concern about the environmental impacts of coal-based facilities. Concern about the effects of global warming could lead to penalties for $\mathrm{CO}_{2}$ emissions, encouraging faster development and use of very high efficiency coal-based systems and greater $\mathrm{R} \& \mathrm{D}$ on $\mathrm{CO}_{2}$ removal and disposal options.

\section{Mid and Long Term}

Over the mid and long term, less demanding scenarios would result from the continued availability of domestic natural gas or gas imports (including liquefied natural gas) or a decrease in electricity demand growth. In these cases there would be less demand for new coal-based generating capacity. Imported oil and bitumen prices below $\$ 30 / \mathrm{bbl}$ would reduce incentives to manufacture liquid fuels from coal. However, interim technology advances (e.g., in coproduct systems) might allow coal-derived fuels to be produced competitively at an equivalent crude oil price of $\$ 25 / \mathrm{bbl}$ or less. If, contrary to expectations, environmental constraints on coal use for power generation do not become more severe over the mid to long term, there will be less need for associated clean coal technologies, such as advanced environmental controls and highefficiency systems. 
More demanding mid- to long-term scenarios, on the other hand, could result from unexpectedly high growth in electricity demand, such that new coal-based capacity would be needed earlier than expected. High natural gas prices could also accelerate the need for such new capacity and perhaps also encourage a new synthetic natural gas industry. Disruptions in international oil and tar markets and related price increases could boost the demand for coal liquefaction. Increased coal RDD\&C might also be needed if there is earlier or more widespread enactment of new environmental restrictions on power plant solid wastes, air emissions, or liquid discharges. Finally, heightened concern over global warming could push the drive for highefficiency technology, $\mathrm{CO}_{2}$ sequestration methods, and the use of nuclear energy to reduce greenhouse gas emissions.

\section{SCENARIO IMPLICATIONS FOR RDD\&C PLANNING}

The committee's baseline planning scenarios suggest that DOE's coal program should anticipate national needs in several areas:

- Growing U.S. markets for advanced coal-based generating technologies, probably beginning about a decade from now and with sustained longer-term demand for these technologies.

- More effective and less costly environmental control systems to meet the increasingly stringent demands of federal, state, and local regulatory agencies for both new and existing power plants.

- High-efficiency power generation systems to address growing concerns about greenhouse gas emissions, resource depletion, and other environmental impacts.

- Reliable, smaller-scale technologies, compatible with the emerging trends to more decentralized power generation and more competitive business accompanying utility deregulation.

- Future domestic markets for coal-derived fuels likely emerging in the mid to long term.

- Growing international markets for low-cost environmental control technologies and coal-based electric power systems, for both retrofit and new plant applications.

The alternative scenarios suggest that the timing of projected changes may vary but that the principal requirements will remain much the same. Regardless of timing, then, there is likely to be a demand for low-cost, clean, efficient, coal-based power generation technologies and for high-efficiency gasification for power generation and production of clean gaseous and liquid fuels. However, shifts in the timing of requirements, such as those described under the alternative scenarios above, would necessitate changes in DOE's coal program priorities. 


\section{ADDITIONAL CRITERIA TO SET NATIONAL COAL RDD\&C PRIORITIES}

While the scenarios above provide valuable information to establish overall goals for the DOE coal program, further criteria are needed to set more specific program objectives and priorities. The committee's strategic planning framework therefore employed further criteria, consistent with the goals of EPACT and the National Energy Strategy (DOE, 1991). In the most general terms, these goals are to promote national economic well-being through lower energy costs, creation of U.S. jobs, and improved balance of payments based on technology manufacture and export; to protect and enhance environmental quality by minimizing emissions from coal-based facilities, as well as the impacts of these facilities' solid, liquid, and gaseous wastes; and to enhance national security by reducing dependence on foreign energy sources. Following from these general goals (which were also reflected in the scenarios above) and consistent with its charge, the committee developed the following additional criteria to evaluate the strategic importance of individual DOE programs for the three planning periods defined, namely; the near-term (1994-2005); mid-term (2006-2020); and long-term (2021-2040) periods.

\section{General criteria}

- Are the timing and goals of the program consistent with the scenarios and objectives developed by the committee and with other EPACT and DOE goals and objectives?

- What is the potential for technological success?

\section{Economic criteria}

- What potential does the technology have to reduce the costs of electric power, gaseous or liquid fuels, or other by-products for both new facilities and existing plants?

- Does a market exist for the technology and how large is it? What export potential does the technology have?

- What potential does the technology have to increase the international competitiveness of U.S. firms?

- What potential is there to accelerate application of the technology?

\section{Environmental criteria}

- What potential does the technology have to economically control, reduce, or eliminate environmentally important wastes, notably criteria air pollutants $\left(\mathrm{NO}_{x}, \mathrm{SO}_{2}\right.$, fine particulates), air toxics (inorganic and organic), greenhouse gas emissions $\left(\mathrm{CO}_{2}\right.$, methane), solid wastes (hazardous and nonhazardous), and liquid wastes (organic and inorganic) from coal-based facilities for power generation and fuels production? 
- What is the technology's applicability to new and existing plants in both the United States and other countries?

The DOE role

- Is there a role for DOE given the existence of other domestic industrial programs, other U.S. government programs, foreign programs, and the projected market for the technology?

- What is the recommended role for DOE?

The need for DOE participation requires special consideration because both domestic and foreign groups may be actively carrying out related programs. However, the national goal of improving the U.S. economy by creating more U.S. jobs and improving the balance of payments calls for a competitive and well-rounded U.S. program. With proper planning and setting of priorities, DOE programs can have several important roles:

- Accelerating the commercial application of improved technologies through cost sharing and other arrangements;

- Promoting the development and demonstration of new systems;

- Developing a technical basis for improved systems and components, including performing and supporting advanced research aimed at enhanced cost and efficiency; and

- Identifying major opportunities to improve cost and performance through systematic modeling of systems and components.

The relative importance and practical application of the above considerations necessarily depend on the individual program and the subject addressed, as will be seen in subsequent chapters. To prepare for work across all timeframes, DOE activities now need to focus-not only on near-term demonstration and commercialization but also on longer-term $R \& D$ for the mid term and beyond and on basic R\&D for the long term. To best assess DOE's coal program in terms of the above criteria, the committee focused its discussions of coal-based technologies in Part II on several areas: the state of the art of the technology; the technical issues, risks, and opportunities; and the current status of DOE and other programs. Thus, the areas addressed cover not only the technology's current status but also its potential for performance and cost improvements, the likelihood of its successful further development, and the existence of domestic and overseas markets. For each technology or group of technologies examined in Part II, a set of findings summarizes the critical issues to be addressed in any continuing or future DOE program. 


\section{REFERENCES}

DOE. 1991. National Energy Strategy, First Edition 1991/1992. U.S. Department of Energy. Washington, D.C.: DOE.

Randolph, J.G. 1992. The U.S. Government's Strategic Plan for Advanced Coal Technology. Paper presented to the International Committee for Coal Research, September 17. 


\begin{tabular}{lccc} 
& Near-Term, & Mid-Term, & Long-Term, \\
Area & $1994-2005$ & $2006-2020$ & $2021-2040$ \\
\hline
\end{tabular}

\section{Electric power} generation

(domestic)
- Demand for new baseload electric power generation stations will be low.

- Sufficient natural gas will be available to meet limited needs for new capacity.

- Natural gas prices may rise but not enough to justify investment in new coal plants.

- Growing concerns about future natural gas supply and price, and about future environmental restrictions, stimulate planning for cleaner, more efficient, coal-based technologies.

- Growing trend toward smaller, more decentralized power generation systems in response to utility deregulation and increased competition; emphasis on reliable, low-risk technologies.
- Substantial need exists for new generating capacity.

- Concerns about future natural gas supply and price result in new demand for coal-based capacity.

- Economic incentives for efficiency

improvements increase.

- Continued trend toward decentralization and risk aversion for new power generation technologies.
- Due to higher prices for natural gas, advanced coal-based technologies used increasingly.

- Power generation using natural gas and 1970 s and 1980 s nuclear technologies decreases.

- Renewables a significant but not predominant source of electric power. - Construction of advanced nuclear power plants begins during this period, providing new competition for coalbased systems. 
Table 4-1 Baseline Scenarios To Assess Coal RDD\&C Needs (Continued)

\begin{tabular}{llll}
\hline & Near-Term, & Mid-Term, \\
Area & $1994-2005$ & $2006-2020$ & $2021-2040$ \\
\hline
\end{tabular}

\section{Environmental} constraints

$\vec{\omega}$

Foreign Markets (power generation systems)

Synthetic fuels from coal
- Existing Clean Air Act requirements met by modifying existing coal plants using current or near-term control technologies.

- By the end of the period, more stringent regulations on fine particulates, $\mathrm{NO}_{\mathrm{x}}$, and air toxics may be in place. Concerns may be growing about $\mathrm{CO}_{2}$ emissions.

- State and local requirements for facility siting and operation continue to push use of state-of-the-art environmental controls.

- New capacity needs are met by existing technology, but interest grows in more advanced and lower-cost systems for environmental controls.

- Oil and natural gas prices rise but not enough to justify investment in processes to manufacture liquid fuels or synthetic natural gas from coal.
- Air pollution control and solid waste disposal requirements become more severe.

- New $\mathrm{CO}_{2}$ emissions penalties provide new incentives to install high-efficiency, coal-based generating systems and to continue $\mathrm{R} \& \mathrm{D}$ on $\mathrm{CO}_{2}$ removal and disposal options.

- Maximum-efficiency coal-based systems are required to minimize $\mathrm{CO}_{2}$ emissions; attention is given to establishing $\mathrm{CO}_{2}$ removal and disposal options.

- Pressure continues to reduce all emissions to absolute minimum and to reuse or recover solid wastes as byproducts; advanced emissions control systems are required for coal-based plants.

- Markets develop for advanced coalbased power generation systems to provide new capacity.

- International oil prices rise toward the level where products from dedicated coal liquefaction can compete with petroleum products.

- Production of lower-cost, coal-based liquids in conjunction with gasification combined-cycle systems for power generation becomes economic.

- Markets grow for proven highperformance systems, but cost competition is severe.

- High international oil prices lead to major production of liquids from coal. - High natural gas demand and prices lead to pioneer plants for synthetic natural gas production in the latter part of this period. 
PART II

OVERVIEW OF CURRENT DOE COAL PROGRAMS 


\section{Coal Preparation, Coal-Liquid Mixtures, and Coalbed Methane Recovery}

DOE programs addressed in this chapter-namely, coal preparation, coal-liquid mixtures, and coalbed methane recovery-currently constitute relatively minor components of the total DOE coal program. Brief descriptions of the technologies, the state of the art, and current programs are provided. The committee's findings are then presented, with emphasis on the future role of DOE programs vis-à-vis private sector activities, requirements for commercial technologies, links to other major DOE efforts such as power generation, and research opportunities.

\section{COAL PREPARATION}

\section{Description of Technology}

Coal preparation-or cleaning-is the removal of mineral matter from as-mined coal to produce clean coal, a quality-controlled product with a composition that adheres to specifications based primarily on environmental and combustion performance. Its primary purpose is to increase the quality and heating value (Btu/lb) of coal by lowering the level of sulfur and mineral constituents (ash). In most Eastern bituminous coals, roughly half to twothirds of the sulfur occurs in a form that can be liberated by crushing and separated by mechanical processing. Western coals typically contain much lower levels of sulfur, have lower heating values and are not readily amenable to physical cleaning methods for sulfur reduction. All coals contain mineral matter that also can be removed through physical cleaning. Coal preparation as currently practiced in the coal industry involves four generic steps: characterization, liberation, separation, and disposition.

During characterization, the composition of the different-size raw coal particles is identified. The composition of the raw coal and the required clean coal specifications dictate the type of equipment that must be used to remove the mineral matter. Crushing liberates mineral matter. Complete liberation can only be approached by reducing the mined coal to very fine sizes, since particles containing both coal and mineral matter, called middlings, are also produced during crushing. Separation involves partitioning of the individual particles into their appropriate size groupings-coarse, intermediate, and fine fractions-and separating the mineral matter particles from the coal particles within each size fraction. Separation techniques for 
larger-size raw coal particles generally depend on the relative density difference between the organic coal and inorganic mineral matter particles. Separation techniques for fine raw coal particles utilize the difference in the surface properties of the particles in water. Disposition is the dewatering and storage of the cleaned coal and the disposal of the mineral matter.

\section{Development History}

Coal preparation began simply as a means of controlling the size of raw coal, but mechanized mining led to mechanized cleaning and the subsequent evolution of coarse, intermediate, and fine coal cleaning defined in terms of raw coal particle size ranges. All coals for the metallurgical and export markets are beneficiated, as well as coals sold for other industrial purposes. For most of its history, the primary objective of steam coal cleaning has been to reduce ash levels rather than sulfur content. The introduction of environmental requirements in the 1970 s increased the interest in more extensive cleaning of coal to remove larger amounts of sulfur. Today, fine coal (less than $0.5 \mathrm{~mm}$ ) cleaning is being further subdivided. Coal quality specifications have become more restrictive as a result of environmental regulations and as the impact of coal quality on boiler operating problems, such as slagging and deposition on tubes, has become better understood.

Coal preparation technology was first developed for the European coal industry and was licensed as needed by American companies. Mineral processing technology was also adapted for coal preparation. Significant technology development was conducted by the U.S. steel industry, since the coal used as feedstock for coke is required to meet very stringent specifications, particularly for sulfur content. The U.S. Bureau of Mines established internationally recognized in-house expertise in coal cleaning; this effort was continued under the DOE at the Pittsburgh Energy Technology Center (PETC). As a result of the tightening of coal specifications to comply with environmental regulations, EPRI (Electric Power Research Institute) established a Clean Coal Testing Facility (spun off in 1994 as an independent company, CQ, Inc.). In addition, a number of states, including Pennsylvania, West Virginia, Illinois, Ohio, and Kentucky, established research programs to improve the quality of their coals. Some research on coal cleaning has also been conducted by those oil companies involved in coal production.

\section{State of the A.rt}

Coal preparation technologies are widely practiced by the coal industry. Recent R\&D efforts (Feeley et al., 1994; Killmeyer et al., 1994; Hucko et al., 1994) have been aimed at developing processes that will further reduce both the sulfur and ash contents of coals. Coal cleaning techniques for the fine fractions also are now commercial. Many of these same techniques have been utilized to produce the very clean coals required for coal-liquid mixtures (see below). Sustained investigations into chemical and biological coal preparation techniques that remove organic as well as inorganic sulfur have not, however, produced any systems with a strong potential for commercialization, largely because of their high costs. Indeed, from the perspective of many coal users, the higher cost of coals subjected to advanced levels of 
preparation makes them unattractive relative to naturally occurring coals with lower sulfur and ash contents. Furthermore, many of the advanced power and fuel systems are designed to be fuel flexible, so there are limited markets for highly cleaned coals in the power generation sector.

\section{Current Programs}

DOE currently performs or funds the majority of coal preparation R\&D in the United States. This activity falls primarily within the Advanced Clean Fuels Research Program. The FY (fiscal year) 1994 program budget of $\$ 11.3$ million included $\$ 4.6$ million for work on technologies for producing premium fuels and removal of air toxic precursors; $\$ 2.25$ million for continued testing of high-efficiency processes; and $\$ 4.1$ million for continuation of in-house bench-scale and characterization research at PETC related to advanced physical and chemical cleaning concepts (DOE, 1994a). In addition to the direct funding of the coal preparation program, the AR\&TD (advanced research and technology development) component of the DOE budget supports a number of closely allied programs of a more basic nature, such as the $\$ 1.9$ million program on the bioprocessing of coal for sulfur and nitrogen removal, which is part of DOE's Advanced Manufacturing Technology program. This program recently shifted its emphasis to the removal of $\mathrm{SO}_{x}$ and $\mathrm{NO}_{\mathrm{x}}$ from combustion gases, rather than from coal.

For FY 1995, DOE has proposed a 52 percent reduction in funding for coal preparation, to a total of $\$ 5.5$ million. The main thrusts of the program include continued research on advanced physical coal cleaning methods to produce premium coal fuels very low in ash, sulfur and air toxic precursors at the proof-of-concept scale of technology development ( $\$ 2.6$ million), and continued in-house research on bench-scale development of advanced cleaning concepts ( $\$ 2.0$ million) and related studies ( $\$ 0.8$ million). The AR\&TD program on bioprocessing of coal would continue at its present level ( $\$ 1.9$ million), with emphasis on involvement with small and emerging companies.

\section{Technical Issues, Risks, and Opportunities}

Current physical coal cleaning techniques cannot reduce the sulfur content of coal to the levels needed to comply with most environmental regulations. Although the inorganic sulfur component of coal can be removed with other mineral matter, the organic sulfur is chemically bonded to the coal and is not amenable to physical separation. Biological and chemical methods for sulfur removal so far have not been promising for commercial-scale application. Because coal is an abundant and relatively low cost fuel, the added cost of advanced preparation technology, combined with the cost of coal that is lost with separation process wastes, makes it extremely difficult for advanced cleaning methods to be economically competitive for applications involving direct coal use. The most promising applications for advanced beneficiation methods lie in the production of premium fuels that replace oil or gas (e.g., coalliquid mixtures, discussed below). However, current and projected prices for oil and gas make it unlikely that significant markets for coal-based alternative fuels will emerge before the midterm period. In the near term, however, coal preparation might prove a desirable technique for 
selective treatment of coal to meet possible future hazardous air pollutant regulations by reducing trace element concentrations prior to combustion.

The utility industry is interested in promoting technical and economic improvements in coal beneficiation methods as an indirect means of reducing fuel-related costs. Lower-sulfur fuels provide better cost-benefit solutions for older boilers than scrubbers. Burning upgraded coal reduces the cost of maintaining boiler systems and increases combustion efficiency. $\mathrm{SO}_{\bar{x}}$ reduction in the flue gas reduces scrubber costs where flue gas desulfurization (FGD) is needed. Achieving maximum energy recovery requires improved liberation, improved separation efficiency, total cleaning, and process control. Size reduction and thermal drying account for about 75 percent of the capital costs and 50 percent of the operating costs for processing coal. The challenge for coal cleaning is to deliver coal at a price that is economically competitive with other sources of coal of comparable quality. Thus, the markets for cleaned coals are highly dependent on site-specific factors.

There is an emerging global market for this segment of the U.S. coal industry, particularly in India, Poland, and China, which have large reserves of relatively low quality coal. Improved U.S. coal preparation technology would make the United States more competitive in the international coal technology market. Improving the technology, in some cases, requires more development. For example, commercial preparation is not currently economically optimized. There is a need for testing and verifying new technologies, performing unit operations analysis, developing instrumentation for process control, including computerized online analyzers, and improving dewatering for both fine high-rank coals as well as low rank coals. However, the R\&D and demonstration planning should use market-based decision tools and have extensive industrial participation.

\section{Findings}

DOE has contributed to the development of the fine coal cleaning technology that is now commercially available. Applied research to improve current commercial preparation processes may help such technology compete more effectively, especially in international markets. Advanced power and fuel systems are being designed for fuel flexibility and high-efficiency sulfur removal and may be unlikely to require coals that have been subjected to coal preparation beyond current commercial practice.

Reduction of trace element concentrations in coal representing air toxic precursors may offer an R\&D opportunity for meeting future, as yet undefined, hazardous air pollutant emission standards. Work in this area is addressed in the DOE's proposed program for FY 1995. 


\section{COAL-LIQUID MIXTURES}

\section{Background}

Coal-liquid mixtures consist of finely ground coal suspended in a liquid, such as oil or water, together with small amounts of chemical additives to improve stability and other physical properties. The primary purpose of coal-liquid mixtures is to make solid coal behave as an essentially liquid fuel that can be transported, stored, and burned in a manner similar to heavy fuel oil. The most mature coal-liquid mixture technologies are those using coal-oil and coalwater mixtures (CWM). Several of these technologies already have been offered commercially. Since coal-liquid mixtures are intended as a substitute for oil, their market penetration is heavily dependent on oil prices.

\section{Development History}

Initial development work on coal-oil mixtures (COMs) dates back to the last century (DOE, 1988). Extensive COM research was conducted in the United States during the 1940s because of wartime constraints on oil supply. More recent interest in COMs followed the 1973 OPEC oil embargo and the oil price hikes of the late 1970s. Utility and industrial boiler demonstrations using COMs were conducted in the United States, Japan, Sweden, and England between 1977 and 1981 . Over 20 COM preparation plants are currently operating or have been operated in various countries.

The first combustion tests of CWMs-also known as coal-water slurries (CWSs)-were conducted in the United States, Germany, and the former Soviet Union in the 1960s. There was active development of CWMs in the United States in the 1980s, with emphasis on developing technologies to prepare mixtures with desirable physical and chemical properties, demonstrating retrofit in existing boilers, and developing specialized equipment for handling and transporting slurries. During this period, a number of private companies were actively involved in, or planned to enter, the CWS business. All have subsequently gone out of business or abandoned commercialization of slurries as oil prices declined in the early $1980 \mathrm{~s}$.

\section{State of the Art}

Areas for further performance improvements in COMs depend on advanced coal beneficiation to further reduce sulfur and ash content and improved additives or other means of increasing the weight percentage of coal in the mixture. CWSs also are a potential alternative to premium fuels (oil and gas) being used in industrial and utility boilers and were offered commercially in the early 1980s. Cost studies suggest that slurries could be prepared and used economically with oil prices around $\$ 25$ to $\$ 30 / \mathrm{bbl}$, given a production facility of sufficient scale and the infrastructure required to handle the fuel. Such studies also indicate that slurries are economical if the differential in cost between heavy oil and slurry is $\$ 1.50$ per $10^{6}$ Btu (Addy and Considine, 1994). Present oil price forecasts, however, make it unlikely that coal-based 
substitutes will be competitive in the near to mid term. Nevertheless, one Pennsylvania utility (Penelec) is currently investigating cofiring its pulverized coal utility boilers with a CWS to provide 20 to 40 percent of fuel needs (Battista et al., 1994). This technology would allow the utility to purchase and utilize fine upgraded coal while reducing $\mathrm{NO}_{x}$ emissions with no boiler derating.

\section{Current Programs}

Much of the current work on coal-liquid mixtures is being funded, at least in part, by DOE. Activities range from fundamental research on mixture preparation and properties, through bench-scale preparation and combustion, to commercial-scale demonstrations. The emphasis in all these programs is on CWSs rather than COMs.

Fundamental research on CWSs is being conducted at Adelphi University, Carnegie Mellon University, and Texas A\&M University under the Coal Utilization Science program of DOE's AR\&TD activity. Topics under investigation include the combustion system atomization processes, modeling, and measurement of viscosity and surface properties. The Pennsylvania State University is conducting a superclean CWS program with support from DOE and the commonwealth of Pennsylvania to determine the capability of firing such slurries in an industrial boiler designed for firing heavy fuel oils, with no adverse impact on boiler rating, maintenance, reliability, and availability. DOE, through the University of North Dakota Energy and Environmental Research Center, also is supporting the development of refuse-derived fuel/coal slurry fuels. DOE is managing a boiler conversion program at the Pennsylvania State University for the U.S. Department of Defense, with the objective of developing commercial CWS technology. The program will provide a military base with a commercially engineered CWS conversion system for firing its oil/gas-fired boilers.

Demonstration projects using CWS include a CCT (Clean Coal Technology) Round V program to demonstrate clean coal diesel technology. The diesel system will use a CWS produced from Ohio coal by a two-stage coal cleaning and slurrying process. Another CCT program is demonstrating the combustion of injected coal in the tuyeres of two blast furnaces at Bethlehem Steel. Blast furnace coal injection technology, where granulated or pulverized coal is injected into a blast furnace in place of natural gas (or oil) as a fuel supplement or reductant to lower the coke rate and hot metal cost, may incorporate CWS technology in the future. A University of North Dakota project on power generation from an Alaskan coal-water fuel has demonstrated the preliminary process economics of a concentrated low-rank coal-water fuel. The second phase of the program is aimed at developing a low-cost indigenous replacement for the imported diesel fuel used in many native villages of the Alaskan interior.

While a specific breakdown of DOE funding for coal-liquid mixture R\&D is not provided in the FY 1995 budget request, the overall funding for the AR\&TD Coal Utilization Science program is projected to decrease from $\$ 3.1$ million in FY 1994 to $\$ 2.2$ million in FY 1995. Part of this decrease is due to a reallocation of some projects to other coal program budget lines. A more detailed discussion of DOE's advanced research budgets appears in Chapter 9. 


\section{Findings}

COM and CWS technologies are either commercially available or on the verge of commercialization. Aside from some niche market opportunities, the private sector currently has little current interest in adopting these technologies. However, if oil or gas prices increase significantly above current or projected near-term levels, COMs are available for commercial application. At that time, there may be a need for programs that assist the private sector in taking CWS technology to the marketplace.

\section{COALBED METHANE RECOVERY}

\section{Background}

The coal formation process occurs when organic debris is converted to coal and various by-products, including water and methane $\left(\mathrm{CH}_{4}\right)$ gas. The latter may be found in the coal itself or trapped in the strata surrounding the coal. For every ton of coal formed, as much as 5,000 cubic feet of "coalbed methane" may be generated in situ (DOE, 1994b). Coalbed methane liberated into mine workings by underground coal mining can be a serious safety hazard, since methane is highly explosive in volume concentrations of 5 to 15 percent. Thus, underground mines in the United States are required to maintain methane concentrations below 1 percent of the concentration of the air in the mine (CFR, 1988).

Methane has attracted recent attention as a greenhouse gas that may contribute to global warming (see Chapter 3). The Clinton adminstration's Climate Change Action Plan (Clinton and Gore, 1993) identifies coal mines as one of the primary sources of methane emissions in the United States and requires the EPA (U.S. Environmental Protection Agency) and DOE to launch a coalbed methane outreach program to raise awareness of the potential for cost-effective emissions reductions with key coal companies and state agencies. In addition, the Climate Change Action Plan requires DOE to expand its research, development, and demonstration (RD\&D) efforts to broaden the range of cost-effective technologies and practices for recovering methane associated with mining.

\section{State of the Art}

While all coal seams contain some methane, the highest levels of coalbed methane in the United States occur in seams in Virginia, West Virginia, Utah, and Colorado. To mine these gassy seams, mining companies have developed a number of techniques to eliminate or reduce the amount of methane liberated during mining. The primary technique is to design the mine ventilation system with enough capacity to keep the concentration at acceptable levels well below the lower explosive limit-generally less than 1 percent methane by volume. Other methods involve vertical drilling into the coal seam to vent methane before and after mining and drilling horizontally into the seam and venting the gas to the surface. There are instances where mining companies collect high-concentration methane and, after limited cleaning, sell the gas to a 
commercial pipeline. The economics of collection and sale to a user or distributor can either be based on a direct payback basis or justified by a reduction in mine ventilation costs.

\section{Current Programs}

Section 1306 of EPACT requires DOE to study barriers to coalbed methane recovery, to assess environmental and safety aspects of flaring coalbed methane liberated from coal mines, and to disseminate information on state-of-the-art coalbed methane recovery techniques to the public. DOE is further required to establish a coalbed methane recovery demonstration and commercial application program, with emphasis on gas enrichment technology. DOE requested $\$ 300,000$ in the FY 1994 budget for coalbed methane activities, but that funding was not approved. The administration's FY 1995 budget request includes coalbed methane recovery activities in the natural gas portion of the Fossil Energy program. As required by the Climate Change Action Plan (see above), EPA recently launched an outreach program to encourage coal companies to install methane recovery equipment at mines across the United States. The goal of this program is to reduce methane emissions from coal mines by at least 500,000 metric tons (25 billion cubic feet) by 2000 (Wamsted, 1994). DOE has developed a plan to expand RD\&D for methane recovery from coal mining; DOE and industry will cofund projects on a 50 percent cost-sharing basis. This activity will be coordinated with the EPA outreach program.

\section{Issues, Risks, and Opportunities}

Technology for the recovery of coalbed methane from gas streams with high methane concentrations is commercially available and practiced by the gas and mining industries where conditions justify the investment. However, the collection and sale of methane are not widespread in the coal mining industry because of a number of technical and commercial issues. These include ambiguities in mineral rights concerning gas ownership, trade-offs between the selling price of methane and tax credits to encourage investments, the dependence of methane recovery on gas concentration and porosity of the coal or strata, the quantity and quality of gas to be vented, and constraints on the underground mining technique used (e.g., room and pillar versus longwall).

Technology for the use or control of coalbed methane emissions in very dilute gas streams (methane concentration less than 1.0 percent) is not currently available. Low-quality mine gases must be upgraded or enriched for sale to a distribution system. In view of the importance of methane as a greenhouse gas (see Chapter 3), opportunities exist to encourage the utilization of dilute methane streams emitted from coal mines by developing relevant technologies.

Possible research areas include new techniques for methane separation and the combustion of very dilute methane streams. Separations of methane from dilute ventilation air by conventional methods is expensive and energy intensive. Research aimed at finding new materials for selective adsorption or selective diffusion through membranes is of interest (see Chapter 9). Ventilation air streams are too dilute to burn in conventional combustion equipment 
without use of additional fuel, which would generate additional greenhouse gases. Catalytic combustion systems offer some promise, and advances made for other applications are of interest (see, for example, Haggin, 1994).

\section{Findings}

Coalbed methane recovery is a commercially available technology that is being practiced where concentrations are sufficiently high and where merited by the return on investment or benefits to mining.

Technologies for the capture and use of dilute coalbed methane streams are not sufficiently mature for commercial implementation. Given the increased emphasis on reducing emissions of greenhouse gases, including methane from coal mining, there are potential research opportunities directed toward the recovery of coalbed methane from very dilute gas streams.

\section{REFERENCES}

Addy, S.N., and T.J. Considine. 1994. Retrofitting oil-fired boilers to fire coal-water-slurry: An economic evaluation. P. 341 in The Greening of Coal. Washington, D.C.: Coal \& Slurry Technology Association.

Battista, J.J., T. Bradish, and E.A. Zawadzki. 1994. Test results from the co-firing of coal water slurry fuel in a 32 megawatt pulverized coal boiler. P. 619 in The Greening of Coal. Washington, D.C.: Coal \& Slurry Technology Association.

CFR. 1988. Code of Federal Regulations, Title 30, Mineral Resources: Part 75-Mandatory Safety Standards-Underground Coal Mines. Washington, D.C.: Office of the Federal Register, National Archives and Records Administration.

Clinton, W.J., and A. Gore, Jr. 1993. The Climate Change Action Plan. Washington, D.C.: The White House.

DOE. 1988. Energy Technologies and the Environment-Environmental Information Handbook. U.S. Department of Energy, DOE/EH-0077. Washington, D.C.: DOE.

DOE. 1994a. FY 1995 Congressional Budget Request. U.S. Department of Energy,'DOE/CR0023, Vol. 4. Washington, D.C.: DOE.

DOE: 1994b. Meeting the Climate Change Challenge. U.S. Department of Energy, Office of Fossil Energy. Washington, D.C.: DOE. 
Feeley, T.J., W.B. Barnett, and R.E. Paper Hucko. 1994. Advanced physical coal cleaning for controlling acid rain emissions. Presented at 12th International Coal Preparation Congress, May 23-27, Cracow, Poland.

Haggin, J. 1994. Catalytic oxidation process cleans volatile organics from exhaust. Chemical and Engineering News 72(26): 42-43.

Hucko, R.E., B.K. Schimmoller, and P.S. Jacobsen. 1994. The prep plant of tomorrow: Different from yesterday, more different tomorrow. Coal Magazine. Apr.: 50-53.

Killmeyer, R.P., C.P. Maronde, B.R. Utz, and R.E. Hucko. 1994. The Initiation of Paper in the U.S. Department of Energy's Coal Preparation Process Research Facility. Paper presented at the 12th International Coal Preparation Congress, May 23-27, Cracow, Poland.

Wamsted, D. 1994. EPA urging methane recovery at coal mines. The Energy Daily, 22(72): 3. 


\section{Clean Fuels and Specialty Products from Coal}

Coal is currently a major source of fuel for power generation, industrial heat, and, on a smaller scale, manufacture of coke and by-product coal tar. In the mid to long term, anticipated increases in the cost of natural gas and petroleum relative to coal are expected to increase the incentive for expanded efforts to convert coal to ash-free, low-sulfur transportation fuels and, ultimately, gaseous fuels for domestic use (see Chapter 3). As natural gas prices increase, substitution of gas from coal in natural gas-fired power generation plants may become economic. Advanced combined-cycle and fuel cell power generation technologies will also require the conversion of coal to clean gaseous fuels. In addition to the above major uses, economical use of clean gaseous and liquid products from coal can provide a source of feedstock for chemicals production.

This chapter discusses the status of technologies for coal conversion to clean fuels and the role of the DOE in developing and promoting lower-cost, higher-efficiency processes to meet future needs. This discussion is divided into three major sections: gasification of coal, products from the gas obtained from coal gasification, and products from direct liquefaction and pyrolysis of coal. ${ }^{1}$ Opportunities for economic production of a range of coal-based products using coproduct systems, also known as coal refineries, is then addressed. The chapter concludes with the committee's major findings relating to clean fuels and specialty products from coal.

\section{GASIFICATION OF COAL}

\section{Background}

Conversion of coal to a gaseous fuel that can be cleaned and used in homes and commercial installations has been practiced for over 200 years. It was a major industry in the United States and abroad until the 1940s. During World War II, the manufacture of liquid fuels was practiced by Germany to provide military fuel, and in this context significant advances were made in gasification technology that formed the basis for present-day gasifiers. The increasing

\footnotetext{
'An extensive discussion of coal conversion technologies is provided in another National Research Council report on production technologies for liquid transportation fuels (NRC, 1990). The reader is referred to that report and the references therein for further details of conversion chemistry.
} 
availability of natural gas and petroleum in the United States and other industrialized countries resulted in the replacement of coal-based town gas with natural gas or heating oil. The oil embargo of 1973 and predictions of impending natural gas shortages, however, resulted in major industry and government programs in the United States and Europe to develop gasification systems for production of SNG from coal. This effort led to pilot plant studies incorporating many of the major engineering approaches for development of superior gasification technologies. However, when petroleum and gas prices fell and it became clear that domestic resources were adequate to provide low-cost natural gas at least through the year 2000 , the incentive for the construction of facilities for SNG production was eliminated, leaving a relatively few surviving commercial coal gasification systems. These were primarily aimed at manufacture of high-value products, such as methanol, ammonia, and chemicals. Today's emphasis on increased power generation efficiency, and the availability of high-performance gas turbines and fuel cells, have created a strong incentive for development of high-efficiency gasification systems specifically designed to provide fuel for power generation. These systems can differ from systems optimized to produce highly purified synthesis gas for catalytic conversion to chemicals and clean fuels in that dilution by methane and nitrogen is acceptable and a higher level of impurities can be tolerated.

\section{State of the Art}

The status of gasification processes of current interest that are either commercially available or have reached the stage of major pilot plant development is shown in Table 6-1.

Gasification processes can be divided into three major classes: entrained-flow, fluidizedbed, and moving fixed-bed. All involve operating pressures up to several hundred psi. For entrained-flow systems, powdered coal is generally first gasified with a mixture of steam and oxygen (or air) in a zone where the main part of the molten slag is collected. The hightemperature products require quenching or cooling prior to cleanup, with resulting loss of thermal efficiency. Entrained-flow gasification systems produce little methane, are relatively compact, and, because of the high operating temperature $\left(1040^{\circ} \mathrm{C}-1540^{\circ} \mathrm{C}\left[1900^{\circ} \mathrm{F}-2800^{\circ} \mathrm{F}\right]\right)$, involve short reaction times. Entrained solid gasifiers are insensitive to most coal properties as long as the coal can be pulverized to about 80 percent below 200 mesh (44 micron) size. Entrained-flow systems, most notably the Texaco units, have found commercial application during the past decade for production of synthesis gas for chemical syntheses. The Texaco, Shell, and Destec processes are commercial technologies developed primarily in the United States. As a result of the required high reaction temperature and resulting high oxygen consumption, this class of gasifier has inherently lower thermal efficiency than fluidized-bed and moving fixed-bed gasifiers. The gas produced is relatively free of tars, hydrocarbons heavier than methane, and nitrogen compounds. Because of their proven performance, entrained-flow gasifiers have been chosen for IGCC demonstrations both in the United States and overseas. Such demonstrations primarily address systems integration issues rather than gasifier development.

Fluidized-bed gasification systems operate at $760^{\circ} \mathrm{C}$ to $1040^{\circ} \mathrm{C}\left(1400^{\circ} \mathrm{F}\right.$ to $\left.1900{ }^{\circ} \mathrm{F}\right)$, depending on the reactivity of the feed coal and ash softening temperature, and have the potential 
for higher efficiency. Because the temperatures on exiting the gasifier are well matched to the requirements for hot gas cleanup systems, fluidized-bed gasifiers offer overall efficiency advantages relative to higher-temperature entrained-flow systems that require gas cooling prior to cleanup. Relative to moving bed gasifiers, fluidized-bed units offer higher coal throughput rates, which reduce unit size and cost. Thus, fluidized-bed gasifiers offer an attractive method for producing a wide array of products from coal-derived gas. While no high-pressure systems are classified as commercial technologies, it should be noted that the atmospheric version (Winkler) has been in commercial use for over 65 years. Demonstration programs are under way in Europe and the United States. As discussed later in the section on technical issues and opportunities, the low-temperature Exxon Catalytic Process, with modifications, may offer the potential for high efficiency, although this program is currently inactive. The lower-temperature, higher-pressure versions of fluidized-bed gasification processes produce methane as well as synthesis gas, which requires less oxygen and increases the efficiency. Due to the low temperatures, the residues (ashes) from fluidized-bed gasifiers are possibly less inert and may require more attention to their disposal in an environmentally secure repository. A special ash agglomeration section, as in the Tampella/U-Gas and KRW gasifiers, can reduce this problem.

In the moving fixed-bed gasification process, approximately 2 -inch $\times 1 / 2$-inch-sized coal moves down the reactor countercurrently to the gas flow. The countercurrent flow leads to higher efficiency. However, moving bed systems are more costly and more complex than stationary bed systems due to the equipment needed to maintain the flow of solids. Historically, the moving fixed-bed process is the most widely used gasification system. High temperatures above the oxidizing gas inlet decrease as the gases exchange heat and react with the incoming coal and exit temperatures are low. Some pyrolysis products (methane, light hydrocarbons, and tar) escape oxidation, and subsequent removal of the tar is required. The commercial Lurgi process yields an unfused ash clinker; however, a slagging version has been developed in cooperation with British Gas. A high-pressure version (6.9 MPa [1,000 psi]) with higher methane yields has been piloted. Use of in-bed limestone for sulfur capture is proposed, but hot gas desulfurization is also being considered. Because of the relatively long residence times and limitation on reactor diameter, moving fixed-bed units have lower coal throughput than is achieved with fluidized-bed units. Commercial moving bed gasifiers have capacities in the 800 to 1,000 tons/day range.

The Shell, Destec, and Texaco high-temperature entrained-flow gasifiers have a singletrain capacity, resulting from the small coal particle size and high operating temperature, of up to 2,000 tons of coal/day, corresponding to about $265 \mathrm{MW}$ of electricity. The high-temperature Winkler circulating fluidized-bed system planned for the European KoBra demonstration after the year 2000 has a planned capacity of about $300 \mathrm{MW}$ using brown coal. To date, Lurgi fixedbed units have a lower capacity than do entrained-flow units. This difference in capacity is subject to change with further development.

\section{Gasification Technology and IGCC Performance}

The first-generation U.S. IGCC systems are scheduled for demonstration in the ongoing CCT program (see Chapters 7 and 8 ) using the Destec and Texaco entrained-flow gasifiers with 
design power generation efficiencies of 38 and 40 percent, respectively. Demonstration of the Shell gasifier as part of an IGCC system is under way in the Netherlands, and a Prenflo system demonstration is under way in Spain. Another IGCC clemonstration project based on the moving bed British Gas/Lurgi slagging gasifier is included in DOE's CCT program but has not yet been contracted for. Also in the CCT program, a 100-MW IGCC system with a KRW fluidized-bed gasifier has been designed with an efficiency of 40.7 percent. Since all these systems make use of state-of-the-art $1300^{\circ} \mathrm{C}\left(2350^{\circ} \mathrm{F}\right)$ gas turbines, increases in efficiency to the 45 percent level projected for second-generation systems depend on the use of hot gas cleanup systems plus improvements in gasifier performance and optimized systems integration.

In addition to the method of contacting coal and oxidant (entrained-flow, fluidized-bed, or moving fixed-bed), important gasification choices include the use of air or oxygen, and hot or cold gas cleanup. Table 6-2 presents results of a study of the effects of these variables on efficiency using Illinois No. 6 coal in two gasifiers still in the development stage, namely, the $\mathrm{KRW}$ fluidized-bed system and the Asea Brown Boveri (ABB)/Combustion Engineering (CE) air-blown entrained-flow system, both using a General Electric MS7001 $\left(1300^{\circ} \mathrm{C}\left[2350{ }^{\circ} \mathrm{F}\right]\right)$ turbine (Gilbert/Commonwealth, Inc., 1994). ${ }^{2}$ Both are scheduled for demonstration in the DOE CCT program.

The performance estimates in Table 6-2 show an overall thermal energy loss of approximately 15 to 20 percent in the gasification and gas cleanup steps. This results in a penalty of about five to 10 percentage points in electrical generating efficiency. Other findings from this study are as follows:

- When hot gas cleanup is used, changing from air to oxygen results in an efficiency reduction of approximately one percentage point (Cases 2 and $2 a$ ). This stems primarily from the energy requirements of oxygen production.

- For the air-blown systems, use of hot gas cleanup rather than cold gas cleanup results in an energy savings of 5 percent and a corresponding electrical efficiency gain of approximately two percentage points (Cases 1 and 1a, plus 3 and 3a). The efficiency advantage for hot gas cleanup is expected to be lower for oxygen-blown systems because of their lower mass flow rates and sensible heat loads.

- The most efficient system in this comparison is the air-blown fluidized-bed gasifier with hot gas cleanup plus in-bed sulfur removal (Case 1a). A gain of over three percentage points in net generating efficiency (HHV) is indicated compared to the oxygen-blown entrainedflow gasifier with cold gas cleanup (Case 3) of the type currently under demonstration. However, carbon dioxide emissions increase by 4.5 percent due to the calcination of limestone in the gasifier.

\footnotetext{
${ }^{2}$ The KRW air-blown in situ desulfurization version of the KRW process is scheduled for demonstration under CCT-IV at the Sierra Pacific Power Company. For this process, using western coal, the ash is sintered and removed as agglomerate. The $\mathrm{ABB} / \mathrm{CE}$ process is scheduled for demonstration at City Water, Light and Power in Springfield, Illinois, with CCT cost sharing. The first stage of the entrained-flow system operates at $1480^{\circ} \mathrm{C}$ to $1650^{\circ} \mathrm{C}(2700$ to $\left.3000^{\circ} \mathrm{F}\right)$ and produces a molten slag. The second-stage gas leaves at $1070^{\circ} \mathrm{C}\left(1960^{\circ} \mathrm{F}\right)$ and is then cooled to allow hot-gas cleanup $\left(540^{\circ} \mathrm{C}\right.$ to $590^{\circ} \mathrm{C}\left[1000^{\circ} \mathrm{F}\right.$ to $\left.\left.1100^{\circ} \mathrm{F}\right]\right)$ with the General Electric zinc titanate/zinc ferrite sulfur removal and candle filtration.
} 
The efficiency penalty for coal gasification can be attributed to losses involved in cooling the gasification product, the temperature cycling required by the gas cleanup system, the pressure drops incurred by all gas cleanup systems, and by flow through the gasification reactor. Continued R\&D can likely reduce these losses, as discussed below.

\section{Technical Issues and Opportunities}

Improvements in the integration of coal gasification with advanced power generation systems are of greatest current interest. In the mid- to long-term periods (2006 through 2040), the production of hydrogen, clean low- and medium-Btu gaseous fuels for industrial and utility use, and synthesis of liquid fuels and chemicals are expected to be major potential applications for coal gasification. For both power generation and fuels production, greenhouse gas concerns are expected to greatly increase the emphasis on improved efficiency. Thus, new and improved gasification processes with higher thermal efficiency will be required.

The inherent problem of coal gasification is the high-temperature required to achieve a practical rate of reaction of coal with steam. The temperature varies-depending on the reactivity of the coal and the choice of gasifier-from about $800^{\circ} \mathrm{C}$ to $1650^{\circ} \mathrm{C}\left(1500^{\circ} \mathrm{F}\right.$ to $\left.3000^{\circ} \mathrm{F}\right)$ for uncatalyzed gasification. If the raw exit gases are cooled to the low temperature conventionally required for removal of hydrogen sulfide $\left(\mathrm{H}_{2} \mathrm{~S}\right)$ and other contaminants, losses in useful heat are incurred despite use of bottoming cycles and transfer of heat to other process streams.

These losses can be minimized by reducing cyclic heating and cooling of the gas. Several approaches are possible. Hot cleanup of the gasification product to minimize or eliminate cooling is currently limited to the temperature range of $650^{\circ} \mathrm{C}$ to $760^{\circ} \mathrm{C}\left(1200^{\circ} \mathrm{F}\right.$ to $\left.1400^{\circ} \mathrm{F}\right)$ and is primarily applicable to integrated gasification gas turbine or fuel cell systems for power generation. In these applications it has the potential for savings of one to three efficiency points relative to cold gas cleanup and is a major part of the DOE coal R\&D program (see Chapter 7). Lowering the gasification temperature reduces these losses, but it also increases the direct formation of methane. The lowering of gasification temperature by increasing the reactivity of the coal (char) is achievable by use of catalysts; this has been studied extensively and piloted by Exxon. Acceptable reaction rates were obtained at temperatures down to $625^{\circ} \mathrm{C}$ to $650{ }^{\circ} \mathrm{C}$ $\left(1160^{\circ} \mathrm{F}\right.$ to $\left.1200^{\circ} \mathrm{F}\right)$. This approach remains a promising opportunity for cost reduction.

While methane is an undesirable product for hydrogen or syngas manufacture, its direct formation is advantageous for both SNG manufacture and power generation, since the volumetric heating value of the fuel gas is higher and cleanup and compression energy requirements are reduced. The direct formation of methane during gasification, or by prior pyrolysis, reduces oxygen and steam requirements and reduces the volume and heat capacity of the fuel gases. Use of oxygen instead of air further reduces the heat capacity and volume of the gaseous mixture. The use of oxygen, rather than air, for production of SNG, hydrogen, and synthesis gas-based liquid fuels and chemicals also eliminates dilution from atmospheric nitrogen; most gasification systems have been developed for oxygen use.

The manufacture of oxygen requires energy for air compression to drive the separation process and also represents a major capital expense. For gas turbine power generation, therefore, air-blown systems appear attractive. However, the larger volume of gas will increase both 
temperature cycling and pressure drop losses. Oxygen-blown systems produce about half the gas volume of an air-blown system but consume energy for oxygen manufacture. The cold gas cleanup losses (approximately 1 percent) can also be reduced by tailoring cold gas cleanup to match the emissions requirements for power generation, which are considerably less demanding than for catalytic synthesis of SNG or liquids. For fuel cell systems, to avoid electrolyte degradation, a high level of cleanup might be economically desirable.

For use in clean fuel manufacture, air-blown systems that result in about 50 percent nitrogen dilution are impractical. Dilution by methane, while undesirable for stand-alone syngas plants, presents less of a problem in plants when electricity or steam generation can make good use of the waste gas from liquids and hydrogen manufacture. Oxygen-blown systems are, therefore, needed for these applications. As previously discussed (Table 6-2), the loss in power generation efficiency for oxygen-blown versus air-blown systems is about 1 percent for the KRW fluidized-bed system provided that hot gas cleanup is successful, and this small difference can likely be reduced by further research and optimization. With this small difference, the incentive for development of specialized air-blown systems is not clear.

No single gasification process is likely to be optimal for all applications; the wide range of coal properties will, in itself, affect the choice. An overriding need is for mechanical simplicity. Solid reaction systems are notoriously difficult to extrapolate, making development of any system to commercial scale a costly operation (about $\$ 0.5$ billion for each process). Thus, careful selection of $R \& D$ and demonstration programs to be pursued is extremely important. For maximum efficiency, the following general guidelines are offered: minimum gasification temperature to reduce temperature cycling and oxygen consumption and to maximize methane production. Production of fused ash to minimize solid waste removal/disposal problems also is an important goal. The use of catalysts to allow lower-temperature operations appears attractive to achieve significant improvements in efficiency and to minimize the production of tars. The cost of using catalysts would be a disadvantage.

\section{Current Programs}

DOE's participation in R\&D and demonstration of gasification technologies falls into three categories: CCT programs, ${ }^{3}$ development programs, and advanced research programs related to gasification. The last two fall within the scope of the coal $R \& D$ program in DOE's Office of Fossil Energy.

The CCT programs summarized in Table 6-3 all involve gasification for power generation. The gasifiers, while constituting a fraction of the total program cost, are an essential feature of each demonstration. The gasification systems being demonstrated represent technologies of commercial interest to companies within the United States, including affiliates of overseas companies. Overall, the program should provide a basis for commercialization of IGCC power generation plants, as well as a framework for future advances in gasification efficiency and cost reductions for power generation.

Of the seven programs, five plan to use the currently experimental hot gas cleanup-one

\footnotetext{
${ }^{3}$ The general nature of CCT programs is discussed in Chapter 8.
} 
on a 10 percent slipstream. Use of cold gas cleanup reduces efficiency by approximately two percentage points (see Table 6-2). Four of the programs will use air as the oxidant with an efficiency advantage of approximately 1 percent over the use of oxygen. These advantages are specific to dedicated power generation systems and would not be applicable to the supply of hydrogen or syngas for coproduction of liquid fuels.

Recent DOE budgets for surface coal gasification are shown in Table 6-4. The major expense is for construction of facilities for development of an Advanced Hybrid Gasification System. This facility is designed for development of an air-blown moving fixed-bed system with hot gas cleanup. The proprietary CRS Sirrine Engineers, Inc., PyGas ${ }^{\mathrm{TM}}$ staged gasifier has been selected for development with 20 percent industry cost share (CRS Sirrine Engineers, Inc., 1994). Given the committee's concern regarding optimization of gasification systems and the central role of the PyGas ${ }^{\mathrm{TM}}$ staged gasifier in the DOE program, the proposed technology is discussed below in some detail.

Coal, air, and steam are contacted in a cocurrent flow duct where the temperature rises to $815^{\circ} \mathrm{C}$ to $980^{\circ} \mathrm{C}\left(1500{ }^{\circ} \mathrm{F}\right.$ to $\left.1800^{\circ} \mathrm{F}\right)$ and pyrolysis of the coal occurs. The hot pyrolyzed coal (char) falls to the top of a countercurrent fixed-bed gasification section, and dry ash is withdrawn at the bottom. Remaining tars are cracked in a tar cracking zone where the temperature is increased by addition of air. The pyrolyzed gases join the hot gas leaving the countercurrent section to produce a $112 \mathrm{Btu} / \mathrm{dry}$ standard cubic foot gas stream. The product gas temperature is expected to be around $815^{\circ} \mathrm{C}\left(1500^{\circ} \mathrm{F}\right)$. In Phase I of the project, limestone will be included to capture sulfur in the bed. The spent lime, which exceeds the amount of coal ash, must be treated to oxidize the calcium sulfide before disposal. Use of hot gas cleanup is proposed for a later phase of the program. This system appears to have potential for efficient integration with hot gas cleanup in a power generation system. However, because it is air-blown it would not be a good choice for coproduction of clean gaseous or liquid fuels.

In addition to the programs given in Table 6-4, there is a program for developing the Wilsonville facility centered around hot gas cleanup. In January 1992 the hot gas particulate removal test facility at Wilsonville, Alabama, was expanded to include system development and integration studies for advanced power systems and was renamed the Wilsonville Power Systems Development Facility. The facility could ultimately be reworked for gasifier research. The proposed FY 1995 budget for this facility is $\$ 12.9$ million.

The two gasification research programs suffered a 58 percent reduction in funding in FY 1994, with a further reduction proposed in the FY 1995 budget request. These small programs (\$0.8 million) are not sufficient to take advantage of the opportunities identified for further improvements in efficiency of gasification systems. Some additional discussion of advanced research opportunities for gasification can be found in Chapter 9.

\section{PRODUCTS FROM COAL-DERIVED GAS}

The raw gaseous products from coal gasification include hydrogen $\left(\mathrm{H}_{2}\right)$, carbon monoxide (CO), carbon dioxide $\left(\mathrm{CO}_{2}\right)$, water $\left(\mathrm{H}_{2} \mathrm{O}\right)$, ammonia $\left(\mathrm{NH}_{3}\right)$, hydrogen sulfide $\left(\mathrm{H}_{2} \mathrm{~S}\right)$, nitrogen $\left(\mathrm{N}_{2}\right)$, methane $\left(\mathrm{CH}_{4}\right)$, and, for the lower-temperature processes, higher hydrocarbons and tar. For conversion to "clean" gas suitable for combustion in simple equipment or for further 
processing to other clean fuels or chemicals, the mixture is scrubbed to consist primarily of $\mathrm{H}_{2}$, $\mathrm{CO}, \mathrm{CH}_{4}$, and $\mathrm{N}_{2}$. This type of "synthesis gas" (syngas) mixture is currently of industrial importance for production of commodity chemicals and, to a growing extent, production of fuels. Natural gas is currently the dominant feedstock for production of syngas, with a large, continuing industrial and international R\&D activity in this field. In this section the following major product categories are discussed: hydrogen, synthetic natural gas, methanol and other oxygenated products from synthesis gas, and products from F-T (Fischer-Tropsch) synthesis. The costs presented are based on the standard utility financing used by DOE. Costs would be $\$ 6$ to $\$ 10 / \mathrm{bbl}$ higher for liquid feed production from coal if conventional petroleum industry financing were assumed (see Glossary).

\section{Hydrogen Production}

Major uses for hydrogen include ammonia manufacture for fertilizers and the refining of petroleum liquids with low hydrogen and high sulfur content. Hydrogen is also required to convert fossil resources into transportation fuels, since the hydrogen-to-carbon ratio for liquid transportation fuels is approximately two, compared to less than one for coal and slightly greater than one for petroleum tars.

The standard technique for hydrogen manufacture from natural gas or by coal gasification is to employ the water/gas shift reaction:

$$
\mathrm{CO}+\mathrm{H}_{2} \mathrm{O} \rightarrow \mathrm{CO}_{2}+\mathrm{H}_{2}
$$

Production of hydrogen is favored by low temperatures, but satisfactory reaction rates currently require a temperature of $300^{\circ} \mathrm{C}$ to $700^{\circ} \mathrm{C}\left(570^{\circ} \mathrm{F}\right.$ to $\left.1290^{\circ} \mathrm{F}\right)$. In addition, a high level of acid gas $\left(\mathrm{H}_{2} \mathrm{~S}, \mathrm{CO}_{2}\right.$, hydrogen chloride [HCl]) removal is needed to maintain catalyst reactivity. Hydrogen can also be separated from synthesis gas by cryogenic distillation. Another alternative for hydrogen production is to develop processes for the production of SNG, methanol, or liquid fuels that accomplish the shift of $\mathrm{H}_{2} / \mathrm{CO}$ mixtures in situ, thereby avoiding energy losses incurred by heating and cooling, the shift reaction, and subsequent removal of $\mathrm{CO}$ and $\mathrm{CO}_{2}$ from the product stream. Pressure swing methods for hydrogen separation are advantageous principally for small- and medium-scale applications.

If pure hydrogen could be obtained economically as a coproduct from the coal-derived fuel gas supplied for electric power generation, it might be used for high-efficiency fuel cell operation, hydrogenation of by-product coal pyrolysis liquid, direct coal liquefaction, or sold for the many conventional applications of hydrogen. New materials to allow efficient, low-cost separation of hydrogen from coal-derived gas by selective membrane diffusion offer performance enhancements (NRC, 1993), as discussed further in Chapter 9.

\section{Synthetic Natural Gas Production}

SNG is produced from gasified coal by a set of reactions of $\mathrm{CO}, \mathrm{CO}_{2}, \mathrm{H}_{2}$, and $\mathrm{H}_{2} \mathrm{O}$ over a catalyst to form methane. While the stoichiometry of the reaction is

$$
\mathrm{CO}+3 \mathrm{H}_{2} \rightleftarrows \mathrm{CH}_{4}+\mathrm{H}_{2} \mathrm{O}
$$


in the presence of catalysts, the interchange between the feed components can be rapid and controlled by thermodynamic equilibrium, such that the feed $\mathrm{H}_{2} / \mathrm{CO}$ ratio can be much lower than the stoichiometric $3 / 1$ ratio. While the above methane synthesis reaction is highly - exothermic, the gasification reactions to form synthesis gas are about equally endothermic, and the balancing of these reactions to minimize thermal losses from heating and cooling is essential for achievement of high efficiency. A large number of catalysts and systems have been studied with the goal of minimizing cost. An extensive discussion of SNG technology can be found in a report from the DOE Coal Gasification Research Needs Working Group (COGARN, 1987).

The one commercial SNG facility in the United States, the Great Plains plant in North Dakota, was built in the late 1970s by a consortium of natural gas companies in anticipation of constraints on natural gas supply and associated price rises. Despite the low cost of coal today and technically satisfactory operation, the plant is only profitable because contractual product prices are higher than the market price and a large portion of the capital costs is borne by the federal government. SNG is also produced in South Africa, and China plans to build a $\$ 220$ million plant in Henan province to produce $40 \mathrm{Mcf} / \mathrm{day}$ of SNG, with over 20 percent of the coal gas destined for use as petrochemical feedstock (Oil and Gas Journal, 1994).

The Great Plains plant uses 14 Lurgi dry bottom gasifiers followed by cold gas cleanup to reduce sulfur content to less than $1.0 \mathrm{ppm}$. The $\mathrm{H}_{2} / \mathrm{CO}$ ratio produced is around 2.0 , while for the higher-temperature British Gas Lurgi slagging gasifier the ratio is 0.46 , with ratios for other gasification systems falling between these limits. Advanced catalytic systems for directly converting the low $\mathrm{H}_{2} / \mathrm{CO}$ ratio gas from coal gasification have been an active $\mathrm{R} \& \mathrm{D}$ area. Goals include improvement in sulfur tolerance by appropriate choice of catalyst and operating conditions, better reactor temperature control, and avoidance of carbon formation favored by low-hydrogen-content fuel gas. ${ }^{4}$ It has been estimated that when commercialized these advanced technologies, together with limited work on improvements in the removal of acid gases, will reduce SNG costs by 25 percent for stand-alone plants using western coal (COGARN, 1987).

For the year 2010, EIA (Energy Information Administration) projects a wellhead price for natural gas of $\$ 3.50 / \mathrm{Mcf}$ (EIA, 1994), and continued increases in price may be expected past this date as a result of resource limitations. Substitution of coal-generated low- and medium-Btu gas for natural gas for power generation and industrial use could make additional supplies of natural gas available for domestic and commercial consumers. Thus, the need for major dedicated SNG manufacture could well be delayed beyond the year 2021 .

Currently there are no DOE programs budgeted specifically for SNG production. However, since the major cost and energy consumption are incurred by the gasification step, opportunities for improvement are similar to those for oxygen-blown advanced IGCC and fuel cell systems. A program aimed at improving gasification thermal efficiency could be applied to both uses, providing an additional incentive for an integrated gasification program.

\footnotetext{
${ }^{4}$ Methane is also produced noncatalytically in low-temperature gasification by thermal equilibration. The Exxon fluidized-bed catalytic gasification process makes use of this reaction with cryogenic separation of the methane produced $\left(15\right.$ to 20 volume percent of gas at $\left.650^{\circ} \mathrm{C}\left[1200^{\circ} \mathrm{F}\right]\right)$ and recycle of unconverted feed. Methane can also be produced from coal pyrolysis, and lower-temperature processes can provide up to 20 percent methane by volume in the gasifier product. High-temperature entrained-flow processes produce little methane.
} 


\section{Liquid Products from Synthesis Gas}

By careful choice of catalyst and conditions, synthesis gas can be reacted to produce higher hydrocarbons and oxygenates such as methanol. These products are useful for commodity chemicals, are of increasing interest for use as transportation fuels, and have been considered for production of storable supplementary fuel for IGCC electric power plants (EPRI, 1984; Tam et al., 1993).

The reaction between carbon monoxide and hydrogen to produce paraffinic oxygenates or hydrocarbons is extremely exothermic (Probstein and Hicks, 1982). The heat evolved is approximately 20 percent of the heat of combustion of the product and, because of the narrow temperature range over which the catalysts provide satisfactory selectivity to the desired product, control of reaction temperature is a major engineering challenge. The difference between the several catalytic processes in use or under development is largely related to differences in approach to temperature control and choice of catalyst.

\section{Methanol}

Methanol has been a major commodity for many years, with principal uses in the chemical industry and as a solvent. It can also be used as a motor fuel and, with the requirement for inclusion of oxygenates in gasoline, its use for preparing oxygenated components by reaction with olefins has grown rapidly. Its direct use as a gasoline blending agent is limited by its relatively low solubility in gasoline and its tendency to be extracted by any water present in the gasoline distribution system. Its use as the primary fuel component offers good performance but is limited by cost in competition with imported petroleum, a potential problem with formaldehyde emissions, and the difficulties of establishing an adequate distribution system and availability of automotive systems designed to use this fuel. Other limitations of methanol are its high toxicity, potential reaction with elastomers used in the automobile fuel system, the fact that it burns with an invisible flame, the potential for ground water pollution, and a limited driving range because of the low energy content per unit volume.

Methanol is made by the catalytic conversion of syngas at about $250^{\circ} \mathrm{C}\left(480^{\circ} \mathrm{F}\right)$ and a pressure of 60 to 100 atmospheres. Both coal and natural gas can be used as syngas sources. The current commercial processes use a fixed-bed catalytic reactor in a gas recycle loop. There are a wide range of mechanical designs used to control the heat released from the reaction. Lurgi and Imperial Chemical Industries technologies currently dominate, but other designs are offered by Mitsubishi, Linde, and Toyo corporations. New developments in methanol technology include use of a liquid-phase slurry reactor for methanol synthesis and fluidized-bed methanol synthesis being developed by Mitsubishi Gas Chemical. Liquid-phase slurry reactors offer improved control of temperature and are of considerable interest for both methanol and F-T hydrocarbon production. A DOE-owned liquid-phase slurry reactor plant at LaPorte, Texas, has been operated with industry cost sharing for a number of years. A DOE-supported demonstration plant is now being built by Eastman Chemical at Kingsport, Tennessee. In the fluidized-bed design a fine catalyst is fluidized by syngas. Better contact between syngas and catalyst gives a higher 
methanol concentration exiting the reactor, which reduces the quantity of recycle gas, the recycle compressor size, and the heat exchange area in the synthesis loop.

A study on production technologies for liquid transportation fuels (NRC, 1990) provides some perspective on costs of methanol production using both coal and natural gas as syngas sources. Natural gas at current prices is by far the lowest-cost feed, but at a delivered natural gas price of greater than $\$ 4$ to $\$ 5 / \mathrm{Mcf}$, coal gasification was judged to be competitive.

\section{Methanol-Derived Fuels}

There has been extensive industrial $R \& D$, in the United States and overseas, on processes to convert methanol to gasoline, olefins, and diesel fuel (NRC, 1990). Major participants include Mobil Research and Development Corporation, Union Rheinische Braunkohlen Krafstoff AG, Uhde Gmbh, Haldor Topsoe, Mitsubishi, and Lurgi. Technologies for the conversion of methanol to gasoline have been demonstrated at scales of 1 to $100 \mathrm{bbl} / \mathrm{day}$, and the Mobil process operates commercially in New Zealand producing 14,500 bbl/day of gasoline from syngas derived from natural gas rather than coal. Conversion of methanol to olefins has been demonstrated in Germany at a $100 \mathrm{bbl} /$ day scale; high-quality gasoline is also produced. At present, however, new plants for hydrocarbon fuel production from natural gas use the F-T synthesis, indicating no current major advantages for prior synthesis of methanol.

Production costs for imported methanol manufactured from overseas natural gas at $\$ 1.00 / \mathrm{Mcf}$ have been estimated (NRC, 1990) at $\$ 29 / \mathrm{bbl}$ equivalent crude oil cost (for gasoline equivalent). This cost is approximately competitive with methanol production from coal using advanced technology and coproduction with electric power (Tam, 1993). Even when domestic natural gas prices rise to a level where dedicated production from coal could compete economically, natural gas is expected to remain the lowest-cost syngas source for methanol production due to the large overseas supply of very low cost natural gas. However, as discussed later in the section on coal refineries and coproduct systems, coproduction with gasification combined-cycle power generation might be competitive with imported methanol.

While there is extensive industry activity on methanol synthesis starting with natural gas and using synthesis gas with the stoichiometric $\mathrm{H}_{2} / \mathrm{CO}$ ratio of 2.0 and low or very low sulfur content, there is relatively little activity on development of once-through processes using low $\mathrm{H}_{2} / \mathrm{CO}$ ratios and sulfur concentrations achievable with hot gas desulfurization. Such a process could be more efficient and advantageously integrated with coproduction of electricity.

\section{F-T Synthesis}

The F-T process reacts and polymerizes synthesis gas to produce a wide range of products: light hydrocarbon gases, paraffinic waxes, and oxygenates. Further processing of these products is necessary to upgrade the waxy diesel fraction, the low-octane-number gasoline fraction, and the large amount of oxygenates in the product water. A premium diesel fuel can be manufactured from the higher-molecular-weight hydrocarbons and the wax. The gasoline boiling range fraction has low octane number and requires more substantial upgrading to produce 
useful motor fuel. The distillation of high-molecular-weight products can be adjusted by choice of catalyst and operating conditions; wax produced as an intermediate is hydrocracked to produce a high cetane product. Greatest current interest is in the production of high-molecular-weight material for diesel and jet fuels, for which the low sulfur and high hydrogen content (compared to petroleum fractions) commands a premium price.

As with methanol, there is active industrial interest in the use of low-cost overseas natural gas to manufacture F-T synthesis products. The largest commercial activity with coal feed is by the South African Coal, Oil, and Gas Corporation (Sasol) in South Africa (NRC, 1990). Most of the R\&D in the United States on F-T processes has been conducted by Exxon. Important research areas are in catalyst development and optimization of processing conditions. Highlights of F-T development and commercialization activities are summarized in Table 6-5. For production of both methanol and hydrocarbons, the slurry process has been a focus of DOE research since it can accept the low-hydrogen/carbon monoxide synthesis gas produced from coal without the additional step of shifting the ratio required by the traditional fixed-bed systems. Success of this DOE approach has been demonstrated in a large-scale pilot plant at LaPorte, Texas, with joint DOE/industry funding.

While there is an active international R\&D program on F-T for use in remote natural gas locations, improved catalysts and process conditions for once-through processes with electricity as a coproduct may offer research opportunities specific to coal.

The results of DOE-sponsored design and systems studies on the cost of coal liquids production for stand-alone indirect liquefaction plants and for coproduction of coal liquids with gasification-based power generation are discussed below (see Coal Refineries and Coproduct Systems).

\title{
PRODUCTS FROM DIRECT LIQUEFACTION AND PYROLYSIS OF COAL
}

\author{
Direct Liquefaction
}

\section{Background}

In direct liquefaction, hydrogen is added to coal in a solvent slurry at elevated temperatures and pressures. ${ }^{5}$ The process was invented by Friedrich Bergius in 1913 and was commercialized in Germany and England in time to provide liquid fuels during World War II. The first U.S. testing of direct liquefaction processes followed World War II (Kastens et al., 1949); efforts in the area declined when inexpensive petroleum from the Middle East became available in the early 1950s. Interest revived when the Arab oil embargo of 1973 caused high oil prices, resulting in increased federal funding for such research. A variety of process concepts were examined on a small scale (10 to 20 tons/day), and three-Solvent Refined Coal, Exxon Donor Solvent, and H-Coal-were tested on a large scale (200 to 300 tons/day) in the late 1970s and early 1980s (NRC, 1990). The DOE provided much of the funding for these successful

\footnotetext{
${ }^{5}$ Direct liquefaction is generally believed to be 5 to 10 percent higher in efficiency than indirect liquefaction because of lower consumption of gasified coal (Stiegel, 1994).
} 
demonstrations, but none of the processes proved economical when oil prices fell in the early 1980s. Overseas, Veba Oil and others built and operated a large-scale pilot plant at Bottrop, Germany, in the late 1970 s and early 1980s. The facility is currently being used to hydrogenate chlorinated wastes. This facility was funded primarily by the German government. Demonstration of the liquid solvent extraction process developed by the British Coal Corporation is continuing at the Point of Ayr Plant in Wales with both industrial and government support. In the late 1980s the Japanese operated a 50-ton/day liquefaction plant in Australia (NRC, 1990).

\section{State of the Art}

Products of direct coal liquefaction can be refined to meet all current specifications for transportation fuels derived from petroleum. Major products are likely to be gasoline, propane, butane, and diesel fuel. Production of high-quality distillate fuels requires additional hydrogen to decrease smoking tendency and to increase cetane number for use in diesels.

High octane is achieved by the high aromatic content of the liquids. At one time, this was considered to be an advantage; however, the CAAAs (Clean Air Act amendments) of 1990 place sharp limits on the aromatic content of motor fuels in the United States. Fortunately, the benzene content of gasoline made from coal is extremely low; the concentration of other aromatics can be reduced by hydrogenation to produce naphthenes at a modest increase in cost. This increases the volume of the products, decreases the octane number, and increases process hydrogen consumption.

The projected cost for direct coal liquefaction has dropped by over 50 percent since the early 1980s (Lumpkin, 1988). Recent improvements in economics cannot be attributed to any single breakthrough but rather to the accumulation of improvements over several years of operation, notably the following:

- A more effective and reliable process was developed to remove solids from the liquid product by controlled precipitation, replacing a filtration process.

- A second catalytic reactor was added to improve control over the chemistry of liquefaction. This reactor was first installed downstream of the solids removal and distillation systems; moving the reactor upstream further improved operation.

- Some of the recycled liquid used to slurry the feed coal was bypassed around the solids removal unit, increasing the efficiency of the unit.

- Improved catalysts were added to both the first and second reactors.

This series of modifications led to higher liquid yields, improved conversion of nondistillable liquids, less rejection of energy along with discarded coal minerals, and increased throughput relative to early two-stage systems. The success of this evolution shows that steady R\&D can achieve major technological advances over time. The current U.S. direct liquefaction technology appears to be the best for U.S. coals, but work continues overseas with emphasis on other coals. All of the foreign projects have had the bulk of their financing contributed by government. 


\section{Current Programs}

U.S. research into direct coal liquefaction continued after the big pilot plants were abandoned in the 1980s, but both industrial and DOE activities have steadily decreased with time. Small test units capable of continuous operation for sustained periods of time were available at Hydrocarbon Research, Inc., Exxon, Lummus-Crest, the University of Kentucky, and Amoco Corporation, but today are either shut down or only in limited use. The Advanced Coal Liquefaction R\&D Facility in Wilsonville, Alabama, operated full-time through 1991. Hydrocarbon Research, Inc., started up a smaller facility in the second half of 1992 under DOE sponsorship. The unit operates approximately half-time, but funding beyond 1994 is uncertain. Research at West Virginia University on the production of coal-derived precursors using solvent extraction techniques as carbon product feedstocks has been supported by DOE. However, DOE funding for advanced research in direct liquefaction has decreased in recent years (see Chapter 9).

\section{Technical Issues, Risks, and Opportunities}

A 1989 assessment of research needs conducted by DOE's Office of Program Analysis outlined a comprehensive program aimed at bringing down the cost of direct liquefaction (Schindler, 1989). Industry participants in the aforementioned study stressed the need for federal funding of a large-scale pilot plant capable of processing 150 tons or more of coal per day, but such a unit was never funded. In addition, funding of intermediate-size flow units of the size of the Hydrocarbon Research, Inc., facility was recommended to test changes in process configuration at reasonable cost. Smaller pilot plants are needed to evaluate catalysts, explore operating conditions, and provide low-cost testing of new ideas.

A design and system analysis study, based on runs at the DOE Wilsonville plant, was carried out by a Bechtel-Amoco team under contract to PETC (DOE, 1993b) ${ }^{6}$ Using Illinois No. 6 coal (bituminous), the equivalent crude price was approximately $\$ 33 / \mathrm{bbl}$, compared to estimates of $\$ 44 / \mathrm{bbl}$ prepared for an earlier study (NRC, 1990). This cost reduction results from the incorporation of more recent results from the DOE Wilsonville plant, improved gasification, and from inclusion of 3 percent inflation in the DOE-sponsored estimates. The earlier estimates assumed 10 percent return and did not include inflation. If inflation were eliminated from the current DOE-sponsored calculations, the equivalent crude cost would be increased by approximately $\$ 5 / \mathrm{bbl}$. An extension of the Bechtel-Amoco study will be based on lower-cost Wyoming coal and is expected to reduce the equivalent crude costs to slightly less than $\$ 30 / \mathrm{bbl}$. On the basis of achievements to date, there is now optimism at DOE and among some industry groups that the $\$ 25 / \mathrm{bbl}$ target (in 1991 dollars) set by DOE (DOE, 1993a) may be attainable by sustained R\&D and continued optimization studies.

The 1989 assessment (Schindler, 1989) also recommended a broad range of fundamental and exploratory research, based on the recognition that possible improvements to the current

\footnotetext{
${ }^{6}$ This study assumed $n$th plant costs with 3 percent per year price inflation over the plant life, 25 percent owner equity with 15 percent return, and 8 percent interest charges for the 75 percent loan.
} 
technology may be limited but that advances in conversion chemistry may bring down the cost of liquid fuels produced from coal to be competitive with petroleum products. Possible approaches to conversion chemistry that might achieve costs below the current $\$ 25 / \mathrm{bbl}$ goal include low-pressure reaction (2.17 $\mathrm{MPa}$ [300 psig] or less), direct use of gasifier product, use of low-cost subbituminous coal or lignite, removal of oxygen in coal as carbon dioxide, and elimination of product hydrocarbon gases (increased selectivity).

Integration of direct coal liquefaction with an existing petroleum refinery could take advantage of existing facilities and ease the transition between petroleum and coal feedstock. DOE sponsored work on simultaneous processing ("coprocessing") of coal with heavy petroleum fractions in an ebullated-bed hydroprocessing reactor. One CCT program submission utilizing this technique was selected for funding but was unable to find the private sector funding needed to proceed.

\section{Coal Pyrolysis}

Pyrolysis of coal dates back to the eighteenth century, using temperatures below $700{ }^{\circ} \mathrm{C}$ $\left(1290^{\circ} \mathrm{F}\right)$ in fixed- or moving fixed-bed reactors. The primary product was a low-volatile smokeless domestic solid fuel, although the value of the liquid products was also soon recognized. During the 1920 s and 1930 s there was a great deal of $R \& D$ in low-temperature processes, but interest dwindled in the mid-1940s when gas and oil became readily available at low prices. With the oil embargo and increased oil prices of the early 1970s, interest renewed in coal pyrolysis, but in more recent times interest has again declined along with petroleum prices (Khan and Kurata, 1985).

Pyrolysis kinetics are reasonably well understood and have been modeled extensively (Solomon et al., 1993). Both yield and liquid fuel properties depend on pyrolysis conditions. Pyrolysis under mild temperatures $\left(500^{\circ} \mathrm{C}\right.$ to $700^{\circ} \mathrm{C}\left[930^{\circ} \mathrm{F}\right.$ to $\left.1290^{\circ} \mathrm{F}\right]$ ) and pressures (up to $50 \mathrm{psig}$ ) with rapid heat-up can produce high liquid yields without adding hydrogen. However, a significant part of the feed coal remains as char with market value comparable to or somewhat less than that of the feed coal. Coal pyrolysis offers some promise of lower liquid costs if the char can be upgraded to higher-value specialty products, such as form coke, smokeless fuel, activated carbon, or electrode carbon, or if the liquid yield can be significantly increased by using low-cost reactants (steam and carbon dioxide) or catalysts. Pyrolysis liquids have a low hydrogen-to-carbon ratio, generally less than one, in contrast to petroleum tars and bitumens (around 1.4) and high-quality petroleum products (approximately 2.0). They also contain substantial amounts of oxygen, compared to tars, and thus require more extensive hydrogen addition to produce specification fuels. Their tendency to polymerize on standing can cause operational problems, which also must be addressed.

Little heat is required to produce pyrolysis liquids from coal, however, and production as a side stream to coal gasification or fluidized-bed combustion is efficient. Pyrolysis reactors generally operate at modest pressures and temperatures compared to other coal conversion systems and offer high throughput. Both of these features lead to low capital cost. The cost of pyrolysis liquids could thus be low and might be competitive with bitumen or for integration with oil refinery hydroconversion operations where their solubility characteristics could improve 
the operability of hydrocarbon units. They could also be combined with direct coal liquefaction. When made from low-sulfur coal, pyrolysis liquids have limited potential as a substitute without refining for petroleum fuel oil, and an ongoing CCT program (ENCOAL Mild Coal Gasification project) is aimed at this market. Pyrolysis liquids have traditionally been a source of coal tar chemicals, and the DOE Mild Gasification program is aimed, in part, at this market (see below).

The budget for the DOE Advanced Clean Fuels Program within the FE coal R\&D activity underwent a 30 percent reduction between FY 1993 and FY 1994, and a further 45 percent reduction is proposed for FY 1995 (see Table 2-1). These budget decisions reflect a diminished commitment to the use of coal for production of clean liquid fuels by either indirect or direct liquefaction. Of particular note is the proposed reduction of 84 percent in FY 1995 funding for Advanced Research and Environmental Technology; programs in this area are expected to lead to improvements in efficiency and cost reductions for liquid fuel production (see Chapter 9).

\section{COAL REFINERIES AND COPRODUCT SYSTEMS}

A coal refinery or coproduct system is defined as "a system consisting of one or more individual processes integrated in such a way as to allow coal to be processed into two or more products supplying at least two different markets" (DOE, 1991). The concept resulted from the realization that coal must be processed in nontraditional ways to meet the needs of potential expanded markets. A key feature of the coal refinery concept is the production of more than one product form, for example, steam and electricity or fuel gas and electricity. The concept can be generalized to include cogeneration of steam and electricity, production of fuel gas for both industrial heat and electricity generation, production of syngas for manufacture of chemicals and/or fuels, capture and use of pyrolysis tars for chemicals and fuels manufacture, and production of specialty cokes.

\section{Cogeneration}

Cogeneration was initially practiced in energy-intensive industrial plants to meet internal needs for steam and electricity. Steam and electricity coproduct systems are now a major commercial activity. With few exceptions cogeneration facilities are designed to use natural gas because of the lower investment compared to a plant that uses coal. As natural gas prices rise to a level that renders the higher investment in coal facilities economically advantageous, advanced cogeneration systems, where the first step is gasification, could also supply coal liquids, fuel gas, and syngas made from coal. Currently, there appears to be ample opportunity for a variety of coproducts produced by the primary coal gasification process. Steam and electricity would continue to be major products.

It seems reasonable to expect that the time for introduction of cogeneration systems based on coal would approximately correspond to the time when the projected cost and/or availability of natural gas would justify investment in new coal-based, power-generating facilities, perhaps during the mid-term period (2006-2020). This time might well arrive before manufacture of 
synthetic natural gas is required to meet domestic demand. The large world resources of petroleum and bitumen, combined with low prices, are expected to defer manufacture of liquid transportation fuels from coal until the price range is $\$ 25$ to $\$ 30 / \mathrm{bbl}$, although security considerations could call for an earlier date. The first major opportunity for coproducts would then arise from the predicted mid-term need for new high-performance coal-based, power generation systems. These high-performance systems will probably involve coal gasification offering the possibility of coproducts from the gasifier (syngas, fuel gas, and pyrolysis tar). The production of coproducts, in conjunction with SNG manufacture, was of major commercial and $\mathrm{DOE}^{7}$ interest until the 1980s, when low oil and gas prices and ample supplies eliminated the near-term economic incentive for synthetic fuels processes. The expected growth in coal-based power generation appears to offer a more robust opportunity for fuel and chemical coproducts than the traditional single product or dedicated plant approach.

The business environment and regulatory changes that have encouraged cogeneration could provide a framework for extension to the use of coal as a source of energy and a resulting greater variety of coproduct streams. Recent industrial concerns regarding efficient production of major products and conservation of capital are resulting in steam and power being supplied by external companies that build and operate facilities for supply of steam and electricity to both local manufacturing plants and utilities. In some cases these companies are subsidiaries of a utility. Such companies might supply fuel gas and syngas to chemical and petrochemical companies. Nonetheless, the complexity of the potential business relationships and the need for a flexible approach should not be underestimated.

With today's emphasis on increased generation efficiency and the availability of high-performance gas turbines and fuel cells, an incentive for development of high-efficiency gasification systems specifically designed to provide fuel for power generation has been established. As discussed earlier, these systems can differ from systems optimized to produce highly purified synthesis gas for conversion to chemicals and clean fuels in that dilution by methane and nitrogen is acceptable; a higher level of impurities can also be tolerated.

\section{Indirect Liquefaction}

DOE-sponsored design and systems studies by the Mitre Corporation and Bechtel (Gray, 1994; Tam et al., 1993) have provided information on cost for both present-day stand-alone indirect liquefaction plants and coproduction of coal liquids with gasification-based electrical power generation. ${ }^{8}$ For the stand-alone F-T synthesis, the Mitre study found an equivalent crude price of $\$ 35 / \mathrm{bbl}$. Coproduction with electricity reduced the equivalent crude cost by $\$ 5$ to $\$ 6 / \mathrm{bbl}$ to approximately $\$ 30 / \mathrm{bbl}$. The savings for coproduction were attributed to a combination of better heat integration and the economies involved in once-through operation.

${ }^{7}$ Prior to the formation of DOE in 1977 programs were conducted under the auspices of the Energy Research and Development Administration.

${ }^{8}$ See Chapter 2 and the Glossary for discussion of financing options. 
The study by Bechtel estimated a difference in equivalent crude cost of coal liquids produced by stand-alone and coproduction methods of approximately $\$ 7 / \mathrm{bbl}$. For coproduction, the gasoline boiling range fraction was sent to the turbines, thus reducing total liquid production but also avoiding the costs of upgrading the low-octane-number naphtha produced by this process. While the required selling price was similar to that for the Mitre study, the assumed refined product values were higher, with a larger assumed premium for the diesel fuel. This assumption, together with other cost differences, makes comparison of the two studies difficult. The Bechtel study estimates an equivalent crude price for coproduction of somewhat less than $\$ 25 / \mathrm{bbl}$. The cost estimates from the Bechtel and Mitre studies differ significantly from those found in a previous National Research Council study (NRC, 1990), where the estimated equivalent crude price was greater than $\$ 40 / \mathrm{bbl}$ for the stand-alone plant. The difference results from a combination of the inclusion of inflation in the DOE-sponsored studies, higher product values, improved gasification technology, and use of the slurry reactor.

World oil prices in 2010 are projected to be in the range of $\$ 18$ to $\$ 34 / \mathrm{bbl}$ (EIA, 1994). For the EIA reference case, the projected oil price in 2010 is $\$ 28 / \mathrm{bbl}$, indicating that, on the basis of the estimated costs discussed above, indirect liquefaction could be of commercial interest within the mid-term timeframe (2005-2020). However, it is important to note that the estimated costs from the Mitre and Bechtel studies are for the " $n$ th" plant and are below pioneer plant costs. As in the case of advanced power generation technologies, early market entry would likely require some federal cost sharing (see Chapter 8 ).

\section{Direct Liquefaction}

Coproduction of coal liquids and electric power based on IGCC systems offers additional opportunities for cost reduction in the production of hydrogen, which could be used for direct liquefaction. No estimates of the magnitude of possible benefits are available for direct liquefaction; however, they would probably be somewhat less than those predicted for the F-T process because of lower synthesis gas consumption.

\section{Current Programs}

The U.S. Congress, in EPACT, directed DOE to examine the potential of coal refineries, evaluate their potential for meeting new markets, outline R\&D needs for potential commercialization, and prepare a report on the subject for congressional consideration (see Appendix A). DOE activities related to this directive have included continuation of the program sponsored by DOE's Morgantown Energy Technology Center aimed at commercialization of the mild gasification process, which is based on pyrolysis and is directed toward producing specialty cokes and tars for production of chemicals. No further funding for the program has been requested for FY 1995. In addition, the ENCOAL mild coal gasification project is being funded by DOE on a 50/50 cost-share basis with ENCOAL Corporation under Round III of the CCT program. The two year operational test period began in July 1992, and solid process-derived fuel 
and coal-derived liquids have been produced. DOE has also issued the mandated report to Congress (DOE, 1991).

DOE coal R\&D funding for systems for coproducts is divided into two categories: the mild gasification program and conceptual studies of coproduction of electricity and coal liquids. The former activity at the Illinois Mild Gasification Facility is cost shared with Kerr/McGee. It received \$1.5 million in FY 1993 and \$3.9 million in FY 1994; no funding was requested for FY 1995. A similar process is addressed in the ENCOAL CCT project, thereby reducing the incentive for major continuation of funding under the coal R\&D program. A conceptual study of electricity and coal liquids production-as proposed in the FY 1995 congressional budget request-could extend the existing preliminary studies. In FY 1995, \$0.6 million was requested for this study; there was no funding for this activity in FY 1993 and FY 1994.

\section{FINDINGS}

\section{Coal Gasification Technology}

1. Technology for the manufacture of clean gas is unique to coal-based systems; technology development is not addressed in DOE Fossil Energy programs other than those relating to coal (FE coal R\&D and CCT):

2. The expected major future use of coal gasification in power generation has stimulated industrial R\&D for gasification systems tailored to high-efficiency power generation requirements. Seven systems are scheduled for demonstration in the CCT program. However, further improvements in gasifier performance are required to achieve DOE's 45 percent efficiency goal for second-generation IGCC systems.

3. Use of coal gasification for supply of clean gaseous and liquid fuels, in addition to uses for power generation, provides an incentive to develop improved processes for this set of interacting needs. Fluidized-bed systems, with possible use of catalysts, offer an attractive method for providing the entire array of products from coal because of their temperature characteristics and compatibility with hot gas cleanup systems.

4. There are systems integration and research opportunities for further improvement in combined gasification/gas cleanup efficiency.

5. The air-blown fixed-bed gasifier scheduled for development at the DOE Gasification Product Improvement Facility may be competitive for use in a hot gas cleanup combined-cycle power generation system. If cold gas cleanup is used, the overall advantage over current commercial systems is not clear.

6. Despite opportunities for technology improvement, the proposed FY 1995 budget indicates reductions in funding for gasifier development, systems studies, and research. 


\section{Gaseous Products}

1. Manufacture of low- and medium-Btu gas is expected to play a major role in high-efficiency power generation systems, as a source of syngas and hydrogen for manufacture of coal-based liquid fuels, and for production of industrial chemicals.

2. Improvements in gasification efficiency and reductions in capital cost offer major R\&D opportunities.

3. While domestic natural gas is currently favored as fuel and as a source of hydrogen and synthesis gas, projected increases in price and decreased availability will increasingly favor use of coal-based gases. Displacement of natural gas by coal-based low- and medium-Btu gas can extend the supply of low-cost natural gas for domestic and commercial consumers and postpone the need for synthetic natural gas facilities.

4. Minimum $\mathrm{CO}_{2}$ production, as well as cost, will be important factors in the choice of processes to manufacture gaseous products from coall.

5. Efficient separation of gaseous products and gas cleanup processes offer opportunities for improvement.

\section{Liquid Fuels from Coal}

1. Advances in coal gasification and liquefaction technology have reduced estimated costs to approximately $\$ 33 / \mathrm{bbl}$ equivalent crude oil cost for mature (i.e., not pioneer) single-product plants using direct liquefaction with Illinois No. 6 coal.

2. Experience with sustained R\&D indicates that DOE's goal of $\$ 25 / \mathrm{bbl}$ (1991 dollars) for coal-based liquids may be attainable with continued research and systems studies.

3. Industrial programs have been drastically reduced.

4. The DOE budget for FY 1995 proposes a clrastic reduction in liquefaction activities.

\section{Coal Refineries and Coproduct Systems}

1. The concept of coal refineries or coproduct systems, defined as the production of more than one commercial product from coal, offers opportunities for optimization and significant cost reduction of coal conversion systems relative to single-product plants.

2. Coproduction with electricity has the potential to reduce indirect coal liquefaction costs by $\$ 6 / \mathrm{bbl}$ or more, indicating that pioneer production of liquids may become economically attractive in the timeframe projected for widespread construction of advanced gasification power generation facilities.

3. Opportunities for coproducts could determine the choice of gasification technology. Systems studies are needed to identify the major research, development, and commercialization opportunities.

4. The first major opportunities for implementation of coal refineries will likely involve electric power as the major product. Indirect liquefaction could well be the first application of coproduction with electricity. 
5. The large reduction in FY 1995 funding for DOE coal R\&D programs relating to coproduct systems is caused by discontinuation of the mild gasification activity. DOE has proposed $\$ 0.6$ million for conceptual studies of coproduction of liquids and electricity.

\section{REFERENCES}

CRS Sirrine Engineers, Inc. 1994. Gasification Product Improvement Facility Status. Paper presented at the Contractors Conference, U.S. Department of Energy, Morgantown Energy Technology Center, Morgantown, West Virginia, June.

COGARN. 1987. Coal Gasification: Direct Applications and Syntheses of Chemicals and Fuels. U.S. Department of Energy Coal Gasification Research Needs (COGARN) Working Group, DOE/ER-0326. Washington, D.C.: DOE.

DOE. 1991. Report to Congress: Coal Refineries, A Definition and Example Concepts. U.S Department of Energy, Office of Fossil Energy, DOE/FE-0240P. Washington, D.C.: DOE.

DOE. 1993a. Clean Coal Technologies: Research, Development, and Demonstration Program Plan. U.S. Department of Energy, DOE/FE-0284. Washington, D.C.: DOE.

DOE. 1993b. Direct Coal Liquefaction Baseline Design and System Analysis: Final Report on Baseline and Improved Baseline, Executive Summary. Prepared for U.S. Department of Energy, Pittsburgh Energy Technology Center, under contract no. DEAC22 90 PC89857. Pittsburgh, Pennsylvania: DOE.

DOE. 1994a. FY 1995 Congressional Budget Request. U.S. Department of Energy, DOE/CR0023, Vol. 4. Washington, D.C.: DOE.

DOE. 1994b. Clean Coal Technology Demonstration Program: Program Update 1993. U.S. Department of Energy, DOE/FE-099P. Washington, D.C.: DOE.

EIA. 1994. Annual Energy Outlook 1994. Energy Information Administration, U.S. Department of Energy, DOE/EIA-0383(94). Washington, D.C.: DOE.

EPRI. 1984. Coproduction of Methanol and Electricity., AP-3749. Palo Alto, California: Electric Power Research Institute.

Gilbert/Commonwealth, Inc. 1994. Optimization of Gas Stream Cleanup in Three IGCC Systems. Prepared for U.S. Department of Energy under contract DE-AC01-88FE61660. Reading, Pennsylvania: Gilbert/Commonwealth, Inc. 
Gray, D. 1994. Coal Refineries: An Update. Prepared for Sandia National Laboratories by the Mitre Corporation under contract no. AF-7166. McLean, Virginia: The Mitre Corporation.

Kastens, M.L., L.I. Hirst, and C.C. Chaffee. 1949. Liquid fuels from coal. Industrial and Engineering Chemistry 41: 870-885.

Khan, M.R., and T.M. Kurata. 1985. The Feasibility of Mild Gasification of Coal: Research Needs. U.S. Department of Energy, Morgantown Energy Technology Center, Technical Note DOE/METC-85/4019. Washington, D.C.: DOE.

Lumpkin, R.E. 1988. Recent progress in the direct liquefaction of coal. Science 239: 873-877.

NRC. 1990. Fuels to Drive Our Future. Energy Engineering Board, National Research Council. Washington, D.C.: National Academy Press.

NRC. 1993. Advanced Exploratory Research Directions for Extraction and Processing of Oil - and Gas. Board on Chemical Sciences and Technology, National Research Council. Washington, D.C.: National Academy Press.

Oil and Gas Journal. 1994. Alternate fuels: China's. 92: 35.

Probstein, R.F., and R.E. Hicks. 1982. Synthetic Fuels. New York: McGraw-Hill.

Schindler, H.D. 1989. Coal Liquefaction: A Research and Development Needs Assessment. Prepared for the U.S. Department of Energy, Office of Energy Analysis, DOE/ER-0400. Washington, D.C.: DOE.

Solomon, P.R., T.H. Fletcher, and R.J. Pubmire. 1993. Progress in coal pyrolysis. Fuel 72(5):587-597.

Stiegel, G. 1994. Indirect Liquefaction. Paper presented to the Committee on Strategic Assessment of DOE's Coal Program, National Academy of Sciences, Washington, D.C., Jan. 14.

Tam, S.M. 1993. Indirect Coal Liquefaction via Fischer-Tropsch Technology for the Baseload IGCC Plant. Paper presented at the IEA Second International Conference on the Clean and Efficient Use of Coal and Lignite: Its Role in Energy, Environment and Life, Hong Kong, Nov. 30-Dec. 3.

Tam, S.S., D.C. Pollack, and J.M. Fox. 1993. The combination of once-through FischerTropsch with baseload IGCC technology. P. 306 in Alternate Energy '93 held April 2830, 1993 in Colorado Springs, Colorado. Arlington, Virginia: Council on Alternate Fuels. 
Table 6-1 Status of Gasification Processes

\begin{tabular}{|c|c|c|}
\hline Developer $^{2}$ & Status & $\begin{array}{l}\text { Gasifier Exit Temperature }{ }^{\circ} \mathrm{C} \\
\left({ }^{\circ} \mathrm{F}\right)\end{array}$ \\
\hline \multicolumn{3}{|l|}{ Entrained-Flow Processes } \\
\hline Texaco (U.S.), CCT & Commercial & $1260-1480(2300-2700)$ \\
\hline Shell (Europe/U.S.) & Commercial & $1370-1540(2500-2800)$ \\
\hline Destec (U.S.), CCT & Commercial & $1040(1900)$ \\
\hline Prenflo (Europe) & $\begin{array}{l}\text { Commercial/ } \\
\text { demonstration }\end{array}$ & $1370-1540(2500-2800)$ \\
\hline \multicolumn{3}{|l|}{ Koppers Totzek (Europe) } \\
\hline $\begin{array}{l}\text { ABB/Combustion Engineering } \\
\text { (Europe/U.S.), CCT }\end{array}$ & Development & $1040(1900)$ \\
\hline IGC (Japan) & Development & $1260(2300)$ \\
\hline HYCOL (Japan) & Development & $1480-1620(2700-2950)$ \\
\hline VEW (Germany) & Development & \\
\hline \multicolumn{3}{|l|}{ Fluidized-Bed Processes } \\
\hline KRW (Europe/U.S.), CCT & $\begin{array}{l}\text { Demonstration/ } \\
\text { development }\end{array}$ & $1010-1040(1850-1900)$ \\
\hline $\begin{array}{l}\text { High-Temperature Winkler/Lurgi } \\
\text { (Europe) }\end{array}$ & $\begin{array}{l}\text { Demonstration/ } \\
\text { development }\end{array}$ & $950(1750)$ \\
\hline Exxon Catalytic (U.S.) & $\begin{array}{l}\text { Development } \\
\text { (currently inactive) }\end{array}$ & $760(1400)$ \\
\hline Tampella/UGas (Finland/U.S.), CCT & Development & $980-1040(1800-1900)$ \\
\hline MCTI Pulse Combustor/Gasifier, CCT & $\begin{array}{l}\text { Demonstration/ } \\
\text { development }\end{array}$ & $1090-1260(2000-2300)$ \\
\hline \multicolumn{3}{|l|}{ Moving Fixed Bed Processes } \\
\hline Lurgi (dry ash) (Europe) & Commercial $^{b}$ & \\
\hline British Gas Lurgi (slagging), CCT & Demonstration & \\
\hline $\begin{array}{l}\text { British Gas Lurgi (high pressure, } \\
1,000 \mathrm{psi} \text { ) }\end{array}$ & Development & \\
\hline $\begin{array}{l}\text { DOE-Sirrine Advanced Moving Bed } \\
\text { (U.S.) }\end{array}$ & $\begin{array}{l}\text { Research/ } \\
\text { development }\end{array}$ & $850(1560)$ \\
\hline
\end{tabular}

${ }^{2} \mathrm{CCT}$ is technology demonstrated in DOE's Clean Coal Technology program (see Table 6-4).

'Over 100 units in operation.

Sources: COGARN (1987); DOE (1994b). 
Table 6-2 Effect of Gasifier Design on IGCC Efficiency

\begin{tabular}{|c|c|c|c|c|c|c|}
\hline Case Number & 1 & $1 a$ & 2 & $2 a$ & 3 & $3 a$ \\
\hline Gasifier $^{3}$ & $\begin{array}{c}\text { KRW } \\
\text { fluidized- } \\
\text { bed }\end{array}$ & $\begin{array}{c}\text { KRW } \\
\text { fluidized- } \\
\text { bed }\end{array}$ & $\begin{array}{c}\text { KRW } \\
\text { fluidized- } \\
\text { bed }\end{array}$ & $\begin{array}{c}\text { KRW } \\
\text { fluidized- } \\
\text { bed }\end{array}$ & $\begin{array}{c}\text { CE } \\
\text { entrained- } \\
\text { flow }\end{array}$ & $\begin{array}{c}\text { CE entrained- } \\
\text { flow }\end{array}$ \\
\hline Oxidant & $\begin{array}{c}\text { air- } \\
\text { blown }\end{array}$ & $\begin{array}{c}\text { air- } \\
\text { blown }\end{array}$ & $\begin{array}{c}\text { air- } \\
\text { blown }\end{array}$ & $\begin{array}{l}\text { oxygen- } \\
\text { blown }\end{array}$ & $\begin{array}{c}\text { air- } \\
\text { blown }\end{array}$ & $\begin{array}{l}\text { air- } \\
\text { blown }\end{array}$ \\
\hline Gas cleanup ${ }^{b}$ & $\begin{array}{l}\text { in situ } \\
\text { plus } \\
\text { cold gas }\end{array}$ & $\begin{array}{l}\text { in situ } \\
\text { plus } \\
\text { hot gas }\end{array}$ & hot gas & hot gas & cold gas & hot gas \\
\hline $\begin{array}{l}\text { Carbon-to-gas } \\
\text { efficiencyc }\end{array}$ & 81.3 & 86.4 & 85.9 & 84.6 & 79.0 & 84.5 \\
\hline $\begin{array}{l}\text { Coal-to-gas } \\
\text { efficiency }\end{array}$ & 80.5 & 85.5 & 81.8 & 80.5 & 77.4 & 82.8 \\
\hline $\begin{array}{l}\text { Carbon-to- } \\
\text { electricity } \\
\text { efficiency }^{c}\end{array}$ & 44.9 & 46.7 & 46.0 & 45.0 & 43.4 & 45.4 \\
\hline $\begin{array}{l}\text { Coal-to-electricity } \\
\text { efficiencyc }^{c}\end{array}$ & 44.5 & 46.2 & 43.8 & 42.8 & 42.5 & 44.5 \\
\hline
\end{tabular}

${ }^{a} \mathrm{KRW}$, Kellogg-Rust-Westinghouse; CE, Combustion Engineering.

'In situ (Cases 1 and 1a) refers to limestone addition to the KRW gasifier for sulfur removal. Cold gas cleanup is at $315^{\circ} \mathrm{C}\left(600^{\circ} \mathrm{F}\right)$ for the $\mathrm{KRW}$ system (Case 1) and $230^{\circ} \mathrm{C}\left(450^{\circ} \mathrm{F}\right)$ for the CE system (Case 3). Hot gas cleanup is at $565^{\circ} \mathrm{C}\left(1050^{\circ} \mathrm{F}\right)$ for all systems and assumes use of candle filters for particulate removal and the General Electric barium titanate system for sulfur removal.

'All efficiencies are given as percentages on a higher heating value basis (see Glossary). The carbon-to-gas efficiency refers to the production of cleaned fuel gas, excluding carbon losses. The coal-to-gas efficiency includes all losses. Carbon conversion efficiencies for the KRW system are 99.0 percent for the in situ sulfur removal (Cases 1 and 1a), 95.2 percent without in situ removal (Cases 2 and 2a), and 98.0 percent for the CE system (Cases 3 and $3 a$ ).

Source: Gilbert/Commonwealth, Inc. (1994). 
Table 6-3 Gasifier Systems Being Demonstrated for Power Generation Under the CCT Program

\begin{tabular}{|c|c|c|c|c|c|}
\hline $\begin{array}{l}\text { Gasification } \\
\text { Technology }\end{array}$ & Name, Location & $\begin{array}{l}\text { Oxygen or } \\
\text { Air-blown }\end{array}$ & $\begin{array}{l}\text { Hot or } \\
\text { Cold Gas } \\
\text { Cleanup }\end{array}$ & $\begin{array}{l}\text { Total Project } \\
\text { Cost }^{2} \text { (millions } \\
\text { of current } \$ \text { ) }\end{array}$ & $\begin{array}{l}\text { DOE Cost } \\
\text { Share }{ }^{b} \text { (millions } \\
\text { of current \$) }\end{array}$ \\
\hline \multirow[t]{3}{*}{ Entrained-flow } & $\begin{array}{l}\text { Texaco, Polk Power } \\
\text { Station, Tampa } \\
\text { Electric Co. }\end{array}$ & Oxygen & $\begin{array}{l}\text { Cold plus } \\
10 \text { percent } \\
\text { hot }\end{array}$ & 241.5 & 120.7 \\
\hline & $\begin{array}{l}\text { Destec, Wabash } \\
\text { River Station, PSI } \\
\text { Energy, Inc. }\end{array}$ & Oxygen & Cold & 396.0 & 198.0 \\
\hline & $\begin{array}{l}\text { ABB Combustion } \\
\text { Engineering, } \\
\text { Lakeside Station, } \\
\text { City Water, Light } \\
\text { and Power }\end{array}$ & Air & Hot & 270.7 & 129.4 \\
\hline \multirow[t]{3}{*}{ Fluidized-bed } & $\begin{array}{l}\text { KRW, Tracy Station, } \\
\text { Sierra Pacific Power } \\
\text { (Pinon Pine) }\end{array}$ & Air & Hot & 270.0 & 135.0 \\
\hline & $\begin{array}{l}\text { MCTI Pulse } \\
\text { Combustor, Caballo } \\
\text { Rojo Mine }\end{array}$ & Air & Hot & 37.3 & 18.7 \\
\hline & $\begin{array}{l}\text { Tampella U-Gas, } \\
\text { Toms Creek Mine, } \\
\text { Va. }\end{array}$ & Air & Hot & 196.6 & 95.0 \\
\hline $\begin{array}{l}\text { Moving } \\
\text { fixed-bed }\end{array}$ & $\begin{array}{l}\text { British Gas Lurgi, } \\
\text { slagging, Camden } \\
\text { IGCC, Duke Energy } \\
\text { Corp. }\end{array}$ & Oxygen & Cold & 780.0 & 195.0 \\
\hline
\end{tabular}

${ }^{2}$ Total value of projects is $\$ 2,192.1$ million.

'Total DOE cost share is $\$ 891.8$ million (40 percent).

Source: DOE (1994b). 
Table 6-4 DOE Budget for Surface Coal Gasification (thousands of current dollars)

\begin{tabular}{lccr}
\hline & FY 1993 & FY 1994 & $\begin{array}{r}\text { FY 1995 } \\
\text { (request) }\end{array}$ \\
\hline $\begin{array}{l}\text { Design and construction of advanced hybrid } \\
\text { gasification systems }\end{array}$ & $5,350^{\mathrm{a}}$ & 8,205 & 10,140 \\
$\begin{array}{l}\text { Systems analysis and small-scale experimentation } \\
\text { for syngas and hydrogen }\end{array}$ & 765 & 453 & 395 \\
$\begin{array}{l}\text { Modeling, advanced gasification concepts, and } \\
\text { catalytic gasification }\end{array}$ & 1,447 & 471 & 410 \\
\hline
\end{tabular}

anvolves industry participation with 20 percent cost share.

Source: DOE (1994a). 
Table 6-5 F-T Process Development and Commercial Activities

\begin{tabular}{|c|c|c|}
\hline Participants & F-T Process & Status \\
\hline Sasol & $\begin{array}{l}\text { Lurgi/Sasol Arge fixed-bed process; waxy } \\
\text { product from coal feed }\end{array}$ & $\begin{array}{l}\text { Commercial operation at Sasol I for } 40 \\
\text { years }\end{array}$ \\
\hline Sasol & $\begin{array}{l}\text { Sasol Synthol circulating fluid bed; light } \\
\text { olefins and olefinic naphtha from coal feed }\end{array}$ & Commercial operation \\
\hline Sasol & $\begin{array}{l}\text { Slurry-phase process using coal feed; } 30-44 \\
\text { percent paraffins, } 50-64 \text { percent olefins; } 7 \\
\text { percent oxygenates }\end{array}$ & $\begin{array}{l}\text { Commercialized in } 1993 \text { after } 10 \text {-year } \\
\text { development program. Plant capacity is } \\
2,500 \text { bbls/day. }\end{array}$ \\
\hline $\begin{array}{l}\text { Shell Oil } \\
\text { Company }\end{array}$ & $\begin{array}{l}\text { Shell middle distillate fixed-bed synthesis } \\
\text { using gas feed }\end{array}$ & $\begin{array}{l}\text { Bitulu plant in Malaysia became } \\
\text { operational in 1993; capacity is } 12,000 \\
\text { bbl/day. }\end{array}$ \\
\hline $\begin{array}{l}\text { Mobil R\&D } \\
\text { Corporation/DOE }\end{array}$ & $\begin{array}{l}\text { Slurry F-T reactor with gas feed using ZSM- } \\
5 \text { catalyst }\end{array}$ & Major development in late 1980 s \\
\hline Exxon & $\begin{array}{l}\text { Slurry hydrocarbon synthesis with gas feed } \\
\text { and product hydroisomerization }\end{array}$ & $\begin{array}{l}\text { Program completed in } 1993 \\
\text { demonstrated processes at scale of } 200 \\
\text { bbl/day; ready for large-scale } \\
\text { commercialization. }\end{array}$ \\
\hline Statoil & Gas to middle distillate slurry process & Pilot plant stage \\
\hline $\begin{array}{l}\text { DOE plus } \\
\text { industrial partners }\end{array}$ & Slurry-phase F-T technology using coal feed & $\begin{array}{l}\text { Demonstrated at LaPorte facility in } \\
1992\end{array}$ \\
\hline
\end{tabular}

${ }^{2}$ Air Products, Exxon, Shell, and Statoil. 


\section{Electric Power Generation}

A major part of the DOE effort in the Office of $\mathrm{FE}$ is directed toward development of coal-fired electric power generation systems. The DOE program sponsors coal technology development from basic research through engineering, proof-of-concept testing, and commercialscale demonstration. These efforts include $R \& D$ on components that are engineered and designed to operate in an integrated fashion in advanced power generation systems. For example, IGCC electric power systems include components such as advanced coal gasifiers, high-temperature gas cleanup systems, and advanced gas turbines.

This chapter focuses on the main coal-based electric power systems under development in DOE and industry programs-namely, pulverized coal-based systems, fluidized-bed combustion systems, and integrated gasification-based systems. Other concepts, including magnetohydrodynamics and direct coal-fired heat engines, also are discussed. In each case the main emphasis is on identifying technical issues, risks, and opportunities likely to influence future development activities by DOE and other organizations. Two key components of many of these systems-combustion turbines and emission control technologies-are then discussed separately. Complementing the R\&D directed toward improvements in coal-based electric power systems, the DOE has engaged in extensive technology demonstration through its CCT program (see chapters 2 and 8). Relevant CCT demonstration activities are also addressed in this chapter.

DOE's programs in coal-based power generation focus on advanced technologies that can enable utilities to meet future environmental requirements while containing electricity costs. Thus, advanced power systems must not only produce significantly lower emissions than current coal-fired plants but also must compete economically with other future options. Higher efficiencies in the new technologies will contribute not only to lower fuel costs but also to improved environmental performance for a given power output. DOE's research goals for advanced power systems performance and cost were shown earlier in Table 2-3. Later sections of this chapter include discussions and assessments of goals for individual power generation technologies. Budget data are taken from the FY 1994 and FY 1995 congressional budget requests (DOE, 1993b, 1994d). The committee's comments on DOE's overall strategic objectives for advanced power systems are provided in Chapter 10. 


\section{PULVERIZED COAL SYSTEMS}

\section{Background}

Pulverized coal-fired electric power generation involves reducing coal size to a powder and conveying it with combustion air into a boiler where it is burned. The heat released evaporates water flowing in tubes in the boiler walls to form high-pressure, high-temperature steam, which is used to drive a turbine connected to an electric generator. The steam is then condensed back to a liquid and returned to the boiler to repeat the cycle (called the Rankine cycle). A wide range of coals may be combusted in pulverized coal boilers; however, units designed to burn a variety of coals are more costly than units using a more uniform fuel. Coal cleaning is widely practiced, usually at the mine, to reduce the coal ash and sulfur content and to raise its heating value, thus providing a more uniform fuel supply (see Chapter 5). Pulverized coal combustion has been practiced for many decades, and there is an extensive literature on boiler and system designs.

\section{State of the Art}

The overall efficiency of a pulverized coal power generation cycle is affected by many factors, including the thermodynamic cycle design, steam conditions (temperature and pressure), coal grind, combustion air-to-fuel ratio, fuel mixing, air leakage into the system, cooling (condenser) water temperature, and parasitic energy loads for auxilary equipment such as grinding mills, pumps, fans, and environmental control systems. The net thermal efficiency (conversion of fuel energy to electricity leaving the plant) of U.S. coal-fired generating plants operating today averages 33 percent (EIA, 1993). However, newer state-of-the-art plants with full environmental controls have efficiencies of 38 to 42 percent, the higher values corresponding to new supercritical steam units operating in Europe. Supercritical steam units operate at much higher temperature and pressure conditions than subcritical steam units, thus achieving higher overall efficiency. U.S. experience with early supercritical units installed in the 1960 s and 1970 s was generally unfavorable because of lack of operator experience and reliability and maintenance problems. Most U.S. coal plants today employ subcritical steam conditions, which give lower efficiency (typically 36 to 37 percent). Some early supercritical units, however, are still operating satisfactorily. The most efficient supercritical steam unit operating in the United States is the Marshall 4 unit of Duke Power, which was installed in 1970 with a design efficiency of 40 percent and today operates at a 38 percent efficiency without a FGD (flue gas desulfurization) unit (Electric Light and Power, 1993). Typical capital costs of modern U.S. subcritical pulverized coal plants equipped with an FGD system range from about $\$ 1,100$ to $\$ 1,500 / \mathrm{kW}$, with typical electricity costs of about 40 to 55 mills $/ \mathrm{kWh}{ }^{1}$

\footnotetext{
'Personal communication from C. McGowin, Electric Power Research Institute, to E.S. Rubin, Vice Chair, Committee on Strategic Assessment of DOE's Coal Program, May 1994.
} 


\section{Current Programs}

The DOE program to improve pulverized coal-based power generation systems builds on several aspects of current pulverized coal power generation technology that are commercial or near-commercial, including:

- staged air and other combustion modification techniques for $\mathrm{NO}_{x}$ control;

- selective noncatalytic $\mathrm{NO}_{\mathrm{x}}$ reduction using ammonia or amines;

- advanced (supercritical) steam conditions to $590^{\circ} \mathrm{C}\left(1100^{\circ} \mathrm{F}\right), 31 \mathrm{MPa}(4,500 \mathrm{psia})$;

- combined power generation and space heating (hot water);

- combined power generation and process steam (cogeneration);

- coal-water slurry combustion with up to 70 percent coal by weight; and

air.

- expansion turbine electricity generation using steam, hot combustion gases, or heated

As shown in Table 7-1, there are three major components of the DOE RD\&D (research, development, and demonstration) program on pulverized coal-based power generation systems: the APC (advanced pulverized coal) systems activity incorporating the LEBS (low-emission boiler system) program and the coal-fired cogeneration program; the IFC (indirectly fired cycle) system activity comprising the externally fired combined-cycle (EFCC) and HIPPS (highperformance power system) programs; and the direct coal-fired heat engines systems activity, incorporating two distinct but related power generation systems-direct coal-fired gas turbines and direct coal-fired diesels. The major technology goals for these programs are summarized in Table 7-1. The FY 1994 budgets for these activities were \$9.1 million for advanced pulverized coal and $\$ 14.4$ million for IFCs.

\section{Advanced Pulverized Coal}

The LEBS program is focused on improvement in currently available pulverized coal systems through integration with advanced combustion and emissions control technology and state-of-the-art supercritical steam generators. Three power system design teams are currently engaged in cost-shared systems analyses and preliminary design studies. Current designs include use of boiler combustion modification and advanced flue gas treatment systems (e.g., combined $\mathrm{SO}_{2} / \mathrm{NO}_{\mathrm{x}}$ removal) to achieve cost-effective emissions control. Selection of final designs for further development is scheduled for early 1995, with engineering development and subsystem testing to be completed in 1996. Proof-of-concept facility construction and operation are scheduled to lead to commercial readiness during the year 2000 (Ruth, 1994).

The related APC coal-fired cogeneration program is aimed at combined electricity and process steam generation in plants of $100 \mathrm{MW}$ electric (MWe) or smaller (i.e., medium industrial and institutional markets). The program addresses constraints imposed on the use of coal in urban areas-including environmental constraints-and the market for process steam. 


\section{Indirectly Fired Cycle}

IFC systems are advanced coal-based combined-cycle systems intended to compete with oil and gas-fired generation using conventional generation technology familiar to the utility industry. The EFCC variant necessitates the development of an advanced high-temperature ceramic heat exchanger to transfer the heat from coal combustion to an air stream that is the working fluid for a gas turbine. Thus, the turbine is not directly exposed to corrosive and abrasive coal combustion products. The ceramic heat exchanger tubes will allow clean filtered air from the gas turbine compressor to be heated to the turbine inlet temperature, eliminating the need for complex fuel preparation from pulverized coal (LaHaye and Bary, 1994). EFCC will demonstrate the combined cycle including steam generation from the gas turbine and combustion exhaust gases, using current postcombustion emission controls (e.g., FGD plus fabric filter). Subsequent development of HIPPS will incorporate a new high-temperature advanced furnace-also requiring development-that integrates combustion, heat exchange, and emission controls. Although there is no consensus that DOE's goal for $\mathrm{NO}_{\mathrm{x}}$ emissions (Table 7-1) can be met by application of advanced state-of-the-art staged combustor technologies, some optimism has been expressed. ${ }^{2}$ A major incentive is to avoid the additional cost of flue gas treatment (e.g., selective catalytic reduction) to meet the emissions goal.

\section{Direct Coal-Fired Heat Engines}

DOE's direct coal-fired heat engines program is directed toward commercialization by the private sector of two types of coal-fired engines-a direct-fired gas turbine and a direct-fired diesel engine. The program is aimed at burning coal-water slurry fuels in a combustion turbine by using a sufficiently clean fuel or modifying the turbine. The program is intended to develop modified diesel engines to burn coal-water slurry fuels. Both programs were completed in 1993 and are not part of ongoing DOE activities.

\section{Technical Issues, Risks, and Opportunities}

Central station power generation technology using pulverized coal is commercially mature and widely implemented in industrialized countries around the world. The large base of existing capacity and expertise provides a strong incentive to seek environmental, efficiency, and cost improvements by enhancing pulverized coal technology.

DOE's program goals for the LEBS system offer thermal and environmental performance goals comparable to the capabilities of state-of-the-art pulverized coal technology today (see Chapter 3), while EFCC and HIPPS offer a potential for significantly higher efficiencies. However, numerous technical challenges must be overcome if the program's environmental and efficiency goals for EFCC and HIPPS are to be met simultaneously with the cost goals,

\footnotetext{
${ }^{2}$ Personal communication from Janos M. Beer, Massachusetts Institute of Technology, to John P. Longwell, Chair, Committee on the Strategic Assessment of the DOE's Coal Program, July 25, 1994.
} 
especially for the higher-efficiency systems. Some of the major technical challenges, well recognized by DOE, include development of key system components, notably a specialized ceramic heat exchanger for EFCC, a high-temperature advanced furnace for HIPPS, and reliable low-emission slagging combustor technology.

An example of the technical challenges facing DOE is illustrated by the heat exchanger requirements for the EFCC system. Experimental studies in the 1940s on open-cycle, indirectly fired gas turbines using metallic heat exchangers did not allow sufficiently high turbine inlet temperatures for economic power production (Orozco, 1993). The use of ceramic materials may permit higher operating temperatures and resulting system efficiencies, but significant materials technology development is still required to achieve the performance targets projected in Table 7-1. The exit air temperature from current ceramic heat exchangers is limited by materials constraints (see Chapter 9) to approximately $1100^{\circ} \mathrm{C}\left(2000{ }^{\circ} \mathrm{F}\right)$, significantly below the inlet temperatures of $1290^{\circ} \mathrm{C}\left(2350^{\circ} \mathrm{F}\right)$ for state-of-the-art turbines, or $1370{ }^{\circ} \mathrm{C}$ to $1425^{\circ} \mathrm{C}(2500$ ${ }^{\circ} \mathrm{F}$ to $2600^{\circ} \mathrm{F}$ ) for advanced turbines. If development of a high-temperature, high-pressure ceramic heat exchanger proves not to be feasible either technically or economically, a compromise solution may be considered where natural gas is used to reach a high turbine inlet temperature. In one scoping design study (Bannister et al., 1993) the heat supplied from natural gas was on the order of 30 to 40 percent of the heat supplied by coal for a ceramic heat exchanger limited to an operating temperature of $1100^{\circ} \mathrm{C}\left(2000^{\circ} \mathrm{F}\right)$ or less.

In addition to these specific technical challenges, the DOE program emphasizes a "unified approach," "synergies," and integration of components and subsystems to achieve target efficiencies and reduce the cost of the commercialized technology (DOE, 1993a). To achieve these opportunities, substantial development and demonstration of integrated systems still remains.

\section{Findings}

Pulverized coal combustion systems are an established and mature technology for power generation, with comparatively limited opportunity for: further performance enhancements based on a simple Rankine steam cycle relative to advanced combined-cycle systems. Thus, the market niche for the LEBS system is not clear. Environmental performance is comparable to state-ofthe-art commercial systems available today, and the efficiency of the LEBS system is comparable to today's supercritical steam units. Potentially lower costs through system integration, however, could be of interest for near-term power generation markets.

The indirectly fired combined-cycle systems have the potential for significantly higher efficiency. However, this higher efficiency depends on providing gas heated to $1260{ }^{\circ} \mathrm{C}$ to $1425^{\circ} \mathrm{C}\left(2300^{\circ} \mathrm{F}\right.$ to $\left.2600^{\circ} \mathrm{F}\right)$, while heat exchanger materials are currently limited to $1100^{\circ} \mathrm{C}$ $\left(2000^{\circ} \mathrm{F}\right)$. Increasing this temperature is a major materials challenge. The fallback strategy of depending on natural gas for increasing the gas temperature could provide an interim system. 


\section{FLUIDIZED-BED COMBUSTION}

\section{Background}

Fluidized-bed combustion (FBC) technology consists of forming a bed of finely sized ash, limestone (for sulfur removal), and coal particles in a furnace and forcing combustion air up through the mixture, causing it to become suspended or fluidized. The height of bed material suspended above the bottom of the furnace is a function of the velocity of the combustion air entering below the bed. Atmospheric "bubbling-bed" FBC technology has a fixed height of bed material and operates at or near atmospheric pressure in the furnace. In atmospheric circulating FBC technology, the combustion air enters below the bed at a velocity high enough to carry the bed material out of the top of the furnace, where it is caught in a high-temperature cyclone and recycled back into the furnace. This recycling activity improves combustion and reagent utilization. In all AFBC (atmospheric fluidized-bed combustion) designs, coal and limestone are continually fed into the furnace and spent bed material, consisting of ash, calcium sulfate, and unreacted or calcined limestone, is withdrawn at the rate required to maintain the proper amount of bed material for fluidization.

The amount of coal fed into the bed is approximately 2 to 3 percent of the total weight of the bed material. The fluidization of the bed and the relatively small amount of coal present in the bed at any one time cause good heat transfer throughout the bed material, and the resulting bed temperature is relatively low, about $800^{\circ} \mathrm{C}$ to $900^{\circ} \mathrm{C}\left(1470{ }^{\circ} \mathrm{F}\right.$ to $\left.1650^{\circ} \mathrm{F}\right)$. The fluidization and relatively low bed temperature enhance the capture of $\mathrm{SO}_{2}$ emitted during combustion and retard the formation of $\mathrm{NO}_{\mathrm{x}}$. The features of in-bed capture of $\mathrm{SO}_{2}$ and relatively low $\mathrm{NO}_{\mathrm{x}}$ emissions, plus the fluid bed's capacity to combust a range of different fuels, are the main attractions of FBC as a power generation technology. Under some operating conditions, AFBC units also may produce higher levels of organic compounds, some of which may be potential air toxics. Current studies also indicate that AFBC units emit higher levels of $\mathrm{N}_{2} \mathrm{O}-\mathrm{a}$ greenhouse gas-than other combustion systems (Takeshita, 1994).

AFBC technology has been in commercial use worldwide for well over 50 years, primarily in the petrochemical industry and in small industrial steam generators that are a tenth to a hundredth the size of commercial power plant generators. In the United States, development of AFBC technology began in 1965, when DOE contracted for development of a low-cost, industrial-sized AFBC unit. AFBC development in the U.S. power generation sector began in the early 1980s, with support from the private sector, including EPRI (Electric Power Research Institute), and DOE. A 20-MW bubbling bed AFBC unit was constructed and operated by the Tennessee Valley Authority and EPRI beginning in 1980 and concluded in 1987. During this same period, four AFBC demonstration projects ranging in size from 80 to $160 \mathrm{MW}$ were implemented as either retrofits or repowering of an existing unit. As a result of these demonstrations and similar installations abroad, AFBC technology became commercial by the end of the 1980s for industrial steam generation, cogeneration, and utility-scale applications.

The next generation of FBC technology operates at pressures typically 10 to 15 times higher than atmospheric pressure. Operation in this manner allows the pressurized gas stream from a pressurized fluidized-bed combustion (PFBC) unit to be cleaned and fed to a gas turbine. The exhaust gas from the turbine is then passed through a heat recovery boiler to produce steam. 
The steam from the PFBC unit and that from the heat recovery boiler are then fed to a steam turbine. This combined-cycle mode of operation significantly increases PFBC system efficiency over the AFBC systems. If the PFBC unit exhaust gas can be cleaned sufficiently without reducing its temperature (i.e., by using hot gas cleanup systems), additional cycle efficiency can be achieved.

Development of PFBC has been under way since 1969, when the British Coal Utilization Research Association began operating a PFBC test unit at Leatherhead, England. A significant portion of the test work conducted there over the next 15 years was supported by EPA, DOE, and the U.S. private sector. In the early 1980s a number of other PFBC test and pilot facilities were constructed in the United States and Europe. The United States, the United Kingdom, and the Federal Republic of Germany under the auspices of the International Energy Agency constructed an 85-MW thermal (MWt) PFBC unit that was placed in service in 1980. Early cooperation between the American Electric Power Service Company and ASEA STAL (now ASEA Brown Boveri, with its subsidiary ABB Carbon) led, in 1982, to the construction of a 15MWt PFBC component test facility now located in Finspong, Sweden (Miller et al., 1982).

\section{State of the Art}

AFBC technology has achieved commercial acceptance, while PFBC technology is currently undergoing commercial demonstration. As of mid-1993, 622 AFBC units (293 bubbling bed and 276 circulating bed) were operating worldwide, with an average steam capacity of $235,000 \mathrm{lb} / \mathrm{hr}$. About 43 percent of the steam capacity and 35 percent of the total number of units were sold in North America, mainly in the United States. EPRI has estimated that 75 percent of the U.S. capacity is circulating FBC technology. Independent power producers, rather than investor-owned utilities, have pushed the development of AFBC in the United States. The present generation of AFBC technologies has no difficulty meeting the current NSPS for steam electric power plants or industrial sources.

PFBC technology is in the early stages of commercialization. Four PFBC units of less than $80 \mathrm{MW}$, two in Sweden, one in Spain, and one in the United States, have been placed in operation in the past four years. A fifth 71-MW unit is in initial operation in Japan. The DOE CCT program is sponsoring an 80-MW circulating PFBC project expected to be in commercial operation in mid-1997 (DOE, 1994a).

In addition, the CCT program has selected a 95-MW second-generation PFBC project for funding. This advanced PFBC system will involve partial gasification of the coal, with the resulting fuel gas going to a topping combustor along with cleaned gases from a circulating unit that will receive char from the gasifier. Electricity is generated from the topping combustor and from a steam cycle coupled to the PFBC unit. An advanced system for hot gas cleanup will also be used in the demonstration. A fully integrated second-generation PFBC system is also scheduled to be tested at the 8-MWe level at the Power Systems Development Facility under construction in Wilsonville, Alabama, sponsored by DOE, Southern Company Services, and EPRI. This PFBC testing will evaluate the integration of all of the components in the PFBC system, with emphasis on the integration of hot gas cleanup ceramic filters and gas turbines (DOE, 1993a). 


\section{Current Programs}

DOE funding for AFBC technology development ended in FY 1992. The current PFBC program is aimed at developing second-generation systems for electric power generation with performance goals as summarized in Table 7-2. The FY 1994 Office of Fossil Energy budget for PFBC was $\$ 24.1$ million.

\section{Technical Issues, Risks, and Opportunities}

AFBC systems, either in the bubbling bed or circulating bed configuration, constitute a commercially mature technology, and DOE has contributed in a major way to its success. To further enhance its commercial application, manufacturers need to refine the technology to achieve lower capital costs compared with modern pulverized coal (PC) plants, improved environmental performance, and improved operating efficiency. However, the time period for competitive application of this technology in the U.S. electric power production sector is now and in the immediate future. The availability and cost of natural gas, along with competition from modern PC plants, will dictate whether AFBC continues to be a technology of choice for environmental compliance and new capacity additions by independent power producers. Because most new coal plants currently are being constructed outside the United States, the greatest opportunity for this technology is in developing countries.

PFBC technology is just beginning to be commercially demonstrated and offers significant design, performance, environmental compliance, and cost advantages over AFBC technologies. As noted earlier, a second generation of PFBC technology offering additional performance (efficiency) benefits is entering the pilot and demonstration phase. These systems employ a coal pyrolyzer to produce a fuel gas that is burned in the turbine topping cycle. Since only a portion of the coal is gasified, this design has the potential for higher efficiencies than IGCC systems, where all of the coal is gasified. Maude (1993) estimates that the efficiency advantage may be approximately four percentage points. Because PFBC operates at a higher pressure and increased efficiency compared with AFBC, the same power output can be achieved with a unit that requires less land area (i.e., smaller "footprint" of equipment). The steam flows for PFBC units also are compatible with steam turbines at existing power plants. Thus, the technology is especially attractive for repowering existing units at existing power plant sites, avoiding the need and difficulty of developing new sites. The higher cost of equipment operating at higher pressures and temperatures is partially offset by the reduced equipment size and higher efficiency. Efficiencies on the order of 39 to 42 percent can be achieved with newer PFBC designs, compared with 34 percent efficiency for AFBC. EPRI estimates the capital cost of a $340-\mathrm{MW}$ bubbling bed supercritical PFBC boiler (42 percent efficiency) at $\$ 1,318 / \mathrm{kW}$ (in 1992 dollars), with a total levelized cost of 37 mills $/ \mathrm{kWh}$ ( 80 percent capacity factor, eastern bituminous coal) (EPRI, 1993a).

Substantially higher efficiencies ( 45 to greater than 48 percent) are expected from secondgeneration PFBC systems. It is questionable whether the advanced PFBC systems can achieve DOE's goal of 20 to 25 percent reduction in electricity cost as well as capital cost reductions relative to current PC plants. In general, the higher degree of complexity of advanced systems 
makes it likely that capital costs will tend to increase rather than decrease, although the resultant efficiency gains will have a positive effect in lowering the cost of electricity. At present, however, there remains considerable uncertainty as to the future costs of advanced power systems.

One of the key performance and cost uncertainties for advanced PFBC systems is the development of hot gas cleanup technology. Reliable hot gas particulate cleanup plus advanced $\left(1370^{\circ} \mathrm{C}\left[2500^{\circ} \mathrm{F}\right]\right.$ or higher) turbine systems will be required for PFBC technology to achieve DOE's projected performance potential of more than 50 percent efficiency while meeting environmental compliance requirements. At the present time these technologies are under development. The status of hot gas cleanup technology and advanced turbine systems (ATS) is discussed later in this chapter.

Related issues concern the development of adequate $\mathrm{SO}_{2}$ and $\mathrm{NO}_{\mathrm{x}}$ controls and their associated costs. Current DOE flowsheets for advanced PFBC systems are beginning to incorporate the possible need for selective or nonselective catalytic reduction systems for $\mathrm{NO}_{x}$ control in addition to the combustion controls inherent in FBC systems. Added $\mathrm{NO}_{\mathrm{x}}$ controls would increase the base cost of the plant. Also of concern is the reagent requirement for sulfur removal and the resulting solid waste generation. As elaborated later in this chapter (see "Emission Control Technologies"), increasingly stringent requirements for $\mathrm{SO}_{2}$ removal are becoming more difficult or more costly to achieve with fluidized-bed systems, which also generate larger quantities of solid waste than new PC plants with FGD. An increase in solid waste generation is inconsistent with DOE's goals for advanced power systems, which seek sizeable reductions in solid waste. Thus, there is a need to demonstrate efficient environmental designs and to address potential by-product markets for spent reagent in order to reduce solid waste impacts.

\section{Findings}

AFBC systems are a mature commercial technology, and, as such, DOE is no longer pursuing additional R\&D on this technology. Significant performance improvements are expected for PFBC systems, which are now beginning to be commercialized. The DOE performance goals for the PFBC program appear to be reasonable for the first- and second-generation systems. The capital cost goals for all generations appear to be optimistic, especially as the number of components and complexity of the system are increased for the second-generation and improved second-generation systems. A major uncertainty still facing PFBC systems is the reliability and cost of hot gas particulate controls. Reduction of solid wastes, economical high $\mathrm{SO}_{2}$ removal efficiencies, and generation of supercritical steam in a fluidized bed are other issues to be addressed. 


\section{INTEGRATED GASIFICATION COMBINED-CYCLE SYSTEMS}

\section{Background}

Coal gasification is a method of producing a combustible gaseous fuel from almost any type of coal. The current status of gasification technology and opportunities for efficiency enhancement have been discussed in Chapter 6. Gasification is a key step for advanced conversion of coal to electricity using IGCC systems. An IGCC power plant is a gasification facility coupled to a gas-fired combined-cycle unit. Based on current environmental control capabilities, IGCC offers a coal-based power technology with low emissions, high thermal efficiency, and the potential for phased construction-that is, building simple-cycle natural-gasfired combustion turbines first, then converting to combined-cycle, and finally adding coal gasification as gas prices increase or gas availability deteriorates. Future advances in gasification-based power production are linked to increases in gas turbine firing temperature, hot gas cleanup of the fuel gas, coproduction of both chemicals and electricity, improved gasifier designs, and integration of gasification with advanced cycles and fuel cells.

\section{State of the Art}

Components of IGCC technology have been under development for some time, and several competing coal gasification processes now have successful commercial-scale operating records (see Chapter 6). These include the Texaco, Shell, and Destec (formerly Dow) entrainedflow processes and the Lurgi moving-bed process. Other gasification processes have been successfully tested at pilot scale and are ready for scale-up to commercial size, including the Prenflo entrained-flow, the British Gas/Lurgi moving-bed, and the KRW and the hightemperature Winkler fluidized-bed processes.

The IGCC concept was first successfully demonstrated at the 100-MW scale at Southern California Edison's Cool Water Station in Daggett from 1984 to 1989 using the Texaco entrained-flow coal gasification process. Destec is currently operating a 160-MW IGCC plant in Plaquemine, Louisiana, using a two-stage, entrained-flow coal gasification process. In the Netherlands, SEP (the joint authority for electricity production) has begun operation of a 250MW IGCC plant based on the Shell entrained-flow coal gasification process. Each of these plants employs gas turbines with firing temperatures of about $1100^{\circ} \mathrm{C}\left(2000^{\circ} \mathrm{F}\right)$.

Table 7-3 summarizes the performance and economics for a hypothetical 500-MW firstgeneration IGCC plant employing a state-of-the-art, oxygen-blown, entrained-flow gasification process to provide fuel gas to advanced combustion turbines. The IGCC plant is fueled with an eastern bituminous coal, is highly integrated, and employs cold gas cleanup. The cost for current systems is significantly higher than the DOE goals for advanced systems shown later in Table 7-4. 


\section{Technical Issues, Risks, and Opportunities}

First-generation IGCC plants have already demonstrated outstanding operability and environmental performance at commercial scale. The key issue for these technologies is the impact of high capital cost on economic competitiveness. Chapter 6 discussed technical issues and opportunities related to coal gasifiers. Reductions in the capital costs of IGCC systems can be accomplished through simplification and optimization of the process, economies of scale, and/or through thermal efficiency gains. Future improvements to the economics of IGCC, therefore, are linked mainly to development of advanced gas turbines with firing temperatures over $1370^{\circ} \mathrm{C}\left(2500^{\circ} \mathrm{F}\right)$ and secondarily to development of reliable hot gas cleanup schemes. Both of these subjects are discussed later in this chapter. As noted in Chapter 6, energy losses in gasification and gas cleanup amount to about 15 to 20 percent of the total coal energy input, resulting in a loss of 5 to 10 percentage points in power generation efficiency. Thus, improved gasifier designs with lower energy losses also can contribute to overall efficiency improvements. Current systems studies suggest that the integration of gasification with advanced cycles, such as the humidified air turbine, and compressed air storage with humidification, also has the potential to reduce capital costs and provide competitive intermediate-load capacity (EPRI, $1991 \mathrm{~b}, 1993 \mathrm{c}, \mathrm{d})$. The highest-efficiency system proposed by DOE and based on gasification is an integrated gasification advanced-cycle (IGAC) system based on a humidified gas turbine (DOE, 1993a).

\section{Current Programs}

DOE's program goals for IGCC systems are summarized in Table 7-4. The FY 1994 Fossil Energy coal program authorization for IGCC was $\$ 27.2$ million. The DOE CCT program also includes several gasification-based power projects, which represent the state of the art and encompass both entrained-flow and fluidized-bed gasification systems. Table 6-3 summarized the status of these CCT projects. The completion of the CCT programs in about five or six years will provide the data and experience for subsequent commercial IGCC plants to be employed beyond the year 2000. Table 7-5 summarizes the major European IGCC projects in progress. Except for the Buggenum project (Table 7-5), all the combustion turbines are $1300^{\circ} \mathrm{C}$ class $\left(2350^{\circ} \mathrm{F}\right)$. Other IGCC projects are also planned for Asia.

\section{Findings}

IGCC offers a coal-based power technology with low emissions, the potential for higher thermal efficiency, and the capability for phased construction. First-generation IGCC plants have already demonstrated outstanding operability and environmental performance at commercial scale. The key issue for these technologies is the high capital cost and its impact on economic competitiveness.

Gasification is an enabling technology that allows the use of very high efficiency energy conversion devices-such as high-temperature gas turbines and fuel cells-for power production 
in combined-cycle systems. Reductions in capital costs can be accomplished through process simplifications, economies of scale, and thermal efficiency improvements. With completion of the DOE CCT programs and the major European demonstration projects in the next five to six years, areas for continued improvements to the gasification technologies and IGCC process can be identified to reduce the capital cost and enhance the economic competitiveness.

\section{INTEGRATED GASIFICATION FUEL CELL SYSTEMS}

\section{Background}

Fuel cells are electrochemical energy conversion devices that convert the chemical energy in a fuel and oxidant directly to electricity without direct combustion. They can be thought of as "gas batteries" where the electrochemically active materials are gases that can be ducted to the electrodes from outside the battery case. The reaction products are also gases and can be removed similarly. A fuel cell can be "discharged" continuously to produce electricity so long as the reactants are supplied and the products removed.

The fuel cell has many of the same features as a battery. The power production takes place at a constant temperature; hence, it is not constrained to the theoretical upper limit for heat engines (known as the Carnot cycle efficiency). Thus, fuel cells potentially can be much more efficient than combustion-based systems. Environmentally, the electrochemical reactions do not involve direct combustion, so thermal $\mathrm{NO}_{\mathrm{x}}$ production is negligible. Reactants are consumed exactly in proportion to the electric energy output, so the efficiency remains high even when the level of power production is reduced.

In practice, fuel cell system efficiencies remain limited by energy losses and inefficiencies inherent in most engineered systems. Continued R\&D is aimed at reducing these losses to improve overall efficiency. An attraction of fuel cell systems is that natural gas or coal-derived fuel gas both make suitable fuels for running a fuel cell system. Interest in fuel cells as an energy conversion system stems primarily from the fact that they offer the highest efficiency and lowest emissions of any known fossil-fueled power generation technology.

\section{State of the Art}

Fuel cells first came to public attention in the 1960s because of their importance in the manned space program. Today, commercially available fuel cell systems are based on phosphoric acid fuel cell (PAFC) technology and are configured for small-scale commercial and residential cogeneration applications. These systems use natural gas or other light hydrocarbons as fuel. They typically yield 36 percent net electrical efficiency and over 70 percent total efficiency if all thermal energy is used (e.g., for space heating). This type of fuel cell operates at approximately $200^{\circ} \mathrm{C}\left(400^{\circ} \mathrm{F}\right)$, too low a temperature for the thermal energy to be efficiently converted to useful work in a bottoming cycle. ONSI Corporation has delivered nearly 60 of the 200-kW PAFC cogeneration systems. Plant reliability and availability based on experience to date have been outstanding. 
Molten carbonate fuel cells (MCFC) using a molten alkali-metal carbpmate electrolyte operate at approximately $650^{\circ} \mathrm{C}\left(1200{ }^{\circ} \mathrm{F}\right)$, a temperature where rejected heat can be used efficiently in a bottoming cycle and where conventional materials still can be used for the balance of plant equipment. This type of fuel cell power plant is just entering the demonstration phase of development. Power plants from several U.S. and Japanese manufacturers ranging in size from $200 \mathrm{~kW}$ to $2 \mathrm{MW}$ are planned to be in operation in 1995. These plants are expected to enter the utility market as 1- to 5-MW units, natural gas fueled, with electrical generation efficiency greater than 50 percent (without a bottoming cycle) by the year 2000. In larger sizes, with steam or gas bottoming cycles, efficiency will be 60 percent or higher when using natural gas fuel (EPRI, 1993b).

The solid oxide fuel cell (SOFC), of which the basic building block is an oxide-ion conducting ceramic electrolyte, operates at an even higher temperature $\left(980^{\circ} \mathrm{C}\left[1800^{\circ} \mathrm{F}\right]\right)$. The potential for future cost reduction makes SOFCs attractive. The most successful system to date is the Westinghouse tubular design that has been operated in units of up to $20 \mathrm{~kW}$ for over 6,000 hours. The key fabrication issue is the use of chemical vapor deposition to fabricate these tubular components, which is expensive. A great deal of current research is focusing on simpler planar systems that show promise for less expensive fabrication techniques. The largest planar unit under test at this time is $1 \mathrm{~kW}$. It is anticipated that the scale will be increased to $10 \mathrm{~kW}$ within one year.

Fuel cells integrate readily with coal gasifiers. Such IGFC sytems are potentially the most efficient and least polluting method to generate electricity from coal. Characteristics of the three types of fuel cells integrated with coal gasifiers are given in Table 7-6. EPRI (1993b) estimates that integrated gasification molten carbonate fuel cells based on current state-of-the-art entrainedflow gasification will have a full-load efficiency around 50 percent. Because of energy losses of about 15 to 20 percent inherent in gasification (see Chapter 6), major advances in gasification technology will be required to meet the DOE IGFC efficiency goal of 60 percent or greater. The total capital requirement is approximately $\$ 1,900 / \mathrm{kW}$, and the cost of electricity is not yet competitive with other gasification-based power systems. The capital cost must be reduced by approximately 20 percent to make the systems competitive. This is generally considered feasible, with technological advances already planned for the fuel cell and gas cleaning subsystems within the plant.

\section{Technical Issues, Risks, and Opportunities}

IGFC will not materialize for utility-scale electricity generation until the fuel cells are first used commercially as small-scale distributed generators on natural gas. This in turn requires demonstration that engineering development issues are resolved and that the fuel cells themselves have the reliability and durability necessary for utility service. Since demonstration projects are costly, there is the risk that commercial firms could fail because of insufficient funds to complete the necessary demonstrations of their technology.

Molten carbonate systems offer the most attractive near-term opportunities for utility applications. For the long term, there is some risk that the MCFC manufactured cost will not decrease to the levels needed for widespread use in distributed generation and in coal-based 
IGFC systems. Independent studies of MCFC manufacturing methods, however, show that stack costs similar to combustion turbines (i.e., $\$ 250 / \mathrm{kW}$ ) are possible in production quantities of 300 to $400 \mathrm{MW}$ per year (EPRI, 1992b). Manufacturing costs now are about 10 times higher-partly because manufacturing facilities are still about 100 times smaller. Studies indicate that the balance of plant costs will exceed the stack costs in commercial fuel cell power plants. A systematic market-entry program is the key to overcoming the high-cost, low-volume hurdle of new technologies.

For applications with coal, contamination of the fuel cell by trace coal constituents is the primary area of concern. Substances such as chlorides, sulfides, arsenic, alkali metals, zinc, cadmium, lead, and mercury vapors are capable of poisoning fuel cells and reducing their performance. At present, there is little information on the acceptable levels of these contaminants. High-temperature purification systems that can reduce some trace contaminants to very low levels are under development (Pigeaud, 1994).

\section{Current Programs}

DOE's program goals for IGFC systems are presented in Table 7-4. The FY 1994 budget authorization for fuel cells RD\&D-which is now in the natural gas program-was $\$ 51.8$ million. DOE is supporting technology and demonstrations of MCFC by two manufacturers at approximately $\$ 30$ million/year, with EPRI and GRI collaborating at approximately $\$ 5$ million/year each. One application is a 2-MW plant for the Santa Clara, California, municipal electric utility grid; the other is a $250-\mathrm{kW}$ pilot plant at Unocal's research center. Both demonstrations are expected to begin operation in the first half of 1995.

EPRI also has been sponsoring testing of a $20-\mathrm{kW}$ MCFC stack on a coal-gas slipstream at the 160-MW Destec IGCC plant in Plaquemine, Louisiana, since late 1993. To date, this test has shown no indication that coal-derived gas presents any difficulty in use. However, long-term data remain to be collected.

DOE is supporting SOFC R\&D at approximately $\$ 18$ million per year, with EPRI and GRI each contributing approximately $\$ 1$ million/year. For the tubular SOFC, the effort is focused on scale-up and demonstration. For the planar SOFC, the emphasis is on fundamental materials and manufacturing issues at a number of industrial, specialty research, and academic organizations. No prototype or commercial-scale plants are envisioned for three to four years for the planar SOFC. Many cost and manufacturing issues remain to be resolved in this time period.

While both the MCFC and SOFC systems ultimately will operate on gasified coal, at this time there are no commercial-scale or demonstration projects of coal-based IGFC.

\section{Findings}

The current U.S. fuel cell program is focused on the use of natural gas, although IGFC systems running on coal-derived fuel gas are envisioned by DOE as a logical follow-on. Such systems offer the highest efficiency and lowest emissions of coal-based technologies, but their 
cost currently is high. The initial demonstration of MCFC projects by two manufacturers is under way at the $250-\mathrm{kW}$ and $2-\mathrm{MW}$ scales using natural gas. However, it is not likely that these demonstrations will be capable of resolving all technical issues.

At a reasonable rate of growth in demand for fuel cells, manufacturing costs for MCFC stacks could drop an order of magnitude to the $\$ 250 / \mathrm{kW}$ range. A systematic market entry program is the key to overcoming the high-cost, low-volume hurdle. Therefore, planned DOE support of balance of plant cost reduction development is the logical next step in fuel cell technology development, since these costs are larger than the fuel cell stack costs.

Future development of coal-based IGFC systems will depend on the success of current gas-based technology and on the resolution of key technical issues, particularly the types and levels of contaminants in coal-derived fuel gas that must be controlled.

\section{MAGNETOHYDRODYNAMIC POWER GENERATION}

\section{Background}

MHD (Magnetohydrodynamic) power generation is a method for converting thermal energy directly to electric power. The MHD generator is based on the concept of using a flowing ionized gas or liquid metal heated by fossil and/or nuclear fuel as the moving conductor in an electric generator. By using this very high temperature (typically $2300^{\circ} \mathrm{C}\left[4170{ }^{\circ} \mathrm{F}\right]$ ) working fluid directly, the MHD generator serves as a topping cycle that achieves high overall efficiency ( 60 percent or more) when combined with additional power generation from a steam cycle fueled by the hot exhaust gas.

The simplest MHD generator is based on a linear geometry-the hot combustion gas flows through a linear duct or channel. A magnetic field provided by high-strength electromagnets at right angles to the gas flow induces an electric field at right angles to both the gas flow and magnetic fields. A "seed" material such as sodium or potassium is added to the combustion gas to improve its electrical conductivity. If electrodes are then placed on either side of the channel and connected through an external electrical load or resistance, current will flow through the gas, electrodes, and external load, providing power. In addition to MHD systems based on the flow of high-temperature seeded combustion gases, other proposed schemes for MHD power generation employ flows of liquid metals, combinations of liquid metals with gas bubbles, and alkali-seeded noble gases (or pure nitrogen or hydrogen) that ionize at much lower temperatures than do combustion gases (Angrist, 1976).

\section{State of the Art}

Most of the development work on MHD power generation has been on open-cycle combustion gas systems. These projects received significant funding in the United States (from DOE) and in the former U.S.S.R. Both projects have now been closed down. In the U.S.S.R. a 25-MW natural-gas-fired system (U-25) provided electricity to the Moscow power grid for several years. The DOE concentrated on smaller-scale coal-fired systems, which included tests 
of over 2,000 hours on the lower-temperature heat recovery systems. The proof-of-concept hightemperature combustion and MHD generator sections were run for only about 400 hours. While most of the test performance goals were reached, the long-term high-temperature component durability required for utility applications is still in question. A proposal to DOE's CCT program to scale up to a combined MHD-steam plant of about $75 \mathrm{MW}$ with an efficiency of approximately 31 percent was not selected for funding. Work on a tall-loop liquid metal MHD cycle has been concentrated in Israel, where test loops have been built to prove out the concept. These systems have the potential of 45 percent efficiency, but funding for further development is uncertain.

\section{Technical Issues, Risks, and Opportunities}

The open-cycle combustion gas systems as tested would extrapolate to a 500-MW coalfired MHD plant meeting the federal NSPS for $\mathrm{SO}_{2}$ and $\mathrm{NO}_{\mathrm{x}}$ with an efficiency of up to 45 percent (Lohrasbi et al., 1991). This efficiency potential would drop considerably for smaller power plants. A claimed potential efficiency of 60 percent could only be met with the development of a high-temperature heat exchanger to preheat the combustion air to over 1370 ${ }^{\circ} \mathrm{C}\left(2500^{\circ} \mathrm{F}\right)$, but little development work has been done on this exchanger. Furthermore, economic operation would depend on low-cost seed recovery, but only preliminary work has been accomplished in this area. The durability of the high-temperature MHD channel has not yet been demonstrated, and an integrated plant has not operated at any scale. Relative to other advanced technologies now under development, MHD systems pose much greater technological challenges because of the aggressive thermal environment and system complexity. At the same time, the thermal efficiency advantage of MHD systems has been eroded by more recent developments in other coal-based systems employing advanced gas turbines, fuel cells, and gasifiers.

\section{Current Programs}

DOE funding of the MHD proof-of-concept facility ended in FY 1993. FY 1994 funding and that requested for FY 1995 are only for site restoration, and no large-scale follow-on work is planned.

\section{Findings}

While a number of important technical goals were met by the DOE MHD program, significant issues were left unresolved, notably operational reliability. No U.S. funding is planned to resolve these remaining issues, since other advanced power systems now offer comparable or superior performance with higher reliability, lower projected cost, lower emissions, and a much lower level of technical risk. 


\section{COMBUSTION TURBINES}

\section{Background}

The combustion turbine is the key power generation component in most advanced coalbased systems. The turbine system consists of a compressor to take combustion air from atmospheric pressure to a pressure of 8 to 16 atmospheres; a combustor burning a fossil fuel (natural gas, light refined petroleum fractions, or coal-derived fuel gas) to produce hot combustion gases; and an expansion turbine to extract work as the high-temperature, highpressure gas is reduced to ambient conditions. This system is referred to as the Brayton cycle. About two-thirds of the shaft work of the expansion turbine drives the compressor, and the remainder drives a generator to produce electricity. The net power output depends strongly on the turbine inlet temperature, which is limited primarily by materials considerations. Combustion turbines can be designed to burn any of the above-mentioned fuels (provided they are adequately free of contaminants) and to switch from one fuel to another in service.

Two types of combustion turbines are uised for electric power generation, namely, heavyframe and aeroderivative turbines, the latter derived from jet engine technology. Historically, major evolutionary improvements in aircraft jet engine technology have been adapted to heavyframe utility combustion turbines. In addition, utilities have used aeroderivative combustion turbines for smaller-capacity generation applications. Thus, forecasting the evolution of combustion turbines for power generation is a relatively straightforward matter of assessing current jet airplane engine technology.

\section{State of the Art}

Current commercial gas turbine systems offered by U.S. and foreign manufacturers achieve firing temperatures up to $1300^{\circ} \mathrm{C}\left(2350^{\circ} \mathrm{F}\right)$, with unit sizes up to about $250 \mathrm{MW}$. Natural gas and light petroleum liquids are the fuels currently employed for power generation, typically for peak or intermediate loads. The simplest, lowest-cost-per-kilowatt, fossil power plant for peaking duty is the simple Brayton cycle combustion turbine described above. Both aeroderivative and heavy-frame turbines are used this way. Aeroderivative turbines are more efficient in simple-cycle operation because jet aircraft engines are intended to extract maximum energy from the hot combustion gases during the turboexpansion.

A combined-cycle combustion turbine plant, in which a Brayton cycle gas turbine is combined with a Rankine cycle steam generator using the waste heat in the exhaust from the turboexpander, is the most efficient system for a fossil power plant commercially available today. Because relatively little useful energy remains in the expander exhaust of an aeroderivative combustion turbine, the heavy-frame machine has the higher efficiency in combined-cycle operation. Table 7-7 compares the capacities and thermal-to-electric energy efficiency typical of $1300^{\circ} \mathrm{C}$-class $\left(2350^{\circ} \mathrm{F}\right.$-class), heavy-frame, and aeroderivative combustion turbines burning natural gas being sold now or expected for delivery in the mid-1990s.

If the feed gas has been cleaned to a level that will meet air quality standards, oxides of nitrogen $\left(\mathrm{NO}_{x}\right)$ are the only emission concern for combustion turbine power generation. Gas 
turbine manufacturers have developed dry (no water or steam injection) premixed lean-burn low$\mathrm{NO}_{x}$ combustors for commercially available gas turbines to achieve $\mathrm{NO}_{x}$ levels of 7 to $25 \mathrm{ppm}$ in the exhaust. As noted earlier (Chapter 3), such levels are required to comply wih various state and local regulations, which are far more stringent than the federal NSPS of $75 \mathrm{ppm}$ for gas turbines. Some of the first-generation dry low- $\mathrm{NO}_{x}$ systems, however, are not so effective if operating at low load. Steam injection is another approach used to lower $\mathrm{NO}_{x}$ and simultaneously augment power output by putting more mass through the turboexpander.

Continued evolution of gas turbines is projected with firing temperatures up to $1430^{\circ} \mathrm{C}$ $\left(2600{ }^{\circ} \mathrm{F}\right)$. These machines will require further cooling advancements, $\mathrm{NO}_{\mathrm{x}}$ reduction improvements, and probably ceramic nozzles and blades in the hottest sections of the hot gas path. The major combustion turbine manufacturers are forecasting commercial availability of such machines (using natural gas) in the 1998 to 2000 timeframe.

\section{Technical Issues, Risks, and Opportunities}

Ongoing and future technology improvements can further increase economic application of combustion turbines and broaden the attractiveness of coal utilization in advanced power systems. At this time, however, most of the technical issues and opportunities in gas turbine development remain focused on the use of natural gas. Cleaner fuels and combustion air to keep out corrosive agents, materials to resist corrosion at higher turbine operating temperatures, more sophisticated blade cooling methods (closed-circuit steam cooling, partial cooling of the last-stage blades), and designs for reduced maintenance all will increase reliability over current combustion turbine models and are expected to push combined-cycle efficiencies on natural gas to 53 percent (HHV) or higher by the end of the decade and to 57 percent no later than 2010.

Advancements in hot section cooling designs, construction materials, coatings for oxidation and corrosion resistance, and thermal barrier coatings (see Chapter 9) will be key to increasing combustion turbine firing temperatures and thus further increasing the efficiency of combustion turbines and associated coal-based power generation cycles. Single-crystal alloys-already used in aircraft engines-could advance last-stage turboexpander blading design and thus improve combined-cycle efficiency. A major uncertainty for coal-based applications is the level of fuel gas cleanup needed to protect such advanced turbine designs.

Other technical issues facing application of combustion turbines in advanced coal-based power generation include

- use of medium- and low-Btu fuel gas in combustors, and the effect of gas composition and variability on combustion efficiency and emissions;

- corrosion and/or deposition on turbine blades;

- integration of coal gasification with novel combustion turbine thermodynamic cycles;

and

- potential for catalytic combustion (low $\mathrm{NO}_{\mathrm{x}}$ ) technology using coal syngas.

Many of these issues are being addressed in the ongoing programs described below. For example, recently reported work at General Electric Company, sponsored by EPRI and DOE, 
has confirmed that the combustion of coal gas with heating values below $100 \mathrm{Btu} / \mathrm{scf}$ is stable with very low $\mathrm{CO}$ emissions if the volumetric ratio of hydrogen to carbon monoxide exceeds unity. $\mathrm{NO}_{\mathrm{x}}$ emissions are also significantly below current standards. Control of $\mathrm{NO}_{\mathrm{x}}$ emissions from advanced turbines achieving higher firing temperature (and thus producing higher thermal $\mathrm{NO}_{\mathrm{x}}$ in air-blown systems) will require further study to determine whether future standards can be met by combustion controls alone or if additional requirements for postcombustion controls will be required.

DOE programs have investigated the corrosion potential of alkali metals on gas turbine blades in both PFBC and IGCC systems. In lower-temperature systems below about $870{ }^{\circ} \mathrm{C}$ $\left(1600^{\circ} \mathrm{F}\right)$, little damage has been observed. At higher temperatures, there has been some experimental evidence that fine mineral matter components carried along in the gas phase interact with vapor-phase alkalis to form innocuous solids that do not attack the turbine blades. If the problem turns out to be more severe, blade coating has been identified as the most promising approach for current designs. For higher-temperature advanced turbines (e.g., 1430 $\left.{ }^{\circ} \mathrm{C}\left[2600^{\circ} \mathrm{F}\right]\right)$, requirements for contaminated removal from coal-derived fuel gas are not yet established.

Issues of system integration for coal-based power plants also remain to be addressed. At the present time, the concept of phased construction is widely viewed as a flexible strategy that can be a cost-effective way to transition the modest capital investment in a combustion turbine from peaking application to mid-load and eventually to baseload. However, there are significant technological and regulatory hurdles to overcome in such a conversion, which must be addressed. For example, a combustion turbine optimized for simple- or combined-cycle gas firing is not optimal for coal-based IGCC operation. Overall, converting to gasified coal lowers the net power plant efficiency by 5 to 10 percentage points-depending on gasifier and cleanup system design-relative to natural gas, primarily due to losses upstream of the turbine (Gilbert/Commonwealth, Inc., 1994).

Finally, turbine design modifications may be needed to take full advantage of integration issues that are unique to coal-based systems. For example, conceptually, integration of coal gasification with gas turbines that have been modified for operation on compressed humidified air from a storage reservoir have the potential to reduce gasification power plant costs by 20 percent. Another advantage to this cycle is that low-level waste heat energy can be reinjected into the cycle through the evaporation of hot water to humidify the high-pressure air. Expensive development efforts, however, will be required to modify existing aeroderivative turbines for this cycle. Systems studies are needed to identify the most promising options, as well as associated risks.

\section{Current Programs}

DOE's ATS program-housed in the natural gas program of the Office of Fossil Energy-is a major effort to develop and design high-efficiency combined-cycle combustion turbines. The FY 1994 authorization for this program was \$21.9 million; the FY 1995 DOE request has more than doubled to $\$ 44.9$ million. The research is aimed at potential barrier issues, focusing on two primary areas: higher firing temperatures, mainly from improved cooling 
concepts and materials, and high-efficiency cycles, aimed at steam cooling, interstage compression cooling, and chemical recuperation. The program aims to provide technology ready for commercial baseload application by 2000 that will be applicable to coal and biomass systems as well as natural gas. DOE is also involved in other cooperative programs with industry, notably the Collaborative Advanced Gas Turbine program involving DOE, EPRI, GRI, and turbine manufacturers.

Increases in the firing temperatures of advanced gas turbines will occur as a result of competitive pressures among manufacturers with a very significant acceleration resulting from the DOE ATS program. The availability of those machines will significantly improve IGCC plant efficiencies, as discussed earlier in this chapter. The higher-temperature turbines will also utilize higher pressure ratios and be significantly larger. As a result, single-train IGCC plants will have outputs of 350 to $400 \mathrm{MW}$, which will lower specific plant costs through improved economies of scale.

As noted above, the General Electric Company has successfully tested combustion in a General Electric model 7F combustion turbine of a simulated coal-based syngas diluted with $\mathrm{H}_{2} \mathrm{O}, \mathrm{CO}_{2}$, and/or $\mathrm{N}_{2}$ to $\mathrm{HHV}$ (higher heating values) as low as $100 \mathrm{Btu} / \mathrm{Scf}$. These heating values (which are nearly 10 times less than that of natural gas) are comparable to values from the low-Btu fuel gas produced by advanced air-blown coal gasifiers.

\section{Findings}

Combustion turbine technology will continue to advance rapidly, driven by aircraft technology improvements but also by power generation application needs. Continued combustion turbine technology improvements and advanced cycles development on natural gas also will benefit the economics of future coal-based systems such as IGCC, PFBC, and IFC designs.

With respect to coal-based applications, key issues and uncertainties include fuel gas cleanup requirements for advanced turbine designs and the design and integration of turbine systems that can optimally accommodate evolution from natural gas to coal gas firing. $\mathrm{NO}_{\mathrm{x}}$ emission control requirements and approaches for higher-temperature advanced turbines also remain to be resolved.

\section{EMISSION CONTROL TECHNOLOGIES}

\section{Background .}

The development of environmental control technologies for electric power generation has primarily focused on the control of air emissions resulting from the combustion of fossil fuels. For coal-fired steam-electric generation, the emphasis has been on the control of particulate matter, sulfur dioxide $\left(\mathrm{SO}_{2}\right)$, and nitrogen oxide $\left(\mathrm{NO}_{\bar{x}}\right)$ emissions-the three "criteria" air pollutants subject to federal NSPS (see Chapter 3 and Appendix D). 
Particulate emissions in coal-based systems arise primarily from coal ash entrained in the flue gas stream (flyash) and from chemical reagents added to control other pollutants, especially $\mathrm{SO}_{2}$. Control methods may employ inertial separation, wet scrubbing, electrostatic precipitation, or filtration to separate particles from the gas stream. The electrostatic precipitator (ESP) is the most widely used technology in conventional pulverized coal combustion systems. The particleladen flue gas passes through an ionizing field, which imparts an electric charge to the particles, allowing them to be collected on an oppositely charged surface. Alternately, a fabric filtration system may be employed to collect particles by passing the flue gas through a fabric filter (baghouse) collector, which operates much like a high-efficiency vacuum cleaner. Current IGCC systems remove particulates by condensing or quenching the raw fuel gas with water (wet scrubbing). First-generation PFBC designs often employ cyclone (inertial) separators in conjunction with an ESP or fabric filter. Advanced IGCC and PFBC systems employ solid (typically ceramic) barrier filters that operate at high temperature and pressure, in contrast to conventional low-temperature devices at atmospheric pressure.

Sulfur dioxide is a component of flue gas resulting from the oxidation of sulfur in the coal during combustion. Sulfur dioxide can be controlled by reducing the sulfur content of coal prior to combustion, by reacting the $\mathrm{SO}_{2}$ with a reagent (typically calcium-based) either during or after combustion, or by a combination of both approaches. Postcombustion removal of $\mathrm{SO}_{2}$ using wet or dry FGD (flue gas desulfurization) systems is the most common technology for conventional power plants. For PFBC systems, the $\mathrm{SO}_{2}$ reacts with a sorbent injected directly into the fluid bed. This approach is also being examined as an option for IGCC systems employing fluidized-bed gasifiers. Gasification-based power systems convert sulfur to hydrogen sulfide $\left(\mathrm{H}_{2} \mathrm{~S}\right)$ rather than $\mathrm{SO}_{2}$. Current IGCE systems employ cold gas cleanup to remove $\mathrm{H}_{2} \mathrm{~S}$ via commercial low-temperature absorption systems. Advanced IGCC systems are being designed to remove $\mathrm{H}_{2} \mathrm{~S}$ using an absorption-regeneration system at high temperatures to improve system efficiency. Any $\mathrm{H}_{2} \mathrm{~S}$ remaining in the gas stream is oxidized to produce $\mathrm{SO}_{2}$ emissions when the fuel gas is burned to generate electricity.

Nitrogen oxide emissions are formed from high-temperature reactions involving the oxygen and nitrogen present in coal and combustion air. Formation of $\mathrm{NO}_{x}$ can be reduced by various measures that control the temperature-time profile of combustion reactions. Postcombustion control of $\mathrm{NO}_{x}$ is typically accomplished by the injection of ammonia-based substances, with or without catalysts, that reduce $\mathrm{NO}_{\mathrm{x}}$ to nitrogen gas. In gasification-based systems, nitrogen in the fuel gas stream typically occurs as ammonia, which is converted to $\mathrm{NO}_{\mathrm{x}}$ upon combustion in the gas turbine. Cold gas cleanup systems remove most of the ammonia prior to combustion, thus lowering potential $\mathrm{NO}_{\mathrm{x}}$ emissions, while current hot gas systems do not. In the latter case, postcombustion controls could be required to meet applicable emissions standards.

Most current methods of air pollution control generate some type of solid waste that must be disposed of or reused. At a minimum, the wastes include the mineral matter (ash) originally found in the coal. Other wastes arise from technologies to control $\mathrm{SO}_{2}$ emissions. Technologies and processes do exist to replace or eliminate many of these wastes through reuse or by-product production, but most of these options are not economical in the United States at the present time. Hence, their use is not widespread. In the future, however, waste minimization is expected to become increasingly important in response to new economic and environmental pressures. 


\section{State of the Art}

Recent trends in particulate; $\mathrm{SO}_{2}$, and $\mathrm{NO}_{2}$ emission reductions achievable with current technology for pulverized coal-fired power plants were addressed in Chapter 3 (see Figure 3-2). Particiliate control technologies were the first to be developed, and their evolution has been undertaken primarily by the private sector with limited govermment. support. Current ESPs and fabric filters achieve emission levels of one-third to one-sixth NSPS levels at costs of about $\$ 50$ to $\$ 7.5 / \mathrm{kW}$ and about 2 to 4 mills/kWh in total electricity cost (Sloat et al.; 1993).

$\because$ FGD technologies came into use in the United States in the 1970s and were developed throughout the 1980 s with limited research and pilot plant efforts by EPA and DOE. Wet limestone systems, the most prevalent now in use, are being designed today for up to 95 percent annual average $\mathrm{SO}_{2}$ removal, with about 97 to 98 percent removal using organic acid additives, in contrast to 90 percent removal a decade ago. Wet scrubbers using-magnesium-enhanced lime systems are the most efficient FGD units now deployed, achieving over 98 percent $\mathrm{SO}_{2}$ removal (Makansi, 1993a). For the typical plant showr earlier in Figure 3-2a, this corresponds to an emission rate of $0.1 \mathrm{lb} \mathrm{SO}$ /million Btu, or one-sixth the NSPS level. On low-sulfur coals, lime spray dryer systems, originally deployed as a 70 percent removal technology, today are designed for over 90 percent $\mathrm{SO}_{2}$ removal in the United-States and over 95 -percent in Europe.

The cost of FGD systems also has decreased significantly. as a result of process improvements and design: simplifications over the past decade. "Typical: capital costs" for application with a new power plant now range from about $\$ 100$ to $\$ 200 / \mathrm{kW}$, with total levelized costs of about 5 to 10 mills/kWh (Keeth et al.; 1991). Cápital costs for retrofit systems are typically higher than those cited above. For example, the capital cost of most. FGD systems announced for Phase I compliance with the 1990 CAAAs (Clean Air Act amendments) range from $\$ 220$ to $\$ 260 / \mathrm{kW}$.(Colley et al:; 1993 ).

For $\mathrm{NO}_{2}$ control, advanced low- $\mathrm{NO}_{x}$ bumer designs and other combustion modifications now available or nearing commercialization are able to achieve emission reductions of 30 percent or more below the NSPS level for new PC-fired power plants (Kokkinis et al., 1992): Costs are relatively low, at roughly $\$ 7$ to $\$ 15 / \mathrm{kW}$. (EPRI, 1993b). Retrofit situations pose greater difficulties for coal plants due to the wide variety of boiler types and plaint vintage: $\mathrm{To}$ date; $\mathrm{NO}_{\mathrm{x}}$ reductions from existing coal-fired units have not yèt been widely undertaken or required to meet the ambient $\mathrm{NO}_{2}$ standard. :

. Postcombustion $\mathrm{NO}_{\mathrm{x}}$, removal systems employing selective catalytic reduction (SCR) technológy are now in widespread use on coal plants in Japàn and Germany; with about $30 \mathrm{GW}$ of installed capacity. (Scharer and. Haug, 1993). Current SCR technology achieves up to 90 percent $\mathrm{NO}_{x}$ removal in low- and medium-sulfur coal applications overseas (Makansi; -1993b): Such systems hiave not yet been deployed in the United States, -although demonstration of SCR with U.S. coals currently: is in progress as part of DOE's CCT program. A commercial order also has been placed for SCR on a.285-MW coal-fired plant operated by an independent power producer (Makansi, 1993b):

The cost of SCR remains high relative to combustion controls, although a decade of experience and the emergence of industry competition have lowered the cost significantly." Capital costs today are roughly $\$ 50$ to $\$ 80 / \mathrm{kW}$, with total levelized cösts of about 2 to 6 mills per kilowatt-hour for hot-side systems on new coal-fired plants (EPRI, 1991c). SCR costs are 
dominated by the cost of the catalyst and frequency of catalyst replacement. Substantial cost . reductions have been achieved in both areas in recent years. Retrofit costs for SCR can be significantly higher depending on the level of difficulty, the size and age of the plant, and other factors. For gas turbine systems, SCR already is required on some U.S. plants to meet local air quality standards. $\mathrm{NO}_{\mathrm{x}}$ emission levels of 9 -ppm or lẹss are being achieved (Makansi, 1993b). Gas turbine designers also are employing a variety of combustion-based control measures in efforts to avoid the need for tail-end SCR.

The DOE CCT program has resulted in significant joint federal and private sector funding for the further development and demonstration of advanced emission control technologies. As elaborated in Chapter 8, this program includes the commercial demonstration of 19 emission control systems, with five completed, 11 in operation, and three in design and construction. Table 7-8 shows the control levels projected to be achieved by the emission control systems in the CCT program and indicatés whether the technologies can be utilized for new facilities or as retrofits on an existing facility.

In addition to the emission control systems above, advanced systems employing hot gas cleanup and in-bed desulfurization are being developed. For PFBC systems, the current state of the art for sulfur removal employs a circulating FFBC designed to achieve $\mathrm{SO}_{2}$ removal efficiencies of 95 percent or more (DOE, 1994a). Scale-up and demonstration of this capability are planned under Round. $\mathrm{V}$ of the CCT program. The goal is to achieve $\mathrm{SO}_{2}$ reductions comparable to modern FGD systems at reagent stoichiometries low enough to permit economical operation with minimum solid waste. At the present time, relatively high reagent use often is required to achieve high $\mathrm{SO}_{2}$ removal efficiencies. The spent and unreacted sorbent roughly doubles the total solid waste for coal-fired plants.

Hot gas desulfurization systems that achieve over 99 percent sulfur removal from gasifier fuel gas streams also are scheduled for demonstrations in conjunction with several IGCC CCT projects. To date, hot gas $\left(480^{\circ} \mathrm{C}\right.$ to $700^{\circ} \mathrm{C}\left[900^{\circ} \mathrm{F}\right.$ to $\left.\left.1300{ }^{\circ} \mathrm{F}\right]\right)$ desulfurization systems employing regenerable metal oxides such as zinc ferrite and zinc titanate have not achieved the durability required for a cost-effective process. Continued work on improved sorbents and reactor designs is in progress (DOE, 1994b). System studies for IGCC systems using advanced fluidized-bed gasifiers also suggest that the optimal $\mathrm{SO}_{2}$ removal system may be a combination of hot gas desulfurization and in-bed desulfurization in the gasifier using limestone.

Hot gas particulate removal from PFBC and IGCC gas systems also is under development. These devices can be viewed as an integral component of the power generation system rather than as an environmental control technology, since they serve the critical function of removing particles and alkaline materials from the fuel gas to protect the gas turbine from erosion and corrosion. For current and advanced turbine designs, the cleanup requirements needed to protect the turbine from particle-induced damage exceed the current requirements for environmental protection. The most promising systems to date have employed barrier filters designed to achieve emissions of less than $2 \mathrm{ppm}$ by wèight of particles greater than 5 microns in diameter. The major problem, however, has been longevity. Current candle filter designs have operated no more than several hundred hours at the required temperatures $\left(760^{\circ} \mathrm{C}\right.$ to $870{ }^{\circ} \mathrm{C}$ $\left[1400^{\circ} \mathrm{F}\right.$ to $\left.1600{ }^{\circ} \mathrm{F}\right]$ ) before breaking, whereas lifetimes on the order of 16,000 hours are needed for economical PFBC systems (DOE, 1994c). Improved designs, as well as testing in the 
reducing gas environment of IGCC systems, are planned as part of the CCT demonstration projects.

With respect to solid waste emissions, many state-of-the-art air pollution control systems offer improved prospects for waste reduction through the production of salable by-products, especially with regard to sulfur emissions control. Modern FGD systems produce gypsum, which can be upgraded to commercial quality and sold (which is common practice in Europe and Japan). Several advanced flue gas cleanup systems being demonstrated in the CCT program produce by-product sulfur or sulfuric acid, as do the hot and cold gas cleanup systems employed with coal gasifiers. Only advanced PFBC systems increase rather than decrease the total solid wastes generated from coal use. In all cases the economic viability of by-product recovery systems depends on site-specific factors and markets. In the United States today, waste disposal in landfills is still more attractive for many electric utilities.

\section{Technical Issues, Risks, and Opportunities}

Existing control technologies for the criteria air pollutants $\left(\mathrm{SO}_{2}, \mathrm{NO}_{\mathrm{x}}\right.$, and particulates) associated with PC-fired power plants are capable of meeting current or anticipated emission reduction requirements in the near term (i.e., prior to 2005). The same is true of cold gas cleanup control technologies for gasification-based systems. Cost reduction and minimization of solid waste remain important goals to improve the viability of these coal-based systems. For the medium term (post-2005), additional performance improvements also may be required, especially for $\mathrm{NO}_{\mathrm{x}}$ controls.

Control technologies applicable to advanced combustion and gasification technologies need further development. In particular, hot gas cleanup systems for $\mathrm{SO}_{2}$ and particulate removal, which are critical to several of the advanced high-efficiency technologies-especially PFBC-have yet to achieve the performance, reliability, or durability needed for commercial applications. In IGCC systems, hot gas cleanup does not presently control nitrogen emissions (in the form of gaseous ammonia), which increases downstream costs and complexity for $\mathrm{NO}_{\mathrm{x}}$ controls in the gas turbine/heat recovery system. Research to address these issues is in progress.

With respect to solid waste minimization, one of the key needs is to improve the sorbent utilization for sulfur removal in advanced fluidized-bed combustors and gasifiers. Current PFBC systems produce the largest volume of solid waste per unit of sulfur removed. The presence of unreacted lime (as well as sulfides in the case of gasifiers) adds to the difficulty and cost of waste disposal. Pilot plant data for circulating PFBC designs show improved sorbent utilization relative to bubbling bed designs, but more work is needed to achieve commercially acceptable systems. More intensive research on reuse of spent sorbent also is needed if DOE's goal for solid waste reduction is to be achieved.

Control technologies for noncriteria pollutants also need to be addressed. To deal with the emerging issue of air toxics (see Chapter 3), trace substance emissions and fate must be characterized for current and advanced technologies. It is anticipated that existing high-efficiency particulate control technologies will be adequate to deal with most heavy metal emissions from coal combustion, but specific regulations have yet to be established. Similarly, the extent to which vapor-phase emissions such as mercury, chlorides, and selenium will have to be controlled 
is not yet clear; technologies to control these emissions may well be needed in the near future. Should that be the case, an additional risk of hot gas cleanup systems is their uncertain capability to control emissions of air toxics, since they presently do not remove vapor-phase species. Additional controls for air toxics may impose additional economic costs.

The ability of control technology to reduce or eliminate emissions of potential air toxics is currently under study by DOE, EPRI, and others. The most prevalent data are for conventional cold-side ESPs, which show high removal efficiencies for most heavy metals but much lower removal rates for volatile species such as mercury (Rubin et al., 1993). Wet FGD systems in conjunction with an upstream particulate collector appear to offer the greatest removal rates of volatile species and other potential air toxics such as chlorides. However, there is large uncertainty in the data, with relatively little information currently available for wet scrubbers operating in the United States. Experiments with carbon-based additives show an enhanced ability to remove mercury in some cases, particularly with high chloride coals. Research on novel control methods for air toxics is being pursued by EPRI, DOE, and others.

As noted in Chapter 3, a major concern for all coal-based technologies is the potential requirement to control carbon dioxide $\left(\mathrm{CO}_{2}\right)$ emissions. The most economical means is to improve the efficiency of energy conversion and utilization so that less $\mathrm{CO}_{2}$ is emitted per unit of useful energy delivered. For coal-fired power plants, average U.S. energy losses are about 2 percent in coal preparation, 67 percent in power generation, and 8 percent in transmission and distribution (EIA, 1993), yielding an overall efficiency of about 30 percent for fuel to delivered electricity. Within the limits of thermodynamic cycles, the greatest opportunity for energy efficiency improvements thus lies in the power generation process. As noted previously, the most efficient PC-fired plants commercially available today have efficiencies in the range of 38 to 42 percent. Thus, advanced technologies achieving 50 to 60 percent efficiency offer the potential to reduce $\mathrm{CO}_{2}$ emissions up to a third relative to current new plants.

The potential for $\mathrm{CO}_{2}$ capture and disposal also has received preliminary study (Ormerod et al., 1993; MIT, 1993; EPRI, 1991a). The consensus is that the technological means of scrubbing $\mathrm{CO}_{2}$ from flue gases already exists today but that the feasibility of $\mathrm{CO}_{2}$ disposal in deep wells, oceans, or other final storage sites remains a critical issue to be resolved. From a cost viewpoint, $\mathrm{CO}_{2}$ removal today is very expensive. Estimates for a 90 percent $\mathrm{CO}_{2}$ reduction suggest roughly a doubling of electricity generation costs and about a 35 percent energy penalty for removing and transporting $\mathrm{CO}_{2}$ to a hypothetical disposal site (NRC, 1992). Somewhat lower energy penalties are estimated for advanced combustion and gasification cycles. The development of viable $\mathrm{CO}_{2}$ removal and disposal processes remains a long-term challenge to control technology development.

\section{Current DOE Programs}

The Control Technology program in the Office of Fossil Energy is divided into four program components: Flue Gas Cleanup, Gas Stream Cleanup, Waste Management, and Advanced Research. As noted in Chapter 2, DOE has established incremental emission control goals for its Advanced Power Systems program (Table 2-3) that must be supported by the Control Technology program. The FY 1994 authorized budget for this activity was $\$ 13.25$ 
million for flue gas cleanup, $\$ 19.29$ million for gas stream cleanup, $\$ 2.41$ million for waste management, and $\$ 1.16$ million for advanced research.

As noted previously, commercial technology developed by the private sector with DOE participation already can achieve the DOE emission goals for 2000 and 2005 for conventional coal combustion systems. With the anticipated increase in demand for baseload generating capacity beyond 2005 and the expected tightening of future emission control requirements, the DOE program emphasis on developing improved control technologies for highly efficient, "superclean" power systems appears to be well placed.

The Flue Gas Cleanup program has a goal of reducing $\mathrm{SO}_{2}, \mathrm{NO}_{x}$, and particulate emissions to one-tenth current NSPS levels without high-volume waste generation (DOE, 1993a). Further goals are to control air toxics and $\mathrm{CO}_{2}$ emissions and to develop salable by-products from the control systems. Development of advanced FGD systems and combined $\mathrm{SO}_{2} / \mathrm{NO}_{\mathbf{x}}$ removal systems is also part of this program area. The other major component is the Gas Stream Cleanup program. It has a similar focus of removing contaminants from gasifier or combustor streams prior to their entry into advanced power systems such as the PFBC, IGCC, and IGFC systems. Activities focus on the development of high-temperature, pressurized contaminant control systems.

DOE also has a Waste Management program focused on waste products formed by advanced power generation technologies. The goal of that program is to ensure that solid waste from advanced fossil energy technologies is not a roadblock to commercialization of those technologies. More specifically, the objectives are to achieve a 50 percent utilization of solid waste from advanced fossil energy technologies and commercial markets by 2010 , to establish use for mine remediation of alkaline by-products such as are produced by fluidized-bed combustors and gasifiers with limestone added for sulfur removal, and to provide commercial acceptance of products manufactured from advanced pulverized coal by-products (DOE, 1993a). Many examples of successful waste product recycling, such as the use of flyash, exist. The best uses for the future are generally considered to be in construction, agriculture, mine reclamation, and soil stabilization. The present cost of these options and the enormous quantities of waste relative to by-product demand are the principal roadblocks to increased commercialization.

The final component of the Control Technologies Program is Advanced Research. The emphasis in this part of the program is on fundamental hot gas cleanup methods such as ceramic filter and membrane research.

\section{Findings}

Current commercial technologies for $\mathrm{SO}_{2}, \mathrm{NO}_{x}$, and particulate control for pulverized coal plants have improved substantially over the past decade and now can meet or exceed DOE's air pollutant emission targets for 2000 and 2005 . Cost reduction is the primary need and the main potential benefit of current CCT demonstration projects.

The most difficult near-term $R \& D$ challenges are in development of the hot gas particulate and sulfur cleanup systems to be employed with advanced power generation systems (IGCC, PFBC, IGFC). In particular, the technical problems of achieving reliable and sustained operation have yet to be overcome. Solutions to these problems are central to the achievement 
of cost-effective, high-efficiency power generation systems. Especially critical is the need for a high-temperature, high-pressure particulate removal system for advanced PFBC.

Other DOE programs are beginning or continuing to address the emerging issues of hazardous air pollutants (air toxics), greenhouse gas emissions (especially $\mathrm{CO}_{2}$ ), and solid waste minimization. All of these are important issues that will require increased R\&D attention in the future.

\section{REFERENCES}

Angrist, S.W. 1976. Direct Energy Conversion, 3rd Ed. Reading, Massachusetts: AddisonWesley.

Bannister, R.L., F.P. Bevc, W.F. Domeracki, and T.E. Lippert. 1993. Advanced coal-fired combined cycle power plant technology alternatives. Presented before the Coal-Fired Power Plant Upgrade Conference, Warsaw, Poland, June 15-17. Orlando, Florida: Westinghouse Electric Corporation, Power Generation Business Unit.

Colley, J.D., J.T. Waddell, and G.A. Hollinden. 1993. Development and Status of Flue Gas Desulfurization Technology Worldwide. Paper presented at the Eleventh International Conference on Power Stations, Association des Ingenieurs de l'Institut Montefiore, Sept., Liege, Belgium.

DOE. 1993a. Clean Coal Technologies: Research, Development, and Demonstration Program Plan. U.S. Department of Energy, DOE/FE-0284. Washington, D.C.: DOE.

DOE. 1993b. FY 1994 Congressional Budget Request. U.S. Department of Energy, DOE/CR0012, Vol. 4. Washington, D.C.: DOE.

DOE. 1994a. Clean Coal Technology Demonstration Program: Program Update 1993. U.S. Department of Energy, DOE/FE-0299P. Washington, D.C.: DOE.

DOE. 1994b. Summary of Hot Gas Desulfurization and Direct Sulfur Recovery Process Activities in the Fossil Energy Advanced Power Systems Program. U.S. Department of Energy, Office of Fossil Energy, Washington, D.C.: DOE.

DOE. 1994c. State-of-the-Technology: Hot Gas Particulate Filtration. U.S. Department of Energy. Washington, D.C.: DOE.

DOE. 1994d. FY 1995 Congressional Budget Request. U.S. Department of Energy, DOE/CR0023, Vol. 4. Washington, D.C.: DOE.

EIA. 1993. Annual Energy Review 1992. Energy Information Administration. U.S. Department of Energy, DOE/EIA-0384(92). Washington, D.C.: DOE. 
Electric Light and Power. 1993. Utilities advance power plant efficiency. 71(10): 9.

EPRI. 1983. Site Specific Assessment of a 150 MW Coal Gasification Fuel Cell Plant. Prepared by KTI Corporation for the Electric Power Research Institute, EM-3152. Palo Alto, California: EPRI.

EPRI. 1991a. Engineering and Economic Evaluation of $\mathrm{CO}_{2}$ Removal from Fossil Fuel-Fired Power Plants. Prepared by Fluor Daniel, Inc., for the Electric Power Research Institute, IE-7365, Vol. 1 and 2. Palo Alto, California: EPRI.

EPRI. 1991b. A Comparison of Humid Air Turbine (HAT) Cycle and Combined Cycle Power Plants. Prepared by Fluor Daniel, Inc. for the Electric Power Research Institute, IE7300. Palo Alto, California: EPRI.

EPRI. 1991c. Technical Feasibility and Cost of Selective Catalytic Reduction $\mathrm{NO}_{x}$ Control. Electric Power Research Institute, GS-7266, authored by C. Robie and P. Ireland. Palo Alto, California: EPRI.

EPRI. 1992a. Evaluation of Westinghouse Solid Oxide Fuel Cell Technology for Electric Utility Applications in Japan. Prepared by Westinghouse Electric Corporation for the Electric Power Research Institute, TR-100713. Palo Alto, California: EPRI.

EPRI. 1992b. Technical and Economic Assessment of Molten Carbonate Fuel Cell Manufacturing Costs. Prepared by Michael A. Cobb and Company for the Electric Power Research Institute, TR-101525. Palo Alto, California: EPRI.

EPRI. 1993a. TAG ${ }^{\mathrm{TM}}$ Technical Assessment Guide. EPRI TR-102275-V1R7. Vol. 1, Rev. 7, p. 8-76. Palo Alto, California: EPRI.

EPRI. 1993b. Applications of Carbonate Fuel Cells to Electric Power Systems. Prepared by Fluor Daniel, Inc., for the Electric Power Research Institute, TR-102931. Palo Alto, California: EPRI.

EPRI. 1993c. A Feasibility and Assessment Study for FT-4000 Humid Air Turbine. Prepared by Fluor Daniel, Inc. for the Electric Power Research Institute, TR-102156. Palo Alto, California: EPRI

EPRI. 1993d. Engineering and Economic Evaluation of Integrated Gasification Compressed Air Storage with Humidification. Prepared by Bechtel Group, Inc., for the Electric Power Research Institute, TR-103347. Palo Alto, California: EPRI.

Gilbert/Commonwealth, Inc. 1994. Optimization of Gas Stream Cleanup in Three IGCC Systems. Prepared for U.S. Department of Energy under contract DE-AC01-88FE61660. Reading, Pennsylvania: Gilbert/Commonwealth, Inc. 
Gilbert/Commonwealth, Inc. 1992. Ultra Supercritical Power Plants. Group discussion during meeting with ELSAMPROJEKT, EPRI, Sargetn \& Lundy, and Gilbert/Commonwealth, Inc., at Gilbert/Commonwealth, Reading, Pennsylvania, October 13.

Keeth, R.J., P.A. Ireland, and P.T. Radcliff. 1991. Economic evaluations of 28 FGD processes. Pp. 2-73-2-90 in Proceedings of the $1991 \mathrm{SO}_{2}$ Control Symposium, December 1991, Palo Alto, California, TR-101054. Palo Alto, California: Electric Power Research Institute.

Kokkinis, A., J.E. Cichanowicz, D. Eskinazi, J. Stallings, and G. Offen. 1992. $\mathrm{NO}_{x}$ controls for utility boiler: Highlights of the EPRI July 1992 workshop. Journal of the Air and Waste Management Association 42(11):1498-1505.

LaHaye, P.G., and M.R. Bary. 1994. Externally Fired Combustion Cycle (EFCC): A DOE Clean Coal V Project-Effective Means of Rejuvenation for Older Coal-Fired Stations. Paper presented at the ASME Turbo Expo '94, The Hague, Netherlands, June 13-16.

Lohrasbi, J., G. Ashby, and F. Walter. 1991. Economics of MHD retrofits and new plants. P. $\mathrm{x} 1.2 .1$ in Proceedings of the 29th Symposium on Engineering Aspects of Magnetohydrodynamics, New Orleans, Louisiana, June 18-20. Tullahoma, Tennessee: Symposia for Engineering Aspects of MHD, Inc.

Makansi, J. 1993a. Controlling $\mathrm{SO}_{2}$ emissions. Power 137(6): 23-56.

Makansi, J. 1993b. Reducing $\mathrm{NO}_{\mathrm{x}}$ emissions from today's power plants. Power 137(5): 11-28.

Maude, C. 1993. Advanced Power Generation-A Comparative Study of Design Options for Coal. London: International Energy Agency Coal Research.

Miller, S.A., G.J. Vogel, S.M. Gehl, J.E. Hanway, R.F. Henry, K.M. Parker, E.B. Smyk, W.M. Swift, and W.F. Podolski. 1982. Technical Evaluation: Pressurized Fluidized-Bed Combustion Technology. Argonne National Laboratory, ANL/FE-81-65. Washington, D.C.: U.S. Government Printing Office.

MIT. 1993. A Research Needs Assessment for the Capture Utilization and Disposal of Carbon Dioxide from Fossil Fuel-Fired Power Plants. Report of U.S. Department of Energy Grant No. DE-FG02-92ER30194. Cambridge, Massachusetts: Energy Laboratory, Massachusetts Institute of Technology.

NRC. 1992. Policy Implications of Greenhouse Warming. Committee on Science, Engineering, and Public Policy, National Research Council. Washington, D.C.: National Academy Press. 
Ormerod, W.G., I.C. Webster, H. Audus, and W.P. Riemer. 1993. Progress in the Assessment of Technologies for Capture, Utilization and Disposal of Carbon Dioxide. Paper presented at the Eleventh International Conference on Power Stations, Association des Ingenieurs de l'Institut Montefiore, Sept., Liege, Belgium.

Orozco, N.J. 1993. High Pressure Ceramic Air Heater for Indirectly-Fired Gas Turbine Applications. Paper presented at the Joint Contractors Review Meeting, FE/EE Advanced Turbine Systems Conference; FE Fuel Cells and Coal-Fired Heat Engines Conference. U.S. Department of Energy, Morgantown Energy Technology Center. Morgantown, West Virginia, Aug. 3-5.

Pigeaud, E. 1994. Cold Gas Multiple Contaminant Polishing. Paper presented at U.S. Department of Energy Fuel Cells '94 Contractors Review Meeting, Morgantown, West Virginia, Aug. Paper P11.

Preston, G.T. 1992. Advanced Combustion Turbines: Looking Past the 90s. Paper presented at Energy Daily Conference on Advanced Combustion Turbines, Washington, D.C., June 25.

Rubin, E.S., M.B. Berkenpas, H.C. Frey, and B.T. O'Neil. 1993. Modeling the Uncertainty in Hazardous Air Pollutant Emissions. Paper presented at the Second International Conference on Managing Hazardous Air Pollutants, Electric Power Research Institute, Palo Alto, California. July.

Ruth, L. 1994. Low Emission Boilers. Paper presented to the Committee on Strategic Assessment of DOE's Coal Program, the National Academy of Sciences, Washington, D.C., January 13.

Scharer, B., and N. Haug. 1993. Applications of SCR Technology in Germany. Paper presented at the Eleventh International Conference on Power Stations, Association des Ingenieurs de l'Institut Montefiore, Sept., Liege, Belgium.

Sloat, D.G., R.P. Gaikwad, and R.L. Chang. 1993. The potential of pulse-jet baghouses for utility boilers. Part 3: Comparative economics of pulse-jet baghouses, precipitators and reverse-gas baghouses. Journal of the Air and Waste Management Association 43(Jan.): $120-128$.

Takeshita, M. 1994. Fluidized Bed Combustion for Coal-Fired Plants: Environmental Performance. London: IEA Coal Research.

Wolk, R.H., and N.A. Holt. 1994. Overview of Global Utility Market for Advanced Coal-Fired Systems. Paper presented at the Coal-Fired Power Systems 94-Advances in IGCC and PFBC Review Meeting, U.S. Department of Energy, Morgantown Energy Technology Center, Morgantown, West Virginia, June 21-23. 


\begin{tabular}{|c|c|c|c|c|c|c|}
\hline \multirow{2}{*}{\multicolumn{2}{|c|}{ Technology Goals }} & \multicolumn{2}{|c|}{ Advanced Pulverized Coal } & \multirow{2}{*}{$\begin{array}{l}\text { Indirectly Fired Cycle: } \\
\text { Externally Fired } \\
\text { Combined-Cycle/ } \\
\text { High-Performance } \\
\text { Power System }\end{array}$} & \multicolumn{2}{|c|}{ Direct Coal-Fired Heat Engines } \\
\hline & & $\begin{array}{l}\text { Low Emission } \\
\text { Boiler System } \\
\end{array}$ & $\begin{array}{c}\text { Coal-Fired } \\
\text { Cogeneration } \\
\end{array}$ & & $\begin{array}{c}\text { Direct Coal-Fired } \\
\text { Gas Turbines } \\
\end{array}$ & $\begin{array}{c}\text { Direct Coal-Fired } \\
\text { Diesels } \\
\end{array}$ \\
\hline \multicolumn{2}{|c|}{ Net efficiency, percent } & 42 & $\begin{array}{l}70 \text { (total } \\
\text { system) }\end{array}$ & 50 & 40 & 45 \\
\hline \multirow{3}{*}{$\begin{array}{l}\text { Emissions, } \\
\text { fraction of } \\
\text { New Source } \\
\text { Performance } \\
\text { Standards } \\
\text { (NSPS) }\end{array}$} & $\mathrm{SO}_{2}$ & $1 / 3$ & $\begin{array}{l}\text { Meet local } \\
\text { regulations }\end{array}$ & $1 / 10$ & Meet & Meet \\
\hline & $\mathrm{NO}_{x}$ & $1 / 3$ & $\begin{array}{l}\text { Meet local } \\
\text { regulations }\end{array}$ & $1 / 10$ & Meet & Meet \\
\hline & Particulates & $1 / 2$ & Meet & $1 / 4$ & Not specified & Not specified \\
\hline \multicolumn{2}{|c|}{$\begin{array}{l}\text { Air toxics emissions relative } \\
\text { to } 1990 \text { Clean Air Act } \\
\text { amendments }\end{array}$} & Meet & Meet & Meet & Meet & Meet \\
\hline \multicolumn{2}{|l|}{ Solid wastes } & Saleable & Benign & Benign/saieabie & iNot specified & Not specified \\
\hline \multicolumn{2}{|c|}{ Capital cost, $\$ / \mathrm{kW}$} & 1,400 & NA & 1,200 & 1,400 & 1,300 \\
\hline \multicolumn{2}{|c|}{$\begin{array}{l}\text { Electricity cost compared to } \\
\text { current pulverized coal }\end{array}$} & Lower & NA & 10 percent lower & Lower & Lower \\
\hline \multicolumn{2}{|c|}{$\begin{array}{l}\text { Commercial completion } \\
\text { milestones }\end{array}$} & $\begin{array}{c}\text { Commercial } \\
\text { demonstration } \\
\text { by } 2000 \\
1\end{array}$ & $\begin{array}{c}5 \mathrm{MW} \\
\text { demonstration } \\
\text { in } 2001\end{array}$ & $\begin{array}{c}\text { Externally fired } \\
\text { combined-cycle } \\
\text { demonstration-1997; } \\
\text { high-performance power } \\
\text { system } \\
\text { demonstration-2003 }\end{array}$ & $\begin{array}{l}\text { Proof of concept } \\
\text { supporting projects } \\
\text { complete in } 1994\end{array}$ & $\begin{array}{l}\text { 1.8-MW proof-of- } \\
\text { concept demonstration } \\
\text { in } 1994\end{array}$ \\
\hline \multicolumn{2}{|c|}{ Development status } & $\begin{array}{c}\text { Preliminary } \\
\text { commercial } \\
\text { design in } 1994\end{array}$ & $\begin{array}{c}\text { System design } \\
\text { completed in } \\
1994\end{array}$ & $\begin{array}{c}\text { Development and testing } \\
\text { of ceramic heat } \\
\text { exchanger ongoing }\end{array}$ & Complete in 1993 & Complete in 1993 \\
\hline
\end{tabular}

NA, not available.

Source: DOE (1993a). 
Table 7-2 DOE's Program Goals for Pressurized Fluidized Bed Combustion Systems

\begin{tabular}{|c|c|c|c|c|}
\hline & & \multicolumn{3}{|c|}{ Pressurized Fluidized Bed Combustion } \\
\hline \multicolumn{2}{|c|}{ Technology Goals } & First-Generation & $\begin{array}{l}\text { Second- } \\
\text { Generation }\end{array}$ & $\begin{array}{l}\text { Improved Second- } \\
\text { Generation }\end{array}$ \\
\hline \multicolumn{2}{|c|}{ Net efficiency, percent- } & 40 & 45 & $\geq 50$ \\
\hline \multirow{3}{*}{$\begin{array}{l}\text { Emissions, } \\
\text { fraction of } \\
\text { NSPS }\end{array}$} & $\mathrm{SO}_{2}$ & $1 / 4$ & $1 / 5$ & $1 / 10$ \\
\hline & $\mathrm{NO}_{\mathrm{x}}$ & $1 / 3$ & $1 / 5$ & $1 / 10$ \\
\hline & Particulates & Not specified & Not specified & Not specified \\
\hline \multicolumn{2}{|c|}{$\begin{array}{l}\text { Air toxics emissions relative } \\
\text { to } 1990 \text { Clean Air Act } \\
\text { amendments }\end{array}$} & Meet & Meet & Meet \\
\hline \multicolumn{2}{|c|}{ Solid wastes } & Not specified & Not specified & Not specified \\
\hline \multicolumn{2}{|c|}{ Capital cost, $\$ / \mathrm{kW}$} & 1,300 & 1,100 & 1,000 \\
\hline \multicolumn{2}{|c|}{$\begin{array}{l}\text { Electricity cost compared to } \\
\text { current pulverized coal }\end{array}$} & 10 Percent lower & 20 Percent lower & 25 Percent lower \\
\hline \multicolumn{2}{|c|}{$\begin{array}{l}\text { Commercial completion } \\
\text { milestones }\end{array}$} & $\begin{array}{c}\text { Commercial-scale } \\
\text { demonstrations- } \\
\text { mid-1990s }\end{array}$ & $\begin{array}{c}\text { Commercial scale } \\
\text { demonstration- } \\
2000\end{array}$ & $\begin{array}{c}\text { Commercial-scale } \\
\text { demonstration- } \\
2007\end{array}$ \\
\hline \multicolumn{2}{|c|}{ Development status } & $\begin{array}{l}70-\text { to } 80-\mathrm{MW} \\
\text { demonstration } \\
\text { projects ongoing }\end{array}$ & $\begin{array}{c}\text { Systems } \\
\text { development, } \\
\text { integration, and } \\
\text { testing ongoing }\end{array}$ & $\begin{array}{l}\text { Development } \\
\text { initiated }\end{array}$ \\
\hline
\end{tabular}

Source: DOE (1993a). 
Table 7-3 IGCC Power Plant Performance and Economics Based on Shell Gasification Technology and Eastern Bituminous Coal (all costs in constant 1992 dollars)

\begin{tabular}{lr}
\hline Plant Parameter & Value \\
\hline Nominal size, MW & 500 \\
Thermal efficiency (HHV basis) & \\
$\%$ Fuel to power & 42 \\
Net heat rate, Btu/kWh & 8,900 \\
Total capital cost, $\$ / \mathrm{kW}$ & 1,613 \\
Levelized cost of electricity, ${ }^{a}$ mills $/ \mathrm{kWh}$ & 41 \\
\hline
\end{tabular}

${ }^{2}$ Assuming a capacity factor of 80 percent and a levelized coal price of $\$ 1.30 / 10^{6} \mathrm{Btu}$. Source: EPRI (1993a). 
Table 7-4 DOE's Program Goals for Integrated Gasification-Based Systems

\begin{tabular}{|c|c|c|c|c|}
\hline \multicolumn{2}{|c|}{ Technology Goals } & $\begin{array}{l}\text { Second-Generation } \\
\text { Integrated Gasification } \\
\text { Combined-Cycle }^{\mathrm{a}}\end{array}$ & $\begin{array}{l}\text { Integrated Gasification } \\
\text { Advanced-Cycle }\end{array}$ & $\begin{array}{l}\text { Integrated } \\
\text { Gasification Fuel } \\
\text { Cell }\end{array}$ \\
\hline \multicolumn{2}{|c|}{ Net efficiency, percent } & 45 (by 2000) & $\geq 50$ (by 2010) & $\geq 60$ (by 2010 ) \\
\hline \multirow{3}{*}{$\begin{array}{l}\text { Emissions, } \\
\text { fraction of } \\
\text { NSPS }\end{array}$} & $\mathrm{SO}_{2}$ & $1 / 10$ & $1 / 10$ & $1 / 10$ \\
\hline & $\mathrm{NO}_{\mathrm{x}}$ & $1 / 10$ & $1 / 10$ & $1 / 10$ \\
\hline & Particulates & Not specified & Not specified & Not specified \\
\hline \multicolumn{2}{|c|}{$\begin{array}{l}\text { Air toxics emissions relative to } \\
1990 \text { Clean Air Act amendments }\end{array}$} & Meet & Meet & Meet \\
\hline \multicolumn{2}{|l|}{ Solid wastes } & Not specified & Not specified & Not specified \\
\hline \multicolumn{2}{|c|}{ Capital cost, $\$ / \mathrm{kW}$} & 1,200 & 1,050 & 1,100 \\
\hline \multicolumn{2}{|c|}{$\begin{array}{l}\text { Electricity cost compared to } \\
\text { current pulverized coal }\end{array}$} & 20 Percent lower & 25 Percent lower & 20 Percent lower \\
\hline \multicolumn{2}{|c|}{$\begin{array}{l}\text { Commercial completion } \\
\text { milestones }\end{array}$} & Demonstration 2001 & Demonstration 2004 & $\begin{array}{c}\text { Coal } \\
\text { demonstration } \\
2000\end{array}$ \\
\hline \multicolumn{2}{|c|}{ Development status } & Under development & Development initiated & $\begin{array}{c}\text { Current activities } \\
\text { focusing on } \\
\text { natural gas-fired } \\
\text { systems }\end{array}$ \\
\hline
\end{tabular}

${ }^{2}$ First-generation integrated gasification combined-cycle power systems are presently at the commercialization stage and are being demonstrated with design improvements in the CCT program.

Source: DOE (1993a). 
Table 7-5 Major European IGCC Projects in Progress

\begin{tabular}{|c|c|c|c|c|}
\hline Project & Technology & $\begin{array}{c}\text { Efficiency } \\
\text { (percent) }\end{array}$ & $\begin{array}{l}\text { MW } \\
\text { (net) }\end{array}$ & Startup \\
\hline $\begin{array}{l}\text { SEP, Buggenum, } \\
\text { Netherlands }\end{array}$ & $\begin{array}{l}\text { Shell entrained } \\
\text { Oxygen-blown } \\
\text { Cold gas cleanup } \\
\text { Siemens V94.2 gas turbine }\end{array}$ & 41 & 253 & $\begin{array}{c}\text { January } \\
1994\end{array}$ \\
\hline $\begin{array}{l}\text { ELCOGAS, Puertollano, } \\
\text { Spain }\end{array}$ & $\begin{array}{l}\text { PRENFLO entrained } \\
\text { Oxygen-blown } \\
\text { Cold gas cleanup } \\
\text { Siemens V94.3 gas turbine }\end{array}$ & 43 & 300 & Mid-1996 \\
\hline $\begin{array}{l}\text { RWE, KoBra, Hurth, } \\
\text { Germany }\end{array}$ & $\begin{array}{l}\text { HT Winkler fluid bed } \\
\text { Air-blown } \\
\text { Cold gas cleanup } \\
\text { Siemens V94.3 gas turbine }\end{array}$ & 43 & 312 & Post-2000 \\
\hline
\end{tabular}

Source: Wolk and Holt (1994). 
Table 7-6 Integrated Gasification Fuel Cell System Characteristics

\begin{tabular}{lccc}
\hline Parameter & $\begin{array}{c}\text { Phosphoric } \\
\text { Acid Fuel Cell }\end{array}$ & $\begin{array}{c}\text { Molten } \\
\text { Carbonate Fuel } \\
\text { Cell }\end{array}$ & $\begin{array}{c}\text { Solid Oxide } \\
\text { Fuel Cell }\end{array}$ \\
\hline Design plant size $(\mathrm{MW})$ & 150 & 440 & 300 \\
System efficiency on coal (\% HHV) & 33.5 & 51.3 & 46.6 \\
$\mathrm{NO}_{\mathrm{x}}, \mathrm{SO}_{\mathrm{x}}$, VOCs ${ }^{\mathrm{a}}$ total $(\mathrm{lb} / \mathrm{MWh})$ & $<1$ & $<1$ & $<1$ \\
Total capital cost $(1992 \$ / \mathrm{kW})$ & 2,210 & 1,896 & 2,107 \\
$\begin{array}{l}\text { Year of commercial demonstration on natural } \\
\text { gas }\end{array}$ & 1993 & 1998 & 1998 \\
\hline
\end{tabular}

${ }^{2}$ Volatile organic compounds.

Sources: EPRI (1983, 1992a, 1993b). 
Table 7-7 Characteristics of Natural-Gas-Fired Heavy-Frame, and Aeroderivative Combustion Turbine Power Plants

\begin{tabular}{llr}
\hline Turbine-Type & Simple-Cycle & Combined-Cycle \\
\hline Heavy-frame & $140-160 \mathrm{MW}$ & $200-250 \mathrm{MW}$ \\
& $34 \%$ efficiency & $50 \%$ efficiency \\
Aeroderivative & $25-45 \mathrm{MW}$ & $35-55 \mathrm{MW}$ \\
& $36 \%$ efficiency & $47 \%$ efficiency \\
\hline
\end{tabular}

Source: Preston (1992). 
Table 7-8 Combustion-Related Emission Control Systems in the Clean Coal Technology Program

Removal Efficiency (percent)

\begin{tabular}{|c|c|c|c|c|}
\hline Project & $\mathrm{SO}_{2}$ & $\mathrm{NO}_{\mathrm{x}}$ & New & Retrofit \\
\hline \multicolumn{5}{|l|}{ Sulfur Dioxide Removal } \\
\hline Gas suspension absorption & $90+$ & & $\mathrm{X}$ & $\mathrm{x}$ \\
\hline Confined zone dispersion & 50 & & & $\mathrm{x}$ \\
\hline $\begin{array}{l}\text { Furnace sorbent injection with humidification } \\
\text { (LIFAC) }\end{array}$ & 85 & & $\mathbf{X}$ & \\
\hline Advanced flue gas desulfurization & $95+$ & & $\mathrm{X}$ & $\mathrm{X}$ \\
\hline CT-121 flue gas desulfurization system & $98+$ & & $\mathrm{X}$ & $\mathrm{X}$ \\
\hline \multicolumn{5}{|l|}{ NO, Removal } \\
\hline Cyclone fired coal reburn & & 55 & & $\mathrm{X}$ \\
\hline Low-NO $\mathrm{N}_{\mathrm{x}}$ cell burner & & $50+$ & & $X$ \\
\hline Low-NO ${ }_{x}$ burner-gas reburn & & 70 & $\mathrm{X}$ & $\mathrm{X}$ \\
\hline Advanced combustion-wall fired & & 50 & $\mathrm{x}$ & $\mathrm{x}$ \\
\hline Advanced combustion-tangentially fired & & 48 & $\mathrm{X}$ & $\mathrm{X}$ \\
\hline Selective catalytic reduction & & 80 & $X$ & $X$ \\
\hline Micronized coal reburn & & 60 & $\mathrm{X}$ & $\mathrm{X}$ \\
\hline \multicolumn{5}{|l|}{ Combined $\mathrm{SO}_{2} / \mathrm{NO}_{x}$} \\
\hline $\mathrm{SNO}_{x}$ catalytic advanced flue gas cleanup & 96 & 94 & $\mathrm{X}$ & $\mathrm{X}$ \\
\hline Limestone injection multistage burner & 70 & 50 & & $\mathrm{X}$ \\
\hline SNRB combined $\mathrm{SO}_{\mathrm{x}}$ and $\mathrm{NO}_{\mathrm{x}}$ control & 85 & 90 & $\mathrm{X}$ & $X$ \\
\hline Low-NO ${ }_{x}$ burners \& gas reburn & 50 & 70 & & $\mathrm{X}$ \\
\hline $\mathrm{NO}_{x} \mathrm{SO}$ dry regenerable flue gas cleanup & 97 & 70 & $\mathrm{X}$ & $X$ \\
\hline S-H-U $U^{2}$ wet FGD & 95 & 30 & $\mathrm{X}$ & $X$ \\
\hline Dry $\mathrm{NO}_{x} / \mathrm{SO}_{2}$ & $70+$ & $80+$ & $\mathrm{X}$ & $\mathrm{X}$ \\
\hline
\end{tabular}

2 Saarberg Holter Umwelt.

Source: DOE (1994a). 


\section{Technology Demonstration and Commercialization}

EPACT specifically directs DOE to conduct demonstration and commercialization programs on coal-based technologies (Title XIII, Section 1301; see Appendix A, this volume). DOE's CCT program constitutes the major effort in this area, although relevant activities are also being conducted under the Office of FE's R\&D program for coal. The CCT program constitutes a major government-funded effort and provides some useful insights into the role of DOE in facilitating the transition of advanced coal-based technologies from demonstration into the commercial sector. Under the Clinton administration, there is a strong emphasis on accelerating the commercial deployment of new technologies and on developing markets for U.S. technologies both domestically and overseas. In this context the committee has been asked to make recommendations pertaining to EPACT Section 1301(c), subparagraphs $c(3), c(4)$, and c(5) (see Appendix B, this volume). As discussed in Chapter 1, these subparagraphs relate to the requirement for current $\mathrm{FE} \mathrm{RDD \& C}$ programs and the CCT program to deliver commercial technologies by 2010. Recommendations made by the Clean Coal Technology Coalition (CCTC) and the National Coal Council (NCC) for the future of the CCT program are reviewed below. The committee's conclusions and recommendations are given in Chapter 10.

\section{COMMERCIALIZATION ISSUES}

The steps required to commercialize any new technology differ greatly, but the fact that coal is a solid substance introduces a significant technical risk into the technology scale-up process. The difficulty of extrapolating the processing of solids from laboratory through pilot scale to commercial scale is widely recognized. Piloting even at a 1,000 ton/day scale cannot completely ensure the same results at 10,000 ton/day. This differs from processing gases or liquids, where extrapolation from laboratory to full commercial scale in a single step is now commonly practiced, based on an in-depth understanding of the chemical engineering parameters governing such operations. For example, a $14,000 \mathrm{bbl} /$ day commercial Mobil fixed-bed methanol-to-gasoline plant was designed and built based on a $4 \mathrm{bbl} /$ day laboratory unit (Bibby et al., 1988). The difficulty of scale-up when processing solids, such as coal, increases with increasing complexity of the process. Systems that require multiple sequential or tightly integrated solids reactors are at a distinct disadvantage; simplicity is at a premium for solids processing, and this extends to the many auxiliary steps required for the demonstration of a complete coal-fired power generation system. Thus, in scaling-up coal technologies, notably for 
power generation, there is a need for prudent stepwise increases in capacity from laboratory to pilot plant to demonstration scale. The complexity of power generation systems implies that commercialization is particularly expensive.

The objective of the DOE demonstration and commercialization effort is to enhance the process whereby a developing technology is demonstrated at the commercial scale such that it is regarded as commercially available by the ultimate user. In most instances this requires the mitigation or elimination of the additional technological and economic risks that the user associates with the adoption of a new as compared to a proven technology. In the power generation area, the investor-owned utility cannot generally assume the risk of a new technology, faced with a possible loss of return on investment from the rate-making authority if the technology does not perform as expected and requires modification.

It is an accepted principle for advancing new technology to commercial maturity that the first-of-a-kind commercial plant is significantly higher in cost to build than subsequent plants and does not provide adequate information on all operating, maintenance, and cost issues. A new technology is not considered mature and commercially demonstrated until two to five applications of the technology have been installed, as illustrated by the generic capital cost learning curve shown in Figure 8-1. The issue for DOE is how to enhance the installation of additional applications of early demonstrations.

\section{CLEAN COAL TECHNOLOGY PROGRAM}

The CCT program is a technology development effort jointly funded by government and industry in which advanced coal-based technologies are being demonstrated at a scale large enough for the marketplace to judge their commercial potential. A unique feature of the program is that industry plays a major role in defining the demonstration project and in ensuring eventual commercialization. It is intended that once the program is complete the private sector should be able to make use of the technologies developed in the commercial arena without further government support. The industrial partner in each CCT project is required to contribute at least 50 percent of the total cost, indicating the extent of their commitment to develop a technology with a real commercial potential. The patent rights for inventions developed during the demonstration program are normally granted to the industrial participant, thereby preserving the incentives for subsequent commercialization. Five competitive solicitation cycles (CCT Rounds I through V) have been conducted, resulting in 45 active demonstration projects encompassing total public and private investments of $\$ 6.9$ billion, of which DOE is providing $\$ 2.4$ billion (34 percent) and private and other sources are providing $\$ 4.5$ billion (66 percent). Currently authorized funding by solicitation round for the CCT program is given in Chapter 1. From CCT Round III onward, industrial program participants have been required to commercialize technologies in the United States on a best-effort, nondiscriminatory basis, although they cannot be forced to license technologies to their competitors. A summary of CCT activities is provided in Table 8-1. Additional information on demonstration projects in the CCT program is provided in Appendix F. 


\section{ADVANCED POWER SYSTEMS DEMONSTRATION PROJECTS}

DOE's technology goals for the Advanced Power System demonstration projects were given earlier in Chapter 7 (Tables 7-1, 7-2, and 7-4). Many of the technologies being demonstrated in the CCT program are the same as those being targeted in the FE R\&D program. As a result, a number of the CCT demonstrations are also being considered demonstrations under the FE R\&D program, notably, first- and second-generation PFBC, first- and secondgeneration IGCC, IGFC, and mild gasification technology demonstrations. Of the 45 active CCT demonstration projects, 18 are scheduled for completion, 11 will be in operation, and the remaining 16 were in design and construction by the end of FY 1994.

\section{Advanced Emission Control Systems}

Of the 45 active CCT demonstration projects, 19 involve advanced emission control systems technologies aimed at the cleanup of $\mathrm{SO}_{2}, \mathrm{NO}_{x}$, and particulates (see Chapter 7, Table $7-8$ ). The 19 projects require an obligation of $\$ 672$ million (approximately 15 percent of the program funding), of which the private sector has contributed approximately 58 percent. The demonstrations apply to 3,250 MW of generating capacity (units from 5 to $605 \mathrm{MW}$ in size). These activities are expected to have a relatively short-term payoff and result in commercially available technologies for compliance with the acid rain precursor provisions of the Clean Air Act. The technologies being developed also offer significant export potential.

\section{Integrated Gasification Combined Cycle}

A key component for new power generation systems in the near- to mid-term periods (through 2020) will likely be the gas turbine. The fundamental thermodynamic advantage of a heat engine with a $1260^{\circ} \mathrm{C}\left(2300^{\circ} \mathrm{F}\right.$ ) (and rising) inlet temperature over the typical steam turbine with a $540^{\circ} \mathrm{C}\left(1000^{\circ} \mathrm{F}\right)$ inlet is very great and the main reason thermal efficiencies in excess of 50 percent are possible.

In the foreseeable future, gas turbine capacity is anticipated to be in the range of 100 to $300 \mathrm{MW}$, including a combined steam generation cycle. This will require gasification systems that use between 1,000 and 3,000 tons/day of coal. The series of new gasification systems being demonstrated under the CCT program can be expected to achieve these levels, although most still fall in the lower end of the range. IGCC units being demonstrated under the CCT program (see Table 6-3) have capacities of 65 to $480 \mathrm{MW}$ (total capacity of 1,343 MW), and all are scheduled for completion between 1995 and 2000. Thermal efficiencies are predicted to reach 45 percent, with $\mathrm{SO}_{2}, \mathrm{NO}_{\mathrm{x}}$, and particulate emissions well below New Source Performance Standards (NSPS) levels. A discussion of the gasification technologies being demonstrated under the CCT program is given in Chapter 6. 


\section{Pressurized Fluidized-Bed Combustion}

Another new technology being demonstrated is PFBC. Two first-generation PFBC demonstrations, sized at 70 and $80 \mathrm{MW}$, are part of the CCT program, as is a 95-MW secondgeneration PFBC demonstration unit. PFBC technology has the potential to achieve 50 percent thermal efficiencies but only if hot gas cleanup systems can be improved and used in conjunction with advanced turbines (see Chapter 7). PFBC has a very compact footprint that makes it a viable technology for repowering existing generating units.

\section{Direct-Fired Systems}

The technology for direct firing of coal in a gas turbine or diesel engine has been developed through the proof-of-concept phase under the FE R\&D program. In addition, a dual stationary coal-fired diesel engine with a combined rating of $14 \mathrm{MW}$ will be demonstrated in Round $\mathrm{V}$ of the program. This activity is not scheduled to receive any further funding under the FE R\&D program.

\section{Indirectly-Fired Systems}

The FE R\&D program has supported this technology through two programs: EFCC (externally fired combined-cycle) and HIPPS. A demonstration of EFCC technology at the 47MW level is planned for Round V of the CCT program. Continuation of development work on HIPPS is proposed for FY 1995, with a goal of achieving 47 percent thermal efficiency (DOE, 1994b). If the HIPPS technology is to advance to the demonstration phase, the components that will be demonstrated in the CCT EFCC project must prove to be commercially viable. Thus, demonstration of HIPPS technology must await the outcome and economic evaluations of the EFCC demonstration.

\section{Advanced Pulverized Coal Systems}

As noted in Chapter 7, the FE R\&D program is supporting the development of the lowemission boiler system with the goal of demonstrating a 42 percent efficient system with emissions one-half to one-third of the NSPS by the year 2000. For FY 1995, the FE R\&D program has requested $\$ 7.6$ million to continue engineering development and subsystem testing of this technology.

\section{Fuel Cells}

Development and demonstration of fuel cell technology have been transferred from the coal component of the FE R\&D program to the gas component, on the basis that technology 
demonstration and commercialization will likely be accelerated using gas rather than coal. An IGCC demonstration selected in CCT Round V will utilize a portion of the clean coal gas to fuel a $2.5-\mathrm{MW}$ molten carbonate fuel cell.

\section{FUTURE DIRECTIONS}

\section{Additional CCT Solicitations}

Section 1321 of EPACT requires DOE to conduct additional solicitations for the development of cost-effective, higher-efficiency, low-emission coal utilization technologies for commercialization by 2010 . Recommendations for the future of the CCT program have been made by two groups, the CCTC and the NCC.

The CCTC, representing the coal, utility, manufacturing, design, and construction industries and states, advocates the demonstration of clean coal technologies and has made recommendations to DOE regarding the future of the CCT program (CCTC, 1993). The CCTC seeks to ensure that technologies demonstrated in whole or in part through the existing CCT program are also commercially deployed and thereby made ready for "commercial application" as required by Section 1301 of EPACT. The CCTC's specific position regarding Sections 1301 $c(3)$ and $c(4)$ is as follows:

- While continuing to support the completion of the projects already selected in the current CCT program, the program would be modified to address commercial deployment by reducing the financial risks associated with the use of the technologies.

- The program would operate basically as it does now but would cost share only certain cost differentials when compared to a conventional technology. The DOE's cost share of the "risk gap" would be significantly less than the current 50 percent. Specifically, DOE support for commercial demonstration plants would be determined using a risk-based formula to make a given CCT cost competitive with conventional technologies.

With regard to Section $1301 \mathrm{c}(5)$, the CCTC would keep the same program elements and management structure in place, with a revised focus on cost sharing the financial risk. The proposed risk-based formula for determining cost sharing would address both capital cost risk and operating cost risk. As these risks decrease in subsequent demonstrations, so would the costshared DOE support, resulting in eventual commercial acceptance with no cost sharing. Timing of this future program must build on the first-of-a-kind projects and result in commercial acceptance to meet repowering and new capacity requirements from 2005 onward.

The NCC, a federal advisory committee to the Secretary of Energy, has, at the request of the Secretary, made recommendations regarding the future direction of the CCT program (NCC, 1994). The NCC has recommended that no more solicitations be issued under the current CCT program. The NCC further recommends that the Secretary foster the establishment of a new federal-level CCT incentive program to stimulate initial and sustainable commercial deployment of CCT. The recommended CCT incentive program would provide approximately $\$ 1.1$ billion of capital incentives and $\$ 0.3$ billion in operating incentives over the 15 -year period from 1995 to 2010. The incentives would offset 10 to 15 percent of the capital risk and help 
offset operating risks associated with first-of-a-kind and early commercial units. The incentive would be based on a percentage of the capital and operating cost risk differential between the $\mathrm{CCT}$ and conventional technology. For example, if the risk differential between a 400-MW IGCC project and conventional pulverized coal with FGD plant is $\$ 360$ million, the federal incentive for the project would be $\$ 54$ million or 15 percent of the differential.

\section{International CCT Initiative}

Section 1332 of EPACT (Innovative Clean Coal Technology Transfer program) proposes the development of a joint DOE/Agency for International Development clean coal technology program to encourage exports of U.S. technologies that allow more efficient, cost-effective, and environmentally acceptable use of coal resources. FY 1995 funding has been requested to implement an international initiative for "showcase" demonstration projects in clean coal technologies in China and Eastern Europe. Specifically, DOE has proposed that China receive approximately $\$ 50$ million for an IGCC demonstration plant, and $\$ 25$ million in support is proposed for power plant refurbishment in Eastern Europe. DOE expects these funds to be available from projects that were selected in the first five rounds of the CCT program but have or will in the future drop out of the program.

The first priority for the existing CCT program, mandated by Congress in Section 1301 of EPACT, is to conduct a research, development, and demonstration program that will result in CCT technologies that are ready for commercial use by 2010. Thus, in the view of the committee, the impact on the existing CCT program of using CCT program funds to support technology demonstrations in a foreign country requires careful examination. Funding of CCT technology in foreign countries in lieu of domestic demonstrations runs a risk of delivering little if any technology advancement, export opportunities, or lasting U.S. jobs. It is entirely possible that the demonstrations will provide a basis for a foreign country to copy the technology and provide subsequent installations itself.

A further question raised by the committee concerns the suitability of IGCC technology to meet China's major increases in demand for electricity and significant environmental problems. Commercially available pulverized coal plants with modern flue gas cleanup technology may be more cost effective and beneficial (see Chapter 3). Supporting funding for commercially available technology, including retrofit technologies for environmental control, could come from the traditional sources of overseas aid, without impacting the existing CCT program or the FE R\&D program budget.

\section{ADVANCED FUEL SYSTEMS DEMONSTRATION PROJECTS}

As noted in Chapter 2, the objective of the Advanced Fuel Systems program is to develop systems that can produce coal-derived transportation fuels, chemicals, and other products at costs competitive with oil-derived products. At the present time, the prices of coal-derived liquid fuels are significantly greater than of those derived from petroleum or natural gas. Oil prices are not expected to rise sufficiently in the near future to change this situation. As a result, there is 
currently minimal private sector support for developing and demonstrating technologies for the conversion of coal to fuels at a commercial scale. One exception is in mild gasification technology. The FE R\&D program has sponsored a process development unit for mild gasification (the Illinois Mild Gasification Facility) that is supported by 20 percent private sector investment. In addition, the CCT ENCOAL Mild Coal Gasification project aims to demonstrate the production of both a solid and a liquid fuel from coal. This approach has been attempted many times in the past and has not been successful (Probstein and Hicks, 1982), principally because 50 to 70 percent of the feed coal remains as a low-volatile-content char that must be used as a fuel or feedstock. Pyrolysis as a source of liquid fuels has been commercially practiced only under wartime conditions in Germany between 1935 and 1945 based on the Lurgi sweep gas carbonization process. Current efforts have focused on using the char as a boiler fuel or in the production of form coke. The characteristics of the char and the resulting price paid for it have prevented this approach from being economical. DOE has no further plans to use the Illinois Mild Gasification Facility following completion of ongoing development activities. No additional funding for the facility has been requested for FY 1995.

A stand-alone facility for producing finished liquid fuels from coal must necessarily be large to achieve economies of scale and will thus be very expensive. As discussed in Chapter 6 , recent systems studies have projected equivalent crude prices of $\$ 30$ to $\$ 35 / \mathrm{bbl}$ for standalone production of high-quality gasoline and distillate fuels. This cost, combined with the uncertainty in crude oil prices over the operating life of the liquefaction plant, are strong disincentives for demonstration and commercialization projects. However, coproduct systems combining F-T (Fischer-Tropsch) synthesis of coal liquids and electric power generation have the potential to reduce the equivalent crude cost of coal liquids by approximately $\$ 5$ to $\$ 7 / \mathrm{bbl}$ (see Chapter 6, Gray, 1994; Tam et al., 1993). ${ }^{1}$

The above results, together with oil price projections for 2010 (EIA, 1994), indicate that demonstration and early deployment of liquefaction technology in coproduct systems may become economically attractive within the mid term (2006-2020), that is, in approximately the same timeframe as installation of advanced IGCC power generation facilities. Nevertheless, the price projections from the studies assume " $n$th plant" costs. As for advanced power generation technologies, first-of-a-kind or pioneer plant demonstrations are likely to be significantly more expensive than fully commercial systems. Thus, the committee anticipates that some federal cost sharing of early demonstration plants, similar to that in the CCT program, will be necessary to stimulate industry participation, and ultimate adoption, of coproduct systems to produce coal liquids and electric power.

\section{FINDINGS}

1. Demonstration of advanced coal-based technologies at a commercial scale, as in the FE R\&D and CCT programs, is an important step in the development of commercially available technologies. The demonstrations being supported by the FE R\&D and CCT programs appear,

\footnotetext{
${ }^{1}$ In the studies cited the economic return on electric power production was assumed to be consistent, with the savings applied to the liquid products.
} 
for the most part, to be well directed toward advancing power generation technologies that have the potential to meet relevant goals for thermal efficiency, environmental control, and reduced costs.

2. The program components and management of the current CCT program have demonstrated the ability to conduct a successful demonstration program, as evidenced by the involvement and financial support of the private sector.

3. The commercial acceptance of new power generation technologies will be impeded by the remaining financial risk associated with second- and third-of-a-kind demonstration projects.

\section{REFERENCES}

Bibby, D.N., C.D. Chang, R.F. Howe, and S. Yurchak. 1988. Methane conversion. P. 251 in Proceedings of the Symposium on Production of Fuels and Chemicals from Natural Gas, April 27-30, 1987, Auckland, New Zealand. Amsterdam: Elsevier Science Publishers.

CCTC. 1993. Recommendations made by the Clean Coal Technology Coalition to the Department of Energy on the Future of the CCT Program, Oct. 6.

DOE. 1994a. Clean Coal Technology Demonstration Program, Program Update 1993. U.S. Department of Energy, DOE/FE-0299P. Washington, D.C.: DOE. .

DOE. 1994b. FY 1995 Congressional Budget Request. U.S. Department of Energy, DOE/CR0023, Vol. 4. Washington, D.C.: DOE.

EIA. 1994. Annual Energy Outlook 1994. Energy Information Administration, U.S. Department of Energy, DOE/EIA-0383(94). Washington, D.C.: DOE.

Gray, D. 1994. Coal Refineries: An Update. Prepared for Sandia National Laboratories by the Mitre Corporation under contract no. AF-7166. McLean, Virginia: The Mitre Corporation.

NCC. 1994. Clean Coal Technology for Sustainable Development. Washington, D.C.: National Coal Council.

Probstein, R.F., and R.E. Hicks. 1982. Synthetic Fuels. New York: McGraw-Hill.

Tam, S.S., D.C. Pollock, and J.M. Fox. 1993. The combustion of once-through FischerTropsch with baseload IGCC technology. P. 306 in Alternate Energy '93 held April 28-30, in Colorado Springs, Colorado. Arlington, Virginia: Council on Alternate Fuels. 


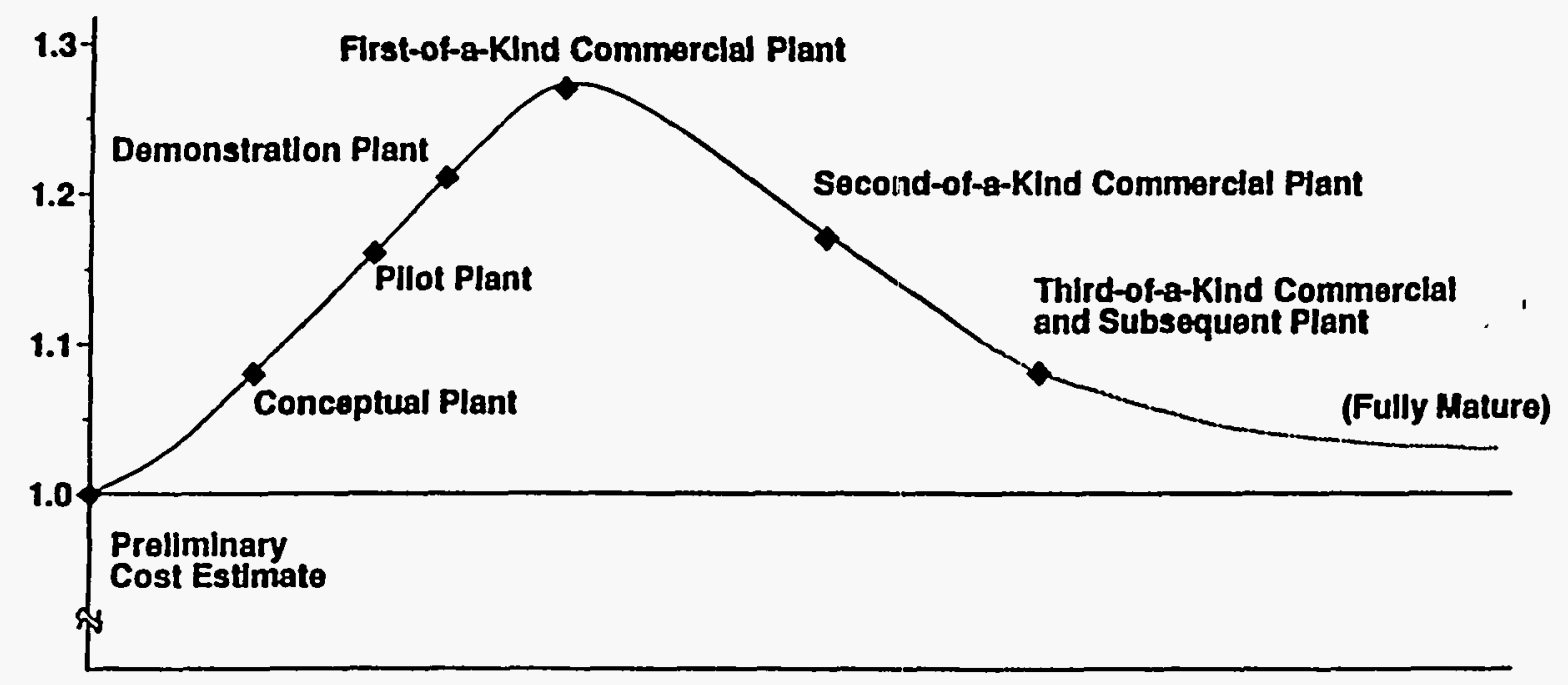

Figure 8-1 Capital cost learning curve. 
Table 8-1 Summary of CCT Activities

\begin{tabular}{|c|c|c|c|}
\hline Round & Principal Goals & $\begin{array}{l}\text { Number of } \\
\text { Proposals } \\
\text { Submitted }\end{array}$ & $\begin{array}{l}\text { Number of Projects } \\
\text { Selected; Current } \\
\text { Status }\end{array}$ \\
\hline I & $\begin{array}{l}\text { Demonstrate feasibility of clean coal } \\
\text { technologies for future commercial } \\
\text { applications }\end{array}$ & $51^{\mathrm{a}}$ & $\begin{array}{l}9 \text { plus } 14 \text { alternates; } \\
1 \text { complete, } 8 \\
\text { ongoing, including } 3 \\
\text { alternates }\end{array}$ \\
\hline II & $\begin{array}{l}\text { Demonstrate technologies: } \\
\text { - Capable of being commercialized in } 1990 \mathrm{~s} \\
\text { - More cost effective than current } \\
\text { technologies } \\
\text { - Capable of achieving significant reduction } \\
\text { of } \mathrm{SO}_{2} \text { and } \mathrm{NO}_{x} \text { emissions from existing } \\
\text { facilities }\end{array}$ & 55 & $\begin{array}{l}\text { 16; } 4 \text { withdrawn, } 12 \\
\text { ongoing }\end{array}$ \\
\hline III & $\begin{array}{l}\text { Demonstrate technologies capable of: } \\
\text { - Being commercialized in } 1990 \text { s } \\
\text { - Achieving significant reductions in } \\
\text { emissions of } \mathrm{SO}_{2} \text { and/or } \mathrm{NO}_{\mathrm{x}} \text { from existing } \\
\text { facilities } \\
\text { - Providing for future energy needs in } \\
\text { environmentally acceptable manner }\end{array}$ & 48 & 13 ; all ongoing \\
\hline IV & $\begin{array}{l}\text { Demonstrate technologies capable of: } \\
\text { - Retrofitting, repowering, or replacing } \\
\text { existing facilities while achieving significant } \\
\text { reductions in } \mathrm{SO}_{2} \text { and/or } \mathrm{NO}_{x} \text { emissions } \\
\text { - Providing for future energy needs in } \\
\text { environmentally acceptable manner }\end{array}$ & 33 & $\begin{array}{l}9 ; 2 \text { withdrawn, } 7 \\
\text { ongoing }\end{array}$ \\
\hline V & $\begin{array}{l}\text { Advance efficiency and environmental } \\
\text { performance of coal-using technologies } \\
\text { applicable to new or existing facilities }\end{array}$ & 24 & $\begin{array}{l}\text { 5; pending final } \\
\text { approval }\end{array}$ \\
\hline
\end{tabular}

aThe majority of the proposals were for four technologies: coal preparation (10), coal gasification (10), atmospheric fluidized-bed combustion (9), and flue gas cleanup (7). Source: DOE (1994a). 


\section{Advanced Research Programs}

The present chapter provides a brief overview of the organization and budgets for the DOE's Office of FE advanced research programs relating to coal. The DOE and committee perspectives on the role of advanced research for coal-based technologies are then presented. The chapter concludes with a brief discussion of opportunities for advanced research in three areas: combustion and gasification, coal conversion and catalysis, and materials. It is not the intention of the committee to provide a comprehensive list of research opportunities for coal-based technologies but rather to highlight key areas. The specific research opportunities discussed were identified by the committee on the basis of its review and analysis of current DOE programs (Chapters 5 through 7), and particular importance was accorded activities unique to coal technologies. In each case the proposed research is directed toward meeting, and ultimately exceeding, DOE's targets for advanced coal-based power systems and the production of clean fuels from coal.

\section{PROGRAM ORGANIZATION AND BUDGETS}

The advanced research programs within the DOE FE coal R\&D program consist of a set of cross-cutting programs within the AR\&TD (Advanced Research and Technology Development) budget category and a set of technology-specific programs falling under the general category of Advanced Research and Energy Technology (AR\&ET), formerly known as Advanced Research. The AR\&ET technology-specific programs fall within the Advanced Clean Fuels and Advanced Clean/Efficient Power Systems budget categories (see Table 2-1). This program organization responds to a directive from Congress stating that, for ease of budget presentation and receiving testimony, advanced research directly related to a specific coal area should be presented both in the budget and in testimony as part of the total program for that specific technology area, rather than as part of the A.R\&TD budget category.

The AR\&TD program includes both research and nonresearch portions. The Technology Crosscut activities within AR\&TD (see Chapter 2) include all nonresearch areas, namely, Environmental Activities, Technical and Economic Analyses, International Program Support, and Coal Technology Export, as well as two advanced research areas, specifically, Instrumentation and Diagnosis and Bioprocessing of Coal. For the purposes of the present discussion, the nonresearch portion of the AR\&TD program will not be considered, and corresponding budget data are not included in Tables 9-1 and 9-2. 
Table 9-1 presents the funding history of advanced research programs on coal since 1988. The 1995 budget request represents the DOE and administration proposal to Congress. When these budget numbers are expressed in constant dollars, it can be seen that there was a decrease of approximately 30 percent in the advanced research budget between FY 1988 and FY 1994, with an additional decrease of approximately 25 percent from the FY 1994 level proposed for FY 1995.

A more detailed comparison between the FY 1994 enacted appropriation and the 1995 congressional request is shown in Table 9-2, which also shows in more detail the advanced research activities funded under AR\&TD and AR\&ET. Major budget reductions are proposed in FY 1995 for the programs in materials ( 25 percent), components (50 percent), and, most notably, coal liquefaction (85 percent). It is proposed that the FY 1994 budget of $\$ 5.2$ million for coal liquefaction be reduced to \$0.8 million in FY 1995 .

\section{THE ROLE OF ADVANCED RESEARCH}

\section{DOE Perspective}

A perspective on the mission, vision, and goals of the $\mathrm{FE}$ advanced research activities is provided in a recent document from DOE (1994b). The role of advanced research within the FE program is "to stimulate, nurture, and advance critical enabling science and technologies for fossil energy systems." A series of advanced research goals, strategies, and success indicators have been selected to support relevant DOE business lines and the core Office of FE business lines of clean fuel systems and clean/efficient power systems (see Chapter 2) and to directly reflect customer and stakeholder expectations. The goals are as follows:

1. Provide the core competencies in the critical enabling science and technologies that enable the Office of FE business lines to succeed in their missions.

2. Through feasibility testing, identify and nurture innovative concepts for advancing the technology and removing barriers to achieving the Office of FE's business line goals.

3. Provide the fundamental data, information, materials, and tools required by the U.S. fossil energy industry to bring advanced fossil energy systems to commercial fruition.

4. Improve the environmental performance of fossil energy systems by performing research that significantly increases system efficiencies, provides advanced environmental control systems, and shifts from waste management to pollution prevention/waste minimization.

\section{The Committee's Perspective}

Based on its analysis of likely future trends in coal use and ongoing DOE coal programs, the committee observed that the use of coal for power generation is confronting an increasingly demanding set of requirements. Following many years of gradual improvement of pulverized coal-steam turbine baseload power systems, with limited add-ons for emissions control, there is a need for greatly enhanced technology for emission control, for improved efficiency, and for 
improvements in the overall economics of power generation. Similarly, during the time periods considered in this study it is probable that liquid and gaseous fuels manufactured from coal will be needed. Improvements in the cost and efficiency of manufacturing processes will depend on further advances in the chemistry and engineering related to coal use.

In light of the continuing needs for advances beyond the 2010 targets defined for the power systems and fuels programs (Chapter 2) and the goals defined in DOE's Strategic Plan (DOE, 1994a), the committee identified a critical role for DOE advanced research programs on coal. Such programs have the potential to exploit the extensive opportunities for improved coal technology while compensating for the decline in industrial and non-DOE government support for long-range research on coal. The optimum role for DOE differs from one advanced research area to another but is largely determined by technology needs and their degree of specificity to coal-based systems and by complementary research activities in industry and government organizations outside DOE. The following discussions of some major research areas address opportunities for DOE advanced research programs to contribute to the development of coal technologies. The research areas discussed are combustion and gasification, coal conversion and catalysis, and materials.

\section{COMBUSTION AND GASIFICATION}

Research on oxidation of fuels to provide useful energy with acceptable emissions is the subject of a large international activity. Much current work relates to gas-phase reactions and to soot formation and oxidation (see, for example, The Combustion Institute, in press). However, coal combustion research falls outside these areas because of the large amount of char formed by the pyrolysis step and because of the ash content of coal. Problems directly related to coal-such as emissions, waste products, and char oxidation efficiency-are receiving far less attention than problems relating to other fuels. Much of the recent advanced research on coalrelated combustion issues, notably the interaction with coal ash and the final stages of oxidation, has been conducted in the United States, principally under DOE and, to a lesser extent, National Science Foundation sponsorship. The committee noted that, in the absence of research needs and funding from other sources, DOE support is important to achieve progress in quantitative understanding of coal-related combustion and gasification issues and to identify innovative concepts for further investigation.

While still a promising area for research, gas-phase chemistry of $\mathrm{NO}_{\mathrm{x}}$ formation and destruction and of the oxidation of carbon monoxide ( $\mathrm{CO}$ ) and hydrocarbons, has advanced to the point where simplified gas kinetic models can be used in conjunction with primitive turbulence modeling as a semiquantitative design and development tool for low-emission furnaces and gas turbine combustors. However, in the case of coal, the early release of gas-phase hydrogen cyanide introduces $\mathrm{NO}_{\mathrm{x}}$ production pathways not yet quantitatively explored. Moreover, promising research opportunities still exist, including implementation of more sophisticated models. In contrast, the understanding and quantitative treatment of carbon kinetics, taking into account catalytic and physical interactions with ash and graphitization of carbon as the oxidation process proceeds, is at a relatively primitive stage. Since future innovations in coal gasifier and combustor design will depend, to a considerable extent, on quantitative 
understanding of the interaction between pyrolysis, carbon oxidation, and emissions, the committee noted that DOE's advanced research program for coal needs to address this issue.

The final stage of carbon oxidation is of special interest because of the observed reduction of reactivity at high conversion rates (Davis et al., in press). The long reaction times and high temperatures required for high carbon conversion will increase thermal $\mathrm{NO}_{\mathrm{x}}$ formation in the presence of excess air. The interactions involved are complex, and improved quantitative understanding of the evolution of carbon reactivity and its interaction with the physical and catalytic properties of the coal ash is needed for choice of optimum levels of carbon oxidation.

Two major advanced research opportunities were identified by the committee as a basis for improving high-performance gasification systems. In low-temperature and countercurrent fixed-bed gasification processes, escape of fuel nitrogen as ammonia can occur, resulting in the formation of additional $\mathrm{NO}_{\mathrm{x}}$ on combustion if not removed. Quantitative treatment of this problem is needed for improvement of these processes. For low-temperature gasification processes where high carbon conversion is needed, catalysis of carbon gasification by ash constituents, such as calcium, or by added catalysts remains a promising area related to future advances in gasification efficiency.

\section{COAL CONVERSION AND CATALYSIS}

The complexity of coal structure and chemistry has important implications for conversion technologies and catalysis. Coals are inhomogeneous on the macroscopic, microscopic, and molecular levels. They are insoluble, opaque, macromolecular systems composed of a mixture of organic and inorganic constituents. While knowledge of coal's physical and chemical structures remains rudimentary, knowledge and understanding of coal reactivity are even more limited. Most of the available tools for determining chemical structure are designed to work with systems of pure compounds and either do not work when applied to coals or become much more complex in their application. The efficacy of solid catalysts when used with solid coals decreases very significantly compared to their effectiveness in fluid systems. Opportunities exist to develop entirely new catalysts that will contact coals and effect desired reactions. The committee identified a role for DOE in supporting advanced research on coal conversion and catalysis to ensure the cleanest and most efficient utilization of coal, consistent with the goals of the advanced fuels and power systems programs, and to compensate for the absence of significant industrial research in this field.

In reviewing current DOE coal advanced research programs, the committee particularly noted the decline in efforts devoted to coal liquefaction technology. Given the likely growth in importance of coal liquids in the mid and long term, as described in the committee's strategic

planning scenarios (see Chapter 4), the committee identified coal liquefaction as an important area for advanced research within the DOE coal program. Industrial transformations of fossil fuels are catalytic, and the creation of new and improved catalysts and better reactors to use those catalysts has been a central thrust of fuel chemistry for almost a century. The use of catalytic chemistry with coals presents unique and difficult problems. Since coal is a solid, it cannot move around into contact with a catalyst surface. Thus, the use of immobile solid catalysts typical of oil and gas processing is not possible with coal. It is necessary either to 
render the coal fluid, to use catalysts of extraordinarily high dispersion, or to use catalysts that are themselves mobile fluids. All three approaches have been used with some success, and there has been a fairly continuous improvement in catalysts used. Further enhancements can be anticipated based on a mix of applied and fundamental studies on topics such as highly dispersed catalysts, diffusion in coals and coal-catalyst contacting, and effective mobile catalysts. Both lower-temperature catalysts and more selective chemistries have the potential to reduce costs.

Research opportunities can be conveniently divided into two major categories: improvements in current processing chemistry and technology and liquefaction processes based on new chemistries. Possible improvements in chemistry and technology (see also Chapter 6) include:

- low-pressure reaction at $2.17 \mathrm{MPa}$ (300 psig) or less;

- use of low-cost subbituminous coal or lignite, especially deposits having high hydrogen-to-carbon ratios;

- removal of coal oxygen as carbon dioxide;

- complete conversion to liquids with boiling points below $540^{\circ} \mathrm{C}\left(1000{ }^{\circ} \mathrm{F}\right)$;

- improved selectivity to minimize production of hydrogen, water, and hydrocarbon gases;

- coproduction of high-value chemical and other nonfuel products; and

- direct use of gas from IGCC systems equipped with hot gas cleanup for F-T synthesis and to produce hydrogen for direct liquefaction.

For direct liquefaction, existing processes require cold gas cleanup, shifting to convert carbon monoxide and water to hydrogen and $\mathrm{CO}_{2}$, and scrubbing to remove $\mathrm{CO}_{2}$. There would be significant energy and capital cost savings if the hot gasifier gas could be used without cooling and further processing. Water/gas shift activity in the catalyst system used would be desirable; however, currently available catalysts are not sufficiently sulfur resistant. The use of hot gasifier product for F-T synthesis would require new catalysts capable of carrying out the reaction in the presence of the sulfur concentrations and traces of heavy metals remaining after hot gas cleanup. More active or selective sulfur-tolerant catalysts could markedly improve both direct liquefaction and the upgrading of coal liquids.

Alternative process chemistries of potential interest include

- coprocessing based on alkylation or transalkylation chemistry rather than hydrogenation,

- oxidative depolymerization to oxygenate fuels, and

- new depolymerization chemistry followed by fixed-bed catalytic upgrading.

The DOE AR\&TD budget for bioprocessing of coal was $\$ 1.9$ million in FY 1994, and the same funding has been proposed for FY 1995. The main thrusts of the bioprocessing program in recent years have been to explore and apply recent advances in biotechnology to convert coal to liquid fuels and to improve the environmental acceptability of advanced power systems. Activities have included characterization of the metabolic features of bacteria found to remove organic sulfur, mineral matter, and metals from coal and investigation of mechanisms 
for bioconversion of coal. Most experts in the field now agree that biotechnology is best suited for the manufacture of high-value-added products and is least well suited for the production of very large amounts of low-value-added materials, as in the case of coal processing. Thus, current and proposed future DOE coal program efforts in biotechnology will focus on cleanup of sulfur- and nitrogen-containing compounds in combustion gases, rather than on coal desulfurization and demineralization. The committee notes that, although there are possible opportunities for biological cleanup of flue gas $\left(\mathrm{NO}_{\mathrm{x}}\right.$ and $\mathrm{SO}_{2}$ removal), significant technological difficulties remain because of the relatively long processing times and large volumes of gas to be treated.

\section{MATERIALS}

\section{General Comments}

R\&D aimed at developing high-performance materials designed to operate in hostile environments is a very large and active area of endeavor worldwide. Given the limited resources of DOE's coal advanced research program in materials, the committee identified a need for this program to focus on key materials development issues for coal-based technologies while leveraging more generic materials developments from other programs.

The preceding review of DOE's coal R\&D programs given in chapters 5 through 7 has been used by the committee as a basis for identifying opportunities in materials research specific to coal-based technologies. Three areas have been selected for emphasis and are discussed below: advanced gas turbines; high-temperature, high-pressure heat exchangers; and inorganic membranes. The present discussion is not intended to provide an exhaustive list of materials research opportunities relevant to the coal program but rather to highlight key materials-based enabling technologies critical to the success of DOE programs in advanced clean fuels and advanced power systems.

\section{Advanced Gas Turbines}

Many of the advanced coal-based power generation technologies currently being developed incorporate gas turbines (e.g., IGCC, advanced PFBC, direct coal-fired gas turbines, and IFC [indirectly fired cycles]). Thus, gas turbines constitute a key component in advanced coal-based power generation technologies.

The ATS (advanced turbine systems) program, funded under the natural gas component of the FE R\&D program budget, aims to develop advanced land-based turbines for natural gas systems but adaptable to coal- or biomass-derived fuels. The systems efficiency target using natural gas is greater than 60 percent based on lower heating value (approximately 55 percent HHV equivalent). Many generic materials issues, ${ }^{1}$ such as increased temperature capability and extended operating lifetime, are being addressed in the ATS program by DOE and industry

'See NRC (1986) for an assessment of materiais needs for large land-based gas turbines. 
participants, and related developments for natural-gas-fired turbines should be broadly applicable to turbines using coal-derived fuels. The committee recommends that activities in the FE coal $\mathrm{R} \& \mathrm{D}$ program focus on materials issues specific to the use of coal-derived fuels in advanced turbines.

All attempts to date to direct fire gas turbines with coal have resulted in significant ash deposition and corrosion of hot gas path components as a result of the aggressive chemical nature of the products of coal combustion (LaHaye and Bary, 1994). The development of turbine materials capable of surviving the hostile environment of direct coal-fired systems represents a major challenge. In the case of gasification-based systems, the environmental constraints imposed on the turbine materials are less demanding than in the case of direct coal firing but more severe than in a natural-gas-fired system. Coal gasification produces a raw syngas consisting mainly of carbon monoxide and hydrogen but with substantial quantities of $\mathrm{CO}_{2}$ and water; minor quantities of hydrogen sulfide, ammonia, and hydrogen chloride; and a few parts per million of alkali metals (NRC, 1986). While unprocessed natural gas can contain large amounts of hydrogen sulfide, pipeline natural gas contains no hydrogen sulfide and a sulfur weight fraction of only 0.000007 (DeLuchi, 1993).

The major issue associated with the use of coal-derived gas in advanced turbines is the effect of contaminants, notably sulfur and alkali metals, on turbine performance (operating temperature and lifetime). Possible penalties in the overall efficiency of gasification-based systems can be anticipated based on the need to operate at lower temperatures to reduce the corrosive effects of contaminants in the coal-derived gas. Corrosion is also likely to severely reduce the lifetime of the turbine components. The ability of hot gas cleanup systems to reduce contaminants to levels acceptable for high-temperature advanced turbines has not yet been demonstrated. Reverting to cold gas cleanup would involve an efficiency penalty of one to three percentage points.

From a materials perspective, the critical issue for coal gas-fired systems is the extent to which corrosion-resistant turbine blade materials and coatings can increase the environmental tolerance of advanced turbines, thereby reducing (or eliminating) the need for gas cleanup and possible associated efficiency penalties. Allowable levels of contaminants depend on engine design and turbine pressures and temperatures, but the corrosion problem is likely to be the most severe for the first-stage blades that are exposed to the highest temperatures and the full concentration of impurities in the gas stream (Bernstein and Allen, 1992).

Given the increased likelihood of environmental attack, evaluation of candidate material systems for coal-fueled turbine systems is necessary, with an accompanying search for better materials. The superalloys currently used for turbine blades are generally protected from hightemperature oxidation and corrosion attack by a variety of coatings. Formation on the coating surface of reaction products-specifically, adherent alumina or chromia scales-retards subsequent reaction between the coating and the environment. A recent review of hightemperature coatings for combustion turbine blades (Bernstein and Allen, 1992) addresses coating requirements for protection from different types of environmental attack.

Since fuel type is probably the most important variable influencing the choice of a coating, the use of gas derived from coal gasification is likely to have a significant impact on the choice of turbine blade coatings. The complex chemical reactions that occur at high temperatures, and the susceptibility of these reactions to small chemical changes in the coating 
and gaseous environment, suggest that significant effort will be necessary to develop and evaluate coatings for turbines used in coal gasification-based power systems. There are a large number of commercial coatings available, and a number of different application methods that influence the coating behavior, but there is no one coating that is resistant to all types of hightemperature attack. It has been suggested that in systems using coal-derived fuel, coatings on advanced superalloys and the alloys themselves will need to form chromia rather than alumina scales for increased corrosion resistance (Bannister et al., 1994). In the case of the substrate (blade) materials, this constraint may limit the availability of suitable high-strength alloys.

Recently, the use of thermal barrier coatings (TBCs) has proven extremely useful in extending the temperature capabilities of existing superalloys. TBCs are ceramic coatings applied over metal substrates to insulate them from high temperatures. They consist of a layer of stabilized zirconium oxide that is 0.12 to $0.38 \mathrm{~mm}$ ( 0.005 to 0.015 inches) thick applied over a bond coat composed of an oxidation-resistant metal coating. Although TBCs themselves are expected to be only minimally corroded by the more aggressive environment in coal-fueled turbines, both the substrate and the bond coat may be adversely affected.

The development of alternative turbine materials with higher-temperature capability than existing superalloys-notably monolithic ceramics and ceramic matrix composites-is being addressed in the ATS program. The potential improvements in high-temperature corrosion resistance of ceramic materials compared to state-of-the-art superalloys is of interest for turbines using coal-derived fuels.

\section{Heat Exchangers}

In terms of materials behavior, the critical requirements for the ceramic heat exchanger for EFCC power generation systems (see Chapter 7) are

- to maximize operating temperatures for the proposed duty cycle, notably combinations of high temperature and pressure;

- to resist fouling and alkali corrosion, with emphasis on the latter for low-rank coals; and

- to avoid catastrophic failure.

Although advanced ceramics offer excellent high-temperature properties, such as high strength, corrosion and erosion resistance, and refractoriness, they are subject to brittle fracture due to critical flaws. High-velocity fragments from a failed ceramic tube have the potential to initiate rapid sequential failure of the array of ceramic tubes in the heat exchanger. The current proprietary tube design permits "graceful" rather than catastrophic failure.

Advanced structural ceramics with increased temperature capability and improved toughness are under development in a number of government/industry programs, including the ATS program (see above), the Integrated High-Performance Turbine Energy Technology program, including the U.S. Air Force, Navy, Army, Advanced Research Projects Agency, and the National Aeronautics and Space Administration (NASA), and the NASA Enabling Propulsion Materials program. Materials developed in these and other programs for high-temperature gas 
turbine applications may offer the higher operating temperatures and improved brittle fracture characteristics required for the ceramic heat exchanger in EFCC power generation systems. Since the proposed ceramic heat exchanger involves no moving parts, it is significantly less susceptible to deterioration from ash deposition or corrosion than are rotating components in the gas path of a turbine (LaHaye and Bary, 1994). However, the ash deposition and corrosion problems encountered using pulverized coal and the high-pressure cycles encountered in EFCC applications are unlikely to be addressed in materials development programs that are not targeted at coal-based technologies. In the view of the committee, the DOE coal materials program should focus on such issues specific to coal-based systems.

Current materials development and testing of the ceramic heat exchanger for EFCC systems is being conducted by Hague International (Orozco and Vandervort, 1993; Vandervort et al., 1993; Orozco, 1993; LaHaye and Bary, 1994). Activities are focusing on pressure and environmental testing. Over 2 million hours of successful operation of low-pressure ceramic heat exchanger units in corrosive high-temperature industrial environments has already been demonstrated. A series of tests is planned to demonstrate that a complete ceramic heat exchanger can contain pressures up to $1.21 \mathrm{Mpa}$ (175 psia), endure at least 100 hours of operation under static and dynamic loadings, and meet thermal performance requirements. During these tests, the combustor will be fired with natural gas for operational simplicity. Subsequent testing with a coal-fired combustor will verify the ability of the slag screen to protect the ceramic heat exchanger from coal ash.

Ceramic materials demonstrate superior corrosion resistance compared to conventional metals and superalloys but can be severely degraded by alkali metals in coal combustion products. In particular, nonoxide ceramics such as silicon carbide (SiC) corrode in an oxidizing environment. The corrosion process is affected by the material processing technique, grain size, and impurity content. Hague International has conducted a series of corrosion tests on $46-\mathrm{cm}$ (18-inch) long, $2.5-\mathrm{cm}$ (1-inch) diameter tubular coupons of candidate heat exchanger materials, notably, an alumina matrix composite, reaction-bonded $\mathrm{SiC}$, mullite (orthorhombic aluminum silicate, $\left.\mathrm{Al}_{6} \mathrm{Si}_{2} \mathrm{O}_{13}\right)$, and monolithic alumina $\left(\mathrm{Al}_{2} \mathrm{O}_{3}\right)$. Preliminary results indicate that mullite shows the highest temperature capability and good corrosion resistance. After 300 hours at 1090 ${ }^{\circ} \mathrm{C}\left(2000^{\circ} \mathrm{F}\right)$ with brief excursions to $1480^{\circ} \mathrm{C}\left(2700^{\circ} \mathrm{F}\right)$, little corrosion was observed.

Despite performance enhancements in advanced ceramics, a temperature limit of approximately $1090^{\circ} \mathrm{C}\left(2000{ }^{\circ} \mathrm{F}\right)$ currently exists for ceramic heat exchanger materials. A report published in the late 1980s (OTA, 1988) noted that federal government support has been necessary to accelerate development of the ceramic materials and system technology for heat exchangers, despite projected economic and performance advantages. Material manufacturers and end users have considered the technical risks too high to invest their own funds in systems development and implementation.

\section{Membranes}

Membranes play a key role in the production of fossil-fuel-based products that meet composition standards for engine and combustor performance and provide environmental compliance through the removal of pollutant molecules (NRC, 1993). Possible applications of 
membranes to coal-based systems include the separation of hydrogen from coal gas streams and of impurities such as hydrogen sulfide $\left(\mathrm{H}_{2} \mathrm{~S}\right)$, ammonia $\left(\mathrm{NH}_{3}\right), \mathrm{SO}_{2}, \mathrm{NO}_{x}$, and trace metal compounds from coal conversion (e.g., gasification) and combustion (flue gas) streams. Such separations can account for a major fraction of the investment and operating cost for coal-based systems. A particularly important application for advanced clean/efficient power systems is the cleanup of coal gasification streams to drive advanced turbines. As discussed above, the ability of hot gas cleanup systems to reduce the contaminants to levels acceptable for high-temperature advanced turbines remains to be demonstrated. Another possible application of membranes is for the separation of methane from very dilute coalbed methane streams (see Chapter 5).

Low-temperature polymer membrane technology is fairly well developed and is useful for liquid-liquid, liquid-gas, and gas-gas separations (DOE, 1992). However, polymer membranes are limited to relatively low temperatures (less than $250^{\circ} \mathrm{C}$ [480 $\left.{ }^{\circ} \mathrm{F}\right]$ ) and are subject to chemical and abrasive attack, particularly in the aggressive environments encountered in coal-based systems. Inorganic (ceramic) membranes have the potential to operate at the high temperatures required for advanced power generation systems (e.g., $815^{\circ} \mathrm{C}\left[1500{ }^{\circ} \mathrm{F}\right]$ for removal of hot gas particulates from advanced PFBC and IGCC systems) and to provide significantly enhanced corrosion and erosion resistance compared to polymer membranes. Other expected advantages of advanced inorganic membranes include high permeability (1,000 to 10,000 times organic membrane permeability) and high selectivity (DOE, 1993).

In materials terms, refractory behavior and resistance to environmental attack depend on a suitable choice of ceramic material and associated fabrication process. Possible problems can be anticipated in coal-based systems due to reaction of candidate ceramic membrane materials-such as alumina, zirconia, and silica-with gas stream components, notably $\mathrm{SO}_{2}$ and alkali metals, at temperatures in the range of $540{ }^{\circ} \mathrm{C}$ to $1090^{\circ} \mathrm{C}\left(1000{ }^{\circ} \mathrm{F}\right.$ to $\left.2000{ }^{\circ} \mathrm{F}\right)$. The presence of steam is likely to accelerate the degradation process. Requirements for high separation efficiency impose further materials constraints in terms of pore size distribution and mean pore size in the membrane. A high degree of control during membrane fabrication is necessary to achieve the desired microstructural features. Ceramic membranes consist of a porous support a few millimeters thick, a porous intermediate layer 10 to 100 microns thick with pore diameters in the range of 0.05 to 0.5 microns, ${ }^{2}$ and the separation layer with a thickness of 1 to 5 microns (Burggraaf et al., 1989). Generally, the separation layer must have pore diameters less than $10 \mathrm{~nm}$ for effective separation of gaseous components by diffusion (Krishnan et al., 1993); in some cases a mean pore size of $2.5 \mathrm{~nm}$ may be necessary. ${ }^{3}$

Current commercially available membranes do not meet all performance requirements for cleanup of coal-gas and flue gas streams, although several manufacturers produce inorganic membranes for micro- and ultrafiltration applications, and some of these have pore diameters less than $10 \mathrm{~nm}$ and are capable of separating gaseous components. However, extensive membrane technology has been developed over the past 40 years for nuclear gaseous diffusion applications, and alumina and zirconia membranes have been used for the separation of uranium hexafluoride $\left(\mathrm{UF}_{6}\right)$ isotopes for the nuclear industry since 1950 (Krishnan et al., 1993). Current

\footnotetext{
${ }^{2}$ One micron $=10^{-6} \mathrm{~m}$.

${ }^{3}$ One $\mathrm{nm}=10^{-9} \mathrm{~m}$.
} 
DOE programs to develop ceramic membranes for coal-based applications are attempting to leverage this existing knowledge base. Investigators at the Oak Ridge Gaseous Diffusion Plant have produced alumina (ceramic) membranes with pore radii as small as $70 \mathrm{~nm}$. Membrane separation tests have demonstrated a capability to separate hydrogen from gas mixtures (DOE, 1992).

Membrane material research opportunities specific to coal-based systems involve primarily the development of inorganic membranes for separation of coal-derived products and impurities at elevated temperature and in corrosive environments. Improvements can be anticipated in the selectivity and separation efficiency based on enhanced understanding of the relationship between pore structure and the physical chemistry of molecular separations (NRC, 1993). Opportunities also exist for the development of membranes with improved resistance to the environments characteristic of coal-based systems, such that operating lifetimes can be extended. Given the likely increase in concerns over greenhouse gas emissions, the investigation and demonstration of cost-effective separation of methane from very dilute coalbed methane streams using membrane techniques also merit some attention.

\section{FINDINGS}

Future innovations in coal gasifier and combustor design will depend largely on an improved quantitative understanding of the interactions between coal ash, carbon oxidation, and emissions. The committee identified this topic as being of importance for DOE's coal-related advanced research activities, given its relevance to improved coal-based systems for power generation and fuel production.

Advanced research on coal liquefaction has the potential to achieve significant cost savings, either through improvements in current processing chemistry and technology or through processes based on new chemistries. There is currently very little industrial research on coal liquefaction; most activities are funded by DOE.

The operating environment in a coal-gas-fired turbine is more corrosive than that in a natural-gas-fired turbine, due primarily to the presence of sulfur and alkali metals. Evaluation of existing and emerging turbine material systems is needed to determine their suitability for advanced coal gasification-based power generation systems. This evaluation will require appropriate test rigs and methods for accelerated long-term testing in corrosive environments. Subsequent materials development will likely be necessary to optimize substrate and coating materials. The need for improved corrosion-resistant turbine materials is dependent on the ability of hot gas cleanup systems to reduce contaminant levels in coal-derived gas to acceptable levels for advanced gas turbines. The more successful the hot gas cleanup, the less demanding are the materials requirements, and vice versa.

The performance of high-temperature, high-pressure heat exchangers for EFCC power generation systems is currently limited by the properties of available materials. In particular, the maximum operating temperature of approximately $1090{ }^{\circ} \mathrm{C}\left[2000{ }^{\circ} \mathrm{F}\right]$ would not provide efficiencies significantly higher than state-of-the-art pulverized coal systems. The corrosive environment resulting from coal combustion imposes additional severe demands on materials. The ability to reach operating temperatures of $1370{ }^{\circ} \mathrm{C}$ to $1425{ }^{\circ} \mathrm{C}\left(2500{ }^{\circ} \mathrm{F}\right.$ to 
$2600^{\circ} \mathrm{F}$ )-corresponding to the inlet temperatures of future advanced gas turbines-represents a major materials challenge and is far from the current state of the art.

Inorganic membranes with high separation efficiencies and long-term resistance to hightemperature corrosive environments have the potential to improve the economics of power generation from coal, particularly for systems using advanced turbines. Materials development is required to improve the separation efficiency of ceramic membranes used for hot gas and flue gas cleanup. Improvements in durability at elevated temperatures in corrosive environments are also needed. Additional research opportunities exist to investigate membrane separation of methane from very dilute coalbed methane streams.

\section{REFERENCES}

Bannister, R.L., N.S. Cheruvu, D.A. Little, and C. McQuiggan. 1994. Turbines for the turn of the century. Mechanical Engineering 115(6): 68-75.

Bernstein, H.L., and J.H. Allen. 1992. A review of high temperature coatings for combustion turbine blades. Pp. 6.17-6.47 in Proceedings of the Steam and Combustion TurbineBlading Conference and Workshop, January 29-31, Orlando, Florida. Palo Alto, California: Electric Power Research Institute.

Burggraaf, A.J., K. Keiser, and B.A. van Heisel. 1989. Nanophase ceramics, membranes and ion implanted layers. Pp. 705-724 in Surface and Interfaces of Ceramics Materials. Dufour, L.C., Monty, and Petot-Evans, eds. Boston: Kluwer Academic Publishers.

Davis, K.A., R.H. Hurt, N.Y.C. Yang, and T.H. Headley. In press. Evolution of char density crystallinity and ultra fine structure during pulverized coal combustion. Pittsburgh, Pennsylvania: The Combustion Institute.

DeLuchi, M.A. 1993. Emissions of Greenhouse Gases from the Use of Transportation Fuels and Electricity. Argonne National Laboratory, ANL/ESD/TM-22. Washington, D.C.: U.S. Government Printing Office.

DOE. 1992. Advanced Research Program Plan: Crosscutting Fossil Fuels Science and Technology. U.S. Department of Energy, DOE/FE-0250T. Washington, D.C.: DOE.

DOE. 1993. Assessment of the Potential for Refinery Applications of Inorganic Membrane Technology-An Identification and Screening Analysis. U.S. Department of Energy, DOE/FE-61680-H3. Washington, D.C.: DOE

DOE. 1994a. Strategic Plan: Fueling a Competitive Economy, U.S. Department of Energy, DOE/S-0108. Washington, D.C.: DOE. 
DOE. 1994b. Fossil Energy Advanced Research: Strategic Plan, Review Draft, July 15. Washington, D.C.: DOE.

DOE. 1994c. FY 1995 Congressional Budget Request. U.S. Department of Energy, DOE/CR0023, Vol. 4. Washington, D.C.: DOE.

Krishnan, G.N., A. Sanjurjo, and B.J. Wood. 1993. Thermal/chemical degradation of inorganic membrane materials. Pp. 211-219 in Proceedings of the Coal-Fired Power Systems 93-Advances in IGCC and PFBC Review Meeting held June 28-30, 1993, Morgantown Energy Technology Center, Morgantown, West Virginia. U.S. Department of Energy, DOE/METC-93/6131. Washington, D.C.: DOE.

LaHaye, P.G., and M.R. Bary. 1994. Externally Fired Combustion Cycle (EFCC): A DOE Clean Coal V Project-Effective Means of Rejuvenation for Older Coal-Fired Stations. Paper presented at the ASME Turbo Expo '94, The Hague, Netherlands, June 13-16.

NRC. 1986. Materials for Large Land-Based Gas Turbines. National Materials Advisory Board, National Research Council. Washington, D.C.: National Academy Press.

NRC. 1993. Advanced Exploratory Research Directions for Extraction and Processing of Oil and Gas. Board on Chemical Science and Technology, National Research Council. Washington, D.C.: National Academy Press.

Orozco, N.J. 1993. High Pressure Ceramic Air Heater for Indirectly Fired Gas Turbine Applications. Paper presented at the Joint Contractors Review Meeting, FE/EE Advanced Turbine Systems Conference, FE Fuel Cells and Coal-Fired Heat Engines Conference, U.S. Department of Energy, Morgantown Energy Technology Center, Morgantown, West Virginia, August 3-5.

Orozco, N.J., and C.L. Vandervort. 1993. Ceramic Air Heater for an Indirectly Fired Gas Turbine Using Low Rank Fuels. Paper presented at the Low Rank Fuels Symposium, St. Louis, Missouri, May 11-12.

OTA. 1988. Advanced Materials by Design. U.S. Congress, Office of Technology Assessment, OTA-E-351. Washington, D.C.: U.S. Government Printing Office.

The Combustion Institute. In press. Proceedings of the 25th International Symposium on Combustion, July 1994, in Irvine, California. Pittsburgh, Pennsylvania: The Combustion Institute.

Vandervort, C.L., M.R. Bary, L.E. Stoddard, and S.T. Higgins. 1993. Externally Fired Combined Cycle Repowering of Existing Steam Plants. Paper presented at the Meeting of the International Gas Turbine Institute, Cincinnati, Ohio, May 24-25. 
Table 9-1 Trends in Advanced Research Budgets (millions of current dollars)

\begin{tabular}{lcccccccc}
\hline & FY & FY & FY & FY & FY & FY & FY & FY 1995 \\
Area & 1988 & 1989 & 1990 & 1991 & 1992 & 1993 & 1994 & (request) \\
\hline AR\&TD (research) & 21.1 & 20.2 & 21.2 & 22.9 & 23.0 & 20.4 & 22.6 & 19.8 \\
AR\&ET (fuels) & 6.1 & 6.9 & 6.8 & 8.1 & 7.1 & 7.4 & 5.2 & 0.8 \\
$\begin{array}{l}\text { AR\&ET (power } \\
\text { systems) }\end{array}$ & 8.1 & 7.4 & 7.1 & 8.2 & 7.3 & 2.9 & 2.1 & 1.8 \\
Total $^{2}$ & & & & & & & & \\
& 35.3 & 34.5 & 35.1 & 39.2 & 37.4 & 30.7 & 29.9 & 22.4 \\
& $(41.1)$ & $(38.5)$ & $(37.5)$ & $(40.3)$ & $(37.4)$ & $(29.9)$ & $(28.4)$ & $(20.7)$ \\
\hline
\end{tabular}

aFigures in parentheses represent total budget in constant 1992 dollars.

Source: Personal communication from David Beecy, U.S. DOE, to Jill Wilson, National Research Council, July 20, 1994. 
Table 9-2 Advanced Research Budgets for FY 1994 and FY 1995 (millions of current dollars)

\begin{tabular}{|c|c|c|}
\hline Area & FY 1994 (enacted) & FY' 1995 (requested) \\
\hline \multicolumn{3}{|l|}{ AR\&TD } \\
\hline Coal Utilization Science & 3.1 & 3.1 \\
\hline Materials & 8.9 & 6.9 \\
\hline Components & 1.7 & 0.9 \\
\hline Bioprocessing of Coal & 1.9 & 1.9 \\
\hline $\begin{array}{l}\text { University and National Laboratory Coal } \\
\text { Research plus University Coal Research }\end{array}$ & 5.0 & 5.0 \\
\hline HBCUs, ${ }^{a}$ Education, and Training & 1.0 & 1.0 \\
\hline Instrumentation and Diagnostics & 1.0 & 1.0 \\
\hline Subtotal (AR\&TD) & 22.6 & 19.8 \\
\hline \multicolumn{3}{|l|}{ AR\&ET } \\
\hline \multicolumn{3}{|l|}{ Advanced Clean Fuels Research } \\
\hline Coal Liquefaction & 5.2 & 0.8 \\
\hline \multicolumn{3}{|l|}{ Advanced Clean/Efficient Power Systems } \\
\hline Combustion Systems & 0.5 & 0.4 \\
\hline Control Technology and Coal Preparation & 1.1 & 1.0 \\
\hline Surface Coal Gasification & 0.5 & 0.4 \\
\hline Subtotal (AR\&ET) & 7.3 & 2.6 \\
\hline TOTAL & 29.9 & 22.4 \\
\hline
\end{tabular}

${ }^{2}$ Historically black colleges and universities.

Source: DOE (1994c). 
PART III

RECOMMENDATIONS FOR DOE'S FUTURE COAL PROGRAM 


\section{Conclusions and Recommendations}

This chapter synthesizes the discussions and findings of Part II (chapters 5-9) in the context of the committee's charge and the strategic planning framework and background presented in Part I (chapters 1-4). For each topic discussed in chapters 4 through 9, conclusions and recommendations are offered below. ${ }^{1}$ The cross-cutting systems analysis area not explicitly covered in chapters 4 through 9 is addressed separately. In the final section of the chapter, the committee's conclusions and recommendations are interpreted in the context of the individual sections of the EPACT that relate to coal (see Chapter 1 and Appendix B).

\section{STRATEGIC PLANNING FOR COAL}

In Chapter 4 a strategic planning framework was established to assess planning for coalrelated RDD\&C. The framework is based on projected scenarios for future energy demand and markets for coal technologies, taking into account likely future environmental requirements, competing energy sources, institutional issues, international activities, and other factors affecting the demand for coal. In the committee's view, the overall objective of DOE's coal program should be to provide the basis for technological solutions to likely future demands, as reflected in the scenarios. The committee defined three planning horizons-near-term (1995-2005), midterm (2006-2020), and long-term (2021-2040) periods-for which the scenarios were formulated and requirements for coal were outlined. Based on its analysis, the committee concluded that coal will continue to be a major energy source in the U.S. economy over all planning horizons considered and that a sustained program of RDD\&C for coal technologies is important for the economic, environmental, and security interests of the United States.

The strategic planning framework identified two priority areas for the DOE coal program: (1) conversion of coal to electricity, representing the principal market for coal for all planning periods, but particularly in the mid- to long-term periods; and (2) conversion of coal to liquid and low- and medium-Btu gaseous fuels, in the mid to long term. EPACT requirements for coal use emphasize the need for high efficiency, low environmental impacts, and competitive costs. These needs are generally consistent with DOE's objectives for coal RDD\&C, as defined in the

\footnotetext{
${ }^{1}$ Asterisks $\left(^{*}\right)$ identify the most important recommendations.
} 
most recent planning documents (DOE, 1993a, 1994a). The DOE planning horizon, however, currently extends only to 2010. Specific objectives have been formulated for that period for advanced power systems and advanced fuel systems. These objectives are discussed below in the sections on electric power generation and clean fuels from coal.

\section{Conclusions}

1. DOE's strategic planning objectives for coal technology RDD\&C currently extend only through the year 2010 , even though coal will continue to be a major source of energy well beyond that period.

2. The most important strategic objectives for coal RDD\&C programs are to support the development of (a) advanced coal-based electric power systems that are considerably more efficient and cleaner than current commercial systems and which will be needed beginning in the near to mid term; and (b) advanced coal-based fuel and coproduct systems that can be used to replace conventional oil and gas in the mid- to long-term periods.

\section{Recommendations $^{2}$}

1. *The planning horizon for DOE coal RDD\&C programs should extend beyond the agency's current planning horizon of 2010. The committee recommends the use of three time periods for strategic planning: near term (1995-2005), mid term (2006-2020), and long term (2021-2040). The main objective of DOE's coal program in all periods should be to provide the basis for technological solutions to likely future demands in a way that is robust and flexible.

\section{COAL PREPARATION, COAL-LIQUID MIXTURES, AND COALBED METHANE RECOVERY}

Coal preparation-or cleaning-is a widely used commercial process for removing mineral matter from as-mined coal to produce a higher-quality product. Current physical cleaning processes are used primarily to reduce the ash content of as-delivered coal, although some sulfur reduction (typically 20 to 30 percent) is also achievable in coals with high pyrite content. Because coal is an abundant and relatively low cost fuel, the incremental cost of coal cleaning is a major factor limiting the degree of impurity reductions that are economically feasible.

DOE research in recent years has focused on advanced processes to clean fine coal fractions to achieve a relatively low ash, low-sulfur product suitable primarily for premium applications, such as the production of coal-liquid mixtures that can be substituted for petroleumbased fuels. More recently, attention has also focused on the potential for coal cleaning to

\footnotetext{
${ }^{2}$ Asterisks (*) identify the most important recommendations.
} 
remove trace species as a means of reducing power plant emissions of air toxics. A series of RD\&D goals has been defined (DOE, 1993a).

Coal-liquid mixtures or slurries-primarily coal-oil and coal-water fuels-are another commercial technology that allows coal to be substituted for liquid fuels in combustion applications. R\&D in this area peaked during the late 1970 s and early 1980 s when oil prices were high and coal-based substitutes were attractive. Commercial interest waned, however, as oil prices declined and oil price projections remained stable. Nonetheless, DOE has continued to fund basic and applied research related to CWSs (coal-water slurries), primarily at universities.

Finally, interest in recovery of coalbed methane has been stimulated by concern about greenhouse gases and EPACT requirements. Methane recovery technology for high methane concentrations is commercially available, and recovery is practiced by the gas and coal mining industries where local conditions justify the investment. However, systems for the capture and use of dilute coalbed methane streams, which are found in many coal mining operations, are not sufficiently mature for commercial implementation. As noted in Chapter 3, increased efforts will likely be needed to reduce coalbed methane released from underground mining, in accordance with the Climate Change Action Plan (Clinton and Gore, 1993). The research challenge is to economically recover coalbed methane from very dilute gas streams.

\section{Conclusions}

1. Coal preparation is a highly developed, commercially available technology that is widely used in the coal industry but that offers only limited opportunities for R\&D to significantly lower the cost of advanced coal preparation processes. Continued research with extensive industry participation should achieve further improvements in existing and emerging technologies.

2. There may be opportunities through sustained fundamental research on cleaning processes to improve the environmental acceptability of coal.

3. Given the mature status of technologies for the production and use of coal-liquid mixtures and the very limited market for these mixtures, no further development by DOE appears necessary.

4. Although the collection and use of concentrated coalbed methane streams are not widely practiced in the coal mining industry, relevant technologies are available for commercial application.

5. Additional reductions in emissions of coalbed methane could be achieved through the development of technologies for the capture and use, or destruction, of dilute coalbed methane streams. 


\section{Recommendations}

1. Strategic planning goals for the performance and cost of coal cleaning processes should define clearly the supporting role of coal preparation in DOE's programs in advanced power generation and fuels production, thereby focusing $R \& D$ activities.

2. DOE should phase out program activities related to coal-liquid mixtures.

3. DOE should implement a technology R\&D program that addresses the control and use of dilute coalbed methane gas streams in response to EPACT requirements.

\section{ELECTRIC POWER GENERATION}

\section{Power Generation Systems}

The availability of high-performance gas turbines and low-cost natural gas has resulted in the use of natural-gas-fired combustion turbines for many recently installed power generation facilities. As discussed in chapters 3 and 4, decreasing availability and higher costs for natural gas in the next decade and beyond are expected to result in a resurgence of construction and repowering of coal-based power generation facilities, with requirements for greatly improved emission controls and higher efficiency. Substantial improvements over past practices are technically possible. A large fraction of DOE RDD\&C on power generation is devoted to systems designed to meet anticipated emission control and efficiency requirements.

The advanced coal-based power generation systems under development with DOE funding can be divided into three groups based on projected efficiency: ${ }^{3}$

- Group 1-approximately 40 percent efficiency-includes the low-emission boiler system (LEBS), first-generation PFBC (PFBC-1), and first-generation IGCC (IGCC-1).

- Group 2-approximately 45 percent efficiency-includes EFCC, second-generation PFBC (PFBC-2), and second-generation IGCC (IGCC-2).

- Group 3-50 to 60 percent or greater efficiency-includes HIPPS, improved secondgeneration PFBC (improved PFBC-2), integrated gasification advanced-cycle (IGAC), and IGFC.

Important features of these systems are summarized in Table 10-1. Information on stateof-the-art commercial pulverized coal systems is included in the table as a baseline. Current DOE funding levels for these various technologies were summarized in Chapters 2 and 7.

\section{Efficiency and Cost Targets}

As shown in Table 10-1, DOE's efficiency goals for advanced power systems rise to 60 percent for the year 2010 (best current new plant levels are about 38 percent for the United States and 42 percent worldwide). In the DOE plan the highest efficiencies are expected to be

${ }^{3}$ For definitions of thermal efficiency, see Glossary. 
achieved with IGFC technology (DOE, 1993a). A number of other systems are projected to achieve efficiencies of 45 to 55 percent using advanced combustion and gasification-based approaches and high-performance gas turbines. A major objective of the DOE plan is to achieve these higher efficiencies at an overall cost of electricity that is 10 to 20 percent lower than that of today's coal-fired power plants while also meeting more stringent environmental requirements (see Table 10-2). ${ }^{4}$

In the view of the committee, the DOE efficiency goals, especially for the later years, are quite optimistic. For example, the efficiency goals of 55 percent for systems using $1290{ }^{\circ} \mathrm{C}$ $\left(2350^{\circ} \mathrm{F}\right)$ gas turbine topping cycles exceed the performance capabilities of about 50 percent efficiency for current combined-cycle systems using natural gas. While turbine improvements are expected to raise the efficiency on natural gas to about 57 percent (see Chapter 7), coal gasification and gas cleanup energy losses will decrease efficiency by five to 10 efficiency points when using the gasification systems being demonstrated in the CCT program (see Chapter 6). Thus, substantial reduction of gasification-related losses is needed to achieve the DOE target system efficiency with IGCC. As noted in Chapter 7, the hybrid second-generation pressurized fluidized-bed combustion system, which gasifies only part of the coal, is estimated to have a potential for approximately four percentage points higher efficiency than IGCC systems where all the coal is gasified (Maude, 1993). Conceivably, this system could achieve the DOE efficiency goal; however, substantial technical hurdles remain to be overcome. Similar comments apply to the 60 percent efficiency goal for IGFC systems.

The goal of 10 to 20 percent reduction in the cost of power, concurrent with significant efficiency increases and emissions reductions, may be especially difficult to realize. For example, roughly 30 percent of the cost of electricity today for a new coal-fired plant represents the cost of fuel (EPRI, 1993). Thus, reducing fuel requirements by one-third by raising plant efficiency from about 40 to 60 percent would lower the overall electricity cost by about 10 percent, which is DOE's minimum cost reduction objective. A smaller efficiency gain would yield still smaller cost savings. These estimates assume that the nonfuel costs-principally the initial capital cost-remain constant. DOE targets show lower capital costs for advanced technologies than current commercial systems. More likely, the capital cost of more efficient combined-cycle systems will exceed that of the simpler, less demanding technologies now in use (Merrow et al., 1981). Higher capital and operating costs would mean that overall reductions in the cost of electricity would be difficult or impossible to achieve.

While projections of the cost and performance of new technologies are subject to great uncertainty (Frey et al., 1994), comparison of systems and options should be done on a common and clearly stated basis to provide valuable guidance for investment in RDD\&C (see below, Systems Analysis and Strategy Studies). Such comparative studies are extremely valuable for assessing the validity of program goals and for communication of results.

A more realistic cost goal for the DOE advanced power systems program might be to achieve efficiency improvements at an overall electricity cost comparable to that for new coal plants today. For the future U.S. market, some cost premium could even be acceptable if justified by the improved environmental performance and reduced externality costs associated with advanced technologies. Indeed, future environmental regulations may well require such

${ }^{4}$ Identical to Table 2-3. 
higher performance, creating new incentives for investment in higher-efficiency systems. To be competitive overseas, advanced technologies would require the lowest possible capital costs consistent with the environmental and other requirements of specific foreign markets. In short, despite DOE's current planning estimates, it remains to be seen whether high performance and smaller investment costs are in fact compatible objectives.

\section{Group 1 Systems}

Group 1 power generation systems generally make use of commercially available components and technologies, such as supercritical boilers, gasifiers, and cold gas cleanup systems. Only limited use of first-generation PFBC and IGCC systems is expected in the United States. Demonstration programs for these technologies are under way both in the United States and abroad, and the main incentive to continue the domestic activity is to develop a foundation for second- and third-generation systems. On the other hand, the LEBS technology program outlined by DOE (1993a) does not appear to offer opportunities for development of a substantially more efficient, lower- emission system. Only if LEBS achieves a significantly lower cost than existing systems with comparable performance would its development be justified for near-term markets.

Assuming that Group 1 performance and cost objectives can be met, the market for Group 1 technologies will probably be limited to near-term installations where there is no economic penalty for carbon dioxide $\left(\mathrm{CO}_{2}\right)$ emissions. Although the committee's baseline scenarios assume no such penalties for the near term (1995-2005), it envisions new regulations or penalties aimed at forcing $\mathrm{CO}_{2}$ reductions during the mid-term period (2006-2020). Technologies in Group 1, with their limited efficiency improvements over existing plants, would be at a disadvantage relative to the newer Group 2 systems emerging in the mid-term period. The "less demanding" scenario discussed in Chapter 4 assumes that economic penalties on $\mathrm{CO}_{2}$ emissions might not be imposed for the foreseeable future. This might well be the case in developing countries such as China, and Group 1 technologies might therefore be of potential export interest.

\section{Group 2 and 3 Systems}

In contrast to Group 1 systems, technologies in groups 2 and 3 are judged by the committee to have greater potential to meet future power generation and associated environmental requirements: all technologies in these two groups make use of advanced components to achieve higher efficiencies and lower emissions. Major questions of system integration and reliability will need to be addressed, and early pioneer installations could serve as a basis for improved systems.

The riskiest components appear to be the high-temperature heat exchanger and furnace required for the indirectly fired systems, and the hot gas cleanup systems for the advanced PFBC and gasification-based systems. It is not established that high-temperature gas turbines can tolerate the chlorine and alkali metals that may be present in FBC (fluidized-bed combustion) 
products or the sulfur and particulates in the gasifier products of IGCC systems. Although hot gas cleanup is a component of advanced IGCC systems, cold gas cleanup could still allow the technology to succeed, if at a lower efficiency. In this sense, IGCC is a somewhat less risky technology than PFBC.

The $1370^{\circ} \mathrm{C}$ to $1425^{\circ} \mathrm{C}\left(2500^{\circ} \mathrm{F}\right.$ to $\left.2600^{\circ} \mathrm{F}\right)$ gas turbine required for Group 3 systems is within the state of the art for aviation systems but is still under development for electric power generation systems and will require demonstration and testing. The IGCC-2 and IGAC systems with an advanced gas turbine may not be significantly more expensive than first-generation systems if the turbine development effort is successfill.

As noted previously, integrated gasification fuel cell systems offer the highest efficiencies and emission controls. Systems using molten carbonate or solid oxide fuel cells incorporate a steam bottoming cycle to maximize efficiency. Molten carbonate and solid oxide fuel cells operate at high temperatures $\left(650^{\circ} \mathrm{C}\left[1200^{\circ} \mathrm{F}\right]\right.$ and $980^{\circ} \mathrm{C}\left[1800^{\circ} \mathrm{F}\right]$, respectively). Since the maximum voltage produced by a fuel cell decreases with increasing temperature, the highertemperature solid oxide fuel cell produces a smaller fraction of the total system power. However, the potentially lower costs of the solid oxide fuel cell provide incentives for continued research on these systems. The potential market for fuel cell technologies is quite large, especially for distributed power generation. However, fuel cell systems may still not be cost competitive with gas turbine systems without environmental incentives for higher efficiencies.

Gas turbine and fuel cell activities are currently funded under the natural gas portion of DOE's FE R\&D program. However, gas turbines and fuel cells could be used with coal-derived gas, with the addition of gasification and gas cleanup facilities. The principal operating difference between natural gas and coal-derived fuel gas in these applications relates to the contaminants in coal-derived gas. Cold gas cleanup is capable of removing contaminants to a negligible level; however, there is an efficiency penalty of about two percentage points, along with the production of liquid waste streams that must be treated, adding to system complexity and cost. Hot gas cleanup is potentially more efficient but at the expense of less complete removal of contaminants, especially volatilized species that are not captured in current hot gas cleanup designs.

The requirements for cleanup of coal-derived fuel gas are expected to differ for fuel cell and gas turbine systems. System optimization will be required and needs to be established as part of the DOE coal program. For the molten carbonate fuel cell, ammonia, hydrogen sulfide, chlorine compounds, trace metals, and particulates would interact with the electrodes and with the carbonate electrolyte, necessitating electrolyte replacement and disposal of resulting watersoluble solid waste. For high-temperature gas turbines, damage to the blades is of greatest concern, and a discussion of research aimed at mitigating this concern can be found in Chapter 9 (Advanced Research Programs). Degradation caused by contaminants would limit maximum turbine inlet temperature, thereby limiting attainable system efficiency.

Thus, for fuel cell systems, the major development challenge is to reduce both fuel cell costs and balance-of-plant costs. For gas turbines, the major goal is to maximize turbine inlet temperature. Increasing turbine inlet temperature from the current maximum of $1290{ }^{\circ} \mathrm{C}$ $\left(2350{ }^{\circ} \mathrm{F}\right)$, beyond the $1370^{\circ} \mathrm{C}$ to $1425^{\circ} \mathrm{C}\left(2500{ }^{\circ} \mathrm{F}\right.$ to $\left.2600{ }^{\circ} \mathrm{F}\right)$ proposed for integrated gasification advanced-cycle systems, to the $1540^{\circ} \mathrm{C}$ to $1650^{\circ} \mathrm{C}\left(2800^{\circ} \mathrm{F}\right.$ to $\left.3000^{\circ} \mathrm{F}\right)$ used in high-performance turbines would bring system efficiencies to a level approaching that expected 
for molten carbonate fuel cells. These major development goals for fuel cells and gas turbines apply to systems fueled with either natural gas or coal-generated gas. No special considerations for coal-derived fuel gas appear necessary at this time, beyond those described above for the coal program.

To use coal, both fuel cell and gas turbine systems depend on coal gasification technology; both can accept methane and light hydrocarbons in the fuel gas. As discussed in Chapter 6, coal gasification results in a loss of five to 10 percentage points in overall power generation efficiency compared to natural gas. Development of maximally efficient gasification technology is thus essential for future high-efficiency utilization of coal for both fuel cell and gas turbine systems.

\section{Magnetohydrodynamics}

The use of topping cycles-as in fuel cells, gas turbines, and MHD generators-to achieve efficiencies higher than those attainable in the simple steam Rankine cycle (approximately 42 percent) has been adopted worldwide and is the major focus of the ongoing DOE program on advanced technologies for electricity generation. Advances in gas turbine and fuel cell technologies have essentially closed the original efficiency gap that stimulated a large worldwide effort on MHD during the 1960s and 1970s. Over the past decade, this MHD effort has been greatly reduced. Within the DOE FE Advanced Clean/Efficient Power Systems Program, no further funds are allocated for MHD, except for closeout of the proof-of-concept study. EPACT Section 1311 recommends (and the committee concurs) that an integrated documentation of the results of the extensive proof-of-concept work should be prepared, to capture the "lessons learned" and to establish a reference point for any possible development of MHD systems in the future.

\section{Emissions Control Technologies}

Environmental control requirements for coal-based power plants are expected to become increasingly stringent in response to more demanding federal, state, and local requirements. In the near term, new control requirements for nitrogen oxides $\left(\mathrm{NO}_{x}\right)$ and air toxics are anticipated, along with new ambient standards for fine particulates. Over the longer term, significant reductions in $\mathrm{CO}_{2}$ and solid wastes may be needed.

\section{Targets}

DOE's strategic objectives for conventional air pollutants $\left(\mathrm{SO}_{2}, \mathrm{NO}_{x}\right.$, and particulates) express future goals relative to the 1979 federal New Source Performance Standards (NSPS) for coal-fired power plants (see Table 10-2). These emissions goals apply to advanced power systems in Groups 2 and 3. DOE's goals for 2000 and 2005 can already be met or exceeded by technology in commercial use today, although cost reduction remains an important objective. 
Because environmental control requirements show a strong tendency to become more stringent, and because DOE's emissions goals for the next decacle already are being achieved with modern technology (see Chapter 3), it is not clear to the commaittee that the DOE goals will be adequate to meet all necessary environmental standards for coal plants a decade or more from now. The 2010 target of $1 / 10$ NSPS represents a relatively demanding level of emissions reduction but one that should be achievable by a number of coal-based systems much sooner than 2010 (although not all advanced systems may be able to meet the objective readily for all pollutants). Whether DOE's emission goals will be adequate to meet regional and local environmental quality constraints-which tend to be the most demanding-cannot be foreseen.

Emissions control requirements for hazardous air pollutants (air toxics) have yet to be defined by the EPA (U.S. Environmental Protection Agency). The most likely need in this area will be for control of volatile species, such as mercury, which escape collection in existing gas cleaning systems. Studies are in progress to assess baseline emission levels for current and advanced technologies.

In the mid- to long-term periods a critical environmental issue for coal use is likely to be the need to reduce emissions of $\mathrm{CO}_{2}$ and other greenhouse gases. The committee concurs with DOE's primary strategy of reducing coal-related $\mathrm{CO}_{2}$ emissions by improving the energy efficiency of new power generating plants. The $\mathrm{CO}_{2}$ benefits of advanced technologies should be compared to the best commercial technologies currently available, which are more efficient than average U.S. plants (Table 10-3). The reductions actually achieved in the U.S. economy will depend on the rate of penetration of the advanced technology.

The DOE program plan includes the cross-cutting area of control technology, whose general goal is to achieve "ultra-low" emissions beyond the goals for 2010 (DOE, 1993a). No specific targets are set. However, the historical evidence (Appendix D) shows a strong trend toward requiring emissions from new coal plants to be reduced to the maximum extent achievable, within reasonable constraints on economic cost. Ideally, a risk-cost-benefit analysis would serve as the basis for determining environmental control regulations; discussion of this topic is beyond the scope of the present study. A possible vision for longer-term environmental R\&D goals is to benchmark emissions of air pollutants from coal plants relative to cleaner but more costly competing fuels, particularly natural gas. With the exception of $\mathrm{CO}_{2}$ content, it is feasible to match the quality of natural gas by cleanup of coal-derived gas. Since natural gas will continue to be used, a consistent set of requirements for coal-derived gas and natural gas may be appropriate. To the extent that such a goal for ultra-low emissions can be achieved, the environmental acceptability of coal relative to competing energy sources will be enhanced. The long-term challenge for the DOE program, then, would be to develop systems that achieve targeted emissions reductions from coal plants at reasonable cost. If this long-term goal can be achieved, the primary environmental concern remaining for coal-based systems, aside from $\mathrm{CO}_{2}$ emissions, will be solid wastes.

The increasing cost and decreasing availability of landfill disposal options, particularly near urban and suburban population centers, will require increased attention to waste minimization, recycle, and reuse methods. In the committee's opinion, DOE's goal of reducing solid wastes from advanced pulverized-coal systems by half appears to be reasonable for nearto mid-term technologies (DOE, 1993a). More ambitious goals than the targeted 50 percent 
waste utilization from advanced power systems by 2010 are appropriate for the long term, when higher waste disposal costs will provide greater incentives for waste reduction at the source.

\section{Technology Development Needs}

A number of technologies now being demonstrated in the CCT program offer potentially lower emissions control costs in the near term for conventional air pollutants, for both new and retrofit plants. The most challenging problem for DOE is to achieve reliable and cost-effective emissions control using hot gas cleanup for advanced power systems. The most critical need is for high-temperature, high-pressure particulate removal. This technology is essential for the advanced PFBC systems; it is one way to achieve higher efficiencies with advanced IGCC systems. Hot gas desulfurization technology similarly remains to be developed for advanced IGCC systems. While current hot gas cleanup devices achieve very low levels of $\mathrm{SO}_{2}$ and particulate emissions, to date neither hot gas particulate removal nor hot gas desulfurization systems have approached the durability and reliability requirements needed for a commercial system. Furthermore, current hot gas cleanup systems do not control volatile air toxics or nitrogen oxides $\left(\mathrm{NO}_{x}\right)$. DOE remains optimistic that these critical problems will be solved through continued $R \& D$. Nonetheless, the promise of advanced PFBC and the potential efficiency gains of IGCC and IGFC systems will not be realized until significant progress is demonstrated. For gasification-based systems, existing or improved cold gas cleanup systems can meet anticipated environmental requirements but at an efficiency penalty of about two percentage points.

To achieve larger or more rapid reductions in $\mathrm{CO}_{2}$ emissions than can be achieved by improving the thermal efficiency of coal-based power plants, technological options for the removal and storage of $\mathrm{CO}_{2}$ from conventional and advanced power systems could also be needed. The current DOE plan provides for such a contingency, in its objective of demonstrating by 2010 the capability to reduce and sequester $\mathrm{CO}_{2}$ emissions by about 80 percent at a cost premium of not more than 20 percent (DOE, 1993a). Given the current state of technology in this area, the most pressing need is for research related to $\mathrm{CO}_{2}$ storage.

One of the most demanding long-term technical challenges for the DOE coal program is the reduction or elimination of solid wastes-a major environmental concern-through innovative and cost-effective recycle and reuse options, perhaps as part of an integrated "coal refinery."5 At present, DOE has only a relatively small program ( $\$ 2.4$ million per year) in solid waste management. At least one of DOE's advanced coal technologies-the second-generation PFBC system-generates more solid waste than today's best commercial plants meeting stringent standards for $\mathrm{SO}_{2}$ removal (98 percent or more). This underscores the need to find effective solutions that will allow coal to compete environmentally with alternative fuels for power generation.

\footnotetext{
${ }^{5}$ The term "coal refinery" is understood as a system consisting of one or more individual processes integrated so as to allow coal to be processed into two or more products supplying two or more markets.
} 


\section{Conclusions}

\section{Power Generation Systems}

1. DOE's selection of efficiency, emissions, and cost as key attributes of advanced coalbased technology is appropriate for strategic planning. However, its specific efficiency and cost objectives for advanced power systems appear to be overly optimistic given the current state of technology. On the other hand, DOE's power plant emission goals appear to be insufficiently challenging relative to the capabilities of current commercial technology and the environmental demands expected on future coal use.

2. The market for Group 1 systems (LEBS, PFBC-1, and IGCC-1, with approximately 40 to 42 percent efficiency) will probably be small in the United States. The overseas market may offer the best opportunities for commercialization. In particular, because LEBS offers comparatively small potential to evolve to a significantly higher performance system, it will be attractive only if it achieves a significant cost reduction relative to current commercial systems with comparable performance.

3. For group 2 and 3 systems with 45 to 60 percent targeted efficiency, new technological achievements are required to achieve the goals defined by DOE, including development of high-temperature gas turbines, high-temperature heat exchangers, hot gas cleanup systems, and advanced fuel cells.

4. Overall, gasification-based systems offer the lowest risk and highest potential for lower emissions and higher efficiency than current technology, but cost expectations need to be more clearly defined.

5. System optimization cost and market studies are needed to define the roles and relative merits of the systems now being funded.

6. While most of the DOE gas turbine program is funded under the DOE natural gas budget, the future of many of the high-efficiency options for efficient coal use depends on firing these same turbines with gas from coal gasification or pressurized fluidized-bed combustion.

7. The gas turbine program under the DOE coal budget is appropriately focused on assessing the problem of trace material contamination (e.g., alkali metals) and possible solutions, such as special turbine materials, especially when hot gas cleanup is used.

8. The integrated gasification fuel cell system offers the highest efficiency and lowest emissions of power generation systems under development within the DOE program. However, high fuel cell cost may be a significant barrier to widespread use, and a carefully documented projection of the potential for cost reduction is needed to establish program priorities.

9. The highest efficiency for IGFC systems will be obtained with hot gas cleanup; however, the requirements for contaminant removal need to be established.

10. The molten carbonate fuel cell offers the most promise among the current fuel cell options for IGFC power generation systems.

11. Overall, current DOE priorities as reflected in the FY 1994 budget authorization and the FY 1995 budget request for advanced power systems-including the fuel cell and gas turbine components of the natural gas program-are consistent with the committee's view of priorities across different power generating options. 


\section{Emissions Control Technologies}

12. Overall, DOE can make an important contribution to reducing the costs and improving the performance of emissions control technologies by careful selection of critical problems for research in conjunction with industry.

13. Hot gas particulate cleanup is an especially critical technology at this time, since it will be an essential element in the success of high-performance PFBC and could improve the efficiency of gasification-based systems.

14. Hot gas cleanup for sulfur removal is another critical development needed for advanced PFBC systems where high-efficiency sulfur removal still needs to be demonstrated at acceptable reagent stoichiometries. There would also be efficiency benefits for advanced IGCC systems.

15. A thorough understanding is needed of options for the control of hazardous air pollutants, especially volatile air toxics, such as mercury and chlorine, across the set of advanced combustion and gasification-based technologies.

16. $\mathrm{NO}_{x}$ control measures meeting DOE's performance targets for advanced power systems with hot gas cleanup and high-temperature turbines remain to be fully specified and demonstrated. Selective catalytic reduction or other add-on technologies could well be required in addition to the combustion-based $\mathrm{NO}_{\mathrm{x}}$ controls now envisioned.

17. Solid waste reduction is needed for all coal-based systems. Waste minimization, byproduct recovery, and reuse options will become increasingly important and merit additional attention.

18. Currently, the primary focus of DOE's coal R\&D to reduce $\mathrm{CO}_{2}$ emissions is improving power plant efficiency. Should future policy measures require an accelerated rate of $\mathrm{CO}_{2}$ reductions, additional measures to remove and dispose of $\mathrm{CO}_{2}$ from gas streams, to avoid $\mathrm{CO}_{2}$ emissions to the atmosphere, could also be warranted.

\section{Recommendations $^{6}$}

\section{Power Generation Systems}

1. DOE's quantitative performance and cost objectives for advanced power systems should be reviewed in light of the committee's discussion and conclusions. In particular, a more realistic goal for advanced power systems would be to achieve significant efficiency improvements at an overall cost comparable to new plants today. For environmental R\&D goals, an alternative long-term vision is to benchmark air emissions from coal plants relative to cleaner but more costly competing fuels, particularly natural gas. The long-term challenge would be to achieve greater emissions reductions economically while substantially reducing solid wastes.

2. Further development of LEBS should be predicated on at least 50 percent cost sharing with industry to demonstrate its potential to reduce costs below those of current systems with comparable performance.

\footnotetext{
${ }^{6}$ Asterisks $(*)$ identify the most important recommendations.
} 
3. *Future investment of DOE resources in first-generation systems should be based on realistic market expectations and value as an entry into new technology with high growth potential. At least 50 percent industry cost sharing should be required to demonstrate private sector confidence in these technologies.

4. *Second- and third-generation gasification-based systems should be given the highest priority for new plant applications. Work on all the advanced systems should focus on acquiring the cost, emissions control, and efficiency information needed to select the most promising systems for further development. The limitations of critical components, such as heat exchangers, turbines, and fuel cells, and the timing and probability of technological successes should be taken into account. This process should begin before FY 1996 and should include a rigorous comparative study of the design options.

5. The DOE coal program should focus on assessing and solving turbine life problems related to coal-generated trace materials. If limitations caused by trace components are identified, research on special control technologies and on alternative materials resistant to the effects of contaminants should be undertaken.

6. DOE should identify research priorities specific to the use of coal-derived gas in fuel cells, such as the effect of contaminants on fuel cell performance and emissions.

\section{Emissions Control Technologies ${ }^{7}$}

7. *A critical assessment of hot gas cleanup systems for advanced IGCC and PFBC should be undertaken immediately to determine the likely costs and the ability to meet, in the next three to five years, all requirements for future high-temperature $\left(>1260^{\circ} \mathrm{C}\left[>2300{ }^{\circ} \mathrm{F}\right]\right)$ turbine operation and environmental acceptability.

8. Research on control of volatile air toxics for advanced power systems should be initiated, with a priority on those substances that remain in a gaseous phase at typical exhaust gas temperatures (generally $>95^{\circ} \mathrm{C}\left[>200^{\circ} \mathrm{F}\right]$ ). Assessments of current capabilities to control other hazardous air pollutants should also be undertaken.

9. Research should be continued on innovative approaches for less costly and more effective control of sulfur and nitrogen emissions in both retrofit and new plant applications.

10. Reduction of solid waste emissions from coal use processes should be given a higher priority in the DOE research program, with emphasis on innovative and lower-cost by-product recovery and reuse. An evaluation of by-product disposal and reuse options and costs should be conducted for all DOE-funded coal programs.

11. In addition to emphasis on efficiency improvements, continued R\&D on the most promising retrofit measures for $\mathrm{CO}_{2}$ capture and disposal is appropriate.

\footnotetext{
${ }^{7}$ Asterisks $(*)$ identify the most important recommendations.
} 


\section{CLEAN FUELS AND SPECIALTY PRODUCTS FROM COAL}

Clean gases and liquid products derived from coal have the potential for substantial future use. At present, natural gas and refined petroleum are much less costly than comparable products from coal. However, both of these resources are expected to become more costly (EIA, 1994).

DOE's primary strategic objective for advanced fuel systems is to demonstrate by 2010 advanced concepts for producing liquid fuels and other products from coal that can compete with products produced from petroleum, when petroleum prices are $\$ 25 / \mathrm{bbl}$ (1991 dollars) or greater. ${ }^{8}$ At this price, coal-derived liquids may become competitive with nonconventional oil sources, such as tar sands and shale, and may also compete with the higher worldwide oil prices projected for the mid to long term.

It is likely that national efforts to reduce ${ }^{\prime} \mathrm{CO}_{2}$ emissions, as well as other environmental legislation and regulatory actions, could lead to increased emphasis on improved efficiency for technologies that convert coal to gaseous and liquid fuels. However, the cost of coal alone is too low to justify large additional investments for efficiency improvement. To date, DOE has not adopted environmental emission goals for coal liquefaction process plants, as it has for electric power plants. Future plants will likely have to meet air, land, and water emission requirements that are more stringent than those in place today, which could increase the overall cost of coal conversion processes relative to processes that use oil or gas.

\section{Coal Gasification}

The conversion of coal to cleaned gas with current technology incurs a loss of the inherent useful energy in the coal of approximately 20 percent, corresponding to an efficiency loss of 10 percentage points in IGCC systems using coal-derived gas (see Chapter 6). This loss can be largely attributed to temperature cycling and increased energy requirements for compression. Commercial high-temperature, oxygen-blown, entrained-flow systems with cold gas cleanup would have a loss of around 13 percentage points. The committee believes that further improvements in gasification technology are quite feasible and that cooperative programs with industry could help identify opportunities to improve both fluidized-bed and moving fixedbed systems, leading to increased efficiency of advanced power generation systems.

For coproduct systems producing clean fuels and electricity, requirements for maximizing system efficiency are much alike. However, air-blown systems would be at a disadvantage. If oxygen systems are used, minimized oxygen consumption is important, and low-temperature gasification with methane production would require less heat and therefore less oxygen. Catalytic fluidized-bed systems offer potential for this application and have been studied in the past, but no currently active programs have been identified by the committee.

\footnotetext{
${ }^{8}$ The committee notes that DOE's costing method employs assumptions common among electric utilities but not among oil companies. In particular, the interest rates assumed in amortizing the capital cost of a liquefaction plant are based on a lower assumed risk and therefore lower rates of return than are commonly used by the petroleum industry (see Chapter 2 and Glossary). This difference in required rate of return will result in higher costs compared to DOE estimates (DOE, 1993b).
} 
The ongoing CCT program includes demonstration of six commercial gasification technologies. In addition, the proposed FY $1995 \mathrm{FE}$ coal R\&D program budget for Advanced Clean/Efficient Power Systems includes significant funding for construction of an advanced airblown, moving fixed-bed gasifier, which has the potential to meet the IGCC-2 efficiency goal of 45 percent and minimize production of coal tar. However, since air rather than oxygen is used, this system would not be well suited for the production of clean fuels requiring hydrogen or syngas. A significant reduction in the DOE budget for advanced gasification research has been proposed for FY 1995 (see Chapter 6), despite the needs and research opportunities for improved gasification efficiency for both power generation and clean fuels production.

\section{Products from Coal-Derived Gas}

\section{Hydrogen Production}

Production of pure hydrogen from fossil fuels involves oxidation and separation, together with conversion of $\mathrm{CO}$ and water to $\mathrm{H}_{2}$ and $\mathrm{CO}_{2}$ by the water-gas shift reaction. This set of processes is quite mature but is being improved by competing catalyst manufacturers and developers of hydrogen production technology, with ammonia manufacture a main outlet. Apart from advanced research on separation processes, there appears to be minimal need for DOE participation developing processes for manufacture of merchant hydrogen.

Production of pure hydrogen is expensive and a major consumer of energy. Clean fuels production processes that conserve hydrogen and involve in situ conversion of $\mathrm{CO}$ and water to $\mathrm{H}_{2}$ provide important gains in efficiency and cost reduction through heat integration and provide a preferred option for synthetic fuels manufacture.

\section{Synthetic Natural Gas Production}

While the current low cost of natural gas makes synthetic natural gas (SNG) uneconomical, there have been important advances in synthesis processes from industrial and government-funded $\mathrm{R} \& D$ that allow use of the low $\mathrm{H}_{2} / \mathrm{CO}$ ratios from advanced gasifiers, increased tolerance for sulfur, and improved design of reactors for the highly exothermic methanation 'reaction. Processes for direct production of methane by coal pyrolysis and lowtemperature catalytic gasification followed by cryogenic separation offer additional pathways.

It has been estimated (COGARN, 1987) that these newer technologies can reduce the cost of stand-alone SNG production by approximately 25 percent. However, the resulting cost will still be higher than projections by the EIA (Energy Information Administration) for natural gas wellhead prices of about $\$ 3.50 /$ thousand cubic feet or less in 2010. Thus, development of an economic incentive for large single-product plants is not expected before the late mid- or longterm periods (2020-2040). The DOE coal program does not include major programs devoted to catalytic SNG synthesis. This seems appropriate in view of the long time horizon and the excellent capabilities outside DOE. Advanced low-temperature gasification processes, however, 
ultimately have the potential to increase efficiency and reduce the cost of manufacturing SNG, liquid fuels, and chemicals.

Separating the methane formed directly in gasification processes by pyrolysis and by reactions in low-temperature gasification can be achieved cryogenically or by diffusion. The latter requires advances in high-temperature selective diffusion membranes.

\section{Methanol from Syngas}

Methanol has been an important commodity for many years, with uses in the chemical industry and as a solvent. It can be used neat as a motor fuel and, with the requirement for inclusion of oxygenates in gasoline, its use in preparing oxygenated components by reaction with olefins has grown rapidly. Manufacture of methanol from coal is currently more expensive than manufacture from natural gas.

Methanol is made by the catalytic conversion of syngas at about $250^{\circ} \mathrm{C}\left(480^{\circ} \mathrm{F}\right)$ at 60 to 100 atmospheres pressure. Both coal and natural gas can be used as syngas sources. The current commercial processes use a fixed-bed catalytic reactor in a gas recycle loop. A wide range of mechanical designs are used to control the heat released from the reaction. New developments in methanol technology include fluidized-bed methanol synthesis and use of a liquid-phase slurry reactor for methanol synthesis. The slurry technology offers improved control of temperatures; it was developed in LaPorte, Texas, in a joint DOE/industry program.

There is relatively little industrial R\&D activity on processes using syngas with low $\mathrm{H}_{2} / \mathrm{CO}$ ratios and the sulfur concentrations achievable with hot gas desulfurization. For use of coal, such a process could be less costly and more efficient than current technology and could be integrated advantageously with electricity generation in a coproduct system.

\section{Liquid Hydrocarbons from Syngas (Fischer-Tropsch Synthesis)}

While gasoline hydrocarbons can be manufactured from methanol by the Mobil methanolto-gasoline process, production by F-T (Fischer-Tropsch) synthesis is currently favored for new overseas facilities when low-cost gas is available. F-T synthesis can produce premium-quality diesel and jet fuel with minimum processing. Gasoline is also produced but requires more extensive upgrading to meet octane number specification. DOE has been active in applying the slurry reactor technique to this process. The ability of this process to handle high-molecularweight wax and to use the low $\mathrm{H}_{2} / \mathrm{CO}$ ratio gas from coal without the need for shifting to a higher ratio is important. Limited DOE development work is being conducted in LaPorte, Texas, in cooperation with industry groups.

Recent DOE-sponsored systems and cost studies (Gray, 1994; Tam et al., 1993) using the DOE financing basis (see Chapter 2 and Glossary) have projected equivalent crude prices of $\$ 30$ to $\$ 35 / \mathrm{bbl}$ for stand-alone production of high-quality gasoline and distillate fuels (diesel, aviation). When production of F-T liquids was combined with gasification-based power generation, the equivalent crude cost was reduced by $\$ 5$ to $\$ 7 / \mathrm{bbl}$, bringing it closer to the EIA reference case projected price for crude oil of $\$ 28 / \mathrm{bbl}$ in 2010 (EIA, 1994). Thus, the studies 
indicate the possibility of coal-based fuels production in the mid-term period (2006-2020), which is about the same period as major construction of gasification-based power generation facilities.

Further cost reductions can be anticipated by continued systems studies; however, critical examination of the premium fuel credit should be included. Opportunities for cost reductions by research include optimization of once-through processes and development of catalyst systems compatible with sulfur levels attainable using hot gas cleanup.

\section{Products from Direct Liquefaction and Pyrolysis of Coal}

\section{Direct Coal Liquefaction by Hydrogenation}

Following the oil embargo of 1973 , direct liquefaction was the subject of intensive $R \& D$, both industry and DOE funded. Since then, the drop in oil prices has led to abandonment of all large-scale development and drastic reductions in both industrial and DOE research activities. The products of direct liquefaction can be refined to produce highly aromatic high-octane gasoline and high-quality diesel fuel. Jet fuels and heating oil can also be produced. A design, systems, and cost analysis based on results from DOE's advanced liquefaction R\&D facility in Wilsonville, Alabama, projected an equivalent crude price based on utility financing of approximately $\$ 33 / \mathrm{bbl}$ using Illinois No. 6 coal (DOE, 1993b). Use of lower-cost western coal might reduce the cost to approximately $\$ 30 / \mathrm{bbl}$. There is optimism at DOE and among some industry groups that with continued $R \& D$ and systems analyses the DOE goal of $\$ 25 / \mathrm{bbl}(1991$ dollars) for liquids from coal can be reached.

The aforementioned estimate based on Wilsonville data concerned dedicated coal liquefaction plants. Coproduction of liquids and electricity with advanced gasification systems can be expected to reduce costs. The reduction would likely be significant but probably less than the $\$ 5$ to $\$ 7 / \mathrm{bbl}$ estimated for F-T liquefaction. Coprocessing of coal with residual fuel or tar in oil refineries has been studied by both industry and DOE.

While use of coal introduces both coal and ash handling requirements, improved process performance and continued low cost of coal are expected to revive commercial interest in the mid-term period (2006-2020) if oil prices follow EIA projections (EIA, 1994). Several research areas offer promise for reducing the cost and improving the efficiency of direct liquefaction by hydrogenation: use of raw coal gasifier product with a catalyst capable of in situ shifting of $\mathrm{CO}$ to $\mathrm{H}_{2}$, removal of the oxygen in coal as $\mathrm{CO}_{2}$ rather than water, use of a low-pressure reactor, and minimized production of light hydrocarbons.

\section{Direct Coal Liquefaction by Pyrolysis}

Controlled heating of coal in pyrolysis can produce modest yields of liquids. The heat of pyrolysis is small, and, if the char product can be used without cooling, high thermal efficiencies can be achieved. The pyrolysis liquids are low in hydrogen and high in oxygen compared to petroleum residuum or bitumen but could be coprocessed with bitumen or fed to a direct coal liquefaction unit. Their tendency to polymerize on storage limits their use as a supplementary fuel for power generation without further processing. 
While probably of lower value to a refinery than bitumen, it seems possible that coproduction with gasification could make pyrolysis liquids competitive with tar in the same period as deployment of advanced power generation systems. DOE studied coproduction of pyrolysis char and coke (mild gasification) and began construction of demonstration facilities, but no further funding has been requested in the FY 1995 budget. A CCT demonstration of this technology using low-sulfur western coal is under way; the plan is to market pyrolysis liquids as power plant fuel oil and to burn the coke.

\section{Coal Refineries and Coproduct Systems}

The energy industries are mostly specialized, oriented to a narrow range of products and markets. Electric utilities supply electricity along with some steam to local users; oil refineries supply liquid fuels along with some petrochemical feedstocks; and gas suppliers collect, purify, and transmit natural gas to end users. Government regulations differ for these areas, and separate specialty business units have been established to deal with these separate regulatory systems. As discussed in Chapter 2, this regulatory environment has been changing to make it more attractive for groups outside the traditional utilities to generate and sell electric power.

The concept of a coal refinery, analogous to an oil refinery, has been discussed for many years, but the availability of low-cost petroleum has provided a disincentive to implement the coal refinery concept. More recently, EPACT directed DOE to examine the potential of coal refineries, and a report has been published (DOE, 1991). Screening studies by the Mitre Corporation (Gray, 1994) identified major synergies between advanced power generation based on gasification and production of clean fuels and chemicals. The preceding discussion identified several examples of cost and energy savings from the manufacture of a variety of products from coal gasification. The available data (Gray, 1994; Tam et al., 1993) indicate an equivalent crude cost of $\$ 5$ to $\$ 7 / \mathrm{bbl}$ less for a combination of F-T synthesis and electric power generation than for stand-alone plants for liquids production. In these estimates the economic return on electric power production was held constant and the savings were applied to the liquid coproducts.

There are many other product combinations besides coal liquids and electric power, and quantitative studies can provide essential strategic guidance for both $R \& D$ and identification of optimized combinations of electric power, fuels, and chemical products. The incentives for coproduction by refineries, chemical plants, or independent producers of clean gas and other products will vary widely with location and the organizations involved. Cooperation with potential users is important to the success of such strategic planning studies.

The funding for DOE programs to produce clean liquid fuels from coal has declined significantly in recent years (see Chapter 6). The discussion above has indicated the possibility of introducing liquid fuels from coal at about the same time as new IGCC-based electric power generation facilities might be constructed. The timely availability of appropriate demonstrated technology will depend on initiating programs to investigate opportunities and develop coproduct systems as soon as possible. 


\section{Conclusions}

1. Gasification plays a critical role as the first and most costly step in the production of electric power by combined-cycle systems and in the production of clean gaseous and liquid fuels and chemical products.

2. Gasification options exist that offer potentially greater efficiencies than currently available commercial systems. Among the relatively unexploited options, low-temperature fluidized-bed gasification systems, with the possible use of catalysts, appear to be the most versatile for providing the entire array of future products from coal. A few examples of such systems are in development, but the committee believes there are additional opportunities for further development.

3. The current DOE gasification program is devoted almost entirely to gasifier technology for power generation. However, gasification efficiency improvements are also needed to produce clean gaseous and liquid fuels. The proposed FY 1995 budget reductions are not consistent with this need.

4. Materials research leading to membrane cliffusion techniques for recovering a byproduct hydrogen stream is a major opportunity for DOE coal research relating to the production of pure hydrogen from coal-derived gas.

5. Production of SNG from coal is not expected to be of importance until late in the long term.

6. The major opportunity to improve thermal efficiency and cost in SNG production is in the gasification step.

7. High-efficiency oxygen-blown gasifiers developed for combined-cycle power generation would also be applicable to use in SNG manufacture.

8. For large single-product plants, direct coal liquefaction offers a 5 to 10 percent higher efficiency with correspondingly less $\mathrm{CO}_{2}$ production than coal-based F-T syntheses, with production of methanol falling between these two limits. Similarly, the cost of producing a slate of refined transportation fuels by direct liquefaction is potentially lower than for the coal-based F-T synthesis gas-based fuels.

9. An estimate of the petroleum crude oil prices at which the products from a large direct liquefaction plant meeting current refined fuel specifications could compete is around $\$ 30 / \mathrm{bbl}$ using western coal and utility financing. For F-T liquids the equivalent crude oil price would be approximately $\$ 5 / \mathrm{bbl}$ higher (i.e., $\$ 35 / \mathrm{bbl}$ ), with methanol production about the same as direct liquefaction. With typical oil industry financing, the equivalent crude prices would be on the order of $\$ 5$ to $\$ 10 / \mathrm{bbl}$ higher.

10. Recent cost estimates for coproduction of coal liquids and electric power indicate that coal liquids might compete with petroleum at $\$ 25 / \mathrm{bbl}$ or less, with the possibility of coal-derived liquid fuel production at about the same time as installation of advanced IGCC power generation facilities.

11. Continued research in conversion chemistry and process optimization have the potential to reduce the cost of coal liquids from large liquefaction plants to the DOE goal of $\$ 25 /$ bbl (1991 dollars). 
12. There is little need, at this time, for large pilot plant or demonstration programs, but a bench-scale and small pilot plant program is needed to evaluate promising leads and provide focus for laboratory-scale research in direct liquefaction.

13. Advances and maintenance of core competencies in direct coal liquefaction technology in the United States depend increasingly on DOE activities, since R\&D on direct coal liquefaction has dwindled to a very low level in industry.

14. Continued reductions in funding will cause a major degradation in the effectiveness of the DOE coal liquefaction program. This trend places the nation's long-term coal liquefaction option at risk because government support has become critical in sustaining U.S. competency in this area.

\section{Recommendations ${ }^{9}$}

1. *An expanded DOE role should be established to ensure the timely availability of the most efficient and economic gasification systems for future uses of coal in power generation and in the production of clean gases and liquids.

2. A research program should be established to improve the efficiency of gasification systems suitable for clean fuels production. The DOE program for improvement of gasifier efficiency also should include systems that produce methane directly and are applicable to both SNG and power generation.

3. No direct program on SNG manufacture is recommended.

4. *DOE's R\&D program for coal liquefaction technologies should be continued at least at the FY 1994 level, with the goals of decreasing the cost of coal liquids and increasing overall efficiency.

5. Within DOE's coal liquefaction program, the effects of efficiency and other improvements on reducing $\mathrm{CO}_{2}$ production should be considered.

6. Within the DOE program on coal liquefaction, highest priority should be given to direct coal liquefaction research, concentrating on fundamental coal chemistry and innovative process development.

7. DOE sponsorship of small pilot plant facilities should be continued to test and improve liquefaction technologies, but larger pilot plants should not be built in the near term without significant private sector participation.

8. *An assessment of strategies and opportunities for coproduction of premium liquid fuels and gasification-based power should be an important component in planning a program for the introduction of liquid fuels from coal.

\footnotetext{
${ }^{9}$ Asterisks $\left(^{*}\right)$ identify the most important recommendations.
} 


\section{SYSTEMS ANALYSIS AND STRATEGY STUDIES}

One critical activity identified by the committee that is not highlighted in DOE's current planning documents is systems analysis. This activity is essential to assessing coal R\&D needs and priorities and to strategic planning. Given the expanding number of process options for advanced power generation, fuels production, and environmental controls, which designs are the most promising to pursue? How should complex processes be configured to achieve optimal results? How should individual components be designed to maximize performance and minimize cost? How do advanced process concepts compare to currently commercial technology and to each other? What are the most promising markets for advanced technologies, and what are the greatest technical risks? How do the various technical and economic uncertainties for new process designs affect projections of performance and cost, and how can targeted R\&D best reduce critical uncertainties? A well-designed systems analysis program should be able to address such questions.

The DOE Fossil Energy program already has in place a significant systems and engineering analysis activity at both its Morgantown Energy Technology Center (METC) and its Pittsburgh Energy Technology Center (PETC) and additional capabilities at DOE headquarters in Washington. Each of these offices is involved in analysis and evaluation of processes and programs within selected areas of DOE activity. Analytical approaches of varying sophistication are employed for process analysis and evaluation, often with reliance on outside contractors in addition to in-house staff.

A preliminary look at DOE's ongoing activity in systems analysis indicates a significant amount of activity spread among METC, PETC, and headquarters. A major shortcoming, however, appears to be a lack of systematic assumptions and design premises within and across the full suite of DOE's advanced energy conversion and environmental control research programs. Rather, it appears that different parts of the DOE organization, working with a variety of different contractors, employ different assumptions and approaches-circumstances that preclude rigorous comparisons or evaluations of technologies in a given category (e.g., advanced power systems or advanced fuel systems).

Communicating the results of analyses to interest groups within and outside DOE is another important contribution of systems studies (see, for example, NRC, 1992), a contribution that could be greatly improved by consistency and clarity in the assumptions and methods used for analysis. Similarly, greater efforts to incorporate feedback from industrial and other stakeholders, coupled with timely and systematic publication of results, are also needed. A more coherent approach to systems analysis could be of real value for strategic R\&D planning.

Of substantial value are the advanced analytical and computer-based methods for analysis, synthesis, and design of complex processes that DOE has begun to develop in recent years. For example, new methods to address technical and economic uncertainties are especially critical to characterize advanced processes and designs properly at the early stages of development. Characterization and analysis of uncertainties are also critical to identifying robust system designs, risks, potential markets, and key problem areas that should be targeted for research to reduce technological risks. While DOE has supported the development of advanced modeling approaches for systems analysis and design and is beginning to adopt some of these methods for 
R\&D management, more rapid implementation of a rigorous systems analysis methodology could be of significant value for long-term strategic planning.

\section{Conclusions}

1. The growth in opportunities to use coal to produce electricity, fuels, chemicals, and coproducts calls for expanding and strengthening DOE's Office of FE systems analysis activity, which plays a critical role in coal-related $R D D \& C$ and strategic planning.

\section{Recommendations $^{10}$}

1. *An expanded and more prominent role for systems analysis is recommended in developing RDD\&C strategies for the DOE coal program. This activity should establish a clearly stated and consistent set of criteria, assumptions, and design premises that can be applied to all technologies in a given category, to facilitate rigorous comparisons. Advanced methods of analysis, design, and risk evaluation should be adopted, and extensive interaction with the user community-notably U.S. industry - and active dissemination of major study results and methods should be pursued.

\section{TECHNOLOGY DEMONSTRATION AND COMMERCIALIZATION}

An important goal for the DOE coal program, as specified by EPACT, is to accelerate the development and commercial introduction of new technologies related to coal use. A major additional objective is to increase the competitiveness of U.S. firms engaged in supplying equipment and advanced technology to the power-generating industry at home and abroad. Before commercialization, large-scale demonstration is generally necessary to provide credible evidence of improved performance and practicability. These demonstrations are expensive and are generally cost shared by DOE and industry. The DOE role can vary from operating and managing a cost-shared facility to cofunding a program located at an industrial site and managed by the industrial partner.

The demonstration programs under DOE's FE R\&D budget are generally of the first type, while the CCT demonstration projects are generally of the second type, with DOE operating only as a cofunding agency. The annual budget for FE coal R\&D demonstration programs is approximately $\$ 150$ million/year; additional funding for demonstrations of fuel cells and advanced turbines is included in the Office of FE's natural gas budget. ${ }^{11}$ The CCT program will expend about $\$ 6.9$ billion over 14 years on 45 programs; with industry contributing more than two-thirds of the total funding. The major CCT effort is expected to result in commercial

\footnotetext{
${ }^{10}$ Asterisks $(*)$ identify the most important recommendations.

"For FY 1994, \$74 million; for FY 1995 (request), \$113 million.
} 
applications, and, while most of the activities are not yet completed, most of the programs seem to be well chosen, based on the level of private support. Significant future use of these technologies will depend on a follow-up commercialization program that alleviates concerns about costs and reliability of advanced technologies (see Chapter 8). The extent of DOE involvement necessary to stimulate private sector investment in such a program requires further assessment, taking into account any social costs resulting from delay in the implementation of advanced coal-based systems.

At the request of the Secretary of Energy, the National Coal Council recently completed a study of commercialization opportunities and recommended a strategy for overcoming the barrier of the high costs and risks involved in using "pioneer technologies." It was recommended that approximately $\$ 1.4$ billion be provided over 15 years (1995-2010) to provide about 10 to 15 percent of total capital and to help offset operating risks for the first plant after the demonstration plant, with a decreasing amount for the next three to five installations. Cost sharing would be for a percentage of that part of the commercial application that represents technical and economic risks not present in commercially available technology. This initiative would be in addition to the DOE FE R\&D and CCT programs for technology demonstration.

\section{Conclusions}

1. Adequate technology demonstration and commercialization programs are essential for timely commercial application of new coal use technologies.

2. The timely introduction of clean coal technologies will depend on further demonstrations of a few pioneer installations beyond the CCT program to allay concerns about costs and reliability; some federal participation will be necessary to stimulate private sector investment.

3. Cost sharing of the risk differential between pioneer plants and commercially available technologies will accelerate the commercial acceptance of many of the new coal-based technologies.

\section{Recommendations $^{12}$}

1. *Support of the current CCT program should be continued and the ongoing program completed. While no further solicitations are planned under the existing CCT program, the FE coal R\&D program should continue to cofund demonstrations of selected Group 2 and Group 3 advanced clean coal technologies beyond those currently being demonstrated by the CCT program.

2. Any uncommitted funds from the CCT program should continue to be spent on activities related to the domestic use of clean coal technologies.

\footnotetext{
${ }^{12}$ Asterisks $\left(^{*}\right)$ identify the most important recommendations.
} 
3. *An incentive program should be developed and implemented that would offset the capital and operating cost risks associated with early commercial applications of technologies previously demonstrated at a commercial scale.

4. Management of an incentive program by DOE should be the same as that of the current CCT program. The elements should be the same, except that cost sharing applies only to the risk components and not the total project costs. Because the solicitation, negotiation, design, construction, and demonstration phases can take five to seven years, multiple solicitations in several fiscal years should be conducted near the end of the demonstrations of the current 45 projects.

\section{ADVANCED RESEARCH PROGRAMS}

The principal aims of the DOE coal advanced research program are to pursue technology goals and exploratory research opportunities while maintaining a balance between revolutionary research and evolutionary engineering development programs. In conducting a strategic assessment of the DOE coal advanced research activities, the committee did not aim to provide a comprehensive list of research opportunities. However, some critical areas for coal-related research were identified during the committee's review of current programs. These include research on combustion and gasification, materials, and coal conversion and catalysis, as discussed in Chapter 9. In identifying these areas the committee accorded special importance to research areas unlikely to be addressed outside the FE coal R\&D program. For example, the study of coal chemistry and catalytic reactions is not supported to a significant extent outside DOE's FE coal R\&D program. The committee supports the DOE view, outlined in the recent FE advanced research strategic plan (DOE, 1994b), that advanced research activities within the coal program should be directed toward meeting the strategic objectives defined for advanced clean/efficient power systems and clean fuel systems. In line with the committee's earlier recommendation to modify coal RDD\&C strategic planning horizons, the committee believes that the advanced research program should devote more effort to mid- and long-term requirements than is now the case.

The advanced research budget declined by about 30 percent in real terms between FY 1988 and FY 1994, with an additional decrease of approximately 25 percent proposed for FY 1995. Comparing the FY 1994 enacted appropriation and the FY 1995 budget request indicates that major reductions are proposed in coal liquefaction ( 84 percent), components (50 percent), and materials ( 25 percent). The reductions in funding for coal liquefaction, when combined with a proposed 36 percent reduction in funding for liquefaction programs outside the advanced research program, are of special concern, given the prospects for producing coal liquids in the mid to long term. . $^{13}$

In Chapters 6 and 7 the committee identified ample opportunities for major contributions to fuels and power generation programs from advanced research. However, DOE's budget reductions for advanced research are not commensurate with the requirements for advancement

\footnotetext{
${ }^{13}$ For a more detailed discussion of advanced research budgets, see Chapter 9 .
} 
of coal technology, notably the increasing needs for lower-cost, more efficient, and more environmentally acceptable use of coal.

\section{Conclusions}

1. There are increased needs and opportunities for advanced research directly related to achieving cost reduction and improved performance goals for advanced power systems and fuels production.

2. The recent trend in decreasing support for coal-related advanced research activities is not commensurate with the expanding needs to support DOE's mission.

\section{Recommendations $^{14}$}

1. *Increased resources should be devoted to advanced research activities to support DOE's strategic objectives for coal, with emphasis on needs identified for mid- and long-term improvements in efficiency, emissions reduction, and cost for both power generation and fuels production.

\section{THE ENERGY POLICY ACT OF 1992 (EPACT)}

In this section the committee's conclusions and recommendations are interpreted in the context of the individual sections of EPACT that relate to coal (see Chapter 1 and Appendix B).

There is considerable overlap between the different coal-related sections of EPACT. For example, Section 1301 requires DOE to establish RDD\&C programs on coal-based power generation technologies. One of the technologies addressed by DOE in this context is MHD, which is also addressed specifically in Section 1311. Similarly, issues relating to the costcompetitive conversion of coal to fuels are addressed in Sections 1301, 1305, 1309, and 1312.

In addition, there is very wide variation in the scope of different EPACT provisions. Section 1301 addresses the whole range of coal-based technologies, whereas other sections focus on very specific aspects of coal utilization, such as coal-fired diesel engines or low-rank coal R\&D.

For these reasons of overlap and disparity of scope, the committee chose to develop and organize its conclusions and recommendations on the basis of strategic planning scenarios (Chapter 4) rather than by the individual sections of EPACT. The committee's approach has the advantage of providing a robust framework that can readily be adapted to respond to changes in the scenarios.

Table 10-4 summarizes the major EPACT provisions relating to coal, key features of relevant DOE programs, and the committee's comments and ratings in terms of priority for DOE. In assessing priorities for DOE activities, the committee used the criteria developed in Chapter 4. Prime considerations were the timing and goals of the program in light of the

\footnotetext{
${ }^{14}$ Asterisks $(*)$ identify the most important recommendations.
} 
scenarios developed by the committee; the potential for technological success; likely markets; the potential for controlling, reducing, or eliminating environmentally important wastes; and the need for DOE participation, given the current development status of the technology, and other industrial and federal programs. For example, if technologies are already available commercially, the committee generally recommended a low priority in this area for DOE activities. Similarly, if there is currently extensive R\&D activity in the private sector, the committee recommended that DOE leverage this effort.

The committee concluded that DOE has responded to some degree to all the sections of EPACT addressed in the study. However, the extent of the response varies widely. In the case of power generation systems, addressed primarily in EPACT Section 1301, the DOE Advanced Clean/Efficient Power Sýstems program is very responsive to the EPACT requirements to "ensure a reliable electricity supply" while complying with environmental regulations and controlling emissions (see Chapter 7). The committee endorses DOE's approach to the development of advanced coal-based power generation technologies, given the likely need for new, clean, efficient coal-based power generation capacity in the mid to long term (2006 through 2040). The committee's recommendations for priorities in developing the possible technology options are presented earlier in this chapter (under "Power Generation Systems").

The need to commercialize coal-based technologies, preferably by 2010 , is addressed in EPACT sections 1301 and 1321. The committee concluded that DOE's CCT program represents an excellent start in the area of commercializing advanced power generation technologies, but, as noted above, plans need to be developed by DOE for activities beyond the conclusion of current CCT activities.

In contrast to DOE's generally adequate response to the sections of EPACT addressing power generation, its activities in coal liquefaction fall short of EPACT requirements, the committee concluded. As noted in Chapters 6 and 9, there was a significant reduction in funding of coal liquefaction activities between FY 1993 and FY 1994, and a significant further reduction is proposed for FY 1995. Given the likely growth in demand for coal liquids over the mid- to long-term periods (see Chapter 4) and the decline in industry-supported liquefaction research, the priority that EPACT gives to DOE liquefaction activities appears to be well founded.

Coproduction of electricity and other products, such as coal liquids, also is accorded relatively high importance by EPACT (sections 1304, 1305, and 1312), but it does not represent a major element of DOE's current program. Given the likely future growth in the use of coal for clean fuels and specialty products and the potential for economically attractive manufacture based on coproduction (see Chapter 6), the committee considers increased DOE effort in assessing coproduct systems or "coal refineries, " in keeping with EPACT requirements, to be appropriate.

EPACT Section 1307 requires DOE to assess the feasibility of establishing a national clearinghouse for the exchange and dissemination of information on coal-related technology. The committee noted that means already exist to disseminate DOE reports on coal technologies to interested parties. Thus, any clearinghouse activity should be broader in scope and should involve participants from inside and outside DOE. However, the committee considered that the need for such an activity should be established by a market survey of potential users prior to significant investment of resources. 
In comparing all the activities within DOE's current coal program and those mandated by EPACT, the committee noted a significant discrepancy in priorities. The current DOE program focuses on relatively near term activities, notably the development, demonstration, and commercialization of coal-based power generation systems by 2010, at the expense of longerterm research programs. Such longer-term programs would position the United States to respond to future energy scenarios in which coal assumes increasing importance for uses other than power generation. In contrast to the DOE approach, the coal-related provisions of EPACT endorse the development of a longer-term, more balanced spectrum of coal-based technologies. The committee's recommendation that strategic planning for coal should address requirements for periods to the middle of the next century is more consistent with the EPACT approach than with DOE's current priorities.

\section{Conclusions}

1. The current DOE program is appropriate and responsive to EPACT sections related to coal-based electric power generation.

2. EPACT places significant emphasis on programs related to the expansion of coal use for manufacture of.liquid and gaseous fuels and specialty products.

3. The DOE program covering uses of coal beyond power generation has decreased in recent years.

4. The need for a national clearinghouse to exchange and disseminate data on coal technologies has not yet been established.

\section{Recommendations $\mathbf{s}^{15}$}

1. There should be increased DOE support of fundamental and applied research aimed at longer-term uses of coal (2006-2040) to balance decreased industry research, guarantee the maintenance of U.S. technological expertise in this area, and position the United States to respond to future energy needs.

2. *Within the DOE coal program there should be an increasing emphasis on the production of clean fuels and other carbon-based products over time.

3. No further action should be taken to establish a national clearinghouse until a need has been established based on a market survey of potential users.

\section{REFERENCES}

Clinton, W.J., and A. Gore, Jr. 1993. The Climate Change Action Plan. Washington, D.C.: The White House.

\footnotetext{
${ }^{15}$ Asterisks $(*)$ identify the most important recommendations.
} 
COGARN. 1987. Coal Gasification: Direct Applications and Synthesis of Chemicals and Fuels. U.S. Department of Energy Coal Gasification Research Needs Working Group, DOE/ER-0326. Washington, D.C.: DOE.

DOE. 1991. Report to Congress: Coal Refineries: A Definition and Example Concepts. U.S. Department of Energy, DOE/FE-0240P. Washington, D.C.: National Academy Press.

DOE. 1993a. Clean Coal Technologies: Research, Development, and Demonstration Program Plan. U.S. Department of Energy, DOE/FE-0284. Washington, D.C.: DOE.

DOE. 1993b. Direct Coal Liquefaction Baseline Design and System Analysis: Final Report on Baseline and Improved Baseline, Executive Summary. Prepared for U.S. Department of Energy, Pittsburgh Energy Technology Center, under contract no. DEAC22 90PC89857. Pittsburgh, Pennsylvania: DOE.

DOE. 1994a. Strategic Plan: Fueling a Competitive Economy. U.S. Department of Energy, DOE/S-0108. Washington, D.C.: DOE.

DOE. 1994b. Fossil Energy Advanced Research: Strategic Plan. Review draft, July 15. Washington, D.C.: DOE.

DOE. 1994c. Comprehensive Report to Congress: Clean Coal Technology Program, Completing the Mission. Washington, D.C.: U.S. Department of Energy.

EIA. 1994. Annual Energy Outlook 1994. Energy Information Administration, U.S. Department of Energy, DOE/EIA-0383(94). Washington, D.C.: DOE.

EPRI. 1993. TAG ${ }^{\mathrm{TM}}$ Technical Assessment Guide. EPRI TR-102275-V1R7. Vol. 1, Rev. 7. Palo Alto, California: EPRI.

Frey, H.C., E.S. Rubin, and U.M. Diwekar. 1994. Modeling uncertainties in advanced technologies: Application to a coal gasification system with hot gas cleanup. Energy 19(4): 449-463.

Gray, D. 1994. Coal Refineries: An Update. Prepared for Sandia National Laboratories by the Mitre Corporation under contract no. AF-7166. McLean, Virginia: The Mitre Corporation.

Maude, C. 1993. Advanced power generation-A Comparative Study of Design Options for Coal. London: International Energy Agency Coal Research. 
Merrow, E., K.E. Phillips, and C.W. Myers. 1981. Understanding Cost Growth and Performance Shortfalls in Pioneer Process Plants. Prepared for the U.S. Department of Energy by the Rand Corporation, R-2569-DOE. Santa Monica, California: Rand Corporation.

NCC. 1994. Clean Coal Technology for Sustainable Development. Washington, D.C.: National Coal Council.

NRC. 1992. The National Energy Modeling System. Energy Engineering Board, National Research Council. Washington, D.C.: National Academy Press.

Tam, S.S., D.C. Pollock, and J.M. Fox. 1993. The combination of once-through FischerTropsch with baseload IGCC technology. P. 306 in Alternate Energy '93 held April 28-30, 1993 in Colorado Springs, Colorado. Arlington, Virginia: Council on Alternate Fuels. 
Table 10-1 Advanced Coal-Based Power Systems Supported by DOE

\begin{tabular}{|c|c|c|c|c|c|c|}
\hline $\begin{array}{l}\text { Technology } \\
\text { (target year for } \\
\text { commercial design) }\end{array}$ & $\begin{array}{l}\text { Design } \\
\text { Efficiency } \\
\text { (percent) }\end{array}$ & $\begin{array}{l}\text { Coal Conversion } \\
\text { Components }\end{array}$ & $\begin{array}{l}\text { Power Generation } \\
\text { Components }\end{array}$ & $\begin{array}{c}\text { Particulate Control } \\
\text { System }\end{array}$ & $\begin{array}{l}\mathrm{SO}_{2} \text { Control } \\
\text { System }\end{array}$ & $\begin{array}{l}\mathrm{NO}_{\mathrm{x}} \text { Control } \\
\text { System }\end{array}$ \\
\hline $\begin{array}{l}\text { New pulverized coal } \\
\text { (commercial } \\
\text { baseline) }\end{array}$ & $38-42$ & Supercritical boiler & $\begin{array}{l}3,500 \text { to } 4,500 \text { psi } \\
\text { steam turbine }\end{array}$ & $\begin{array}{c}\text { ESP or } \\
\text { fabric filter }\end{array}$ & $\begin{array}{l}\text { Wet lime or } \\
\text { limestone FGD }\end{array}$ & $\begin{array}{c}\text { Low } \mathrm{NO}_{x} \text { burners } \\
+ \text { SCR }\end{array}$ \\
\hline \multicolumn{7}{|l|}{ GROUP 1} \\
\hline \multicolumn{7}{|l|}{ SYSTEMS } \\
\hline LEBS (2000) & 42 & Supercritical boiler & $\begin{array}{c}4,500 \text { psi steam } \\
\text { turbine }\end{array}$ & \multicolumn{3}{|c|}{ Advanced flue gas cleanup + combustion controls ${ }^{2}$} \\
\hline PFBC-1 (2003) & $\sim 40$ & $\begin{array}{c}\text { Bubbling and } \\
\text { circulating bed PFBC } \\
\text { units }\end{array}$ & $\begin{array}{l}1,800 \text { psi steam } \\
\text { turbine } \\
+ \text { gas turbine }\end{array}$ & $\begin{array}{l}\text { Cyclones }+ \\
\text { fabric filter }\end{array}$ & $\begin{array}{l}\text { In-bed limestone } \\
\text { or dolomite }\end{array}$ & $\begin{array}{l}\text { Combustion } \\
\text { controls }\end{array}$ \\
\hline IGCC-1 (1997) & -40 & $\begin{array}{l}\mathrm{O}_{2} \text {-blown entrained- } \\
\text { bed gasifiers }\end{array}$ & $\begin{array}{l}2350^{\circ} \mathrm{F} \text { gas turbine } \\
\text { +HRSG/turbine }\end{array}$ & $\begin{array}{l}\text { Cold gas } \\
\text { quenching }\end{array}$ & $\begin{array}{l}\text { Cold gas } \mathrm{H}_{2} \mathrm{~S} \\
\text { absorption }\end{array}$ & $\begin{array}{l}\text { Cold gas cleanup } \\
+ \text { steam injection }\end{array}$ \\
\hline \multicolumn{7}{|l|}{$\frac{\text { GROUP } 2}{\text { SYSTEMS }}$} \\
\hline EFCC (1997) & 45 & $\begin{array}{c}\text { Slagging combustor } \\
+2300^{\circ} \mathrm{F} \text { heat } \\
\text { exchanger }\end{array}$ & $\begin{array}{c}2350^{\circ} \mathrm{F} \text { gas turbine } \\
+ \text { HRSG/turbine }\end{array}$ & Fabric filter & $\begin{array}{l}\text { Wet } \\
\text { FGD }\end{array}$ & $\begin{array}{c}\text { Combustion } \\
\text { controls ( }+ \text { SCR if } \\
\text { needed) }\end{array}$ \\
\hline PFBC-2 (2005) & 45 & $\begin{array}{l}\text { Circulating PFBC } \\
+ \text { coal pyrolyzer }\end{array}$ & $\begin{array}{c}2350^{\circ} \mathrm{F} \text { gas turbine } \\
+2,400 \text { psi steam } \\
\text { turbine }\end{array}$ & Hot gas filtration & $\begin{array}{l}\text { In-bed } \\
\text { limestone or } \\
\text { dolomite }\end{array}$ & $\begin{array}{c}\text { Combustion } \\
\text { controls } \\
(+ \text { SCR if needed })\end{array}$ \\
\hline IGCC-2 (2002) & 45 & $\begin{array}{c}\text { Oxygen- or air-blown } \\
\text { fluidized-- } \\
\text { bed gasifier }\end{array}$ & $\begin{array}{c}2350^{\circ} \mathrm{F} \text { or } 2500+{ }^{\circ} \mathrm{F} \\
\text { gas turbine } \\
+ \text { HRSG/turbine }\end{array}$ & Hot gas filtration & $\begin{array}{c}\text { Hot gas } \\
\text { desulfurization }+ \\
\text { in-bed limestone } \\
\text { (optional) }\end{array}$ & $\begin{array}{c}\text { Combustion } \\
\text { controls } \\
(+ \text { SCR if needed })\end{array}$ \\
\hline
\end{tabular}




\begin{tabular}{|c|c|c|c|c|c|c|}
\hline $\begin{array}{l}\text { Technology } \\
\text { (target year for } \\
\text { commercial design) }\end{array}$ & $\begin{array}{l}\text { Design } \\
\text { Efficiency } \\
\text { (percent) }\end{array}$ & $\begin{array}{l}\text { Coal Conversion } \\
\text { Components }\end{array}$ & $\begin{array}{l}\text { Power Generation } \\
\text { Components }\end{array}$ & $\begin{array}{c}\text { Particulate Control } \\
\text { System }\end{array}$ & $\begin{array}{l}\mathrm{SO}_{2} \text { Control } \\
\text { System }\end{array}$ & $\begin{array}{l}\mathrm{NO}_{\mathrm{x}} \text { Control } \\
\text { System }\end{array}$ \\
\hline \multicolumn{7}{|l|}{$\frac{\text { GROUP } 3}{\text { SYSTEMS }}$} \\
\hline HIPPS (2003) & 50 & $\begin{array}{l}\text { High-temperature } \\
\text { advanced furnace }\end{array}$ & $\begin{array}{c}2500^{\circ} \mathrm{F} \text { gas turbine } \\
+\mathrm{HRSG} / \text { turbine } \\
(+ \text { auxiliary fuel if } \\
\text { needed })\end{array}$ & \multicolumn{3}{|c|}{ Advanced flue gas cleanup system + in-furnace controls ${ }^{n}$} \\
\hline $\begin{array}{l}\text { Improved PFBC-2 } \\
(2010)\end{array}$ & $\geq 50$ & $\begin{array}{r}\text { Circulating PFBC } \\
+ \text { coal pyrolyzer }\end{array}$ & $\begin{array}{c}2600^{\circ} \mathrm{F} \text { turbine } \\
+4,500 \text { psi steam } \\
\text { turbine }\end{array}$ & Hot gas filtration & $\begin{array}{l}\text { In-bed limestone } \\
\text { or dolomite }\end{array}$ & $\begin{array}{c}\text { Combustion } \\
\text { controls } \\
(+ \text { SCR if needed })\end{array}$ \\
\hline IGAC (2010) & $\geq 50$ & $\begin{array}{l}\text { Oxygen- or air-blown } \\
\text { fluidized- } \\
\text { bed gasifier }\end{array}$ & $\begin{array}{c}2600^{\circ} \mathrm{F} \text { gas } \\
\text { turbine (humidified) }\end{array}$ & Hot gas filtration & $\begin{array}{c}\text { Hot gas } \\
\text { desulfurization } \\
+ \text { in-bed } \\
\text { limestone } \\
\text { (optional) }\end{array}$ & $\begin{array}{c}\text { Combustion } \\
\text { controls } \\
(+ \text { SCR if needed })\end{array}$ \\
\hline IGFC (2010) & $\geq 60$ & $\begin{array}{l}\text { Oxygen- or air-blown } \\
\text { fluidized-bed gasifier }\end{array}$ & $\begin{array}{l}\text { Molten carbonate } \\
\text { fuel cell }\left(1200^{\circ} \mathrm{F}\right) \\
\text { +HRSG/turbine }\end{array}$ & Hot gas filtration & $\begin{array}{l}\text { Hot gas } \\
\text { desulfurization } \\
\text { + in-bed } \\
\text { limestone } \\
\text { (optional) }\end{array}$ & $\begin{array}{c}\text { Combustion } \\
\text { controls } \\
(+ \text { SCR if needed })\end{array}$ \\
\hline
\end{tabular}

HRSG, heat recovery steam generator.

ESP, electrostatic precipitator.

FGD, flue gas desulfurization.

SCR, selective catalytic reduction.

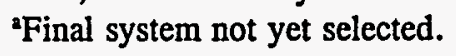


Table 10-2 Strategic Objectives of the DOE Advanced Power Systems Program

\begin{tabular}{lcccc}
\hline & \multicolumn{4}{c}{ Period } \\
\cline { 2 - 5 } Objective & 2000 & 2005 & 2010 & 2015 \\
\hline Efficiency (percent) & 42 & 47 & 55 & 60 \\
Emissions (NSPS) & $1 / 3$ & $1 / 4$ & $1 / 10$ & $1 / 10$ \\
Cost of energy & $10-20$ percent lower than currently available pulverized coal \\
& \multicolumn{4}{c}{ technology } \\
\hline
\end{tabular}

${ }^{2}$ NSPS, New Source Performance Standards. Current federal standards apply to emissions of sulfur dioxide, oxides of nitrogen, and particulates from coal-based steam generators.

Source: DOE (1993a).

Table 10-3 Potential $\mathrm{CO}_{2}$ Reductions for Advanced Power Systems Relative to Current CoalFired Power Plants (percent) ${ }^{\mathrm{a}, \mathrm{b}}$

\begin{tabular}{lcccc}
\hline Basis for Comparison; Efficiency & \multicolumn{4}{c}{ Period } \\
\cline { 2 - 5 } & 2000 & 2005 & 2010 & 2015 \\
\hline Average U.S. plant; 33\% & 21 & 30 & 40 & 45 \\
New U.S. plants; 38\% & 10 & 19 & 31 & 37 \\
New plants worldwide; 42\% & 0 & 11 & 24 & 30 \\
\hline
\end{tabular}

'The numbers in this table show the percent reduction in $\mathrm{CO}_{2}$ from replacing an existing power plant of the indicated efficiency with a more efficient advanced plant that meets the DOE goals in Table 10-2. See Table 10-2 for assumed efficiency improvements for advanced coal technology in each time period.

'A widely used computer model developed by DOE's Battelle Pacific Northwest Laboratories was run to estimate the long-term impacts of meeting DOE's cost and efficiency objectives. The model estimated an overall reduction of about 19 percent in coal use and $\mathrm{CO}_{2}$ emissions from power generation in the year 2050 from introducing DOE's more advanced and lower-cost power systems in the United States, relative to a base case with a much smaller rate of efficiency improvement. These results, of course, depend on a host of other model assumptions and projections besides meeting DOE technology goals. The results are presented simply to indicate that a 30 to 40 percent reduction in $\mathrm{CO}_{2}$ emissions from new plants does not translate into a comparable reduction in overall $\mathrm{CO}_{2}$ emissions even after 35 years. 
Table 10-4 EPACT Requirements and DOE Coal Program Compared ${ }^{2}$

\begin{tabular}{|c|c|c|}
\hline EPACT Requirements & Key Features of DOE Program Activities & Committee Rating and Comments \\
\hline \multicolumn{3}{|c|}{$\begin{array}{l}\text { TITLE XIII-COAL } \\
\text { Subtitle A-Research, Development, Demonstration, and Commercial Application }\end{array}$} \\
\hline Section 1301: Coal Research, Development, Demo & tion, and Commercial $\mathrm{Ap}$ & \\
\hline $\begin{array}{l}\text {-Conduct RDD\&C programs on coal-based } \\
\text { technologies to: } \\
\text { - ensure reliable electricity supply } \\
\text { - comply with environmental regulations } \\
\text { - control emissions } \\
\text { - achieve cost-competitive conversion of coal to } \\
\text { transportation fuels } \\
\text { - demonstrate conversion of coal to synthetic fuels } \\
\text { - ensure timely commercial application of coal } \\
\text { technologies with improved efficiency and }\end{array}$ & $\begin{array}{l}\text {-Advanced clean/efficient power systems: } \\
\text { - advanced pulverized coal-fired power plant, } \\
\text { including low-emission boiler systems } \\
\text { - indirect-fired cycle } \\
\text { - integrated gasification combined-cycle } \\
\text { - pressurized fluidized-bed } \\
\text { - advanced research and environmental technology } \\
\text { (AR\&ET), including hot gas and flue gas cleanup } \\
\text { - magnetohydrodynamics (MHD) }\end{array}$ & $\begin{array}{l}\text { High priority for DOE-adequate level of } \\
\text { effort (see text for discussion and } \\
\text { priorities) } \\
\text { See below, also under Section 1301, } \\
\text { Advanced Research, for comments on } \\
\text { AR\&ET. } \\
\text { See Section } 1311 \text { for comments on MHD } \\
\text { program. }\end{array}$ \\
\hline
\end{tabular}

$\sim$ emissions control

$\widetilde{\infty}$ - ensure availability of technologies for commercial

use by 2010

'This summary of DOE program activities is based on planning documents provided by DOE's Office of Fossil Energy, the DOE FY 1994 budget, the FY 1995 congressional budget request, and presentations to the committee by DOE staff (see Appendix F). 
Table 10-4 EPACT Requirements and DOE Coal Program Compared (Continued)

\begin{tabular}{|c|c|c|}
\hline EPACT Requirements & Key Features of DOE Program Activities & Committee Rating and Comments \\
\hline \multirow{3}{*}{ 용 } & $\begin{array}{l}\text {-Advanced clean fuels (see also Section 1312): } \\
\text { - direct liquefaction } \\
\text { - indirect liquefaction } \\
\text { - coal preparation } \\
\text { - AR\&ET }\end{array}$ & $\begin{array}{l}\text { High priority for DOE-additional effort } \\
\text { recommended } \\
\text { - Focused program on high-efficiency } \\
\text { gasification needed } \\
\text {-Increased emphasis on liquefaction } \\
\text { recommended (see Section 1312) } \\
\text {-Continue current limited effort in coal } \\
\text { preparation. }\end{array}$ \\
\hline & $\begin{array}{l}\text {-Advanced research (Advanced Research and } \\
\text { Technology Demonstration, plus specific } \\
\text { technologies for fuels and power systems), with } \\
\text { major activities including: } \\
\text { - coal utilization science } \\
\text { - materials and components } \\
\text { - university/national laboratory coal research } \\
\text { - coal liquefaction }\end{array}$ & $\begin{array}{l}\text { High priority for DOE-additional effort } \\
\text { recommended } \\
\text {-The balance between short- and long- } \\
\text { term activities within the FE coal R\&D } \\
\text { program should be reassessed, based on } \\
\text { strategic planning extending beyond } \\
\text { 2010. (See text for discussion.) }\end{array}$ \\
\hline & $\begin{array}{l}\text { - Clean Coal Technology (CCT) demonstration } \\
\text { projects }\end{array}$ & $\begin{array}{l}\text { High priority for DOE-adequate level of } \\
\text { effort } \\
\text { - Commercial acceptance of clean coal } \\
\text { technologies may not occur in the } \\
\text { proposed period without further cost } \\
\text { sharing of technical and financial risk. }\end{array}$ \\
\hline
\end{tabular}




\section{Section 1302: Coal-Fired Diesel Engines}

- Conduct RDD\&C program for utilization of coalderived liquid or gaseous fuels, including ultra-clean CWSs (coal-water slurries) in diesel engines.
-See Section 1301 for gaseous and liquid fuels. -Coal-fired diesel program (Direct Coal-Fired Heat Engines activity) was completed in FY 1993. -Coal-fired diesel engine to be demonstrated in CCT-V.

- Under DOE contract, Riley Research conducted tests in circulating atmospheric fluidized bed on cofiring of coal with de-inking paper sludge and high-Btu ash.

-DOE sponsored pilot-scale work on cofiring of coal and infectious hospital waste; subsequent demonstration in Lebanon, Pennsylvania, will involve 50 percent $\mathrm{DOE}$ cost share.

-DOE has assessed technical and economic feasibility of direct liquefaction of coal with hydrocarbon- or paper-based wastes to produce premium transportation fuels; follow-up program proposed.
Low priority for $D O E$-inactive -Coal-derived liquids and gaseous fuels do not differ significantly from conventional diesel fuels; no separate DOE-funded study required. -DOE program on coal-fired diesels has been carried through to an appropriate level; no justification for further activity because of unfavorable economics and potentially insurmountable environmental issues.

\section{Adequate level of DOE effort}

-Gasification system approach best addressed by private sector - Minimal DOE participation required for hospital waste program. No major R\&D issues to be addressed; requires additional stack cleanup.

Waste methane-see Section 1306 
Table 10-4 EPACT Requirements and DOE Coal Program Compared (Continued)

\begin{tabular}{|c|}
\hline EPACT Requirements \\
\hline Section 1304: Nonfuel Use of Coal ${ }^{b}$ \\
\hline $\begin{array}{l}\text {-Plan and carry out RDD\&C program for nonfuel } \\
\text { use of coal, including: } \\
\text { - production of coke and other carbon-based } \\
\text { products, chemicals, and chemical feedstocks from } \\
\text { coal } \\
\text { - chemicals from synthesis gas } \\
\text { - utilization of wastes from coal (see Section 1308) } \\
\text { - Above program should include assessment of } \\
\text { economic feasibility of coproduction, refining, and } \\
\text { utilization of coal-based products (see Section 1305) }\end{array}$ \\
\hline Section 1305: Coal Refinery Program \\
\hline $\begin{array}{l}\text { - Conduct RDD\&C program for coal refining } \\
\text { technologies for high-sulfur coals, low-sulfur coals, } \\
\text { subbituminous coals, and lignites to produce } \\
\text { transportation fuels, compliance boiler fuels, fuel } \\
\text { additives, lubricants, and chemical feedstocks, alone } \\
\text { or with power generation. }\end{array}$ \\
\hline
\end{tabular}

Key Features of DOE Program Activities

Committee Rating and Comments

-Syngas production activity supports concept development for coproduction of coal-derived fuels and chemicals in conjunction with electric power (see Section 1312, indirect liquefaction).

-Mild gasification/coal refinery activities address production of coke and chemical intermediates (see also Sections 1305 and 1312).

-DOE supporting Carbon Products Consortium in development of coal-based alternative feedstocks and establishment of links with industry. No further funding requested for FY 1995.

- Coal refinery activity included under advanced clean fuels research (Section 1312) addresses coproduction of electricity and coal liquids.

-Mild gasification is part of ongoing CCT program.
-See Section 1312

\section{Low priority for $D O E$}

- Decreasing market for coke

- CCT program on mild gasification adequate (see Section 1305)

Low priority for $D O E$

\section{High priority for $D O E$}

-Worthwhile concept; systems assessments have indicated promising areas, especially coproduction of syngas liquids with electricity.

- Further assessments needed to identify and exploit opportunities.

\section{Low priority for $D O E$}

-Adequately covered by CCT program.

${ }^{b}$ The committee notes that DOE programs responding to Section 1304 include fuel and nonfuel uses of coal. 
Table 10-4 EPACT Requirements and DOE Coal Program Compared (Continued)

\begin{tabular}{|c|c|c|}
\hline EPACT Requirements & Key Features of DOE Program Activities & Committee Rating and Comments \\
\hline \multicolumn{3}{|l|}{ Section 1306: Coalbed Methane Recovery } \\
\hline $\begin{array}{l}\text { - Conduct a study of barriers and environmental } \\
\text { safety aspects. } \\
\text { - Disseminate information to public on state-of-the- } \\
\text { art technologies. } \\
\text { - Conduct coalbed methane demonstration and } \\
\text { commercial application program }\end{array}$ & $\begin{array}{l}\text { - Previous DOE program ended in } 1993 . \\
\text {-Clinton administration's Climate Change Action } \\
\text { Plan (CCAP) establishes new initiatives to reduce } \\
\text { methane emissions from all major sources, including } \\
\text { coal mines (Clinton and Gore, 1993). } \\
\text {-DOE FY } 1994 \text { budget request for } \$ 300 \mathrm{~K} \text { for } \\
\text { coalbed methane activities was not approved; FY } \\
1995 \text { budget request covers coalbed methane } \\
\text { recovery under natural gas program. } \\
\text {-CCAP requires DOE and EPA to create Coalbed } \\
\text { Methane Outreach program-currently no activity } \\
\text { due to lack of funding. } \\
\text {-CCAP requires expansion of DOE RD\&D } \\
\text { programs for methane recovery from coal mining; } \\
\text { interaction with stakeholders initiated in } 1993 \\
\text { continues. }\end{array}$ & $\begin{array}{l}\text { Low methane concentration }(<1.0 \%) \\
\text { Moderate priority for } D O E \\
\text {-There are possible low-level R\&D } \\
\text { activities investigating separation and } \\
\text { combustion processes for dilute methane. } \\
\text { Higher methane concentrations } \\
\text { Low priority for DOE } \\
\text { - Existing commercial technology } \\
\text { adequate but in limited use. }\end{array}$ \\
\hline \multicolumn{3}{|l|}{ Section 1307: Metallurgical Coal Development } \\
\hline $\begin{array}{l}\text {-Establish RDD\&C program for use of metallurgical } \\
\text { coal as: } \\
\text { - a boiler fuel } \\
\text { - an ingredient in steel manufacture } \\
\text { - source of coalbed methane }\end{array}$ & $\begin{array}{l}\text {-DOE not currently conducting any research specific } \\
\text { to metallurgical coal development. } \\
\text {-Information on gas content in } 16 \text { U.S. coal basins } \\
\text { available in METC database. } \\
\text { - Commercial technology exists to burn metallurgical } \\
\text { coal as boiler fuel or use in steelmaking. }\end{array}$ & $\begin{array}{l}\text { Low priority for DOE-inactive } \\
\text {-No new technology needed to burn as } \\
\text { boiler fuel. } \\
\text {-Activities relating to metallurgical coal } \\
\text { as a source of coalbed methane should } \\
\text { be included in Section } 1306 \text { programs. }\end{array}$ \\
\hline
\end{tabular}


Table 10-4 EPACT Requirements and DOE Coal Program Compared (Continued)

\begin{tabular}{|c|c|c|}
\hline EPACT Requirements & Key Features of DOE Program Activities & Committee Rating and Comments \\
\hline \multicolumn{3}{|l|}{ Section 1308: Utilization of Coal Wastes } \\
\hline $\begin{array}{l}\text {-Establish RDD\&C program for utilization of coal } \\
\text { wastes from mining and processing, including as a } \\
\text { boiler fuel. }\end{array}$ & $\begin{array}{l}\text {-AR\&ET program on waste management includes } \\
\text { examination of technical and economic aspects of } \\
\text { waste utilization technology }\end{array}$ & $\begin{array}{l}\text { Low priority for DOE-inactive } \\
\text {-Technology is commercial-possible } \\
\text { limited DOE role in economic and } \\
\text { technical assessment. } \\
\text { - Application of past DOE work on } \\
\text { fluidized-bed combustion now being } \\
\text { handled by industry. }\end{array}$ \\
\hline \multicolumn{3}{|l|}{ Section 1309: Underground Coal Gasification } \\
\hline $\begin{array}{l}\text { • Conduct RDD\&C program for in situ conversion of } \\
\omega \\
\omega \\
\text { coal to an easily transportable gaseous fuel. }\end{array}$ & $\begin{array}{l}\text {-DOE program ended in FY } 1991 \text {. Sufficient } \\
\text { technical, operational, and environmental parameters } \\
\text { developed to allow industry to make necessary } \\
\text { decisions regarding commercialization. }\end{array}$ & $\begin{array}{l}\text { Low priority for DOE-inactive } \\
\text {-In agreement with current DOE } \\
\text { assessment that underground gasification } \\
\text { will not result in a competitive gaseous } \\
\text { fuel. }\end{array}$ \\
\hline \multicolumn{3}{|l|}{ Section 1310: Low-Rank Coal Research and Development } \\
\hline $\begin{array}{l}\text {-Pursue R\&D program to expand use of low-rank } \\
\text { coals in high-value-added carbon products, fuel } \\
\text { cells, coal-water fuels, distillates, and other niche } \\
\text { market applications. }\end{array}$ & $\begin{array}{l}\text {-Research effort on low-rank coals sponsored by } \\
\text { DOE at University of North Dakota Energy and } \\
\text { Environmental Research Center (UNDEERC). } \\
\text { - Consortium being formed under UNDEERC } \\
\text { leadership to demonstrate production of low-rank } \\
\text { coal water fuels from Alaskan coals. }\end{array}$ & $\begin{array}{l}\text { No special effort required aimed at low- } \\
\text { rank coals } \\
\text { - Low-rank coals are included in general } \\
\text { coal utilization program (Section 1301) } \\
\text { and represent one end of a continuum of } \\
\text { materials. }\end{array}$ \\
\hline
\end{tabular}




\section{Section 1311: Magnetohydrodynamics (MHD)}

- Carry out RDD\&C program to determine adequacy of engineering and design information completed to date under DOE sponsorship.

-Issue solicitations to fulfill above objective.
-Conducting proof-of-concept program closeout -No solicitations issued

Documentation and cleanup activities-high priority for DOE - Need for thorough documentation of past work: current plans for this activity insufficient.

MHD system development-low priority for $D O E$

-MHD does not appear to offer significant advantages over other advanced high-efficiency systems. - Next step in development involves very expensive demonstration program, since technical risk cannot be broken down.

\section{Nection 1312: Oil Substitution Through Coal Liquefaction ${ }^{c}$}

-Conduct RDD\&C program to develop economically and environmentaily acceptable advanced

technologies for oil substitution through coal

- Direct liquefaction, including advanced liquefactio processes, coprocessing with waste materiais, and innovative process concepts

liquefaction. Program goals are to include:

- improved resource selection and product quality

- increased net yield

- increased overall thermal efficiency

- reduced capital and operating costs

\section{High priority for $D O E$}

-DOE should maintain an active

program since industry activity in this area is declining.

-Innovative approaches should be encouraged.

- Large pilot and demonstration plants not required at this time.

'See also committee ratings and comments on advanced clean fuels research under Section 1301. 
Table 10-4 EPACT Requirements and DOE Coal Program Compared (Continued)

\begin{tabular}{|c|c|c|}
\hline EPACT Requirements & Key Features of DOE Program Activities & Committee Rating and Comments \\
\hline & $\begin{array}{l}\text {-Indirect liquefaction, including Fischer-Tropsch } \\
\text { chemistry, catalyst development, reactor design, } \\
\text { oxygenate catalyst research, syngas, and low-cost } \\
\text { hydrogen production }\end{array}$ & $\begin{array}{l}\text { High priority for DOE } \\
\text { - Opportunities for coproduction with } \\
\text { electricity (see Section 1305). } \\
\text { - Need coordination with active industry } \\
\text { programs for natural gas conversion; } \\
\text { DOE should focus on applying this } \\
\text { technology to coal. }\end{array}$ \\
\hline & $\begin{array}{l}\text {-Mild gasification/coal refinery activity, including } \\
\text { systems for coproducts (overlap with Section 1305) }\end{array}$ & -See Section 1305 \\
\hline \multicolumn{3}{|l|}{ 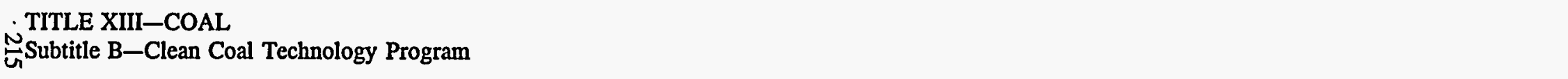 } \\
\hline \multicolumn{3}{|c|}{ Section 1321: Additional Clean Coal Technology Solicitations } \\
\hline $\begin{array}{l}\text { - Conduct additional solicitations for development of } \\
\text { cost-effective, higher-efficiency, low-emission coal } \\
\text { utilization technologies, with emphasis on need for } \\
\text { commercialization by } 2010 \text {. }\end{array}$ & $\begin{array}{l}\text {-In response to request from Secretary for Energy, } \\
\text { the National Coal Council prepared a report (NCC, } \\
\text { 1994) addressing future directions for the CCT } \\
\text { program. } \\
\text {-DOE report, Clean Coal Technology-Completing } \\
\text { the Mission, released 05/06/94 (DOE, 1994c). } \\
\text { - No additional solicitations issued beyond CCT-V. } \\
\text { Proposed diversion of CCT funds to overseas } \\
\text { demonstration projects. }\end{array}$ & $\begin{array}{l}\text { High priority for DOE-future action } \\
\text { requires consideration (see text for } \\
\text { discussion) } \\
\text {-Emphasis should be on deployment of } \\
\text { technologies developed and demonstrated } \\
\text { in earlier rounds. } \\
\text {-Commercial acceptance of CCT } \\
\text { technologies may require further cost } \\
\text { sharing of technical and financial risk. }\end{array}$ \\
\hline
\end{tabular}


Table 10-4 EPACT Requirements and DOE Coal Program Compared (Continued)

\begin{tabular}{lll}
\hline EPACT Requirements & Key Features of DOE Program Activities & Committee Rating and Comments \\
\hline
\end{tabular}

TITLE XIII-COAL

Subtitle C-Other Coal Provisions

Section 1332: Innovative Clean Coal Technology Transfer Program

- Develop joint DOE/Agency for International Development clean coal technology transfer program to encourage exports of U.S. technologies that allow more efficient, cost-effective, and environmentally acceptable use of coal resources.

N⿳亠口冋

\section{Section 1336: Coal Fuel Mixtures}

-Prepare a report on technical and economic feasibility, development status, market potential, and commercialization barriers to combining coal with other materials, such as oil and water fuel mixtures.

\section{Section 1337: National Clearinghouse}

-Assess feasibility of establishing national clearinghouse for exchange and dissemination of information on technology relating to coal and coalderived fuels.
- Solicitations for China and Eastern Europe

"showcase" projects to be outlined in FY 1994.

- Public meeting on Clean Coal International

Technology Transfer Program held February 1994.

- NCC report (see Section 1321) includes advice on conducting international technology transfer effort.

- Coal preparation program (Advanced Clean Fuels Research) includes superclean coal water slurry (SCCWS) project (formerly part of Alternative Fuels Program).

- No current DOE activities; DOE is awaiting recommendations from National Research Council.
Low priority for DOE compared to domestic program

- Current funds probably insufficient to meet requirements of Sections 1321 and 1332.

-Priority should be given to Section 1321 requirements emphasizing CCT deployment in domestic market.

Low priority for $D O E-$ previous assessments adequate

-Technologies for this very specialized market have been effectively commercialized and utilized.

- Need for national clearinghouse should be established by market survey of potential users.

-Any activity should involve participants from inside and outside DOE.

- External committee should assess feasibility of concept and make recommendations for implementation. 
Table 10-4 EPACT Requirements and DOE Coal Program Compared (Continued)

\begin{tabular}{|c|c|c|}
\hline EPACT Requirements & Key Features of DOE Program Activities & Committee Rating and Comments \\
\hline \multicolumn{3}{|c|}{$\begin{array}{l}\text { TITLE XX-GENERAL PROVISIONS; REDUCTION OF OIL VULNERABILITY } \\
\text { Subtitle A-Oil and Gas Supply Enhancement }\end{array}$} \\
\hline \multicolumn{3}{|l|}{ Section 2013: Natural Gas Supply } \\
\hline $\begin{array}{l}\text { - Conduct five-year program to increase recoverable } \\
\text { natural gas resource base by more intensive recovery } \\
\text { from discovered conventional resources; extraction } \\
\text { from unconventional sources; surface gasification of } \\
\text { coal; and recovery of methane from biofuels. }\end{array}$ & $\begin{array}{l}\text {-METC Surface Coal Gasification Program involves } \\
\text { R\&D on new concepts development and refinement } \\
\text { of existing systems. }\end{array}$ & $\begin{array}{l}\text { Methanation aspect of SNG } \\
\text { production-low priority for DOE } \\
\text { Gasification-high priority for DOE (see } \\
\text { Section 1301) }\end{array}$ \\
\hline $\begin{array}{l}\text { with coal in utility and large industrial boilers. } \\
\text { wastion }\end{array}$ & $\begin{array}{l}\text { - Cofiring of natural gas with coal addressed in CCT } \\
\text { program. }\end{array}$ & $\begin{array}{l}\text { Low priority for DOE-appropriate level } \\
\text { of effort } \\
\text { - Established technology for pulverized } \\
\text { coal } \\
\text {-CCT program activity adequate. }\end{array}$ \\
\hline
\end{tabular}




\title{
Appendix A \\ Project Description \\ Strategic Assessment of DOE's Coal Program
}

For Public Release

August 18, 1993

\section{NATIONAL ACADEMY OF SCIENCES-NATIONAL RESEARCH COUNCIL COMMISSION ON ENGINEERING AIND TECHNICAL SYSTEMS ENERGY ENGINEERING BOARD}

\author{
STRATEGIC ASSESSMENT OF \\ THE DEPARTMENT OF ENERGY'S COAL PROGRAM
}

\section{INTRODUCTION:}

The Energy Policy Act of 1992 (EPACT) gives certain responsibilities to the Secretary of Energy pertaining to DOE's coal program. EPACT further requires the Secretary to submit reports to the Congress on the program, including a plan for Research, Development, Demonstration, and Commercial Application (RDD\&C) to meet the objectives/defined in Title XIII, Section 1301. Other sections in Subtitle A identify specific technologies or areas that the U.S. Department of Energy should address under this RDD\&C program. In addition to Subtitle A, Subtitles B and C in Title XII and Subtitle A in Title XX, also identify other coal-related activities in the areas outlined below for implementation by the DOE.

\section{TITLE XIII COAL}

Subtitle A: Research, Development, Demonistration, and Commercial Application:

-- Section 1301: RDD\&C Program on Coal Conversion and Utilization Technologies;

-- Section 1302: Coal-fired Diesel Engines;

-- Section 1303: Clean Coal, Waste-to Energy;

-- Section 1304: Nonfuel Use of Coal; 
-- Section 1305: Coal Refinery Program;

-- Section 1306: Coalbed Methane Recovery

-- Section 1307: Metallurgical Coal Development;

-- Section 1308: Utilization of Coal Wastes;

-- Section 1309: Underground Coal Gasification;

-- $\quad$ Section 1310: Low Rank Coal Research and Development;

-- Section 1311: Magnetohydrodynamics;

-- Section 1312: Oil Substitution Through Coal Liquefaction.

Subtitle B (Clean Coal Technology Program):

-- Section 1321: Additional Clean Coal Technology Solicitations

Subtitle C: Other Coal Provisions:

-- Section 1332: Innovative Clean Coal Technology Transfer Program;

-. $\quad$ Section 1336: Coal Fuel Mixtures;

-- Section 1337: National Clearinghouse.

\section{TITLE XX GENERAL PROVISIONS; REDUCTION OF OIL VULNERABILITY}

\section{Subtitle A: Oil and Gas Supply Enhancement:}

-- Section 2013: Natural Gas Supply

-- $\quad$ Subsections dealing with surface gasification of coal, and cofiring of natural gas and coal.

Section 1301 requires that the Secretary of Energy submit a report to the Congress to achieve the objectives defined in this section, including "ensuring reliable electricity supply, complying with applicable environmental requirements, achieving cost-competitive production and demonstration of liquid and gaseous fuels from coal, and ensuring the timely commercial application of cost-effective coal technologies." In particular, subparagraphs $c(1)$ to $c(5)$ of Section 1301 call for this report to include the following information:

-- $\quad$ Subparagraph c(1): A detailed description of ongoing RDD\&C activities regarding coalbased technologies undertaken by DOE, other Federal or State government departments or agencies and, to the extent such information is publicly available, other public or private organizations in the United States and other countries.

-- Subparagraph c(2): A listing and analysis of current Federal and State government regulatory and financial incentives that could further the goals of the programs established under Subtitle A.

-- Subparagraph c(3): Recommendations regarding the manner in which any ongoing coalbased demonstration and commercial application program might be modified and extended to ensure the timely demonstrations of advanced coal-based technologies.

-- $\quad$ Subparagraph c(4): Recommendations, if any, regarding the manner in which the cost sharing demonstrations conducted pursuant to the Clean Coal Program established by 
Public Law 98-473 might be modified and extended in order to ensure the timely demonstration of advanced coal-based technologies.

- Subparagraph c(5): A detailed plan for conducting the research, development, demonstration, and commercial application programs to achieve the goals and objectives defined in Section 1301.

The DOE has been conducting coal RD\&D programs for many years. These programs have addressed, or are addressing, some of the areas identified in EPACT. The Office of Fossil Energy's coal programs are described in the document entitled "Coal Strategic Plan" and in the Administration's budget request for fiscal year (FY) 1994. Beginning in FY 1994, the Office of Fossil Energy will begin to update its "Coal Strategic Plan," and formulate the RDD\&C plan required by Section 1301. As part of this process, the Office of Fossil Energy is seeking the advice and recommendations of the National Research Council regarding strategy and priorities in its coal program.

\section{PROPOSED ACTIVITY:}

The Energy Engineering Board (EEB) will establish a committee to review DOE's current coal program, and selected sections of EPACT relating to coal, and develop recommendations to update the "Coal Strategic Plan." The committee will include about 10 members from disciplines pertinent to the proposed effort. Expertise will be sought in areas such as coal science, conversion of coal to gaseous and liquid fuels, especially coal gasification, coal-based electricity generation, chemical engineering, energy engineering, environmental control technologies, energy economics, and strategic planning for $\mathrm{R} \& \mathrm{D}$. The committee will provide independent scientific and technical advice consistent with the strategic assessment requested by the DOE targeted at the planning cycle beginning with FY 1996. In the process of nominating the committee and during the course of the study, as appropriate, the EEB will consult with other NRC units including the Board on Earth Sciences and Resources and the Board on Chemical Sciences and Technology. The committee will be subject to the usual NRC bias and conflict of interest procedures.

The committee will:

- Review the DOE coal program including the current version of the "Coal Strategic Plan" and additional details contained in the Administration's budget requests for FY 1994 and 1995, as appropriate.

- Review the sections identified above in EPACT, especially Section 1301, and the status of the DOE coal program vis-a-vis the provisions in the EPACT and coal related R\&D in organizations outside DOE.

- Recommend objectives (including performance and schedule) that ought to be emphasized for those areas in EPACT that are not in the current DOE coal program. 
- Make recommendations pertaining to Section 1301 (c), especially subparagraphs c(3), $c(4)$, and $c(5)$ :

-- As part of this task, DOE's Office of Fossil Energy will provide the committee early in the study with the Office's own, strategically focused descriptions of its ongoing research, development, demonstration, and commercial application activities, and the listing and analysis of current government regulatory and financial incentives described in subparagraphs $c(1)$ and $c(2)$, respectively. The Office will also provide for the committee's consideration its evaluations of requirements in several areas related to EPACT provisions (e.g., nonfuel uses of coal, coal refining).

- Identify priorities for DOE's future coal program areas based on the foregoing reviews and recommendations and the assumption that the outyear budgets (to be appropriated) for the DOE coal program remain at the FY 1994 level (in real terms).

- Prepare a report that would include, in broad strategic terms, the emphasis and priorities that DOE ought to consider in updating its "Coal Strategic Plan" and responding to the EPACT.

The committee will have an initial orientation and planning meeting to set the terms of reference for the study. The Office of Fossil Energy will brief the committee on its expectations of the study, on its Coal Strategic Plan, coal-related provision in EPACT, the current DOE coal program, and preliminary strategies and plans for new initiatives.

The committee will invite a number of outside experts to brief it at its second meeting. The objective of this meeting will be to solicit information and opinion from a variety of sources in industry, universities, national laboratories and, as appropriate, other public and private sector organizations that have an interest in the DOE coal program. The meeting will be directed at a critical assessment of the current DOE coal program and areas in EPACT identified above for which the DOE is seeking programmatic objectives and priorities.

The committee will hold additional deliberative meetings to formulate its conclusions and recommendations and prepare its report.

It is anticipated that the study will begin about August 1, 1993, and the committee's report would be available by July 31, 1994.

\section{ANTICIPATED RESULTS:}

The study will result in a final report to the Department of Energy responsive to the charge outlined in this proposal. The committee's report will be subject to NRC review procedures and be made available to the public without restrictions. The report will be prepared in sufficient quantity to ensure adequate distribution. 


\title{
Appendix B
}

\author{
The Energy Policy Aict of 1992
}

\section{TITLE XIII-COAL}

\section{Subtitle A-Research, Development, Demonstration, and Commercial Application}

SEC. 1301. COAL RESEARCH. DEVELOPHENT, DEHONSTRATION, AND COH. MERCIAL APPLICATION PROGRA HS.

(a) EstaBLISHMENT. - The Secretary shall, in accordance with section 3001 and 3002 of this Act, conduct programs for research, development, demonstration, and commercial application on coalbesed technologies. Such research, development, demonstration, and commercial application programs shall include the programs established under this subtitle, and shall have the goals and objectives of-

(1) ensuring a reliable electricity supply;

(2) complying with applicable environmental requirements;

(3) achieving the control of sulfur oxides, oxides of nitrogen. air toxics, solid and liquid wastes, greenhouse gases, or other emissions resulting from coal use or conversion at levels of proficiency greater than or equal to applicable currently available commercial technology:

(4) achieving the cost competitive conversion of coal into energy forms usable in the transportation sector:

(5) demonstrating the conversion of coal to synthetic gaseous, liguid. and solid fuels:

(6) demonstrating, in cooperation with other Federal and State agencies, the use of coal-derived fuels in mobile equipment, with opportunities for industrial cost sharing participa. tion; 
(7) ensuring the timely commercial application of cost-effective technologies or energy production processes or systems utilizing coal which achieve-

(A) greater efficiency in the conversion of coal to useful energy when compared to currently available commercial technology for the use of coal; and and

(B) the control of emissions from the utilization of coal;

(8) ensuring the availability for commercial use of such technologies by the year 2010.

(b) DEMONSTRATION AND COMMERCIAL APPLICATION PROGRAMS. - (1) In selecting either a demonstration project or a commer. cial application project for financial assistance under this subtitle, the Secretary shall seek to ensure that, relative to otherwise compa. rable commercially available technologies or products, the selected project will meet one or more of the following criteria:

(A) It will reduce environmental emissions to an extent greater than required by applicable provisions of law.

(B) It will increase the overall efficiency of the utilization of coal, including energy conversion efficiency and, where applicable, production of products derived from coal.

(C) It will be a more cost-effective technological alternative. based on life cycle capital and operating costs per unit of energy produced and, where applicable, costs per unit of product pro. duced.

Priority in selection shall be given to those projects which, in the judgment of the Secretary, best meet one or more of these criteria. (2) In administering demonstration and commercial application programs authorized by this subtitle, the Secretary shall establish accounting and project management controls that will be adequate to control costs.

(3XA) Not later than 180 days after the date of enactment of this Act, the Secretary shall establish procedures and criteria for the recoupment of the Federal share of each cost shared demonstration and commercial application project authorized pursuant to this subtitle. Such recoupment shall occur within a reasonable period of time following the date of completion of such project, but not later than 20 years following such date, taking into account the effect of recoupment on-

(i) the commercial competitiveness of the entity carrying out the project;

(ii) the profitability of the project; and utilized.

(iii) the commercial viability of the coal-based technology

(B) The Secretary may at any time waive or defer all or some portion of the recoupment requirement as necessary for the commer. cial viability of the project.

(4) Projects selected by the Secretary under this subtitle for dem. onstration or commercial application of a technology shall, in the judgment of the Secretary, be capable of enhancing the state of the art for such technology.

(c) REPORT. - Within 240 days after the date of enactment of this Act, the Secretary shall transmit to the Committee on Energy and Commerce and the Committee on Science, Space, and Technolo- 
206

gy of the House of Representatives and to the Committee on Energy and Natural Resources of the Senate a report which shall include each of the following:

(1) A detailed description of ongoing research, development, demonstration and commercial application activities regarding coal-based technologies undertaken by the Department of Energy, other Federal or State government departments or agencies and, to the extent such information is publicly available, other public or private organizations in the United States and other countries.

(2) A listing and analysis of current Federal and State government regulatory and financial incentives that could further the goals of the programs established under this subtitle.

(3) Recommendations regarding the manner in which any ongoing coal-based demonstration and commercial application program might be modified and extended in order to ensure the timely demonstrations of advanced coal-based technologies so as to ensure that the goals established under this section are achieved and that such demonstrated technologies are available for commercial use by the year 2010 .

(4) Recommendations, if any, regarding the manner in which the cost sharing demonstrations conducted pursuant to the Clean Coal Program established by Public Law 98-473 might be modified and extended in order to ensure the timely demonstration of advanced coal-based technologies.

(5) A detailed plan for conducting the research, develop. ment. demonstration, and commercial application programs to achiece the goals and objectives of subsection (a) of this section, which plan shall include a description of-

(A) the program elements and management structure to be utilized;

$(B)$ the technical milestones to be achieved with respect to each of the advanced coal-based technologies included in the plan; and

(C) the dates at which further deadlines for additional cost sharing demonstrations shall be established.

(d) STATUS REPORTS. - Within one year after transmittal of the report described in subsection (c), and every 2 years thereafter for a period of 6 years, the Secretary shall transmit to the Congress a report that provides a detailed description of the status of development of the advanced coal-based technologies and the research, development, demonstration, and commercial application activities undertaken to carry out the programs required by this subtitle.

(e) Covisultatrov. - In carrying out research, development, demonstration, and commercial application activities under this subtitle, the Secretary shall consult with the National Coal Council and other representatives of the public and private sectors as the Secretary considers appropriate.

SEC. 1302. COALFIRED DIESEL ENGINES.

The Secretary shall conduct a piogram of research, development, demonstration, and commercial application for utilizing coalderived liquid or gaseous fuels, including ultra-clean coal-water slurries, in diesel engines. The program shall address- 
(1) required engine retrofit technology;

(2) coal-fuel production technology;

(3) emission control requirements;

(4) the testing of low-Btu highly reactive fuels;

(5) fuel delivery and storage systems requirements; and

(6) other infrastructure required to support commercial deployment.

SEC. 1303. CLEA.V COAL, WASTE-TO-E.VERGY.

The Secretary shall establish a program of research, development, demonstration, and commercial application with respect to the use of solid waste combined with coal as a fuel source for clean coal combustion technologies. The program shall cidress-

(1) the feasibility of cofiring coal and used vehicle tires in fluidized bed combustion units;

(2) the combined gasification of coal and municipal sludge using integrated gasification combined cycle technology;

(3) the creation of fuel pellets combining coal and material reclaimed from solid waste;

(4) the feasibility of cofiring, in fluidized bed combuistion units, waste methane from coal mines, including ventilation air, together with coal or coal wastes; and

(5) other sources of waste and coal mixtures in other applications that the Secretary considers appropriate.

SEC. 1301. NO.NFLEL LSE OF CO.AL

(a) Progra.14. - The Secretary shall prepare a plan for and carry out a program of research, development, demonstration, and commercial application with respect to technologies for the nonfuel use of coal, including-

(1) production of coke and other carbon products derived from coal;

(2) production of coal-derived, carbon-based chemical intermediates that are precursors of value-added chemicals and polymers;

(3) production of chemicals from coal-derived synthesis gas;

(4) coal treatment processes, including methodologies such as solvent-extraction techniques that produce low ash, low sulfur, coal-based chemical feedstocks; and

(5) waste utilization, including recovery, processing, and marketing of products derived from sulfur, carbon dioxide, nitrogen, and ash from coal.

(b) Plan Contents. - The plan described in subsection (a) shall address and evaluate-

(1) the known and potential processes for using coal in the creation of products in the chemical, utility, fuel, and carbonbased materials industries;

(2) the costs, benefits, and economic feasibility of using coal products in the chemical and materials industries, including value-added chemicals, carbon-based products, coke, and waste derived from coal;

(3) the economics of coproduction of products from coal in conjunction with the production of electric power, thermal energy, and fuel; 
(4) the economics of the refining of coal and coal byproducts to produce nonfuel products;

(5) the economics of coal utilization in comparison with other feedstocks that might be used for the same purposes;

(6) the steps that can be taken by the public and private sectors to bring about commercializalion of technologies developed under the program recommended; and

(7) the past development. current status, and future potential of coal products and processes associated with nonfuel uses of coal.

SEC. 1305. COAL REFINERY PROGRAM.

(a) Program.-The Secretary shall conduct a program of research, development, demonstration, and commercial application for coal refining technologies.

(b) OBJECTIVES. - The program shall include technologies for refining high sulfur coals, low sulfur coals, sub-bituminous coals, and lignites to produce clean-burning transportation fuels, compliance boiler fuels, fuel additives, lubricants, chemical feedstocks, and carbon-based manufactured products, either alone or in conjunction with the generation of electricity or process heat, or the manufacture of a variety of products from coal. The objectives of such program shall be to achieve-

(1) the timely commercial application of technologies, including mild gasification, hydrocracking and other hydropyro. lysis processes, and other energy production processes or systems to produce coal-derived fuels and coproducts, which achieve greater efficiency and economy in the conversion of coal to electrical energy and coproducts than currently available technolo. gy;

(2) the production of energy, fuels, and products which, on a complete energy system basis, will result in environmental emissions no greater than those produced by existing compara. ble energy systems utilized for the same purpose;

(3) the capability to produce co range of coal-derived trans. portation fuels, including oxygenated hydrocarbons, boiler fuels, turbine fuels, and coproducts, which can reduce dependence on imported oil by displacing conventional petroleum in the trans. portation sector and other sectors of the economy;

(4) reduction in the cost of producing such coal-derived fuels and coproducts;

(5) the control of emissions from the combustion of coal-derived fuels; and

(6) the availability for commercial use of such technologies - by the year 2000.

SEC. 1306. COALBED .HETHANE RECOVERY.

- (a) STUDY OF BARRIERS AND ENVIRONMENTAL AND SAFETY AS. PECTS. - The Secretary, in consultation with the Administrator of the Environmental Protection Agency and the Secretary of the Interior, shall conduct a study of -

(1) technical, economic, financial, legal, regulatory, institutional, or other barriers to coalbed methane recovery, and of policy options for eliminating such barriers; and 
(2) the environmental and safety aspects of flaring coalbed methane liberated from coal mines.

Within two years after the date of enactment of this Act, the Secretary shall submit a report to the Congress detailing the results of such study.

(b) INFORMATION DISSEMINATION.-Beginning one year after the date of enactment of this Act, the Secretary, in consultation with the Administrator of the Environmental Protection Agency and the Secretary of the Interior, shall disseminate to the public informa. tion on state-of-the-art coalbed methane recovery techniques, including information on costs and benefits.

(c) Demonstration aNd COMmerCial application PROGRam.The Secretary, is consultation with the Administrator of the Envi. ronmental Protection Agency and the Secretary of the Interior, shall establish a coalbed methane recovery demonstration and commer. cial application program, which shall emphasize gas enrichment technology. Such program shall address-

(1) gas enrichment technologies for enriching medium-qual. ity methane recovered from coal mines to pipeline quality;

(2) technologies to use mine ventilation air in nearby power generation facilities, including gas turbines, internal combustion engines, or other coal fired powerplants;

(3) technologies for cofiring methane recovered from mines, including methane from ventilation systems and degasification systems, together with coal in conventional or clean coal technology boilers; and

(4) other technologies for producing and using methane from coal mines that the Secretary considers appropriate.

SEC. 1307. HETALLURGICAL COAL DEVELOPMENT.

(a) The Secretary shall establish a research, development, demonstration, and commercial application program on metallurgical coal utilization for the purpose of developing techniques that will lead to the greater and more efficient utilization of the Nation's metallurgical coal resources.

(b) The program referred to in subsection (a) shall include the use of metallurgical coal-

(1) as a boiler fuel for the purpose of generating steam to produce electricity, including blending metallurgical coal with other coals in order to enhance its efficient application as a boiler fuel;

(2) as an ingredient in the manufacturing of steel; and

(3) as a source of pipeline quality coalbed methane.

SEC. 1308. UTILIZATION OF COAL WASTES.

(a) COAL Waste Utirization Program.-The Secretory, in consultation with the Secretary of the Interior, shall establish a research, development, demonstration, and commercial application program on coal waste utilization for the purpose of developing technigues that will lead to the greater and more efficient utilization of coal wastes from mining and processing, other than coal ash.

(b) USE AS BOILER FUEL. - The program referred to in subsection (a) shall include projects to facilitate the use of coal wastes $1.0 \mathrm{~m}$ mining and processing as a boiler fuel for the purpose of generating steam to produce electricity. 
210

SEC. 1309. LNDERGROUND COAL GASIFICATION.

(a) Program. - The Secretary shall conduct a research, development, demonstration, and commercial application program for underground coal gasification technology for in-situ conversion of coal to a cleaner burning, easily transportable gaseous fuel. The goal and objective of this program shall be to accelerate the development and commercialization of underground coal gasification. In carrying out this program, the Secretary shall give equal consideration to all ranks of coal.

(b) DEMONSTRATION PROSECTS.-As part of the program author. ized in subsection (a), the Secretary may solicit proposals for under. ground coal gasification technology projects to fulfill the goal and objective of subsection (a).

SEC. 1310. LOW.RANK COAL RESEARCH AND DEVELOPMENT.

The Secretary shall pursue a program of research and develop. ment with respect to the technologies needed to expand the use of low-rank coals which take into account the unique properties or lignites and sub-bituminous coals, including, but not limited to, the following areas-

(1) high value-added carbon products;

(2) fuel cell applications;

(3) emissions control and combiustion efficiencies;

(4) coal water fuels and underground coal gasification;

(5) distillates; and

(6) any other technologies which will assist in the develop-

ment of niche markets for lignites and sub-bituminous coals.

SEC. 1311. MAGNETOHYDRODYNAHICS.

(a) PROGRam. - The Secretary shall carry out a research, development, demonstration, and commercial application program in magnetohydrodynamics. The purpose of this program shall be to determine the adequacy of the engineering and design information completed to date under Department of Energy contracts related to magnetohydrodynamics retrofit systems and to determine whether any further Federal investment in this technology is warranted.

(b) Solicitation of Proposals.-In order to carry out the program authorized in subsection (a), the Secretary may solicit proposals from the private sector and seek to enter into an agreement with appropriate parties.

SEC. 1312. OIL SUBSTITUTION THROUGH COAL LIQUEFACTION.

(a) Program Direction.-The Secretary shall conduct a program of research, development, demonstration, and commercial application for the purpose of developing economically and environmentally acceptable advanced technologies for oil substitution through coal liquefaction.

(b) PROGRAM GOALS. -The goals of the program established under subsection (a) shall include-

(1) improved resource selection and product quality;

(2) the development of technologies to increase net yield of liquid fuel product per ton of coal;

(3) an increase in overall thernal efficiency; and

(4) a reduction in capital and operating costs through technology improvements. 
(c) Proposazs. - Within 180 days after the date of enactment of . this Act, the Secretary shall solicit proposals for conducting activi. ties under this section.

SEC. 1313. AUTHORIZATION OF APPROPRIATIONS.

There are authorized to be appropriated to the Secretary for car. rying out this subtitle \$278,139,000 for fiscal year 1993 and such sums as may be necessary for fiscal years 1994 through 1997.

\section{Subtitle B-Clean Coal Technology Program}

\section{SEC. 1321. ADDITIONAL CLEAN COAL TECHNOLOGY SOLICITATIONS.}

(a) Program Design.-Additional clean coal technology solicitations described in subsection (b) shall be designed to ensure the timely development of cost-effective technologies or energy production processes or systems utilizing coal that achieve greater efficien. cy in the conversion of coal to useful energy when compared to cur. rently commercially available technology for the use of coal and the control of emissions from the combustion of coal. Such program shall be designed to ensure, to the greatest extent passible, the availability for commercial use of such technologies by the year 2010.

(b) ADDITIONAL Solicitations. - In conducting the Clean Coal Program established by Public Law 98-473, the Secretary shall consider the potential benefits of conducting additional solicitations pursuant to such program and, based on the results of that consideration, may carry out such additional solicitations, which shall be similar in scope and percentage of Federal cost sharing as that provided by Public Law 101-121.

\section{Subtitle C-Other Coal Provisions}

SEC. 1331. CLEAN COAL TECHNOLOGY EXPORT PROMOTION AND INTER. AGENCY COORDINATION.

(a) ESTABLISHMENT.-There shall be established within the Trade Promotion Coordinating Committee lestablished by the President on May 23, 1990, a Clean Coal Technology Subgroup (in this subtitle referred to as the "CCT Subgroup") to focus interagency efforts on clean coal technologies. The CCT Subgroup shall seek to expand the export and use of clean coal technologies, particularly in those countries which can benefit from gains in the efficiency of, and the control of environmental emissions from coal utilization.

(b) MEMBERSHIP. - The CCT Subgroup shall include 1 member from each agency represented on the Energy, Environment, and Infrastructure Working Group of the Trade Promotion Coordinating Committee as of the date of enactment of this Act. The Secretary shall serve as chair of the CCT Subgroup and shall be responsible for ensuring that the functions of the CCT Subgroup are carried out through its member agencies.

(c) Consultation.-(1) In carrying out this section, the CCT Subgroup shall consult with representatives from the United States coal industry, representatives of railroads and other transportation industries, organizations representing workers, the electric utility industry, manufacturers of equipment utilizing clean coal technology, 
212

members of organizations formed to further the goals of environ. mental protection or to promote the development and use of clean coal technologies that are developed, manufactured, or controlled by United States firms, and other appropriate interested members of the public.

(2) The CCT Subgroup shall maintain ongoing liaison with other elements of the Trade Promotion Coordinating Committee re. lating to clean coal technologies or regions where these technologies could be important, including Eastern Europe. Asia, and the Pacific. shall-

(d) DUTIES. - The Secretary, acting through the CCT Subgroup,

(1) facilitate the establishment of technical training for the consideration, planning, construction, and operation of clean coal technologies by end users and international development personnel;

(2) facilitate the establishment of and. where practicable, cause to be established, consistent with the goals and objectives stated in section 1301(a), within existing departments and agencies-

(A) financial assistance programs (including grants, loan guarantees, and no interest and low interest loans) to support prefeasibility and feasibility studies for projects that will utilize clean coal technologies; and

(B) loan guarantee programs, grants, and no interest and low interest loans designed to facilitate access to capital and credit in order to finance such clean coal technolo. gy projects;

(3) develop and ensure the execution of programs, including the establishment of financial incentives, to encourage and support private sector efforts in exports of clean coal technologies that are developed, manufactured, or controlled by United States firms;

(4) encourage the training in, and understanding of, clean coal technologies by representatives of foreign companies or countries intending to use coal or clean coal technologies by providing technical or financial support for training programs, workshops, and other educational programs sponsored by United States firms;

(5) educate loan officers and other officers of international lending institutions, commercial and energy attaches of the United States, and such other personnel as the CCT Subgroup considers appropriate, for the purposes of providing information about clean coal technologies to foreign governments or potential project sponsors of clean coal technology projects;

(6) develop policies and pracilices to be conducted by com. mercial and energy attaches of the United States, and such other personnel as the CCT Subgroup considers appropriate, in order to promote the exports of clean coal technologies to those countries interested in or intending to utilize coal resources;

(7) augment budgets for trade and development programs supported by Federal agencies for the purpose of financially supporting prefeasibility or feasibility studies for projects in for. eign countries that will utilize clean coal technologies; 
(8) review ongoing clean coal technology projects and review and advise Federal agencies on the approval of planned clean coal technology projects which are sponsored abroad by any Federal agency to determine whether such projects are consistent with the overall goals and objectives of this section;

(9) coordinate the activities of the appropriate Federal agencies in order to ensure that Federal clean coal technology export promotion policies are implemented in a timely fashion;

(10) work with CCT Subgroup member agencies to develop an overall strategy for promoting clean coal technology exports, including setting goals and allocating specific responsibilities among member agencies, consistent with applicable statutes; and

(11) coordinate with multilateral institutions to ensure that United States technologies are properly represented in their projects.

(e) DATA AND I.NFORMATION.-(1) The CCT Subgroup, consistent with other applicable provisions of law, shall ensure the development of a comprehensive data base and information dissemination system, using the National Trade Data Bank and the Commercial Information Management System of the Department of Commerce. relating to the availability of clean coal technologies and the potential need for such technologies, particularly in developing countries and countries making the transition from nonmarket to market economies.

(2) The Secretary, acting through the CCT Subgroup, shall assess and prioritize foreign markets that have the most potential for the export of clean coal technologies that are developed, manufactured, or controlled by United States firms. Such assessment shall include-

(A) an analysis of the financing requirements for clean coal technology projects in foreign countries and whether such projects are dependent upon financial assistance from foreign countries or multilateral institutions;

(B) the availability of other fuel or energy resources that may be available to meet the energy requirements intended to be met by the clean coal technology projects;

(C) the priority of environmental considerations in the selection of such projects;

(D) the technical competence of those entities likely to be involved in the planning and operation of such projects;

(E) an objective comparison of the environmental, energy, and economic performance of each clean coal technology rela. tive to conventional technologies;

(F) a list of United States vendors of clean coal technologies; and

(G) answers to commonly asked questions about clean coal technologies,

The Secretary, acting through the-CCT Subgroup, shall make such information available to the House of Representatives and the Senate, and to the appropriate committees of each House of Congress, industry, Federal and international financing organizations. nongovernmental organizations, potential customers abroad, govern- 
ments of countries where such clean coal technologies might be used, and such others as the CCT Subgroup considers appropriate.

(f) REPORT. - Within 180 days afier the Secretary submits the report to the Congress as required by section 409 of Public Law 101549. the Secretary, acting through the CCT Subgroup, shall provide to the appropriate committees of the House of Representatives and the Committee on Energy and Natural Resources of the Senate, a plan which details actions to be taken in order to address those recommendations and findings made in the report submitted pursuant to section 409 of Public Law 101-549. As a part of the plan required by this subsection, the Secretary, acting through the CCT Subgroup, shall specifically address the adequacy of financial assistance avail. able from Federal departments and agencies and international financing organizations to aid in the financing of prefeasibility and feasibility studies and projects that would use a clean coal technology in developing countries and countries making the transition from nonmarket to market economies.

SEC. 1332. INNOVATIVE CLEAN COAL TECHNOLOGY TRA.VSFER PROGRA.H.

(a) ESTABLISHMENT OF PROGRAM.-The Secretary, through the Agency for International Development, and in consultation with the other members of the CCT Subgroup, shall establish a clean coal technology transfer program to carry out the purposes described in subsection (b). Within 150 days after the date of enactment of this Act, the Secretary and the Administrator of the Agency for International Development shall enter into a uritten agreement to carry out this section. The agreement shall establish a procedure for resolving any disputes between the Secretary and the Administrator regarding the implementation of specific projects. With respect to countries not assisted by the Agency for International Development, the Secretary may enter into agreements with other appropriate United States agencies. If the Secretary and the Administrator, or the Secretary and an agency described in the previous sentence, are unable to reach an agreement, each shall send a memorandum to the President outlining an appropriate agreement. Within 90 days after receipt of either memorandum, the President shall determine which version of the agreement shall be in effect. Any agreement entered into under this subsection shall be provided to the appropriate committees of the Congress and made available to the public.

(b) PURPOSES OF THE PROGRAM. - The purposes of the technology transfer program under this section are to-

(1) reduce the United States balance of trade deficit through the export of United States energy technologies and technological expertise;

(2) retoin and create manufacturing and related service jobs in the United States:

(3) encourage the export of United States technologies, including services related thereto, to those countries that have a need for developmentally sound facilities to provide energy derived from coal resources;

(4) develop markets for United States technologies and, where appropriate, United States coal resources to be utilized in meeting the energy and environmental requirements of foreign countries; 
(5) better ensure that United States participation in energyrelated projects in foreign countries includes participation by United States firms as well as utilization of United States technologies that have been developed or demonstrated in the United States through publicly or privately funded demonstration programs;

(6) provide for the accelerated deployment of United States technologies that will serve to introduce into foreign countries United States technologies intended to use coal resources in a more efficient, cost-effective, and environmentally acceptable manner;

(7) serve to ensure the introduction of United States firms and expertise in foreign countries;

(8) provide financial assistance by the Federal Government to foster greater participation by United States firms in the fi. nancing, ownership, design, construction, or operation of clean coal technology projects in foreign countries;

(9) assist foreign countries in meeting their energy needs through the use of coal in an environmentally acceptable manner, consistent with sustainable development policies; and

(10) assist United States firms, especially firms that are in competition with firms in foreign countries, to obtain opportunities to transfer technologies to, or undertake projects in, foreign countries.

(c) IDENTIFICATION.-Pursuant to the agreements required by subsection (a), the Secretary, through the Agency for International Development, and after consultation with the CCT Subgroup, - United States firms, and representatives from foreign countries, shall develop mechanisms to identify potential energy projects in host countries, and shall identify a list of such projects within 240 days after the date of enactment of this Act, and periodically there. after.

(d) Financtal Mechanisms. - (1) Pursuant to the agreements under subsection (a), the Secretary, through the Agency for International Development, shall-

(A) establish appropriate financial mechanisms to increase the participation of United States firms in energy projects utilizing United States clean coal technologies, and services related thereto, in developing countries and countries making the transition from nonmarket to market economies;

(B) utilize available financial assistance authorized by this section to counterbalance assistance provided by foreign governments to non-United States firms; and ing-

(C) provide financial assistance to support projects, includ-

(i) financing the incremental costs of a clean coal technology project attributable only to expenditures to prevent or abate emissions;

(ii) providing the difference between the costs of a conventional energy project in the host country and a compara. ble project that would utilize a clean coal technology capable of achieving greater efficiency of energy products and improved environmental emissions compared to such conventional project; and 
(iii) such other forms of financial assistance as the Sec. retary, through the Agency for International Development, considers appropriate.

(2) The financial assistance authorized by this section may be(A) provided in combination with other forms of financial assistance, including non-United States funding that is available to the project; and

$(B)$ utilized to assist United States firms to develop innova. tive financing packages for clean coal technology projects that seek to utilize other financial cussistance programs available through other Federal agencies.

(3) United States obligations under the Arrangement on Guidelines for Officially Supported Export Credits established through the Organization for Economic Cooperation and Development shall be applicable to this section.

(e) SOLICITATIONS fOR PROJECT Proposals. - (1) Pursuant to the agreements under subsection (a), the Secretary, through the Agency for International Development, within one year after the date of en. actment of this Act, and subsequently as appropriate thereafter, shall solicit propasals from United States firms for the design, con. struction, testing, and operation of the project or projects identified under subsection (c) which propose to utilize a United States technology. Each solicitation under this section shall establish a closing date for receipt of proposals.

(2) The solicitation under this subsection shall, to the extent ap. propriate, be modeled after the RFP No. DE-PS01-90FE62271 Clean Coal Technology IV as administered by the Department of Energy. (3) Any solicitation made under this subsection shall include the following requirements:

(A) The United States firm that submits a proposal in response to the solicitation shall have an equity interest in the proposed project.

(B) The project shall utilize a United States clean coal tech. nology, including services related thereto, and, where appropriate, United States coal resources, in meeting the applicable energy and environmental requirements of the host country.

(C) Proposals for projects shall be submitted by and under. taken with a United States firm, although a joint venture or other teaming arrangement with a non-United States manufacturer or siher non-United States entity is permissible.

(f) Assistance to UNITED STATES FIRMS.-Pursuant to the agreements under subsection (a), the Secretary, through the Agency for International Development, and in consultation with the CCT Subgroup, shall establish a procedure to provide financial assistance to United States firms under this section for a project identified under subsection (c) where solicitations for the project are being conducted by the host country or by a multilateral lending institution.

(g) Other Program Requiremzints.-Pursuant to the agreements under subsection (a), the Secretary, through the Agency for International Development, and in consultation with the CCT Subgroup, shall-

projects;

(1) establish eligibility criteria for countries that will host 
(2) periodically review the energy needs of such countries and export opportunities for United States firms for the development of projects in such countries;

(3) consult with government officials in host countries and, as appropriate, with representatives of utilities or other entities in host countries, to determine interest in and support for potential projects; and

(4) determine whether each project selected under this section is developmentally sound, as determined under the criteria developed by the Development Assistance Committee of the Organization for Economic Cooperation and Development.

(h) SELECTION of PROJECTS. - (1) Pursuant to the agreements under subsection (a), the Secretary, through the Agency for Interna. tional Development, shall, not later than 120 days after receipt of proposals in response to a solicitation under subsection (e), select one or more proposals under this section.

(2) In selecting a proposal under this section, the Secretary, through the Agency for International Development, shall consider-

(A) the ability of the United States firm, in cooperation with the host country, to undertake and complete the project;

$(B)$ the degree to which the equipment to be included in the project is designed and manufactured in the United States;

(C) the long-term technical and competitive viability of the United States technology, and services related thereto, and the ability of the United States firm to compete in the development of additional energy projects using such technology in the host country and in other foreign countries;

(D) the extent of technical and financial involvement of the hast country in the project;

(E) the extent to which the proposed project meets the goals and objectives stated in section 1301(a);

(F) the extent of technical, financial, management, and marketing capabilities of the participants in the project, and the commitment of the participants to completion of a success. ful project in a manner that will facilitate acceptance of the United States technology for future application; and

(G) such other criteria as may be appropriate.

(3) In selecting among proposed projects, the Secretary shall seek to ensure that, relative to otherwise comparable projects in the host country, a selected project will meet 1 or more of the following criteria:

(A) It will reduce environmental emissions to an extent greater than required by applicable provisions of law.

(B) It will increase the overall efficiency of the utilization of coal, including energy conversion efficiency and, where applicable, production of products derived from coal.

(C) It will be a more cost-effective technological alternative, based on life cycle capital and operating casts per unit of energy produced and, where applicable, costs per unit of product produced.

Priority in selection shall be given to those projects which, in the judgment of the Secretary, best meet one or more of these criteria. 
218

(i) United States-Asta ENvironmental Partnership.-AC. tivities carried out under this section shall be coordinated with the United States-Asia Environmental Partnership.

(j) BUY AMERICA. - In carrying out this section, the Secretary, through the Agency for International Development, and pursuant to the agreements under subsection (a), shall ensure-

(1) the maximum percentage, but in no case less than 50 percent, of the cost of any equipment furnished in connection with a project authorized under this section shall be attributable to the manufactured United States components of such equipment; and

(2) the maximum participation of United States firms.

In determining whether the cost of United States components equals or exceeds 50 percent, the cost of asisembly of such United States components in the host country shall not be considered a part of the cost of such United States component.

(k) REPORTS TO CONGRESS. - The Secretary and the Administrator of the Agency for International Development shall report annu. ally to the Committee on Energy and Natural Resources of the Senate and the appropriate committess of the House of Representatives on the progress being made to introduce clean coal technologies into foreign countries.

(l) DEFINITION.-For purposes of this section, the term "host country" means a foreign country which is-

(1) the participant in or the site of the proposed clean coal technology project; and

(2) either-

(A) classified as a country eligible to participate in de. velopment assistance prograrns of the Agency for International Development pursuani to applicable law or regulation; or

(B) a developing country or country with an economy in transition from a nonmarket to a market economy.

(m) AUTHORIZATION FOR PROGRAM. - There are authorized to be appropriated to the Secretary to carry out the program required by this section, $\$ 100,000,000$ for each of the fiscal years 1993, 1994, $1995,1996,1997$, and 1998.

SEC. 1333. CONVENTIONAL COAL TECHNOLOGY TRANSFER

If the Secretary determines that the utilization of a clean coal technology is not practicable for a proposed project and that a United States conventional coal technology would constitute a sub. stantial improvement in efficiency, costs, and environmental per. formance relative to the technology being used in a developing country or country making the transition from nonmarket to market economies, with significant indigenous coal resources, such technology shall. for purposes of sections 1321 and 1322 , be considered a clean coal technology. In the case of combustion technologies, only the retrofit, repowering, or replacement of a conventional technology shall constitute a substantial improvement for purposes of this section. In carrying out this section, the Secretary shall give highest priority to promoting the most environmentally sound and energy efficient technologies. 
SEC. 13S1. STUDY OF UTILIZATION OF COAL COHBLSTION BYPRODUCTS.

(a) DEFINITION. - As used in this section, the term "coal combus. tion byproducts" means the residues from the combustion of coal including ash, slag, and flue gas desulfurization materials.

(b) STUDY AND REPORT TO CONGRESS. - (1) The Secretary shall conduct a detailed and comprehensive study on the institutional, legal, and regulatory barriers to increased utilization of coal combustion byproducts by potential governmental and commercial users. Such study shall identify and investigate barriers found to exist at the Federah State, or local level, which may have limited or may have the foreseeable effect of limiting the quantities of coal combus. tion byproducts that are utilized. In conducting this study, the Secretary shall consult with other departments and agencies of the Federal Government, appropriate State and local governments, and the private sector.

(2) Not later than one year after the date of enactment of this Act, the Secretary shall submit a report to the Congress containing the results of the study required by paragraph (1) and the Secretary's recommendations for action to be taken to increase the utili. zation of coal combustion byproducts. At a minimum, such report shall identify actions that would increase the utilization of coal combustion byproducts in-

(A) bridge and highway construction;

(B) stabilizing wastes;

(C) procurement by departments and agencies of the Federal

Government and State and local governments; and

(D) federally funded or federally subsidized orocurement by

the private sector.

SEC. 1335. CALCULATION OF AVOIDED COST.

Nothing in section 210 of the Public Utility Regulatory Policies Act of 1978 (Public Law 95-617) requires a State regulatory authority or nonregulated electric utility to treat a cost reasonably identified to be incurred or to have been incurred in the construction or operation of a facility or a project which has been selected by the Department of Energy and provided Federal funding pursuant to the Clean Coal Program authorized by Public Law $98-473$ as an in. cremental cost of alternative electric energy.

SEC. 1336. COAL FUEL HIXTURES.

Within one year following the date of enactment of this Act, the Secretary shall submit a report to the Committee on Energy and Commerce and the Committee on Science, Space, and Technology of the House of Representatives and the Committee on Energy and Natural Resources of the Senate on the status of technologies for combining coal with other materials, such as oil or water fuel mixtures. The report shall include-

(1) a technical and economic feasibility assessment of such technologies;

(2) projected developments in such technologies;

(3) an assessment of the market potential of such technologies, including the potential to displace imported crude oil and refined petroleum products;

(4) identification of barriers to commercialization of such technologies; and 

ization.

(5) recommendations for addressing barriers to commercial-

SEC. 1337. VATIONAL CLEARINGHOLSE.

(a) FEASIBILITY. -11) The Secretary shall assess the feasibility of establishing a national clearinghouse for the exchange and dissemination of technical information on technology relating to coal and coal-derived fuels.

(2) In essessing the feasibility, the Secretary shall consider whether such a clearinghouse would be appropriate for purposes of-

(A) collecting information and data on technology relating to coal, and coal-derived fuels, which can be utilized to improve environmental quality and increase energy independence;

$(B)$ disseminating to appropriate individuals, governmental departments, agencies, and instrumentalities. institutions of higher education, and other entities, information and data collected pursuant to this section;

(C) maintaining a library of technology publications and treatises relating to technology information and data collected pursuant to this section;

(D) organizing and conducting seminars for government officials, utilities, coal companies, and other entities or institutions relating to technology using coal and coal-derived fuels that will improve environmental quality and increase energy in. dependence;

(E) gathering information on research grants made for the purpose of improving or enhancing technology relating to the use of coal, and coal-derived fuels, which will improve environ. mental quality and increase energy independence;

(F) translating into English foreign research papers, articles, seminar proceedings, test results that affect, or could affect, clean coal use technology, and other documents;

(G) encouraging, during the testing of technologies. the use of coal from a variety of domestic sources, and collecting or developing, or both, complete listings of test results using. coals from all sources;

(H) establishing and maintaining an index or compilation of research projects relating to clean coal technology carried out throughout the world; and

(I) conducting economic modeling for feasibility of projects.

(b) AUTHORITY TO EstaBLISH CLEAiringhot'SE.-Based upon the assessment under subsection (a), the Secretary may establish a clear. inghouse.

SEC. 1338. COAL EXPORTS.

(a) Pzan. - Within 180 days after the date of enactment of this Act, the Secretary of Commerce, in cooperation with the Secretary and other appropriate Federal agencies, shall submit to the appro. priate committees of the House of Representatives and the Committee on Energy and Natural Resources of the Senate a plan for expanding exports of cool mined in the United States.

(b) PLan Contents. - The plan submitted under subsection (a) shall include- 


\section{TITLE XX-GENERAL PROVISIONS; REDUCTION OF OIL VULNERABILITY}

\section{Subtitle A-Oil and Gas Supply Enhancement}

SEC. 2013. .VATURAL GAS SUPPLY.

(a) PROGRAM DIRECTION. - The Secretary shall conduct a 5-year program, in accordance with section 3001 and 3002 of this Act, to increase the recoverable natural gas resource base including, but not limited to-

(1) more intensive recovery of natural gas from discovered conventional resources;

(2) the extraction of natural gas from tight gas sands and devonian shales or other unconventional sources;

(3) surface gasification of coal; and

(4) recovery of methane from biofuels including municipal solid waste.

(b) Proposals. - Within 1 year after the date of enactment of this Act, the Secretary shall solicit proposals for conducting activities under this section.

(c) Cofiring OF NATURaL Gas and COAL-

(1) PRoGram. - The Secretary shall establish and carry out a 5-year program, in accordance with sections 3001 and 3002 of this Act, on cofiring natural gas with coal in utility and large industrial boilers in order to determine optimal natural gas injection levels for both environmental and operational benefits.

(2) FINANCIAL asSISTANCE. - The Secretary shall enter into agreements with, and provide financial assistance to, appropriate parties for application of cofiring technologies to boilers to demonstrate this technology.

(3) REPORT TO CONGRESS.-The Secretary shall, before December 31, 1995, submit to the Congress a report on the progress made in carrying out this subsection.

(d) AUTHORIZATION OF APPROPRIATIONS.-There are authorized to be appropriated to the Secretary for carrying out this section and sections 2014 and 2015, \$29,745,000 for fiscal year 1993 and $\$ 45,000,000$ for fiscal year 1994 . 
Appendix C

DOE Budget Data 
DOE Fossil Energy Coal R\&D Budget, FY 1976 through FY 1994

\begin{tabular}{|c|c|c|c|c|}
\hline Activity & FY 1976 & FY 1977 & FY 1978 & FY 1979 \\
\hline Coal & 310,598 & & & \\
\hline Coal Liquefaction & & 103,000 & 107,400 & 197,426 \\
\hline Surface Coal Gasification & & 94,506 & 193,900 & 164,598 \\
\hline Advanced Power Systems & & 22,500 & 25,700 & 26,900 \\
\hline Direct Combustion & & 51,916 & 60,400 & 51,701 \\
\hline Advanced Research and Technology Development & & 44,135 & 49,900 & 64,551 \\
\hline Demonstration Plants & & 53,000 & 44,900 & \\
\hline Magnetohydrodynamics & & 40,000 & 70,500 & 80,000 \\
\hline In Situ Gasification & & 8,236 & 12,600 & \\
\hline Mining R\&D & & & & 75,836 \\
\hline Advanced Environmental Control Technologies & & & & 7,000 \\
\hline TOTAL & $\$ 310,598$ & $\$ 417,293$ & $\$ 565,300$ & $\$ 668,012$ \\
\hline
\end{tabular}




\begin{tabular}{lrrrrr}
\hline Activity & FY 1980 & FY 1981 & FY 1982 & FY 1983 & FY 1984 \\
\hline Control Technologies and Coal Preparation & 38,250 & 37,500 & 21,984 & $27,900^{\mathrm{a}}$ & 26,000 \\
Advanced Research and Technology & 56,150 & 58,261 & 56,256 & 35,950 & 45,790 \\
Development & & & & & \\
Coal Liquefaction & 250,306 & 521,400 & 98,784 & 37,600 & 28,900 \\
Combustion Systems & 50,850 & 56,500 & 30,544 & 24,200 & 18,200 \\
Fuel Cells & 26,500 & 32,000 & 34,464 & 30,050 & 42,600 \\
Heat Engines & 50,500 & 36,400 & 15,408 & 5,000 & 6,500 \\
Underground Coal Gasification & 10,000 & 10,000 & 8,256 & 6,000 & 6,000 \\
Magnetohydrodynamics & 75,000 & 67,000 & 21,840 & 29,000 & 30,000 \\
Mining R\&D & 68,850 & 49,500 & 14,160 & & \\
Surface Coal Gasification & 115,850 & 164,900 & 53,088 & 39,000 & 35,790 \\
TOTAL & $\$ 742,256$ & $\$ 1,033,461$ & $\$ 354,784$ & $\$ 234,700$ & $\$ 239,780$ \\
\hline
\end{tabular}

${ }^{\text {a}}$ In FY 1983, coal preparation was transferred from the Mining R\&D activity to a new activity, Control Technologies and Coal Preparation, which also incorporated the earlier Advanced Environment Control Technologies activity. The new Mining R\&D activity was transferred to the U.S. Bureau of Mines. 


\begin{tabular}{lrrrrr}
\hline Activity & FY 1985 & FY 1986 & FY 1987 & FY 1988 & FY 1989 \\
\hline Control Technologies and Coal Preparation & 35,083 & 33,256 & 37,826 & 41,578 & 48,927 \\
Advanced Research and Technology & 40,011 & 35,233 & 32,387 & 31,877 & $25,56 \dot{4}$ \\
Development & & & & & \\
Coal Liquefaction & 25,815 & 32,912 & 24,107 & 27,129 & 32,389 \\
Combustion Systems & 30,218 & 30,302 & 15,142 & 21,816 & 26,696 \\
Fuel Cells & 40,811 & 35,449 & 28,084 & 32,653 & 26,534 \\
Heat Engines & 11,948 & 12,817 & 12,146 & 17,945 & 22,832 \\
Underground Coal Gasification & 5,753 & 4,238 & 2,370 & 2,777 & 1,371 \\
Magnetohydrodynamics & 30,977 & 28,850 & 26,500 & 35,000 & 37,000 \\
Surface Coal Gasification & 32,011 & 43,011 & 24,655 & 22,993 & 21,557 \\
TOTAL & $\$ 252,627$ & $\$ 256,068$ & $\$ 203,217$ & $\$ 233,768$ & $\$ 242,870$ \\
\hline
\end{tabular}




\begin{tabular}{lrrrrr}
\hline Activity & FY 1990 & FY 1991 & FY 1992 & FY 1993 & FY 1994 \\
\hline Control Technology and Coal Preparation & 58,376 & 55,724 & 51,063 & 42,574 & 46,081 \\
Advanced Research and Technology Development & 26,738 & 31,376 & 30,227 & 26,520 & 29,021 \\
Coal Liquefaction & 34,982 & 42,677 & 39,463 & 37,357 & 34,204 \\
Combustion Systems & 33,615 & 36,909 & 37,680 & 36,676 & 46,434 \\
Fuel Cells & 38,501 & 42,890 & 51,305 & 51,128 & $b$ \\
Heat Engines & 21,219 & 23,615 & 18,184 & 4,330 & \\
Underground Coal Gasification & 826 & 790 & & & \\
Magnetohydrodynamics & 40,900 & 40,039 & 40,286 & 30,325 & 4,822 \\
Surface Coal Gasification & 23,737 & 15,046 & 11,109 & 10,871 & 15,700 \\
TOTAL & $\$ 278,894$ & $\$ 289,066$ & $\$ 279,317$ & $\$ 239,781$ & $\$ 176,262$ \\
\hline
\end{tabular}

'In FY 1994 the fuel cells activity was transferred to the natural gas program. Source: DOE budget archives. 


\section{Appendix D \\ Environmental Issues Affecting Coal Use}

Future coal use in the United States will be strongly influenced by environmental concerns. In this appendix, recent trends in U.S. regulatory policy and technology development to address environmental issues are reviewed.

\section{Air Quality Standards}

National ambient air quality standards for particulate matter, sulfur dioxide $\left(\mathrm{SO}_{2}\right)$, nitrogen dioxide $\left(\mathrm{NO}_{2}\right)$, and photochemical ozone were promulgated under the 1970 Clean Air Act to protect human health and welfare throughout the country. In some regions of the country, additional air quality standards for the "prevention of significant deterioration" of superior air quality also apply. To achieve air quality standards and to speed the deployment of loweremission technologies, emission standards for new and existing air pollution sources have been promulgated by federal and state governments over the past two decades. These pollutantspecific emission standards, together with environmental quality standards, have been the primary forces of technology innovation for environmental control. Recent developments in air quality and emission standards for coal-based systems are discussed below.

\section{Sulfur Dioxide}

Ambient air quality standards for $\mathrm{SO}_{2}$, together with federal New Source Performance Standards (NSPS) promulgated in 1971 and 1979, have brought about a profound change in the design of modern coal-fired power plants. Today, $\mathrm{SO}_{2}$ control systems are a necessary component of new coal-based power generation. While air quality standards for $\mathrm{SO}_{2}$ now have been achieved in most regions of the United States, state and local regulations for "best-available control technology," plus new federal regulations to control acid deposition, have given further impetus to $\mathrm{SO}_{2}$ controls.

The trend in $\mathrm{SO}_{2}$ emissions from a new coal-fired power plant is illustrated in Figure 3-2a for an eastern U.S. plant burning medium-sulfur coal similar to the U.S. average. The original NSPS limited emissions to $1.2 \mathrm{lb} \mathrm{SO}_{2} / 10^{6} \mathrm{Btu}$. For the illustrative plant in Figure $3-2$, that corresponded to an emissions reduction of about 75 percent relative to a pre-NSPS plant with no $\mathrm{SO}_{2}$ controls. That reduction could be achieved either by switching to a low-sulfur coal or 
by installing a flue gas desulfurization (FGD) system. Revisions to the NSPS effective in 1979 eliminated the option of compliance through coal switching, requiring instead that all plants continuously reduce $\mathrm{SO}_{2}$ emissions by 70 to 90 percent, depending on the coal burned. For eastern plants burning medium- to high-sulfur coal, this effectively halved the original NSPS emissions to $0.6 \mathrm{lb} \mathrm{SO}_{2}$ /million Btu. Western plants burning low-sulfur coal emitted much less. These reductions were achieved using a variety of FGD systems, which are now found on approximately 25 percent (70 GW) of U.S. coal-fired capacity (DOE, 1993). Over the past decade, the efficiency of FGD systems has continued to improve.

An important implication of the trend in $\mathrm{SO}_{2}$ removal capability for conventional coalfired power plants is the downward pressure on achieving similar levels of emission reductions for advanced coal conversion systems. Fluidized-bed combustion systems, for example, originally were designed to meet the 90 percent $\mathrm{SO}_{2}$ removal requirements of the NSPS but have not yet demonstrated the ability to economically meet the 98 percent or higher reductions now achieved in the United States with commercially available FGD systems. Though such levels of $\mathrm{SO}_{2}$ reduction are not yet required of all new coal-based power generation, continuing pressure from state and local regulators and the possibility of further tightening of the NSPS within the next decade point to the need for sustained efforts to achieve very high levels of $\mathrm{SO}_{2}$ control for advanced coal conversion technologies.

\section{Particulate Matter}

In 1987 the original ambient air quality standards for total suspended particulates were augmented by a standard based on fine (respirable) particulates less than 10 microns in size. The EPA (U.S. Environmental Protection Agency) has indicated that another revision to the healthbased fine particulate standard, possibly an air quality standard for fine particles of 2 to 3 microns, is likely before the end of the decade (Bachman, 1994). The implication of that change could be a further tightening of particulate emissions from coal combustion sources in the nearto mid-term period. Restrictions on fine particulates also could require control of gaseous sulfates and nitrates, which condense in the atmosphere to form micron-sized particles.

The federal NSPS for particulate emissions from coal-fired power plants has been tightened by a factor of three since standards were first promulgated in 1971 (see Figure 3-2b). Modern electrostatic precipitators and fabric filters routinely achieve emission levels significantly below the federal standard, with commercial designs today achieving one-third the NSPS level (Sloat et al., 1993). Some baghouses now in use achieve particulate emission levels of 0.005 $\mathrm{lb} /$ million Btu, or one-sixth the NSPS requirement (EPRI, 1992). With the likelihood of a new air quality standard for fine particles, the potential exists for future emission limits based on particle size as well as total mass.

\section{Nitrogen Dioxide}

The health-based ambient air quality standard for $\mathrm{NO}_{2}$ has not been a major forcing function for power plant control technology development. However, the federal NSPS for 
nitrogen oxides $\left(\mathrm{NO}_{\mathrm{x}}\right.$, a mix of $\mathrm{NO}$ and $\mathrm{NO}_{2}$ ) has brought about a number of changes in the design of new coal-fired boilers. The 1971 NSPS of $0.7 \mathrm{lb} \mathrm{NO}$ /million Btu led to the extinction of new cyclone-fired boilers, which have high $\mathrm{NO}_{\mathrm{x}}$ emissions, and stimulated a variety of low$\mathrm{NO}_{\mathrm{x}}$ burner designs. In 1979 the NSPS was tightened slightly, reflecting improvements in combustion-based controls (see Figure 3-2c). The overall level of $\mathrm{NO}_{\mathrm{x}}$ reduction now being achieved at new coal-fired plants is roughly 50 percent of uncontrolled pre-NSPS levels. As noted earlier, the environmental issues of acid deposition, fine particles, and urban ozone are likely to push requirements for greater $\mathrm{NO}_{\mathrm{x}}$ controls in the near future.

\section{Ozone}

Attainment of the health-related national air quality standard for tropospheric ozone, the major constituent of photochemical smog, poses some of the most difficult environmental challenges in the United States. Though this problem traditionally has been associated with Los Angeles and the automobile, evidence shows the problem to be far more widespread, with many metropolitan areas throughout the country exceeding the national standard (EPA, 1990). Photochemical ozone is formed from emissions of volatile organic compounds and $\mathrm{NO}_{\mathrm{x}}$ via a complex series of chemical reactions fueled by sunlight. To date, reductions in ozone have been sought primarily by reducing emissions of volatile organic compounds. Improved understanding of photochemical smog formation, however, now indicates that $\mathrm{NO}_{\mathrm{x}}$ controls must be a more significant component of ozone reduction strategies (NRC, 1991).

Federal standards for new automobiles already have reduced mobile source $\mathrm{NO}_{x}$ emissions significantly in the past two decades. As a result, power plants today account for about half the total U.S. $\mathrm{NO}_{x}$ emissions. After the further reductions in automotive and power plant $\mathrm{NO}_{x}$ mandated by the 1990 CAAAs (Clean Air Act amendments), $\mathrm{NO}_{x}$ emissions from power plants will be twice as great as automobiles and the largest source of $\mathrm{NO}_{\mathrm{x}}$ emissions nationally around the turn of the century (Bachman, 1994). Therefore, it can be expected that ozone reduction strategies in the Northeast and other parts of the United States will focus increasingly on $\mathrm{NO}_{x}$ emissions from new and existing fossil-fueled power plants. A tightening of the ambient ozone standard also is under consideration by EPA based on recent health studies (Bachman, 1994). Though the timing and magnitude of $\mathrm{NO}_{x}$ reduction requirements to achieve ambient ozone standards is highly uncertain, the implication of current trends in regulation and technology development is that stringent $\mathrm{NO}_{x}$ controls of coal-based technologies could well emerge within the next decade.

\section{Acid Deposition}

The acid deposition provisions of the 1990 CAAAs established for the first time an absolute cap on total U.S. $\mathrm{SO}_{2}$ emissions. In contrast to ambient air quality standards, which primarily protect human health, acid deposition regulations primarily guard against a host of cultural and ecological concerns, including damage to aquatic systems, forests, visibility, and materials. The regional nature of acid deposition and the role of long-range transport of 
pollutants require reductions in $\mathrm{SO}_{2}$ and $\mathrm{NO}_{\mathrm{x}}$ emissions over a broad geographical area, primarily the eastern half of the United States. The $\mathrm{SO}_{2}$ cap of 10 million tons per year established by the 1990 amendments will require a reduction of roughly 40 percent in current $\mathrm{SO}_{2}$ emissions from electric power plants, to be phased in by the turn of the century. A smaller reduction of 2 million tons per year in $\mathrm{NO}_{\mathrm{x}}$ emissions, about 10 percent of 1980 levels, also is mandated for acid deposition control. There is no cap on total $\mathrm{NO}_{\mathrm{x}}$ emissions, however.

The anticipation of acid rain controls was the prime factor motivating $\mathrm{SO}_{2}$ and $\mathrm{NO}_{x}$ control technology development during the 1980s. The longer-term implications of acid rain regulations for coal technology development are somewhat speculative. The absolute cap on $\mathrm{SO}_{2}$ emissions could provide incentives to seek high levels of $\mathrm{SO}_{2}$ control in order to accommodate long-term growth. Some scenarios, however, suggest that future $\mathrm{SO}_{2}$ emissions will continue to decline using power generation technologies that are currently available or will become available commercially in the near-term period, especially integrated gasification combined-cycle systems (NAPAP, 1991). Other factors also could affect future developments. For example, a new air quality standard for fine particulates, discussed earlier, could require additional $\mathrm{SO}_{2}$ controls to reduce particulate sulfate emissions.

\section{Air Toxics}

Title III of the 1990 CAAAs lists 189 substances as "air toxics" subject to "maximumachievable control technology" when emitted at rates of 10 to 25 tons per year from designated industrial and other sources. The air toxic provisions represented a major expansion in the number of air pollutant species of regulatory concern. Emissions from fossil-fueled power plants, however, were exempted from the provision of the amendments, pending further study by EPA. Extensive efforts currently are under way to characterize trace species emissions from coal-fired power plants as a basis for federal decisionmaking expected in late 1995 or soon thereafter. Air toxics concerns for utilities center primarily around 10 to 20 trace substances commonly found in coal, including arsenic, mercury, selenium, nickel, cadmium, and other heavy metals. The basis for regulating these species under the air toxics provisions would be a finding by EPA of an unacceptable health risk or an ecological risk to one or more regions of the country named in the 1990 CAAAs (Zeugin, 1992).

Individual states, however, could regulate on other grounds. Some states such as Wisconsin already are considering trace emission limitations for coal-burning plants based on trace substance concentrations in coal. ${ }^{1}$ The Electric Power Research Institute has compiled an extensive database of published information on trace substances, including extensive characterizations of U.S. coals. The data for bituminous, subbituminous, and lignite coals show large variability, often an order of magnitude or more, in trace species concentrations (Rubin et al., 1993). Detailed trace species data at the mine and seam levels, however, are not generally available, though a number of U.S. coal companies do possess proprietary information of that

\footnotetext{
${ }^{1}$ Personal communication from B.T. O’Neil, Electric Power Research Institute, to E.S. Rubin, Vice Chair, Committee on the Strategic Assessment of DOE's Coal Program, February 1994.
} 
type. EPRI and DOE currently are conducting extensive testing programs to characterize trace species emissions from conventional and advanced power plants.

\section{Global Warming}

Of all the environmental issues facing the future use of coal, none is as potentially far reaching as the worldwide concern over global climate change. For coal, emissions of carbon dioxide $\left(\mathrm{CO}_{2}\right)$ from combustion and methane from coal mining are the two greenhouse gases of primary concern. While it is likely to be at least a decade or more before the magnitude and consequences of global warming can be measured or predicted with reasonable scientific certainty, international concern over the potential effects of global warming has prompted recommendations and policy measures to curtail the growth in greenhouse gas emissions, primarily $\mathrm{CO}_{2}$ (e.g., NRC, 1992). As a result of the 1992 United Nations Conference on the Environment, the United States is signatory to an international accord to limit $\mathrm{CO}_{2}$ emissions to 1990 levels by the turn of the century. Recently, the Clinton administration put forth a program of largely voluntary measures to achieve that objective (Clinton and Gore, 1993).

Since coal combustion emits 20 to 75 percent more $\mathrm{CO}_{2}$ per unit of energy than other fossil fuels, it has been a major focus of attention and a key target for greenhouse gas reductions. Coal presently accounts for about 35 percent of total $\mathrm{CO}_{2}$ emissions globally. Emissions are projected to increase significantly in the next century, especially in developing countries such as China. Based on current estimates of natural resources, coal is the only fossil fuel with carbon reserves sufficient to dramatically increase the current carbon content of the atmosphere if burned on a widespread scale (Edmonds, 1994). Thus, there is substantial interest in the long-term trend in $\mathrm{CO}_{2}$ emissions from coal combustion and other conversion processes. Various studies have examined the potential to reduce coal-related greenhouse gas emissions (e.g., NRC, 1992).

\section{Water Quality Standards}

Coal-fired electric power plants and fuel conversion processes are subject to state and federal regulations to protect the quality of surface waters, ground water, and drinking water. Stream quality standards for specific receiving waters are established by state and local jurisdictions, while the NSPS are the primary federal vehicle limiting aqueous discharges. The principal environmental concerns are thermal discharges to waterways (which are prohibited for new plants) and various chemical emissions, including heavy metals, organics, suspended solids, and other aqueous constituents found in power plant waste streams. In recent years there has been increasing attention to a large number of hazardous or toxic trace chemical species and a general tightening of effluent emission standards at existing as well as new facilities (Rubin, 1989).

Reauthorization of the Clean Water Act is expected soon, with the potential for more stringent effluent standards for coal-based electric power plants. While water-related environmental controls have not had the visibility or economic impact of air pollution controls, 
future restrictions could nonetheless have significant consequences for power plant siting and cost. Some advanced power generation and fuel conversion technologies, which produce a variety of aqueous discharges not found in conventional pulverized coal plants, may merit special scrutiny. Overall, the research and development (R\&D) implication of current trends is that water-related environmental issues also may require additional attention to preserve or increase options and lower the cost of complying with current and future restrictions.

Water quality issues also affect other parts of the coal fuel cycle, especially coal mining and beneficiation. Acid mine drainage from coal extraction and effluents from coal preparation plants have historically been among the most serious water-related environmental problems associated with coal use. Research needs on advanced treatment technologies and improved process design to minimize or eliminate water-borne pollutants thus extend across the fuel cycle.

\section{Solid and Hazardous Wastes}

High-volume solid wastes from electric power plants, including fly ash, bottom ash, and FGD sludge, have been classified as nonhazardous under the Resource Conservation and Recovery Act of 1976. Thus, coal-fired power plants are largely exempt from the rigorous treatment requirements and high costs of dealing with hazardous wastes, although some lowvolume wastes such as boiler cleaning sludges may still fall under the "hazardous" category. Methods for cleaning coal and for meeting stringent air emission regulations often transform gaseous emissions to solid waste products. These waste products must then be used or disposed of in compliance with other regulatory standards that protect land, surface water, and ground water resources.

Nonetheless, the sheer volume of power plant wastes, and their potential to affect ground water and surface water quality, poses a continuing problem that can affect the viability of increased coal use in the future. From a cost viewpoint alone, waste disposal represents an increasing burden, especially for utilities in densely populated areas where land suitable for waste disposal is fast disappearing. This problem will continue to grow as land availability decreases in the next century. These issues also apply across the coal fuel cycle, including the mining and beneficiation stages where significant solid waste generation occurs.

Related to the issue of solid waste disposal are environmental requirements for land reclamation and control of mine subsidence. The latter issue is specifically cited for attention in the 1992 Energy Policy Act. R\&D needed to address these issues is likely to be shared between DOE and other federal agencies, such as the U.S. Bureau of Mines.

\section{Externalities and Siting Issues}

To an increasing extent, state and local governments, rather than the federal government, are forcing the most stringent environmental requirements for energy facilities, typically in conjunction with plant siting and operating permits. Thus, federal NSPS levels for power plants no longer set the benchmark for environmental control performance. Rather, state and local determinations of "lowest-achievable emission rates" have become the de facto requirements in 
many cases. Similarly, the most stringent requirements for treatment of solid and aqueous wastes often arise from state and local jurisdictions. The implication of this trend is that local and regional concerns will play an increasingly important role in establishing requirements for environmental control technology $R \& D$.

A related trend is the adoption by some state public utility commissions of "externality adders" to account for the environmental impacts of power plant emissions that escape control. Externality adders are economic costs added to the nominal cost of power generation, typically for the purpose of comparing different options. In some cases such adders are part of a larger program of "integrated resource planning" approaches used by state regulatory commissions to assess the relative merits and cost of proposed capacity additions by electric utility companies. More than half the states in the country are currently examining the use of externality adders as part of the regulatory decisionmaking process. Several states, including Washington, New York, and Massachusetts, have already adopted or anticipate adoption of externality adders (CECA, 1993). The effect of externality cost adders is to make coal-based power generation less attractive relative to other options having lower air pollutant and solid waste emissions. For coal to be viable, therefore, emissions reductions well below current regulätory requirements may be needed.

A final issue deserving mention is the concern over possible health effects of 60 -cycle $(\mathrm{Hz})$ electromagnetic fields. For some years now, there have been suggestions in the scientific and epidemiological literature of a link between the electric and magnetic fields induced by power transmission lines, distribution lines, and electric appliances and an increased risk of certain cancers, particularly childhood leukemia. To date, however, there has been no definitive evidence that such a link exists, nor have fundamental mechanisms been identified by which electromagnetic fields could induce biological effects (CIRRCP, 1992)..Nonetheless, public concern has caused public utility commissions in some states to prevent the siting of new transmission and distribution lines near populated areas. As with many complex environmental issues, it will likely be several decades before new scientific evidence can unambiguously shed light on this issue. In the meantime, the principle of "prudent avoidance" has been adopted by many state regulatory agencies and utilities, with the objective of avoiding exposure to $60-\mathrm{Hz}$ fields where options are readily available (Morgan, 1992). The implication of all this for the coal $R \& D$ program is to suggest that large central station facilities requiring extensive new transmission and distribution lines to deliver power become more difficult to deploy because of electromagnetic field concerns, thus favoring smaller more distributed systems.

\section{References}

Bachman, J. 1994. Presentation by John Bachman, U.S. Environmental Protection Agency, to the Committee on the Strategic Assessment of Department of Energy's Coal Program, National Academy of Sciences, Washington, D.C., January 27.

CECA. 1993. Incorporating Environmental Externalities into Utility Planning: Seeking a CostEffective Means of Assuring Environmental Quality. Washington, D.C.: Consumer Energy Council of America. 
CIRRPC. 1992. Health Effects of Low-Frequency Electric and Magnetic Fields, Report No. ORAU 92/F8. Committee on Interagency Radiation Research and Policy Coordination, Oak Ridge Associated Universities. Knoxville, Tennessee: ORAU.

Clinton, W.J., and A. Gore, Jr. 1993. The Climate Change Action Plan. Washington, D.C.: The White House.

DOE. 1993. Electric Power Annual 1991. Energy Information Administration, U.S. Department of Energy, DOE/EIA-0348(91). Washington, D.C.: DOE.

Edmonds, J. 1994. Presentation by J.A. Edmonds, Battelle Pacific Northwest Laboratories to the Committee on the Strategic Assessment of DOE's Coal Program, National Academy of Sciences, Washington, D.C., January 27.

EPA. 1990. Meeting the Environmental Challenge: EPA's Review of Progress and New Directions in Environmental Protection. U.S. Environmental Protection Agency, report no. 21K-29001. Washington, D.C.: EPA

EPRI. 1992. Report no. CS 5161. Palo Alto, California: Electric Power Research Institute.

Morgan, M.G. 1992. Prudent avoidance. Public Utilities Fortnightly. 129(6): 26-29.

NAPAP. 1991. The National Acid Precipitation Assessment Program: 1990 Integrated Assessment Report. Washington, D.C.: NAPAP.

NRC. 1991. Rethinking the Ozone Problem in Urban and Regional Air Pollution. Boards on Environmental Studies and Toxicology, and Armospheric Sciences and Climate, National Research Council. Washington, D.C.: National Academy Press.

NRC. 1992. Policy Implications of Greenhouse Warming. Committee on Science, Engineering, and Public Policy, National Research Council. Washington, D.C.: National Academy Press.

Rubin, E.S. 1989. The implications of future environmental regulations on coal-based electric power. Annual Review of Energy, Volume 14. Palo Alto, California: Annual Reviews.

Rubin, E.S., M.B. Berkenpas, H.C. Frey, and B.T. O'Neil. 1993. Modeling the uncertainty in hazardous air pollutant emissions. Paper presented at the Second International Conference on Managing Hazardous Air Pollutants, Electric Power Research Institute. Palo Alto, California, July. 
Sloat, D.G., R.P. Gaikwad, and R.L. Chang. 1993. The potential of pulse jet baghouses for utility boilers. Part 3: Comparative economics of pulse jet baghouses, precipitators and reverse-gas baghouses. Journal of the Air and Waste Management Association. 43 (January): 120-128.

Zeugin, L.E. 1992. Managing hazardous air pollutants: Implications of the 1990 Clean Air Act Amendments for coal combustion. Proceedings of Ninth Annual International Pittsburgh Coal Conference, October, Pittsburgh, Pennsylvania. Pittsburgh: University of Pittsburgh. 
Appendix E

\section{Clean Coal Technology Demonstration Projects}


Table E-1 CCT Program: LIST OF PROJECTS ADVANCED ELECTRIC POWER GENERATION SYSTEMS

\begin{tabular}{|c|c|c|c|c|c|}
\hline $\begin{array}{l}\text { PROJECT } \\
\text { Sponsor }\end{array}$ & Solicitation & $\begin{array}{l}\text { MW Scale of } \\
\text { Project }\end{array}$ & $\begin{array}{l}\text { DOE Obligation } \\
\text { (millions of } \\
\text { dollars) }\end{array}$ & $\begin{array}{l}\text { Private Obligation } \\
\text { (millions of dollars) }\end{array}$ & $\begin{array}{l}\text { Total Provisional } \\
\text { Cost Estimate } \\
\text { (millions of dollars) }\end{array}$ \\
\hline $\begin{array}{l}\text { COMBUSTION ENGINEERING IGCC } \\
\text { REPOWERING PROJECT } \\
\text { ABB Combustion Engineering, Inc. }\end{array}$ & CCT-II & 65 & $129.4(48 \%)$ & $141.3(52 \%)$ & 270.7 \\
\hline $\begin{array}{l}\text { HEALY CLEAN COAL PROJECT } \\
\text { Alaska Industrial Development and Export } \\
\text { Authority }\end{array}$ & CCT-III & 50 & $103.7(48 \%)$ & $111.3(52 \%)$ & 215.0 \\
\hline $\begin{array}{l}\text { PCFB DEMONSTRATION PROJECT } \\
\text { DMEC-1 Limited Partnership }\end{array}$ & CCT-III & 80 & $93.3(46 \%)$ & 109.7 (54\%) & 203.0 \\
\hline $\begin{array}{l}\text { TIDD PFBC DEMONSTRATION PROJECT } \\
\text { The Ohio Power Company }\end{array}$ & CCT-I & 70 & $60.2(31 \%)$ & $133.3(69 \%)$ & $\begin{array}{r}193.5+\text { cost } \\
\text { increase of } \$ 26.0 \mathrm{M}\end{array}$ \\
\hline $\begin{array}{l}\text { PINON PINE IGCC POWER PROJECT } \\
\text { Sierra Pacific Power Company }\end{array}$ & CCT-IV & 80 & $135.0(50 \%)$ & $135.0(50 \%)$ & 270.0 \\
\hline $\begin{array}{l}\text { TOMS CREEK IGCC DEMONSTRATION } \\
\text { PROJECT } \\
\text { TAMCO Power Partners }\end{array}$ & CCT-IV & 190 & $95.0(48 \%)$ & $101.6(52 \%)$ & 196.6 \\
\hline $\begin{array}{l}\text { TAMPA ELECTRIC INTEGRATED } \\
\text { GASIFICATION COMBINED-CYCLE PROJECT } \\
\text { Tampa Electric Company }\end{array}$ & CCT-III & 260 & $120.7(50 \%)$ & $120.7(50 \%)$ & 241.4 \\
\hline $\begin{array}{l}\text { NUCLA CFB DEMONSTRATION PROJECT } \\
\text { Tri-State Generation and Transmission } \\
\text { Association, Inc. }\end{array}$ & CCT-I & 110 & $19.9(37 \%)$ & $34.2(63 \%)$ & $54.1^{\text {b }}$ Completed \\
\hline $\begin{array}{l}\text { WABASH RIVER COAL GASIFICATION } \\
\text { REPOWERING PROJECT } \\
\text { Wabash River Coal Gasification Repowering } \\
\text { Project Joint Venture }\end{array}$ & CCT-IV & 268 & $198.0(50 \%)$ & $198.0(50 \%)$ & 396.0 \\
\hline $\begin{array}{l}\text { YORK COUNTY ENERGY PARTNERS } \\
\text { COGENERATION PROJECT } \\
\text { York County Energy Partners, L.P. }\end{array}$ & CCT-I & 227 & $74.7(20 \%)$ & $299.6(80 \%)$ & 374.3 \\
\hline $\begin{array}{l}\text { WARREN STATION EXTERNAL FIRED } \\
\text { COMBINED CYCLE } \\
\text { Penna Electric Company }\end{array}$ & CCT-V & 62 & $73.0(50 \%)$ & $73.0(50 \%)$ & 146.0 \\
\hline
\end{tabular}




\begin{tabular}{|c|c|c|c|c|c|}
\hline $\begin{array}{c}\text { PROJECT } \\
\text { Sponsor }\end{array}$ & Solicitation & $\begin{array}{l}\text { MW Scale of } \\
\text { Project }\end{array}$ & $\begin{array}{l}\text { DOE Obligation } \\
\text { (millions of } \\
\text { dollars) }\end{array}$ & $\begin{array}{l}\text { Private Obligation } \\
\text { (millions of dollars) }\end{array}$ & $\begin{array}{l}\text { Total Provisional } \\
\text { Cost Estimate } \\
\text { (millions of dollars) }\end{array}$ \\
\hline $\begin{array}{l}\text { CAMDEN IGCC (including fuel cell) } \\
\text { Duke Energy Corporation }\end{array}$ & CCT-V & 480 & $195.0(25 \%)$ & $585(75 \%)$ & 780.0 \\
\hline $\begin{array}{l}\text { CALVERT CITY, PCFB DEMONSTRATION } \\
\text { PROJECT } \\
\text { Air Products \& Chemical Company }\end{array}$ & CCT-V & 95 & $150.0(40 \%)$ & $225.0(60 \%)$ & 375.0 \\
\hline $\begin{array}{l}\text { SNOX FLUE GAS CLEANING } \\
\text { DEMONSTRATION PROJECT } \\
\text { ABB Combustion Engineering, Inc. }\end{array}$ & CCT-II & 35 & $15.7(50 \%)$ & $15.7(50 \%)$ & 31.4 \\
\hline $\begin{array}{l}\text { 10-MW DEMONSTRATION OF GAS } \\
\text { SUSPENSION ABSORPTION } \\
\text { AirPol, Inc. }\end{array}$ & CCT-III & 10 & $2.3(30 \%)$ & $5.4(70 \%)$ & 7.7 \\
\hline $\begin{array}{l}\text { DEMONSTRATION OF COAL REBURNING FOR } \\
\text { CYCLONE BOILER NO }{ }_{x} \text { CONTROL } \\
\text { Babcock \& Wilcox Company }\end{array}$ & CCT-II & 100 & $6.2(48 \%)$ & $6.9(52 \%)$ & 13.1 \\
\hline $\begin{array}{l}\text { FULL-SCALE DEMONSTRATION OF LOW-NO } \\
\text { CELL }^{\text {TM }} \text { BURNER RETROFIT } \\
\text { Babcock \& Wilcox Company }^{\text {a }}\end{array}$ & CCT-III & 605 & $5.4(48 \%)$ & $5.8(52 \%)$ & 11.2 \\
\hline $\begin{array}{l}\text { LIMB DEMONSTRATION PROJECT EXTENSION } \\
\text { AND COOLSIDE DEMONSTRATION } \\
\text { Babcock \& Wilcox Company }\end{array}$ & CCT-I & 105 & $7.6(39 \%)$ & $11.8(61 \%)$ & $19.4^{b}$ Completed \\
\hline $\begin{array}{l}\text { SOX-NOX-ROX BOX FLUE GAS CLEANUP } \\
\text { DEMONSTRATION PROJECT } \\
\text { Babcock \& Wilcox Company }\end{array}$ & CCT-II & $\begin{array}{l}5 \text { equivalent } \\
\text { slipstream from } \\
\text { a } 156 \text { boiler }\end{array}$ & $6.1(46 \%)$ & $7.2(54 \%)$ & 13.3 \\
\hline $\begin{array}{l}\text { CONFINED ZONE DISPERSION FLUE GAS } \\
\text { CLEANUP DEMONSTRATION } \\
\text { Bechtel Corporation }\end{array}$ & CCT-III & 73.5 & $5.2(50 \%)$ & $5.2(50 \%)$ & 10.4 \\
\hline $\begin{array}{l}\text { ENHANCING THE USE OF COALS BY GAS } \\
\text { REBURNING AND SORBENT INJECTION } \\
\text { Energy and Environmental Research Corporation }\end{array}$ & CCT-I & $\begin{array}{l}\text { 80-Hennepin } \\
\text { 40-Lakeside }\end{array}$ & $18.7(50 \%)$ & $18.7(50 \%)$ & 37.5 \\
\hline $\begin{array}{l}\text { EVALUATION OF GAS REBURNING AND } \\
\text { LOW-NO }{ }_{x} \text { BURNERS ON A WALL-FIRED } \\
\text { BOILER } \\
\text { Energy and Environmental Research Corporation }\end{array}$ & CCT-III & 172 & $8.1(50 \%)$ & $8.1(50 \%)$ & 16.2 \\
\hline
\end{tabular}




\begin{tabular}{|c|c|c|c|c|c|}
\hline $\begin{array}{c}\text { PROJECT } \\
\text { Sponsor } \\
\end{array}$ & Solicitation & $\begin{array}{l}\text { MW Scale of } \\
\text { Project }\end{array}$ & $\begin{array}{l}\text { DOE Obligation } \\
\text { (millions of } \\
\text { dollars) }\end{array}$ & $\begin{array}{l}\text { Private Obligation } \\
\text { (millions of dollars) }\end{array}$ & $\begin{array}{l}\text { Total Provisional } \\
\text { Cost Estimate } \\
\text { (millions of dollars) }\end{array}$ \\
\hline $\begin{array}{l}\text { LIFAC SORBENT INJECTION } \\
\text { DESULFURIZATION DEMONSTRATION } \\
\text { PROJECT } \\
\text { LIFAC-North America }\end{array}$ & CCT-III & 60 & $10.6(50 \%)$ & $10.8(50 \%)$ & 21.4 \\
\hline $\begin{array}{l}\text { COMMERCIAL DEMONSTRATION OF THE } \\
\text { NOXSO SO } \text { SNO }_{\times} \text {REMOVAL FLUE GAS } \\
\text { CLEANUP SYSTEM } \\
\text { MK-Ferguson Company }\end{array}$ & CCT-III & 115 & $33.1(50 \%)$ & $33.1(50 \%)$ & 66.3 \\
\hline $\begin{array}{l}\text { MILLIKEN CLEAN COAL TECHNOLOGY } \\
\text { DEMONSTRATION PROJECT } \\
\text { New York State Electric \& Gas Corporation }\end{array}$ & CCT-IV & 300 & $45(28 \%)$ & $113.6(72 \%)$ & 158.6 \\
\hline $\begin{array}{l}\text { NNTEGRATED DRY NO } \mathrm{NO}_{\mathbf{x}} / \mathrm{SO}_{2} \text { EMISSIONS } \\
\text { CONTROL SYSTEM } \\
\text { Public Service Company of Colorado }\end{array}$ & CCT-III & 100 & $13.7(50 \%)$ & $13.7(50 \%)$ & 27.4 \\
\hline $\begin{array}{l}\text { ADVANCED FLUE GAS DESULFURIZATION } \\
\text { DEMONSTRATION PROJECT } \\
\text { Pure Air on the Lake, L.P. }\end{array}$ & CCT-II & 528 & $63.4(42 \%)$ & $87.0(58 \%)$ & 150.5 \\
\hline $\begin{array}{l}\text { DEMONSTRATION OF ADVANCED } \\
\text { COMBUSTION TECHNIQUES FOR A WALL- } \\
\text { FIRED BOILER } \\
\text { Southern Company Services, Inc. }\end{array}$ & CCT-II & 500 & $6.6(45 \%)$ & $8.3(55 \%)$ & 14.7 \\
\hline $\begin{array}{l}\text { DEMONSTRATION OF INNOVATIVE } \\
\text { APPLICATIONS OF TECHNOLOGY FOR THE } \\
\text { CT-121 FGD PROCESS } \\
\text { Southern Company Services, Inc. }\end{array}$ & CCT-II & 100 & $17.5(49 \%)$ & $18.3(51 \%)$ & 35.8 \\
\hline $\begin{array}{l}\text { DEMONSTRATION OF SELECTIVE CATALYTIC } \\
\text { REDUCTION TECHNOLOGY FOR THE } \\
\text { CONTROL OF NO }{ }_{x} \text { EMISSIONS FROM HIGH- } \\
\text { SULFUR COAL-FIRED BOILERS } \\
\text { Southern Company Services, Inc. }\end{array}$ & CCT-II & 8.7 & $7.5(48 \%)$ & $8.0(52 \%)$ & 15.6 \\
\hline
\end{tabular}




\begin{tabular}{|c|c|c|c|c|c|}
\hline $\begin{array}{l}\text { PROJECT } \\
\text { Sponsor }\end{array}$ & Solicitation & $\begin{array}{l}\text { MW Scale of } \\
\text { Project }\end{array}$ & $\begin{array}{l}\text { DOE Obligation } \\
\text { (millions of } \\
\text { dollars) }\end{array}$ & $\begin{array}{l}\text { Private Obligation } \\
\text { (millions of dollars) }\end{array}$ & $\begin{array}{l}\text { Total Provisional } \\
\text { Cost Estimate } \\
\text { (millions of dollars) }\end{array}$ \\
\hline $\begin{array}{l}\text { 180-MWe DEMONSTRATION OF ADVANCED } \\
\text { TANGENTIALLY FIRED COMBUSTION } \\
\text { TECHNIQUES FOR REDUCTION OF NO }{ }_{x} \\
\text { EMISSIONS FROM COAL-FIRED BOILERS } \\
\text { Southern Company Services, Inc. }\end{array}$ & CCT-II & 180 & $4.4(49 \%)$ & $4.6(51 \%)$ & 9.0 \\
\hline $\begin{array}{l}\text { MICRONIZED COAL REBURNING } \\
\text { DEMONSTRATION FOR NO } \text { CONTROL ON A }_{x} \\
\text { 175-MWe WALL-FIRED UNIT } \\
\text { Tennessee Valley Authority }\end{array}$ & CCT-IV & 175 & $3.5(48 \%)$ & $3.8(52 \%)$ & 7.3 \\
\hline $\begin{array}{l}\text { DEVELOPMENT OF THE COAL QUALITY } \\
\text { EXPERT } \\
\text { ABB Combustion Engineering, Inc., and CQ, Inc. }\end{array}$ & CCT-I & $250-880$ & $10.9(50 \%)$ & $10.9(50 \%)$ & 21.7 \\
\hline $\begin{array}{l}\text { COMMERCIAL-SCALE DEMONSTRATION OF } \\
\text { LIQUID-PHASE METHANOL (LPMEOH }{ }^{\mathrm{M}} \text { ) } \\
\text { PROCESS } \\
\text { Air Products and Chemicals, Inc. }\end{array}$ & CCT-III & $\begin{array}{l}150 \text { tons/day of } \\
\text { methanol }\end{array}$ & $92.7(43 \%)$ & $121(57 \%)$ & 213.7 \\
\hline $\begin{array}{l}\text { SELF-SCRUBBING COAL }{ }^{\mathrm{TM}} \text { : AN INTEGRATED } \\
\text { APPROACH TO CLEAN AIR } \\
\text { Custom Coals International }\end{array}$ & CCT-IV & 350 tons/hour & $38(47 \%)$ & $43.7(53 \%)$ & 81.7 \\
\hline $\begin{array}{l}\text { ENCOAL MILD COAL GASIFICATION PROJECT } \\
\text { ENCOAL Corporation }\end{array}$ & CCT-III & $\begin{array}{l}1,000 \text { tons/day } \\
\text { of } \\
\text { subbituminous } \\
\text { coal feed }\end{array}$ & $36.3(50 \%)$ & $36.3(50 \%)$ & 72.6 \\
\hline $\begin{array}{l}\text { ADVANCED COAL CONVERSION PROCESS } \\
\text { DEMONSTRATION } \\
\text { Rosebud SynCoal Partnership }\end{array}$ & CCT-I & 45 tons/hour & $34.5(50 \%)$ & $34.5(50 \%)$ & 69.0 \\
\hline $\begin{array}{l}\text { BLAST FURNACE GRANULATED COAL } \\
\text { INJECTION SYSTEM DEMONSTRATION } \\
\text { PROJECT } \\
\text { Bethlehem Steel Corporation }\end{array}$ & CCT-III & $\begin{array}{l}7,000 \text { net } \\
\text { tons } / \text { day of hot } \\
\text { metal }\end{array}$ & $31.2(22 \%)$ & $112.5(78 \%)$ & 143.8 \\
\hline $\begin{array}{l}\text { INNOVATIVE COKE OVEN GAS CLEANING } \\
\text { SYSTEM FOR RETROFIT APPLICATIONS } \\
\text { Bethlehem Steel Corporation }\end{array}$ & CCT-II & $\begin{array}{c}74 \text { mil std } \\
\mathrm{ft}^{3} / \text { day of COG }\end{array}$ & $13.5(30 \%)$ & $31.7(70 \%)$ & 45.2 \\
\hline
\end{tabular}




\begin{tabular}{|c|c|c|c|c|c|}
\hline $\begin{array}{l}\text { PROJECT } \\
\text { Sponsor }\end{array}$ & Solicitation & $\begin{array}{l}\text { MW Scale of } \\
\text { Project }\end{array}$ & $\begin{array}{l}\text { DOE Obligation } \\
\text { (millions of } \\
\text { dollars) }\end{array}$ & $\begin{array}{l}\text { Private Obligation } \\
\text { (millions of dollars) }\end{array}$ & $\begin{array}{l}\text { Total Provisional } \\
\text { Cost Estimate } \\
\text { (millions of dollars) }\end{array}$ \\
\hline $\begin{array}{l}\text { ADVANCED CYCLONE COMBUSTOR WITH } \\
\text { NNTERNAL SULFUR, NITROGEN, AND ASH } \\
\text { CONTROL } \\
\text { Coal Tech Corporation }\end{array}$ & CCT-I & $23 \mathrm{mil} \mathrm{Btu} / \mathrm{hour}$ & $0.5(50 \%)$ & $0.5(50 \%)$ & $1.0^{\mathrm{b}}$ Completed \\
\hline $\begin{array}{l}\text { CEMENT KILN FLUE GAS RECOVERY } \\
\text { SCRUBBER } \\
\text { Passamaquoddy Tribe }\end{array}$ & CCT-II & $\begin{array}{c}1,450 \text { tons/day } \\
\text { of cement; } \\
250,000 \mathrm{std} / \mathrm{ft}^{3} \\
\text { of kiln gas; up } \\
\text { to } 274 \text { tons/day } \\
\text { of coal }\end{array}$ & $6.0(36 \%)$ & $10.5(64 \%)$ & 16.5 \\
\hline $\begin{array}{l}\text { DEMONSTRATION OF PULSE COMBUSTION IN } \\
\text { AN APPLICATION FOR STEAM GASIFICATION } \\
\text { OF COAL } \\
\text { ThermoChem, Inc. }\end{array}$ & CCT-IV & $\begin{array}{c}161 \text { million } \\
\text { Btu/hour of } 325 \\
\text { Btu/std } \mathrm{ft}^{3} \\
\text { medium-Btu } \\
\text { fuel gas plus } \\
40,000 \mathrm{lb} / \mathrm{hr} \text { of } \\
\text { export steam }\end{array}$ & $18.7(50 \%)$ & $18.7(50 \%)$ & 37.3 \\
\hline $\begin{array}{l}\text { INTEGRATED IRON ORE REDUCTION-POWER } \\
\text { GENERATION } \\
\text { Centerior Energy Corporation }\end{array}$ & CCT-V & & & & \\
\hline $\begin{array}{l}\text { CLEAN COAL DIESEL ENGINE } \\
\text { Easton Utility/A.D. Little }\end{array}$ & CCT-V & & & & \\
\hline
\end{tabular}

"Projects are ongoing or pending final approval (CCT-V) unless otherwise stated.

${ }^{b}$ Completed projects; figures represent total cost.

Source: DOE (1994). 


\section{REFERENCE}

DOE. 1994. Clean Coal Technology Demonstration Program: Program Update 1993. U.S. Department of Energy, DOE/FE-0299P. Washington, D.C.: DOE. 


\section{Appendix F}

\section{Committee Meetings and Activities}

1. Committee Meeting, November 22-23, 1993, Washington, D.C. The following presentations were made to the committee:

Department of Energy Introduction and Expectations for the Study

Doug Uthus, Director, Coal Combustion, Coal Preparation, and Control Systems, U.S. Department of Energy

Scenarios for Coal

Richard Dye, Manager, Fossil Fuel Utilization Program, U.S. Department of Energy

Overview of DOE Coal Program

Howard Feibus, Director, Office of Clean Coal Technology, U.S. Department of Energy

Summary of Advanced Power Systems Effort

Howard Feibus, Director, Office of Clean Coal Technology, U.S. Department of Energy

Summary of Advanced Fuel Systems Effort

Robert Hamilton, Acting Director, Office of Coal Conversion, U.S. Department of Energy

Contributing Research Under AR\&TD Program

Dave Beecy, Director, Office of Advanced Research, U.S. Department of Energy

DOE Perspective on EPACT 1992

Howard Feibus, Director, Office of Clean Coal Technology, U.S. Department of Energy 
2. Power Generation/Technology Subgroup Meeting, January 13-14, 1994, Washington, D.C.

The following presentations were made to the committee:

Projections of Utility Industry Needs

George Preston, Vice President, Generation and Storage, Electric Power Research Institute

Larry Joseph, Senior Program Manager, Clean Coal Technology Program, U.S. Department of Energy

Gary Styles, Manager, Special Projects, Southern Services Company

Donald Hafer, Manager, Cogeneration and Performance, American Electric Power Company, Inc.

Advanced Gas Turbines

Sandy Webb, Product Manager, Heat Engines, Morgantown Energy Technology Center

Hot Gas Cleanup

Randy Dellefield, Product Manager, Pressurized Fluidized-Bed Combustion, Morgantown Energy Technology Center

Fuel Cell Development

Manville Mayfield, Product Manager, Fuel Cells, Morgantown Energy Technology Center

Low-Emission Boilers

Larry Ruth, Division Director, Coal Utilization, Pittsburgh Energy Technology Center

Assessment of the Role of Government in Clean Coal Technology

Larry Papay, Vice President and Manager of Research and Development, Bechtel Group, Inc.

Past, Present, and Future Commercialization Activities in the Office of Fossil Energy

Douglas Uthus, Director, Coal Combustion, Coal Preparation, and Control Systems, U.S. Department of Energy

Direct Liquefaction

Edgar Klunder, Project Coordinator, Direct Liquefaction, Pittsburgh Energy Technology Center 
Indirect Liquefaction

Gary Stiegel, Project Coordinator, Indirect Liquefaction, Pittsburgh Energy Technology Center

3. Strategy/Policy Subgroup Meeting, January 27-28, 1994, Washington, D.C.

The following presentations were made to the committee:

The DOE Fiscal Year 1995 Budget: DOE/Fossil Energy Strategic Planning Process

Jack Siegel, Acting Assistant Secretary, Office of Fossil Energy, U.S. Department of Energy

George Rudins, Acting Deputy Assistant Secretary for Coal Technology, U.S. Department of Energy

Jay Braitsch, Acting Director, Office of Planning and Environment, Office of Fossil Energy, U.S. Department of Energy

The Regulatory Environment for the Utility Industry

John Bachman, Associate Director, Office of Air Quality Planning and Standards, U.S. Environmental Protection Agency

An Alternative Energy Future

John Hemphill, Executive Director, Business Council/Alliance to Save Energy

Projections of Natural Gas Use and Price

William Burnett, Senior Vice President, Technology Development, Gas Research Institute

Costs of Greenhouse Gas Reductions

Jae Edmonds, Battelle Pacific Northwest Laboratories

The U.S. Coal Resource Base

Harold J. Gluskoter, U.S. Geological Survey

4. Committee Meeting, March 3-4, 1994, Washington, D.C.

5. Writing Group Meeting, April 21-22, 1994, Irvine, California

6. Committee Meeting, May 19-20, 1994, Washington, D.C. 


\section{Appendix G \\ Biographical Sketches of Committee Members}

John P. Longwell received his B.S. in mechanical engineering from the University of California, Berkeley, and his Sc.D. in chemical engineering from the Massachusetts Institute of Technology (MIT). Dr. Longwell spent 33 years with Exxon Research and Engineering Company, where he was engaged in research and research management activities in the petroleum, petrochemical, and propulsion areas. He subsequently joined MIT as Edward R. Gilliland Professor of Chemical Engineering and is currently professor emeritus in the Department of Chemical Engineering. His research interests include the utilization of fossil energy resources, fuels and combustion systems, and the ecology of Idaho rivers and lakes. Dr. Longwell is a member of the National Academy of Engineering.

Edward S. Rubin is the Alumni Professor of Environmental Engineering and Science at Carnegie Mellon University (CMU). He holds joint appointments in the Departments of Engineering and Public Policy and Mechanical Engineering and is director of CMU's Center for Energy and Environmental Studies. He earned a B.E. in mechanical engineering at the City College of New York and an M.S. and Ph.D. in mechanical engineering from Stanford University. His teaching and research interests at CMU are in the areas of environmental control, energy utilization, and technology-policy interactions, with a particular focus on coalbased systems. He has served as a member of technical and advisory committees to the U.S. Environmental Protection Agency and the National Academy of Sciences and is a past chairman of the Environmental Control Division of the American Society of Mechanical Engineers.

Morrel H. Cohen received his B.S. from Worcester Polytechnic Institute, his M.A. from Dartmouth College, and his Ph.D. in physics from the University of California, Berkeley. Dr. Cohen held positions at the University of Chicago and the James Franck Institute before joining Exxon Research and Engineering Company as senior science advisor in the corporate research laboratories. He has also held concurrent positions at the Universities of Cambridge and Amsterdam and Argonne National Laboratory. Dr. Cohen's areas of interest include the theoretical physics of condensed matter, developmental biology, and, energy policy. He is a member of the National Academy of Sciences.

A. Denny Ellerman obtained his A.B. in public and international affairs from Princeton University and his Ph.D. in political economy and government from Harvard University. Following service with the U.S. Marine Corps, Dr. Ellerman held positions with the U.S. 
Departments of Defense, State, and Energy and the Office of Management and Budget. Later he was executive vice president of the National Coal Association. Dr. Ellerman is currently executive director of the Center for Energy and Environmental Policy Research and senior lecturer at the Sloan School of Management at the Massachusetts Institute of Technology. His interests are primarily in energy economics and policy analysis.

Martha W. Gilliland earned her B.A. from Catawba College, North Carolina; her M.A. from Rice University; and her Ph.D. in environmental engineering and systems ecology from the University of Florida. She has held positions at the Universities of Oklahoma and NebraskaLincoln and was executive director of Energy Policy Studies, Inc. Dr. Gilliland is currently vice provost for academic affairs at the University of Arizona. Her research interests are in energy technologies, energy policy, and environmental science and policy.

Robert D. Hall received his B.S. in chemical engineering from the University of Illinois. He then joined Sinclair Research Laboratories as a design engineer before taking up a position with Amoco Chemical Company. Mr. Hall served as director of design and economics and director of process research for the Amoco Oil Company, manager of strategic planning for the Information Services Department, and manager of management systems and planning in the Corporate Research Department before assuming his current position as general manager of the Alternative Feedstock Development Department. He has extensive expertise in scientific and engineering aspects of the production of liquid fuels and chemicals from biomass, natural gas, coal, oil shale, tar sands, and organic waste products.

John W. Larsen earned his B.S. from Tufts University and his Ph.D. in chemistry from Purdue University. He was professor of chemistry at the University of Tennessee before joining Lehigh University, where he is currently professor of chemistry. His primary research interests are the organic chemistry and macromolecular structure of coal, coal conversion, and pyrolysis. Dr. Larsen is editor of the American Chemical Society journal, Energy and Fuels.

Peter T. Luckie received his B.S. in fuel engineering, his M.S. in mineral preparation, and his Ph.D. in mineral processing, all from the Pennsylvania State University. Dr. Luckie's industrial experience includes positions with Pitt-Consol Chemical Company, HRB-Singer, Inc., Kennedy Van Saun Corporation, and McNally Pittsburgh Corporation, where he was corporate director for research and development. He is currently associate dean for research in the College of Earth and Mineral Sciences and professor of mineral engineering at the Pennsylvania State University. His principal research interests are in comminution, liberation, solid-solid separation, and circuit analysis.

Maurice D. McIntosh received his B.S. in mechanical and nuclear engineering from North Carolina State University. He has 30 years of experience in the electric utility industry, primarily with Duke Power, where he is currently vice president of the Fossil/Hydro Generation Department. He has responsibility for the operation and maintenance of Duke Power's coal-fired and hydro stations and was previously manager of the McGuire Nuclear Station in North Carolina. 
George T. Preston obtained his B.S. from the California Institute of Technology and his Ph.D. from the University of California, Berkeley, both in chemical engineering. He was technical manager of resource recovery programs for Occidental Research Corporation before joining the Electric Power Research Institute (EPRI). His positions at EPRI have included that of director of environmental control systems and director of fossil power plants. He is currently vice president of generation.

Eric H. Reichl received his M.S. in chemical engineering from the Technical University of Vienna. He has spent his entire professional career in the coal, gas, and oil industries, including 24 years with the R\&D Division of Consolidation Coal Company. He is the former president of Conoco Coal Development Company. Mr. Reichl chaired the U.S. Department of Energy's Research Advisory Board panel, which issued a 1985 report entitled Clean Coal Use Technologies, and served briefly on the board of directors of the Synthetic Fuels Corporation. $\mathrm{He}$ has extensive expertise in coal conversion and associated environmental issues. $\mathrm{He}$ is a member of the National Academy of Engineering.

Larry D. Woodfork earned his B.S. and A.M. degrees in geology from Indiana University. He has conducted extensive geological fieldwork and has been involved in exploration geology throughout the United States for the California Company (now Chevron), the Indiana Geological Survey, and Humble Oil and Refining Company (now Exxon). Mr. Woodfork is currently director and state geologist for the West Virginia Geological and Economic Survey and holds adjunct appointments as professor of geology and petroleum engineering at West Virginia University. His current research interests include the geology of fossil fuels and environmental geology. Mr. Woodfork is an honorary member of the American Association of Petroleum Geologists and a past president of the American Institute of Professional Geologists.

John M. Wootten received his B.S. in mechanical engineering and his M.S. in civil engineering, both from the University of Missouri. He has spent most of his professional career with Peabody Holding Company, Inc., the largest producer and marketer of coal in the United States. His positions at Peabody and its subsidiaries have included that of director of environmental services, director of research and technology, vice president for engineering and operations services, and president of Coal Services Corporation (COALSERV). Mr. Wootten is currently vice president of engineering and environmental services for Peabody Holding Company, Inc. His areas of expertise include the environmental and combustion aspects of coal utilization, clean coal technologies, and environmental control technologies for coal combustion. 


\section{Glossary and Conventions}

\section{Cost of Coal Conversion Processes}

The cost of producing electricity or clean gaseous and liquid fuels from coal is highly dependent on the level of capital investment and, therefore, on the return required by investors. This return depends on both the prime rate, which reflects the anticipated effects of inflation and the desire of the Federal Reserve Bank to control inflation, and the investors' assessment of risk.

The electric utility industry, with its relatively predictable selling prices for electricity and stable production costs, can attract capital at a lower prime rate than, for example, the oil industry, where future product and feedstock prices are much less certain. Major investments are frequently split between a component with relatively assured, but lower, return and a higherreturn component that will incur a larger risk. In the utility industry, a substantially larger component of low-risk borrowed money is more common than in the petroleum industry, where 100 percent equity financing has been more commonly practiced. Hence, the term "utility financing" is frequently used to describe highly leveraged investments, whereas "petroleum financing" describes investments with the smaller component of borrowed money generally employed in that industry.

The costs presented by the U.S. Department of Energy (DOE) and used in this report are based on leveraged financing. Key assumptions are summarized below. ${ }^{1}$ It has also been assumed that sufficient plants have been built to reach a stable cost (nth plant costs; see Chapter 8).

Key assumptions for capital cost estimation:

Bank interest rate (percent) 8

Percent equity

Percent internal rate of return 15

Years of construction 4

Years of operation 25

Depreciation, years 10

'DOE, 1993, Direct Coal Liquefaction Baseline Design and System Analysis: Final Report on Baseline and Improved Baseline, Executive Summary, prepared for the U.S. Department of Energy, Pittsburgh Energy Technology Center, under contract no. DEAC22 90PC89857, DOE, Pittsburgh, Pennsylvania. 


$\begin{array}{lr}\text { Maintenance, percent initial } & 1 \\ \quad \text { capital } & 10 \\ \text { Working capital, percent revenue } & 50 \\ \text { Working capital, percent liquid } & 5 \\ \text { Owner's cost, percent initial } & 34 \\ \quad \text { capital, first-year operation } & 3 \\ \text { Federal income tax rate, percent } & \\ \text { General inflation, percent } & 3 \\ \text { Raw material price escalation, } & 0 \\ \quad \text { percent (same as general inflation) } & \end{array}$

General inflation of 3 percent per year was applied to all costs and selling prices. As mentioned above, an assumed rate of inflation was included in the investment required by investors.

\section{Economic Conventions}

Throughout this report, all costs, prices, and so forth, are given in constant 1992 dollars unless otherwise specified. A Gross Domestic Product Implicit Price Deflator ${ }^{2}$ has been used to adjust current dollars to 1992 dollar figures. An exception is DOE budget data, which are quoted in current dollars.

\section{Thermal Efficiency}

Throughout this report all thermal efficiency figures are based on the higher heating value (HHV) of fuel, which is the convention most widely used in the United States for coal-based systems. HHV credits the fuel with the heat of vaporization of water formed in the combustion reaction; that is, water is assumed to exist in the liquid phase after combustion. This is consistent with the standard thermodynamic conditions of $25^{\circ} \mathrm{C}\left(77^{\circ} \mathrm{F}\right)$ and 1 atmospheric pressure used to calculate the heat of formation or reaction of any chemical compound (recall that "heating value" is simply the name commonly used for the heat of reaction of a hydrocarbon used as fuel).

In parts of Europe and elsewhere, however, the lower heating value (LHV) is commonly used in reporting thermal efficiencies. In the United States LHV is commonly used to quote efficiencies based on natural gas as a fuel. The LHV assumes that water formed in combustion remains in a vapor state, as in actual combustion systems that discharge flue gases at temperatures of several hundred degrees. Thus, the energy potentially recoverable by condensing water in the flue gas is assumed to be unavailable and not credited to the fuel. Since the LHV

2 EIA, 1994, Annual Energy Review 1993, Energy Information Administration, U.S. Department of Energy, DOE/EIA-0384(93), DOE, Washington, D.C. 
assumes that fuel delivers less energy input than the HHV, any thermodynamic efficiency, $\underline{\mathrm{E}}$, based on LHV will be higher than one based on HHV in simple inverse proportion; that is, $\mathrm{E}_{\mathrm{LHV}} / \mathrm{E}_{\mathrm{HHV}}=\mathrm{HHV} / \mathrm{LHV}$.

The numerical difference between LHV and HHV depends on the fuel. The difference is smallest for coal (where LHV is roughly 4 percent less than HHV) and greatest for natural gas (where LHV is about 10 percent lower). Accordingly, a power plant efficiency of 40 percent based on HHV would be reported as 42 percent based on LHV using coal and about 44 percent based on LHV using natural gas.

\section{ABB Asea Brown Boveri}

AFBC Atmospheric fluidized bed combustion

Anthracite Highest rank of economically useable coal, with a heating value of $15,000 \mathrm{Btu}$ per pound, carbon content of 86 to 97 percent, and moisture content of less than 15 percent

APC Advanced pulverized coal

APS Advanced power system

AR\&ET Advanced research and environmental technology

AR\&TD Advanced research and technology development

ATS Advanced turbine system

Baseload Baseload is the minimum amount of power required during a specified period at a steady state.

bbl Barrel

Bituminous coal Type of coal most commonly used for electric power generation, with a heating value of 10,500 to 15,000 Btu per pound, carbon content of 45 to 86 percent, and moisture content of less than 20 percent

Btu British thermal unit

CAAA Clean Air Act Amendments

CCT Clean coal technology

CCTC Clean Coal Technology Coalition

CE

$\mathrm{CH}_{4} \quad$ Methane

Cl $\cdot$ Chlorine

CO Carbon monoxide

$\mathrm{CO}_{2} \quad$ Carbon dioxide

COM Coal-oil mixture

CWM Coal-water mixture

CWS Coal-water slurry

DOE U.S. Department of Energy

DRB Demonstrated reserve base

DSM Demand-side management; DSM programs are instituted by utilities, such as rebates to customers for installation of energy-efficient appliances or reduced rates 
for nonpeak-load use of electricity, to encourage customers to reduce electricity consumption overall or at certain periods.

ECU European currency unit

EFCC Externally fired combined-cycle

EIA Energy Information Administration

EMF Electromagnetic fields

EPA U.S. Environmental Protection Agency

EPACT Energy Policy Act of 1992

EPRI Electric Power Research Institute

ESP Electrostatic precipitator

EU European Union

FBC Fluidized-bed combustion

FE Fossil energy

FGD Flue gas desulfurization

F-T Fischer-Tropsch process; catalytic conversion of synthesis gas into a range of hydrocarbons.

GDP Gross domestic product

Greenhouse gases Gases, such as water vapor, carbon dioxide, tropospheric ozone, nitrous oxide, and methane, that are transparent to solar radiation but opaque to longwavelength radiation; their action is similar to that of glass in a greenhouse.

GRI Gas Research Institute

GW Gigawatt (10 $10^{9}$ Watts)

GWh Gigawatt-hour

$\mathrm{H}_{2} \quad$ Hydrogen

Hg Mercury

HHV Higher heating value

HIPPS High-performance power system

IFC Indirectly fired cycle

IGCC Integrated gasification combined-cycle; IGCC power generation systems replace the traditional coal combustor with a gasifier and gas turbine.

IGFC Integrated gasification fuel cell

KRW Kellogg-Rust-Westinghouse

kW Kilowatt

kWh Kilowatt-hour

LEBS Low-emission boiler system

LHV Lower heating value

Life extension Life extension is achieved by maintaining or improving the operating status of an electric power plant within acceptable levels of availability and efficiency, beyond the originally anticipated retirement date.

Lignite Type of coal with a heating value of 4,000 to 8,300 Btu per pound, a carbon content of 25 to 35 percent, and moisture content up to 45 percent.

LNG Liquefied natural gas

Mcf Thousand cubic feet

MCFC Molten carbonate fuel cell 
METC Morgantown Energy Technology Center

MHD Magnetohydrodynamics

Mild gasification See Pyrolysis

MMBtu Million $\left(10^{6}\right)$ Btu

MW Megawatt (10 Watts)

MWe Megawatt electric

MWt Megawatt thermal

NCA National Coal Association

NCC National Coal Council

$\mathrm{NH}_{3} \quad$ Ammonia

$\mathrm{NO}_{2} \quad$ Nitrogen dioxide

$\mathrm{NO}_{\mathrm{x}} \quad$ Oxides of nitrogen; a mix of nitrous oxide (NO) and nitrogen dioxide $\left(\mathrm{NO}_{2}\right)$

NSPS New Source Performance Standards

NUG Non-utility generator

$\mathrm{O}_{3} \quad$ Ozone

OECD Organization for Economic Cooperation and Development

OPEC Organization of Petroleum Exporting Countries

PAFC Phosphoric acid fuel cell

PC Pulverized coal

Peak load Peak load (usually in reference to electrical load) is the maximum load during a specified period of time.

PETC Pittsburgh Energy Technology Center

PFBC Pressurized fluidized-bed combustion

ppm Parts per million

psi (or psig) Pounds per square inch (psig indicates gauge pressure, that is, pressure above atmospheric pressure)

PURPA Public Utility Regulatory Policy Act of 1979

Pyrolysis Thermal decomposition of a chemical compound or mixture of chemical compounds.

quad Quadrillion $\left(10^{15}\right)$ Btu

Rank Variety of coal; the higher the rank of coal, the greater its carbon content and heating value.

RD\&D Research, development and demonstration

RDD\&C Research, development, demonstration and commercialization

Repowering Repowering is achieved by investments made in a plant to substantially increase its generating capability, to change generating fuels, or to install a more efficient generating technology at the plant site.

$\mathbf{R O}_{\mathbf{x}} \quad$ Particulate matter

Sasol South African Coal, Oil, and Gas Corporation; coal conversion plant in operation at Sasolburg; coal is gasified by the Lurgi process and then converted to liquid hydrocarbons through the Fisher-Tropsch process.

SCCWS Super clean cold water slurry

SCR Selective catalytic reduction; post-combustion $\mathrm{NO}_{\mathrm{x}}$ control with the use of catalysts. 
SNG Synthetic natural gas

$\mathrm{SNO}_{\mathrm{x}} \quad$ Combined $\mathrm{SO}_{2}$ and $\mathrm{NO}_{\mathrm{x}}$ catalytic advanced flue gas cleanup

SOFC Solid oxide fuel cell

$\mathrm{SO}_{\mathbf{x}} \quad$ Sulfur oxide

$\mathrm{SO}_{2} \quad$ Sulfur dioxide

Synthesis gas Mixture of carbon monoxide and hydrogen and other liquid and gaseous products

Subbituminous coal Coal with a heating value of 8,300 to 11,500 Btu per pound, a carbon content of 35 to 45 percent, and a moisture content of 20 to 30 percent.

Synthetic Fuels Corporation Organization established by the Energy Security Act of 1980 to facilitate the development of domestic nonconventional energy resources.

TBC Thermal barrier coatings

Tcf Trillion $\left(10^{12}\right)$ cubic feet

$\mathrm{UF}_{6} \quad$ Uranium Hexafluoride

UNDEERC University of North Dakota Energy and Environmental Research Center

VOC Volatile organic compounds 